\title{
Acoustic Doppler Current Profiler Measurements in the Tailrace at John Day Dam
}

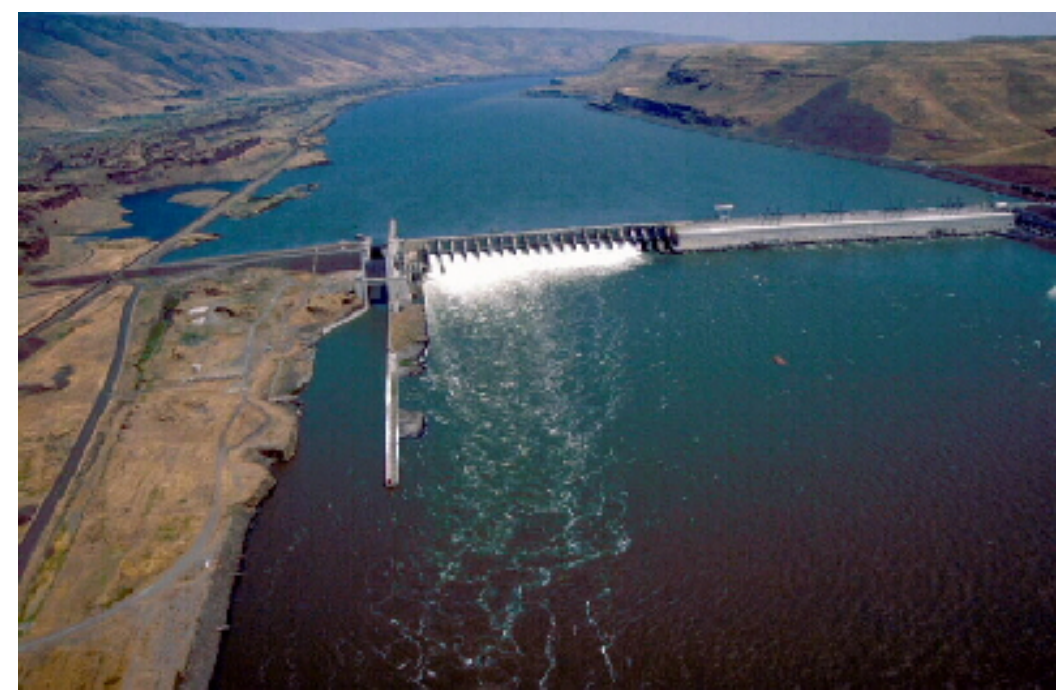

C.B. Cook

B. Dibrani

J.A. Serkowski

M.C. Richmond

P.S. Titzler

G.W. Dennis

FINAL REPORT

January 2006

Prepared for the U.S. Army Corps of Engineers

Portland District, Portland, Oregon

Under a Related Services Agreement with the U.S. Department of Energy

Contract DE-AC05-76RL01830

\section{Pacific Northwest}

National Laboratory

Operated by Battelle for the

U.S. Department of Energy 


\title{
DISCLAIMER
}

This report was prepared as an account of work sponsored by an agency of the United States Government. Neither the United States Government nor any agency thereof, nor Battelle Memorial Institute, nor any of their employees, makes any warranty, express or implied, or assumes any legal liability or responsibility for the accuracy, completeness, or usefulness of any information, apparatus, product, or process disclosed, or represents that its use would not infringe privately owned rights. Reference herein to any specific commercial product, process, or service by trade name, trademark, manufacturer, or otherwise does not necessarily constitute or imply its endorsement, recommendation, or favoring by the United States Government or any agency thereof, or Battelle Memorial Institute. The views and opinions of authors expressed herein do not necessarily state or reflect those of the United States Government or any agency thereof.

\author{
PACIFIC NORTHWEST NATIONAL LABORATORY \\ operated by \\ BATTELLE \\ for the \\ UNITED STATES DEPARTMENT OF ENERGY
}

under Contract DE-AC05-76RL01830

Printed in the United States of America

\author{
Available to DOE and DOE contactors from the \\ Office of Scientific and Technical Information, \\ P.O. Box 62, Oak Ridge, TN 37831-0062; \\ ph: (865) 576-8401 \\ fax: (865) 576-5728 \\ email: reports@adonis.osti.gov
}

\footnotetext{
Available to the public from the National Technical Information Service, U.S. Department of Commerce, 5285 Port Royal Rd., Springfield, VA 22161

ph: (800) 553-6847

fax: (703) 605-6900

email: orders@ntis.fedworld.gov

online ordering: http://www.ntis.gov/ordering.htm
}

This document was printed on recycled paper.

$(9 / 2003)$ 


\section{Acoustic Doppler Current Profiler Measurements in the Tailrace at John Day Dam}
C.B. Cook
B. Dibrani
J.A. Serkowski
M.C. Richmond
P.S. Titzler
G.W. Dennis

FINAL REPORT

January 2006

Prepared for the U.S. Army Corps of Engineers

Portland District, Portland, Oregon

Under a Related Services Agreement

with the U.S. Department of Energy

Contract DE-AC05-76RL01830

Richland, Washington 99352 


\section{Summary}

Acoustic Doppler current profilers (ADCPs) were used to measure water velocities in the tailrace at John Day Dam over a two-week period in February 2005. Data were collected by the Pacific Northwest National Laboratory for the Hydraulic Design Section, Portland District, U.S. Army Corps of Engineers (USACE). To address issues relating to the John Day Dam tailrace, the USACE has funded development of both computational fluid dynamics (CFD) and physical models of tailrace conditions. Because these models are representations of actual tailrace conditions, they need to be calibrated, verified, and validated against actual prototype data. The objective of this project was therefore to collect field measurements of water velocities in the near-field draft tube exit zone as well as the far-field tailrace to be used for improving these models.

Field data were collected during the project using five separate ADCPs. Mobile ADCP data were collected using two ADCPs mounted on two separate boats. Data were collected by either holding the boat on-station at predefined locations for approximately 10 minutes or in moving transect mode when the boat would move over large distances during the data collection. On-station measurement locations were prioritized before data collection began. However, some latitude was taken during the moving transect data collection based on observed hydraulic phenomena.

Results from the mobile ADCP survey indicated a complex hydrodynamic flow field in the tailrace downstream of John Day Dam. A large gyre was noted between the skeleton section of the powerhouse and nonspilling portion of the spillway. Downstream of the spillway, the spillway flow is constrained against the navigation lock guide wall, and large velocities were noted in this region. Downstream of the guide wall, velocities decreased as the spillway jet dispersed. Near the tailrace island, the flow split was measured to be approximately equal on Day 2 (25.4 kcfs spillway/123 kcfs total). However, approximately $60 \%$ of the flow passed along the south shore of the island on Day 1 (15.0 kcfs spillway/150 kcfs total). At a distance of 9,000 ft downstream of the dam, flows had equalized laterally and were generally uniform over the cross section.

The collection of water velocities near the draft tube exit of an operating turbine unit is not routine, and equipment capable of measuring 3D water velocities in these zones is at the forefront of hydraulic measurement technology. Although the feasibility of measuring 1D water velocity magnitudes has been previously demonstrated by the authors, the feasibility of resolving 3D water velocity vectors given the heterogeneity of the flow field was unknown before this study's data were collected. Both the 1D and 3D data were collected by deploying three ADCPs on dual-axis rotators directly above the draft tube exit of Turbine Unit 16. These instruments collected 1D data during both the mobile reconnaissance campaign and a later one-week period with zero spillway discharge. During the zero spillway discharge period, Turbine Unit 16 was operated over a range of discharges. Approximately 12 hours of $1 \mathrm{D}$ velocity data were collected at low (12 kcfs), middle (16.2 kcfs), and high (19.2 kcfs) turbine discharges. The 1D dataset indicates large differences in flow patterns and root mean square (RMS) velocity fluctuations among the various discharge levels.

Results from this project show that it is technically feasible to measure 3D water velocities directly downstream of an operating turbine unit using a narrow beam-swath (i.e., 6-degree) ADCP. Data 
products from these 3D velocity data include a measurement of the draft tube barrel flow distribution (a.k.a., the flow split), directional changes and the general decay of velocity as flow exits the draft tube and enters the tailrace, and a relative measure of the homogeneity of the flow field.

Several specific recommendations are offered for future studies that may involve similar measurement technology. These are 1) on/off studies of adjacent turbine units to better understand how cross-flow affects turbine exit conditions; 2) improve turbine blocking so that turbine settings do not change during the ADCP measurements; 3) powerhouse ADCPs should be deployed inline with dividing wall/pier centerlines; 4) continued use of the narrow beam-swath ADCP because of the added value gained by converting the $1 \mathrm{D}$ velocities into $3 \mathrm{D}$ velocity vectors, and collaborate with Teledyne $\mathrm{RD}$ Instruments, Inc. to improve the narrow-beam ADCP sampling rate and the ability to disable a beam via direct commands. 


\section{Acknowledgments}

We sincerely acknowledge the cooperation, assistance, and dedication of the following persons during this study:

- U.S. Army Corps of Engineers, Portland District

- Sean Askelson (Project Coordinator)

- Laurie Ebner

- Don Hibbs

- Nathan Higa

- Kyle McCune

- Miroslaw Zyndol

- Pacific Northwest National Laboratory

- Andrea Currie (editor)

- Robert Johnson (technical review)

- John Stephenson

- Rose Urbina (text processing)

- Shon Zimmerman

- Advanced American Diving Service, Inc. 


\section{Abbreviations}

\begin{tabular}{|c|c|}
\hline $1 \mathrm{D}$ & one-dimensional \\
\hline $3 \mathrm{D}$ & three-dimensional \\
\hline $\mathrm{ADCP}$ & acoustic Doppler current profiler \\
\hline a.k.a. & also known as \\
\hline${ }^{\circ} \mathrm{C}$ & degrees Celsius \\
\hline $\mathrm{CD}$ & compact disk \\
\hline CFD & computational fluid dynamics \\
\hline $\mathrm{cm}$ & centimeters \\
\hline $\mathrm{cfs}$ & cubic feet per second $\left(\mathrm{ft}^{3} / \mathrm{s} ; 0.0283 \mathrm{~m}^{3} / \mathrm{s}\right)$ \\
\hline DGPS & differential global positioning system \\
\hline $\mathrm{E}$ & east \\
\hline e.g. & (exempli gratia) for example \\
\hline et al. & (et alii) and others \\
\hline etc. & (et cetera) and so forth \\
\hline $\mathrm{ft}$ & feet \\
\hline GDACS & Generic Data Acquisition and Control System \\
\hline $\mathrm{hr}$ & hours \\
\hline i.e. & (id est) that is \\
\hline kcfs & 1000 cubic feet per second \\
\hline $\mathrm{kHz}$ & kilohertz \\
\hline $\mathrm{m}$ & meters \\
\hline $\mathrm{mi}$ & miles \\
\hline MW & megawatts \\
\hline $\mathrm{N}$ & north \\
\hline PNNL & Pacific Northwest National Laboratory \\
\hline RDI & Teledyne RD Instruments, Inc. \\
\hline RMS & root mean square \\
\hline $\mathrm{R} / \mathrm{V}$ & research vessel \\
\hline $\mathrm{s}$ & second \\
\hline $\mathrm{S}$ & south \\
\hline USACE & U.S. Army Corps of Engineers \\
\hline
\end{tabular}




\section{Contents}

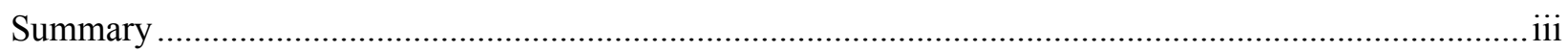

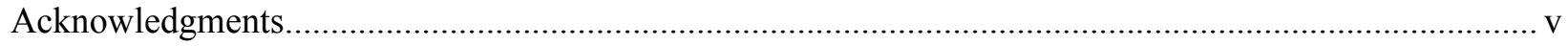

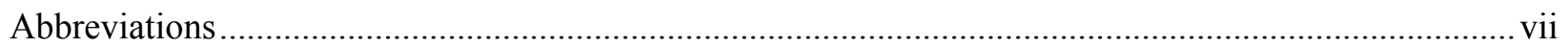

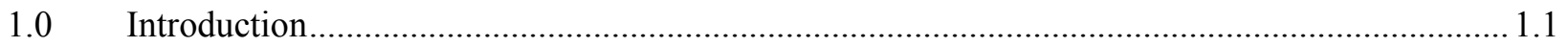

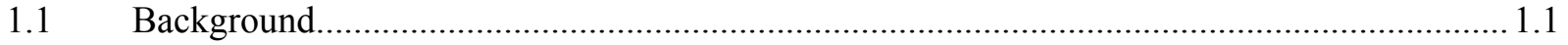

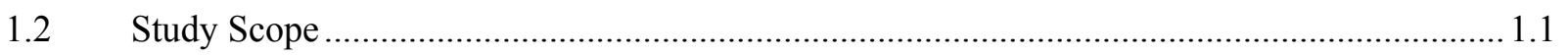

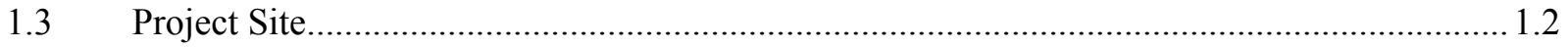

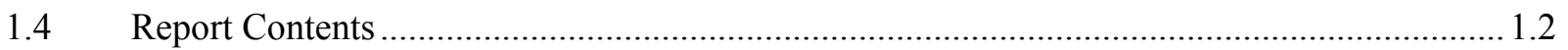

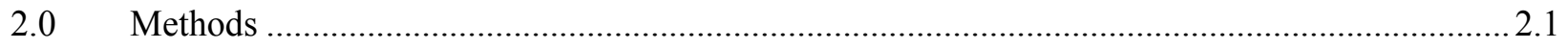

2.1 Broadband Acoustic Doppler Current Profilers .............................................................. 2.1

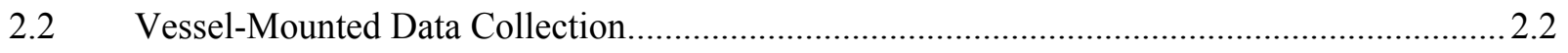

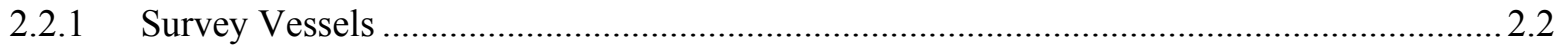

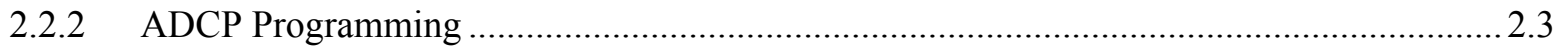

2.2.3 Gyrocompass and Differential Global Positioning System............................................. 2.3

2.2.4 Mobile Velocity Data Processing .................................................................................. 2.4

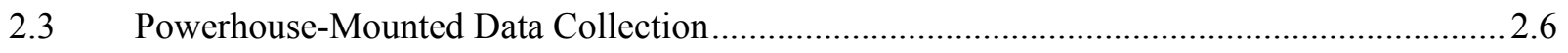

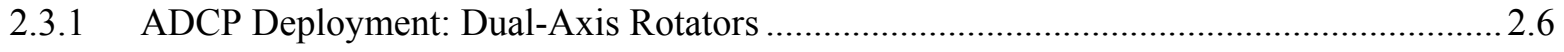

2.3.2 Powerhouse-Mounted ADCP Configuration............................................................... 2.7

2.3.3 Along-Beam Velocity Data: Sample Volume and Comparison to Physical Model

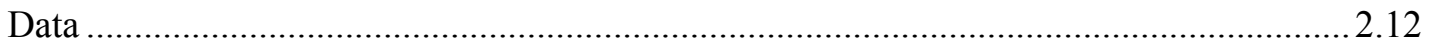

2.3.4 Along-Beam Velocity Filters: Root Mean Square Velocity Fluctuations and

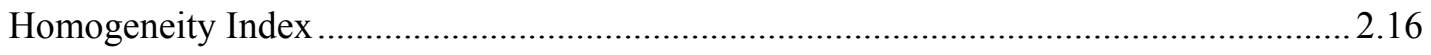

3.0 Acoustic Doppler Current Profiler Results …......................................................................... 3.1

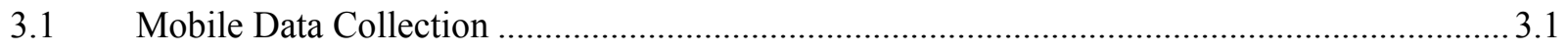

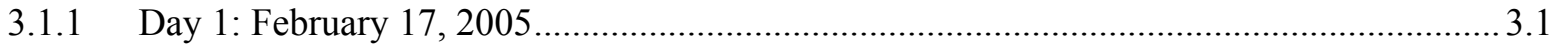

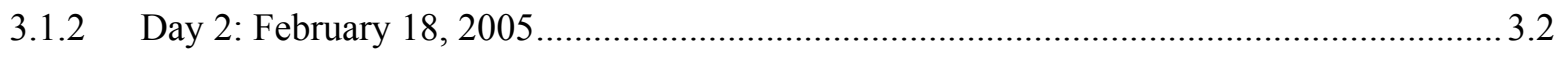

3.2 Powerhouse-Mounted Data Collection......................................................................... 3.3

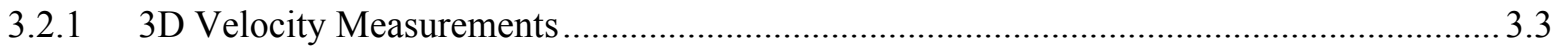

3.2.2 Feasibility of Discharge Measurements …................................................................. 3.6 
3.2.3 Decay of Velocity Magnitude with Distance Away from Draft Tube Exit...........................6

3.2.4 Along-Beam Velocities Near the Draft Tube Exit .......................................................... 3.12

3.2.5 Along-Beam Velocities Downstream of the Draft Tube Exit .......................................... 3.14

4.0 Bathymetry Measurements and Draft Tube Boil Locations .................................................... 4.1

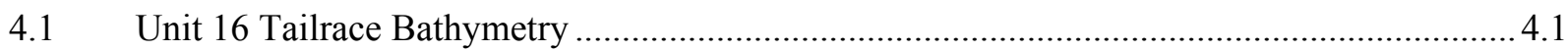

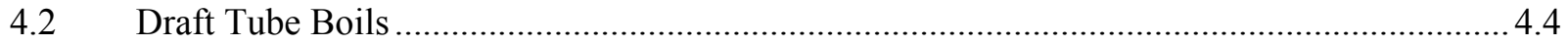

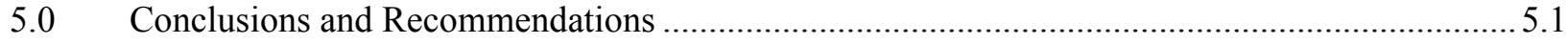

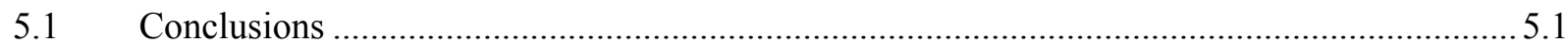

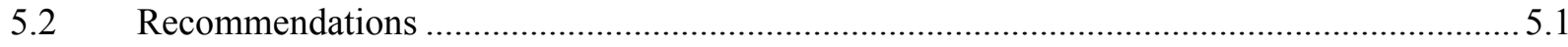

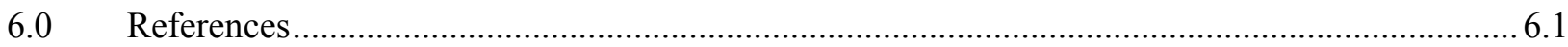

Appendix A - Boat-Mounted ADCP Measurements: Graphical Results ............................................. A.1

Appendix B - Graphical Views of Measured Three-Dimensional Water Velocity Vectors ...................... 1

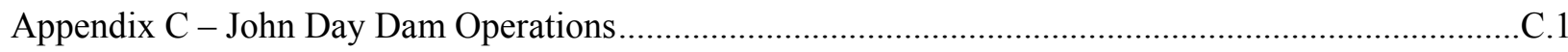

\section{Figures}

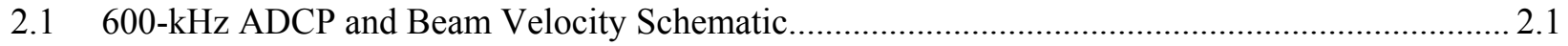

2.2 Research Vessels Sea Star and Strait Science ..................................................................... 2.2

2.3 Sample Cloud of Mobile Point Measurements ......................................................................... 2.5

2.4 ADCPs, Rotators, and Powerhouse Mounts ............................................................................... 2.6

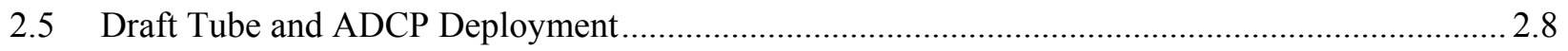

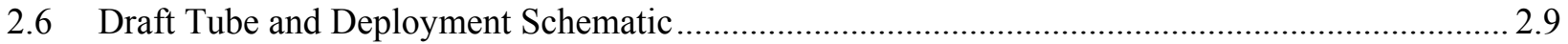

2.7 Center 300-kHz ADCP Oriented to Look Straight Down ....................................................... 2.10

2.8 Side-to-Side Coverage Swath of the Center 300-kHz ADCP Beams ......................................... 2.10

2.9 Left and Right 600-kHz ADCPs Looking Straight Down ...................................................... 2.11

2.10 Left and Right 600-kHz ADCPs Oriented to Look into the Draft Tubes .................................. 2.11

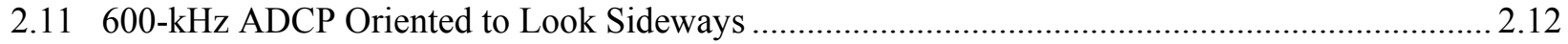

2.12 Graphical Representation of an ADCP Measured Along-Beam, or 1D, Velocity Magnitude....... 2.13

2.13 Graphical Comparison of Along-Beam ADCP Measurements to a Laser Doppler

Velocimeter Plane Measured in Lower Granite Dam Physical Model ........................................ 2.14

2.14 ADCP Mounted onto a Dual-Axis Rotator and Mount...............................................................2.15 
2.15 Scaled Comparison of Results from an Along-Beam ADCP and Projected LDV Measurement.

2.16 Along-Beam Velocity and Some of the Possible 3D Velocity Vectors That Contain Identical Along-Beam Direction Velocity Components ............................................................2.16

2.17 Sample Along-Beam Data Collected by ADCP1 ...................................................................... 2.17

2.18 Profiles of Mean Velocity and RMS Velocity Fluctuations Collected by ADCP1 on February 17, 2005

2.19 Profiles of 3D Water Velocity and Homogeneity Index for Data Collected by ADCP1 on February 17, 2005, at 14:46 hours

2.20 Side and Plan View of 3D Velocity Vectors for Data Collected by ADCP1 on February 17, 2005, for Approximately 10.5 Minutes Starting at 14:46 hours.

3.1 Collection of Velocity Vectors Measured by the South 6-Degree ADCP When the Reported Turbine Discharge Was Approximately $14.2 \mathrm{kcfs}$................................................................... 3.4

3.2 Three Cartesian Components of Velocity at the Draft Tube Exit ................................................. 3.5

3.3 Collection of Velocity Vectors Measured by the South 6-Degrees ADCP When the Reported Turbine Discharge Was Approximately $15.5 \mathrm{kcfs}$...................................................................... 3.7

3.4 Three Cartesian Components of Velocity at the Draft Tube Exit .............................................. 3.8

3.5 Measured X Velocity Component and the Resulting Discharge for Unit 16, Barrel A .................. 3.9

3.6 3D Velocity Vectors Exiting the Draft Tube …........................................................................ 3.10

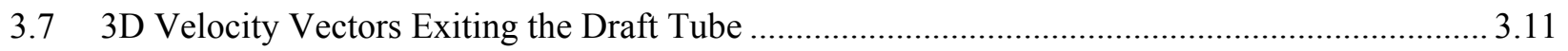

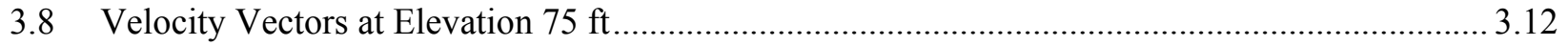

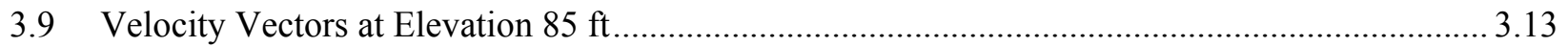

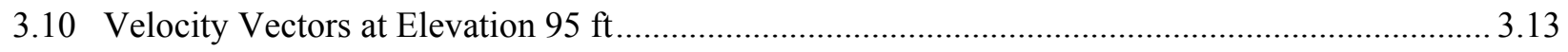

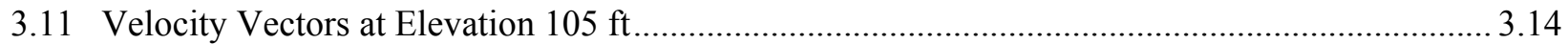

3.12 Measurement Points and the Interpolation Grid Used to Generate Along-Beam Velocity

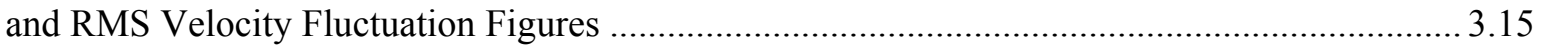

3.13 Along-Beam Velocity Magnitudes at Low, Medium, and High Discharge ................................ 3.16

3.14 Along-Beam RMS Velocity Fluctuations at Low, Medium, and High Discharge....................... 3.17

3.15 Measurement Points and the Interpolation Grid Used to Generate Along-Beam Velocity

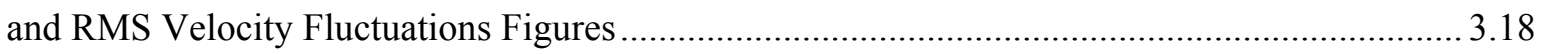

3.16 Along-Beam Velocity Magnitudes at Low, Medium, and High Discharge ................................ 3.19

3.17 Along-Beam RMS Velocity Fluctuations at Low, Medium, and High Discharge........................ 3.20 
4.1 Locations of ADCP Bathymetric Measurements versus the Hydrographic Survey Conducted for Portland District, USACE, and Used to Generate the CFD Model Bathymetry ....................... 4.2

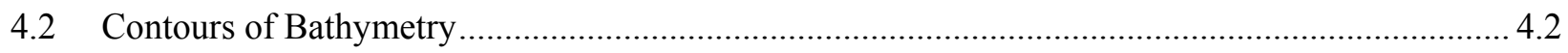

4.3 Plan View of the Tailrace Downstream of Unit 16 and Showing Cross-Section Lines.................. 4.3

4.4 Contours of Bathymetry Along the Cross-Section Lines Shown in Figure 4.3 ............................ 4.3

4.5 Surface Boils Downstream of the Draft Tube Exit ........................................................................ 4.4

4.6 Tailrace Schematic Showing Approximate Locations of Visible Surface Boils and Upwelling Zone

\section{Tables}

2.1 Along-Beam Velocity Uncertainties for Powerhouse-Mounted ADCPs ....................................2.12

3.1 GDACS Summary of Project Operations from 10:10 hours Until 16:00 hours on

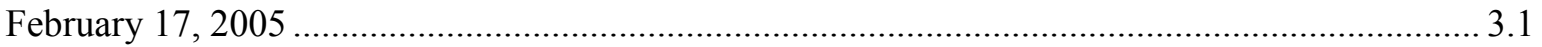

3.2 GDACS Summary of Project Operations from 10:20 hours Until 16:10 hours on February 18, 2005 


\subsection{Introduction}

This report presents results of a study designed to collect prototype water velocity datasets that can be used to validate numerical and physical models of the John Day Dam tailrace. This work was funded by the Hydraulic Design Section, Portland District, U.S. Army Corps of Engineers (USACE) and was conducted by a team of researchers from the Pacific Northwest National Laboratory (PNNL).

\subsection{Background}

Millions of juvenile anadromous fish pass through John Day Dam each year as they migrate down the Columbia River to the Pacific Ocean. Related USACE funded studies are investigating methods to improve passage through the dam and egress of the juveniles from the near-dam tailrace zone into the downstream river. Methods to improve passage include installing screens into the turbine intakes and improving hydraulic flow conditions in the draft tube. Methods to improve downstream egress include varying project operations to both speed transition of downstream migrants into the main river and to degrade predator habitat. In addition to juvenile salmon migration issues, studies are underway to also improve hydraulic conditions near the tailrace navigation lock entrance and guide wall during periods of spillway operation.

\subsection{Study Scope}

To address issues related to the John Day Dam tailrace, USACE has funded development of both computational fluid dynamics (CFD) and physical models of tailrace conditions. Because these models are representations of actual tailrace conditions, they need to be calibrated and validated against actual prototype data. The scope of this project was therefore to collect field measurements of water velocities in the near-field draft tube exit zone as well as the far-field tailrace to be used for improving these models.

Collection of 3D water velocities using acoustic Doppler current profilers (ADCPs) in the far-field tailrace zone is fairly routine and the approach has been well documented in the technical literature (Gordon 1989; Simpson 2001). However, the collection of water velocities near draft tube exits is not routine and equipment capable of measuring 3D water velocities in these zones are at the forefront of hydraulic measurement technology. Through previous studies at PNNL, the authors have shown that calibration and validation datasets for CFD and physical models can be obtained through the use of 1D velocity measurements collected by an ADCP. As part of this project's scope, PNNL was tasked with collecting 1D velocity datasets of the near-field draft tube exit zone. In addition, the feasibility of converting the $1 \mathrm{D}$ velocity measurements into meaningful 3D velocity vectors was also to be investigated by PNNL. If meaningful 3D data could be collected, PNNL was then to compute the draft tube barrel flow distribution (a.k.a., the flow split) and the near-field decay of water velocity as flow exits the draft tube barrel.

In addition to calibration and validation dataset for the near-field models, the project's scope was designed to also provide boundary condition data for far-field (a.k.a. general) physical and CFD models. Datasets collected for this purpose include 1) on-station and transecting mobile ADCP measurements near the draft tube exits; 2) longitudinal and lateral sweeps of spatially rectified 1D velocity measurements near the draft tube exit; and 3) if feasible, 3D velocity vector data collected near the draft tube exit. 
Finally, the USACE requested that PNNL provide any bathymetric information we could extract from the ADCP measurements near the draft tube exit. The USACE also requested that we measure the approximate location of surface boil phenomena near Unit 16's draft tube exits. Although these data were not part of the original scope of work, these values may be useful to the USACE for qualitatively checking the near-field and general models of the powerhouse tailrace zone.

\subsection{Project Site}

John Day Dam is the third in a series of dams encountered along the lower Columbia River as one moves upstream from the Pacific Ocean. It lies at river mile 216 on the Columbia and is approximately 100 miles east of Portland, Oregon. The USACE designed and constructed the dam, which was completed in 1971, and is responsible for its operation today. John Day Dam consists of 20 spillway bays controlled by 50 -ft-wide tainter gates, 16 Kaplan turbine units capable of producing a combined maximum of 2,160 MW, four skeleton bays for future hydroelectric generation expansion (bays 17 through 20), and a navigation lock with a total lift height of $113 \mathrm{ft}$ (USACE 2005).

\subsection{Report Contents}

Section 2 of this report describes the methods used to collect water velocities in the tailrace, including boat- and powerhouse-mounted ADCPs. Section 3 provides discussion of the results for both sampling methods. In Section 4, bathymetry measurements and draft tube boil data are presented and discussed. Conclusions and recommendations are listed in Section 5. References are in Section 6.

A series of appendixes provides supporting information: graphical results summary from the model ADCP survey (A); powerhouse mounted ADCP graphical results (B); and general project operations as reported by GDACS (C). 


\subsection{Methods}

\subsection{Broadband Acoustic Doppler Current Profilers}

Use of acoustic Doppler current profilers to collect water velocity profiles and river discharge has been widely documented in the technical literature since the 1980s (see Gordon [1989], Schott [1987], and Brumley et al. [1993]). ADCPs work by transmitting acoustic pulses (at either 600 or $1200 \mathrm{kHz}$ for this project) from each of four diverging acoustic transducers (see Figure 2.1). The transducers are spaced at 90-degree azimuth intervals from one another and at common vertical angles of either 6-degree (custom) or 20-degree. This transducer arrangement is known in the literature as a Janus configuration. After the pulse is emitted, the ADCP then listens to and processes returned echoes from successively farther away water volumes along the beams to determine how much the frequency has changed. The difference in frequency between transmitted and reflected sound is proportional to the relative velocity between the ADCP and the scatters in the water based on the Doppler shift. The profiling range over which an ADCP can resolve water velocities depends upon the frequency of the acoustic signal.

Generally, the lower the frequency the farther the ADCP can measure through the water column however the greater the Doppler uncertainty, all other setting being equal. For example, the typical profiling range of a $1200-\mathrm{kHz}$ ADCP is approximately $15 \mathrm{~m}(50 \mathrm{ft})$, while the range of the $600-\mathrm{kHz}$ model is approximately $47 \mathrm{~m}(150 \mathrm{ft})$. However, the single ping Doppler uncertainty for the $1200-\mathrm{kHz}$ is $3.1 \mathrm{~cm} / \mathrm{s}$ while the $600-\mathrm{kHz}$ is $5.7 \mathrm{~cm} / \mathrm{s}$ ( $1 \mathrm{~m}$ bin size, default settings).

Properties of each beam, including signal correlation magnitude and echo intensity with distance from the transducers, are output from the device. Signal correlation magnitude data show the magnitude of the echo autocorrelation at the lag used for estimating the Doppler phase change. The Workhorse (Teledyne RD Instruments, Inc. [RDI]) represents this magnitude by a linear scale between 0 and 255, where 255 is a perfect correlation (i.e., a solid target). Echo intensity refers to the returned signal strength which is useful for determining cross-talk if a beam hits a solid object and for range measurement to a solid object (e.g., bottom or structure).

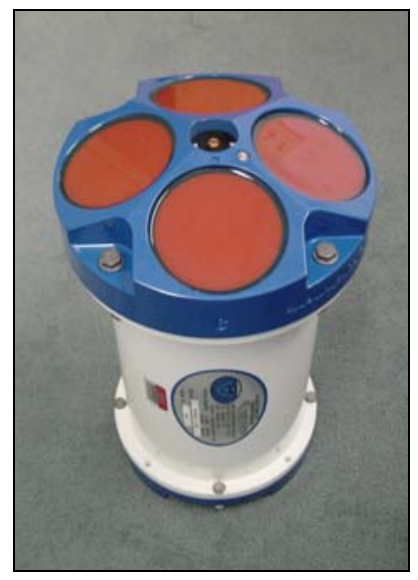

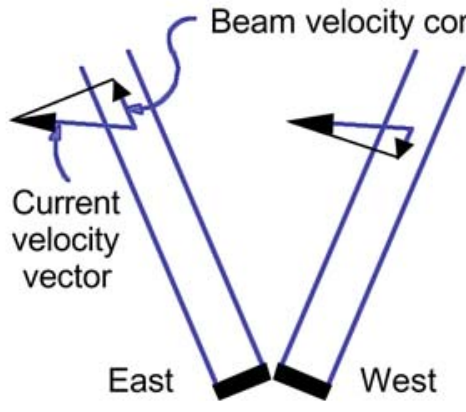

First pair of beams calculates east-west and vertical velocity

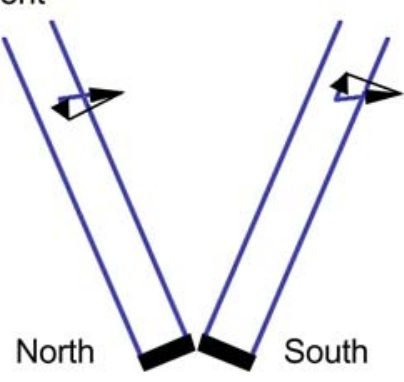

Second pair of beams calculates north-south and vertical velocity

Figure 2.1. $\quad 600-\mathrm{kHz}$ ADCP (left) and Beam Velocity Schematic (right, after RDI 1996). Cardinal directions given in the right-side figure are for descriptive purposes only, and deployment orientation of the ADCP beams was not specific to any coordinate system. 
Each ADCP measurement consists of four 1D water velocity profile measurements along the axis of each acoustic beam (see Figure 2.1). These 1D beam velocities sample only a small volume of water because the acoustic beam emitted by each transducer is intentionally focused and narrow. The halfpower beam-width, defined as the angular measure from the beam centerline to an acoustic energy of $-3 \mathrm{~dB}$ relative to the peak, is less than 1 degree for the RD Instruments ADCPs used in this project. Likewise, the first side lobe peak is at $-35 \mathrm{~dB}$ and 3 degrees while the third side lobe is at $-56 \mathrm{~dB}$ at 7 degrees (P. Devine, RD Instruments, written communication, February 26, 2003).

Under the assumption that water currents are uniform in the plane perpendicular to the transducers' mutual axis, the four 1D beam profile measurements can be combined to compute a profile of 3D water velocities (RDI 1998a). Because only three beams are necessary to compute a 3D water velocity with a Janus-configured ADCP, the fourth beam velocity measurement is used for redundancy and to check for reliability in the homogeneity assumption. It should be noted that even if the homogeneity assumption is violated for resolving a $3 \mathrm{D}$ velocity vector, the $1 \mathrm{D}$ velocity profiles collected along each beam are still valid measurements.

RD Instruments outlines procedures for checking internal electronic components and transducer/receiver health (RDI 1998b). These procedures were performed each morning before the start of data collection to verify ADCP health. Both ADCPs passed all checks.

\subsection{Vessel-Mounted Data Collection}

\subsubsection{Survey Vessels}

To capture synoptic variations of water velocity in the tailrace during the 6-hr spill window, mobile ADCP data were collected using two research vessels. The PNNL R/V Strait Science is a stout 29-ft-long dual-engine motorboat capable of navigating through the sometimes turbulent waters near the operating spillway tailrace. A $600-\mathrm{kHz}$ ADCP was mounted on the gunwale of this boat using a custom-designed mount. The PNNL R/V Sea Star is a smaller 21-ft single-outboard motorboat that was used to measure water velocities in the calmer water downstream of the operating spillway. A 1200-kHz ADCP was mounted on the gunwale of this boat using a custom-designed mount.

Vessels were launched the day before the study and were moored at the USACE forebay marina at the dam overnight. Several hours before spillway operations began, the boats and crew were let through the navigation lock and into the tailrace. Both boats were in radio communication with the John Day Dam control room at all times during the study. In addition, a third motorboat and crew were present in the boat restricted zone (BRZ) for safety any time one of the other boats was collecting data in the BRZ.
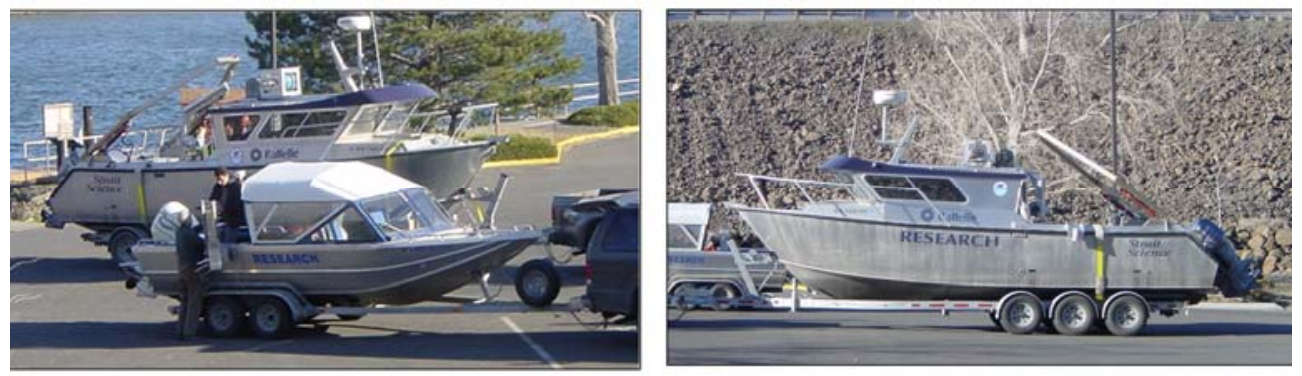

Figure 2.2. $\quad$ Research Vessels Sea Star (left foreground) and Strait Science (right) 


\subsubsection{ADCP Programming}

The $600-\mathrm{kHz}$ ADCP was configured to collect water velocities using one of two scripts. One script was tailored for point measurements when the boat was held approximately in a single position. The ADCP script was configured to collect data using $50-\mathrm{cm}$ bins using the general purpose water mode 1 . Because the velocities were sometimes quite high, the ambiguity velocity was raised (WV300), resulting in single-ping Doppler uncertainties higher than default. To counteract these higher uncertainties, eight water pings were averaged to produce an ensemble reading. In addition, because the boat was in locations with sometimes large waves, eight bottom pings (one per water ping) were also collected. Using RD Instruments specifications, the uncertainty in ensemble measured water velocities is $6.16 \mathrm{~cm} / \mathrm{s}$. The sampling rate to collect the ensemble was $3.2 \mathrm{~s}$, and the distance from the water surface to the first bin centroid was $1.6 \mathrm{~m}(5.2 \mathrm{ft})$.

The second $600-\mathrm{kHz}$ ADCP script was tailored for transect measurements when the boat was moving under power. The ADCP was configured to collect data using 1.0-m bins in mode 1. As before, because the velocities were high, the ambiguity velocity was raised $(300 \mathrm{~cm} / \mathrm{s})$. Because the boat was moving, however, only two water and bottom pings were averaged to form an ensemble reading. Using RD Instruments specifications, the uncertainty in ensemble-measured water velocities can be estimated to be $5.46 \mathrm{~cm} / \mathrm{s}$. Note, because the bin size was higher, fewer pings were needed to attain a comparable ensemble velocity uncertainty as compared to the point-sampling script. The sampling rate to collect the ensemble was $1.0 \mathrm{~s}$, and the distance from the water surface to the first bin centroid was $2.1 \mathrm{~m}(6.9 \mathrm{ft})$.

The 1200-kHz ADCP also was configured to collect data using either a point or discharge measurement script. For point measurements, the ADCP was configured to collect data in $50-\mathrm{cm}$ bins, using mode 1, and with a higher ambiguity velocity as with the $600 \mathrm{kHz}$. The RDI-predicted uncertainty was $2.73 \mathrm{~cm} / \mathrm{s}$ for each ensemble of eight water and bottom pings. The sampling rate to collect an ensemble reading was $4.2 \mathrm{~s}$, and the distance from the water surface to the first bin centroid was $0.8 \mathrm{~m}$ $(2.6 \mathrm{ft})$. For transect or discharge measurements, the ADCP was configured to collect data in $50-\mathrm{cm}$ bins, using model 1, and with a higher ambiguity velocity. The predicted uncertainty was $5.45 \mathrm{~cm} / \mathrm{s}$ for each ensemble of two water and bottom pings. The sampling rate to collect an ensemble reading was $1.1 \mathrm{~s}$, and the distance from the water surface to the first bin centroid was $0.8 \mathrm{~m}(2.6 \mathrm{ft})$.

\subsubsection{Gyrocompass and Differential Global Positioning System}

ADCP data were saved in real time to a computer using RDI WinRiver software. This software was also used to concurrently collect external sensor data with the real-time ADCP data stream. Both vessels were equipped with a TSS Meridian Surveyor gyrocompass and a real-time differential global positioning system (DGPS).

The Meridian Surveyor gyrocompasses were validated before deployment to be within 1 degree of true north. Gyrocompasses were necessary because electric and magnetic fields (EMF) emanating from the hydroelectric dam would have disrupted the ADCP internal flux gate compass. Gyrocompass measurements, which derive heading from the inertial properties of its spinning gyroscope, do not depend upon the earth's magnetic field and are therefore immune to EMF variations.

DGPS data were collected using either a Trimble GeoExplorer with Beacon-on-Belt system or a Trimble TSC1 with Pro-XR Beacon. The DGPS antenna was positioned within $1.5 \mathrm{~m}$ of the ADCP head. 
Because the diverging beams of the ADCP result in a monitored swath that is several meters wide (approximately equal to the water depth for a standard 20-degree unit), no attempt was made to adjust the relatively small offset between DGPS antenna and ADCP head. Outside of real time ADCP data collection, the boat's position was monitored in real time using Trimble Hydropro software, which facilitated navigation to predetermined sampling locations.

\subsubsection{Mobile Velocity Data Processing}

Point and transect velocity measurements were processed using MATLAB and companion toolboxes. This software provides a computing environment in which scripts (similar to $\mathrm{C}++$ code) can be written, debugged, and executed. PNNL-developed scripts read the WinRiver-generated ASCII output files, which contained time-series of acoustic signal metrics, 3D water velocity, GPS, and gyrocompass information.

\subsubsection{Transect Data}

As discussed in Section 2.1, the fourth beam of a Janus-configured ADCP provides redundant velocity component information. By using this information, data can be screened out that do not pass the homogeneity assumption inherent in transforming beam-component velocity magnitudes into a composite $3 \mathrm{D}$ velocity vector. RD Instruments computes a pseudo-RMS error measure using all four beams that is proportional to the horizontal velocity magnitude, which is called an "error velocity" in the RDI literature (RDI 1998a). Velocity data were removed from the database if any reading resulted in an error velocity greater than $15 \mathrm{~cm} / \mathrm{s}(0.5 \mathrm{ft} / \mathrm{s})$. Data were also culled if one of the four beams was bad (i.e., an error velocity could not be computed) or if the bottom track data were bad. After inspection of the data set, it was noted that vertical differences were relatively minor. It was therefore decided to depth-average the moving transect data to reduce the overall size of the data set. Depth averages were computed by first vertically averaging the east, north, and vertical components and then computing the resulting depthaveraged $3 \mathrm{D}$ velocity vector.

\subsubsection{Point Data}

Point data were collected by first maneuvering the boat to one of the predefined monitoring locations. Once there, the captain attempted to hold the boat at that location for at least 10 minutes using an anchor and/or the motor. However, because of swells, it was not possible at many locations to hold the boat steady for the entire sampling period. If the boat drifted away from the intended sampling location, the captain would gently steer the boat back into position. Data collection with the ADCP was not terminated during the location correction; instead, ADCP data were collected continuously and then post-processed after the collection to remove data collected away from the intended location.

The exact culling threshold to remove data collected away from the intended location was challenging to determine. After the collected data were reviewed, it was noted that in some locations water velocities changed dramatically with a small translation of the ADCP. Two such locations were near the navigation lock guide wall and the jet emanating from each operating draft tube. To ensure that movement of the ADCP during data collection was not biasing the sample, a relatively small culling threshold was set, based upon a physical property of the ADCP. Referring back to Figure 2.1, when the ADCP is vertical in the water column, the two orthogonal beams pairs diverge at 20 degrees from the vertical. If the side lobes of the beams are approximately 3 degrees per beam, the maximum distance (i.e., at the bottom of 
the profile) between the paired readings is $2 h \tan \left(23^{\circ}\right)=0.85 h$, where $h$ is the water depth. In other words, the native sampling swath of the ADCP is approximately the water column depth. It is therefore unrealistic to constrain a point ADCP sample to an extremely small horizontal zone because the ADCP is intrinsically sampling over a range slightly less than the water depth. The horizontal sampling cull was therefore set dynamically for each measurement location to be a circle of radius $0.5 h$.

The circle center (and the reported location for the point measurement) was found by calculating the Euclidian distance from each measurement to all other measurements during the sampling period. The measurement with the maximum number of measurements falling within the culling circle was taken as the circle center point (see Figure 2.3). Points falling outside the circle were removed from the data set.

As with the transect data, velocity data were removed from the database if the error velocity of any measurement was greater than $15 \mathrm{~cm} / \mathrm{s}(0.5 \mathrm{ft} / \mathrm{s})$. Data were culled also if one of the four beams was bad (i.e., an error velocity could not be computed) or if the bottom track data were bad.

The set of measurements passing the horizontal location, error velocity, and bottom tracking culls were then averaged over time. Time averages were computed by first temporally averaging the east, north, and vertical components and then computing the resulting time-averaged profile of $3 \mathrm{D}$ velocity vectors.

\subsubsection{Discharge Measurements}

The ability of an ADCP to accurately compute river discharge by integrating velocity measurements from one bank to the other is well documented in the technical literature (see Gordon [1989], Morlock [1996], and Muste et al. [2004a and b] for examples). Simpson (2001) also outlines several useful boat maneuvering and data collection techniques that were followed during the project.

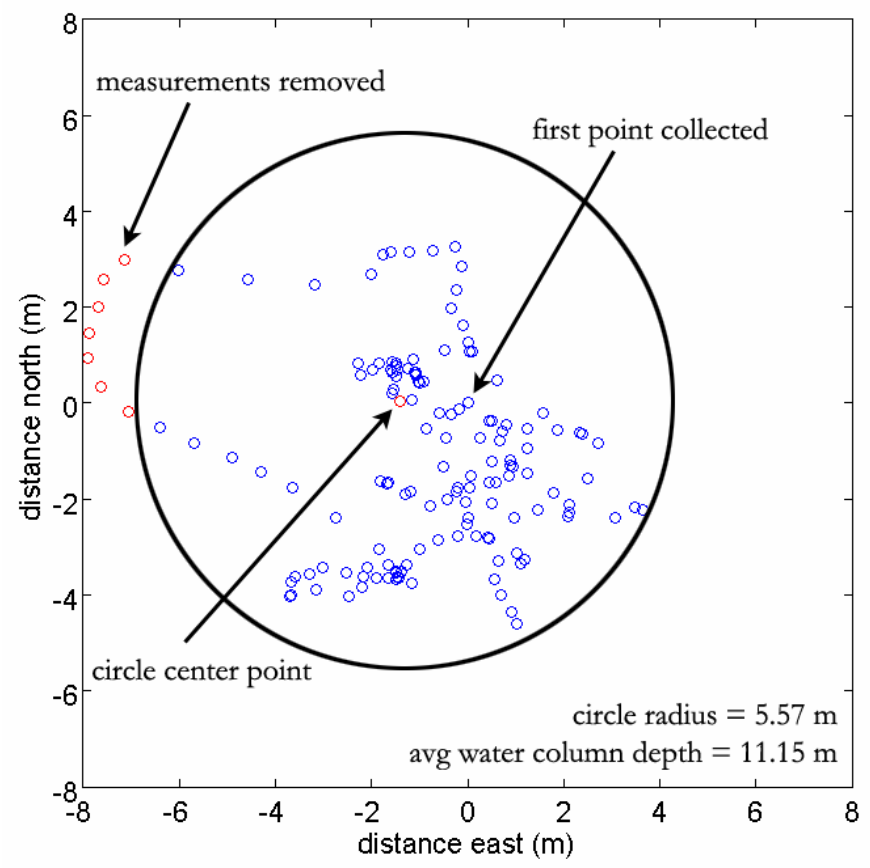

Figure 2.3. Sample Cloud of Mobile Point Measurements (1200 kHz ADCP, February 17, 2005 at $13: 33$ hours) 
Distance from shoreline to the ADCP at both the start and end of each discharge transect was measured using an Impulse 200 laser range finder. Data were collected using the same ADCP configuration script as the moving transecting data measurements discussed above. Default parameters were used for the estimation of top (power), bottom (power), and shoreline edge (triangular) discharges.

\subsection{Powerhouse-Mounted Data Collection}

\subsubsection{ADCP Deployment: Dual-Axis Rotators}

Three ADCPs were mounted just above the Unit 16 draft tube exit so that the acoustic beams could peer into the draft tube while the ADCPs themselves would be out of the direct path of the emerging jet. Unit 16 was selected because it is the operational turbine unit closest to the skeleton bays and spillway. The zone immediately downstream of the Unit 16 draft tube was known from previous studies (and confirmed by this project's mobile survey) to be hydraulically complex.

The ADCPs were articulated using dual-axis rotators (see Figure 2.4) that were controlled from the surface. Two models of rotators were used during the project: 1) RJ Electronics PTE-200 and 2) Remote Oceans Systems (ROS)-PT-25. The PTE-200 is a heavy-duty rotator that is stated to handle $25 \mathrm{ft}-1 \mathrm{~b}$ of torque on each axis. The ROS PT-25 is also a heavy-duty rotator that is designed to handle $30 \mathrm{ft}-\mathrm{lb}$ of torque on each axis. For comparison, the ADCPs were mounted directly to the rotators, and their centers of gravity were not more than $1 \mathrm{ft}$ away from the rotator. The ADCP weights in water were approximately $6.6 \mathrm{lb}$ (composite plastic, no battery) for the $300-\mathrm{kHz}$ unit and $9.0 \mathrm{lb}$ (aluminum housing, no battery) for the $600-\mathrm{kHz}$ units.

Each ADCP, attached to a rotator and mounting bracket (see Figure 2.4), was installed in location by USACE-approved divers through a subcontract with Advanced American Diving Service, Inc. on

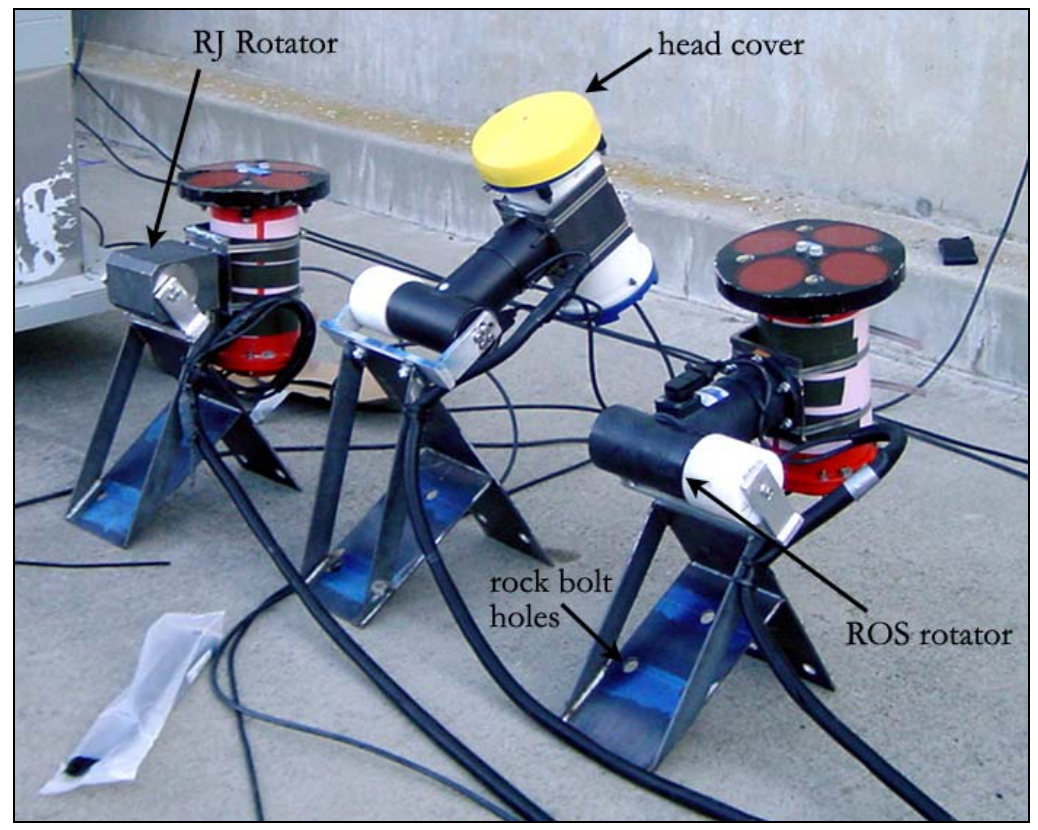

Figure 2.4. ADCPs, Rotators, and Powerhouse Mounts. Left-to-right ADCP order in photo is identical to the order in which the units were deployed. Yellow head cover on the $300-\mathrm{kHz}$ (center) ADCP was removed before deployment. 
February 15, 2005. Each mounting bracket was secured in location by (at least) five rock bolts hammered into the concrete. Deployment locations are shown in context with Turbine Unit 16 in Figures 2.5 and 2.6.

Once deployed, the ADCPs were articulated through a wide range of positions. Figures 2.7 through 2.11 show several of the combinations. The three ADCPs were deployed on February 15 and worked properly until the turbine unit was turned on. The RJ rotator holding the 6-degree ADCP closest to Unit 17 immediately failed to hold the ADCP in position, once discharge started to pass through Unit 16. Although some data were collected, none of it was useful because the instrument pitch and roll could not be held constant. Communication to this instrument was lost on February 18. The ROS rotator holding the other 6-degree ADCP (closest to Unit 15) worked on February 17 and 18. However, during periods of turbine discharge change, it was noted that its position changed suddenly. By February 22, communication with this unit was lost. Divers successfully retrieved the center and south ADCPs. However, the north ADCP and rotator were lost. The bracket holding the rotator to the dam was in place when divers were sent to retrieve the ADCP, so it is hypothesized that the rotator came apart and the ADCP fell to the tailrace bottom.

\subsubsection{Powerhouse-Mounted ADCP Configuration}

Two of the ADCPs were identical custom-made RDI 6-degree beam-spread 600-kHz Workhorse Sentinels. The third unit was a standard 20-degree beam-spread 300-kHz Workhorse Sentinel, with one of the beam pairs (beams 1 and 2) turned off. The beam pair was turned off during the sampling to minimize scattered acoustic energy that could be sent into the other three beams if one of the beams were to hit a solid object. Previous experience collecting ADCP data inside a turbine intake showed that once a single acoustic beam hits a solid concrete surface (an almost perfect reflector), the reflection would be so loud as to corrupt the returning acoustic echoes from the other beam. Note that an ADCP beam cannot be disabled/re-enabled remotely via direct commands. Instead, disabling a beam requires physically unplugging the transducer leads from the receiver board inside of the unit.

The ADCP scripts were configured to collect data at a uniform frequency of $1 \mathrm{~Hz}$. Each profile consisted of a single ping, collected in mode 1 , and divided into either 0.5 - or 1.0-m bins. Because the water was moving rapidly, the ambiguity velocity was raised to prevent aliasing (WV300 or WV400); however, this also raises the Doppler (error) uncertainty. Doppler uncertainty in each ensemble was estimated by RDI (H. Thomas, RDI, written communication, September 28, 2003) and is shown in Table 2.1.

Because more than one of the beams of the $300-\mathrm{kHz}$ ADCP were disabled, three-dimensional velocity vectors cannot be computed. However, the $3 \mathrm{D}$ velocity vectors were computed from the two 6-degree ADCPs. Because the vertical angle is very small for the 6-degree ADCPs, the error uncertainty is very large for 3D-computed velocities. The single-ping standard deviation is approximately $65 \mathrm{~cm} / \mathrm{s}$ (see Table 2.1). If the fluid flow field is not changing over time, the statistical uncertainty of an ensemble can be reduced according to the equation $\frac{61.6}{\sqrt{\mathrm{N}}}$, where $\mathrm{N}$ is the number of single ping measurements. 


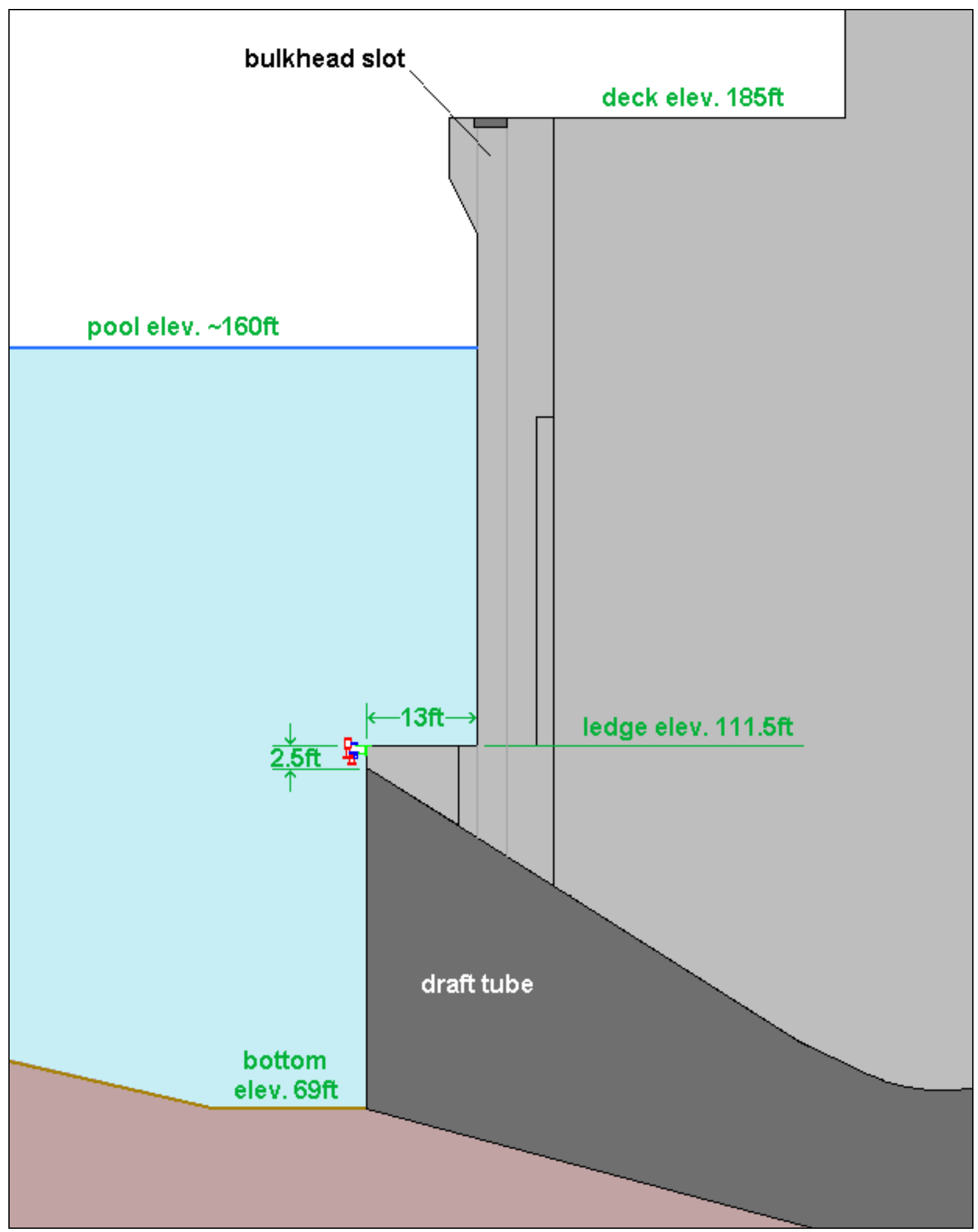

Figure 2.5. Draft Tube and ADCP Deployment (side view). The ADCPs were placed just above the draft tube exit at approximately the same elevation as the ledge $(111.5 \mathrm{ft})$. 


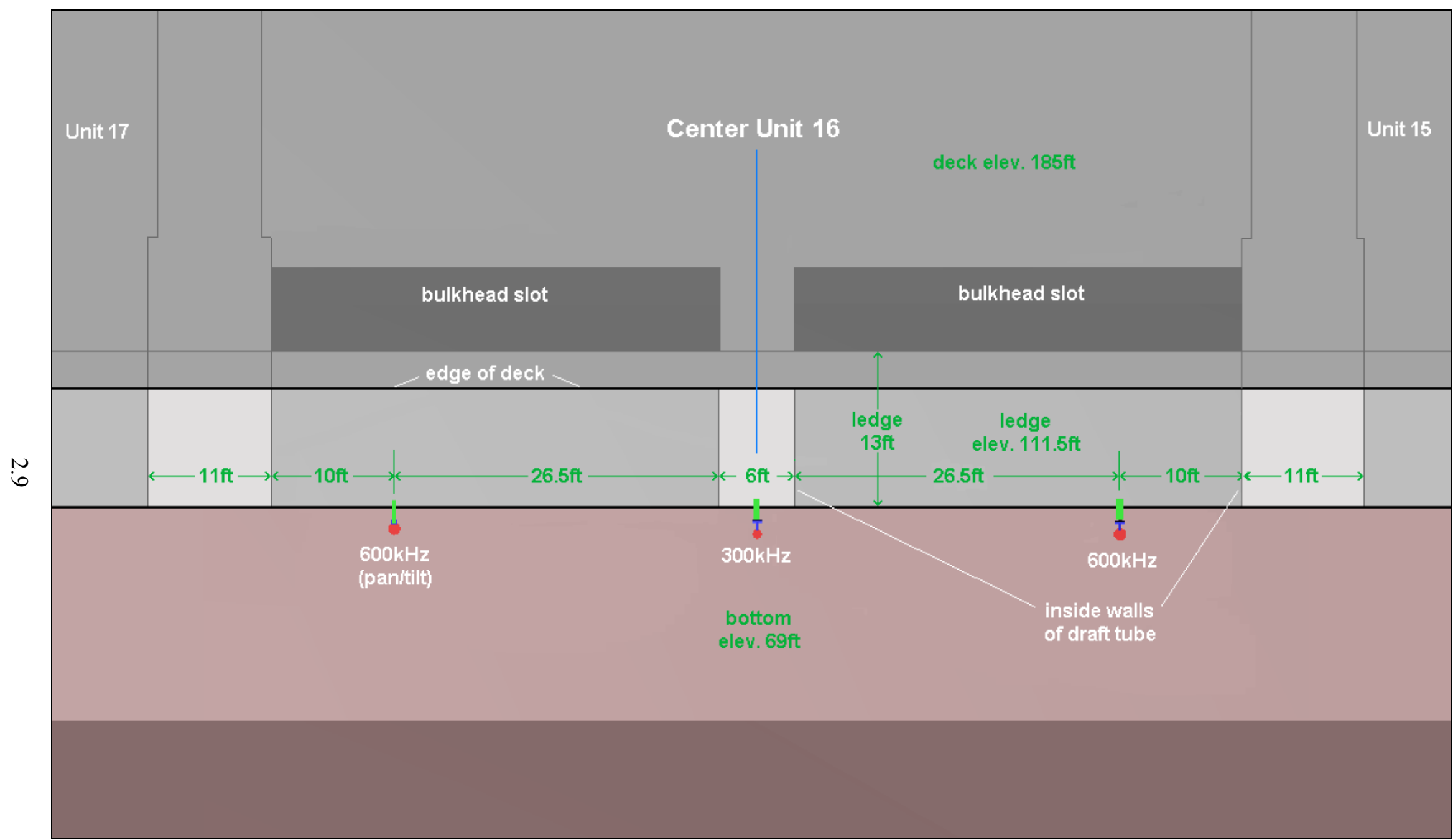

Figure 2.6. Draft Tube and Deployment Schematic (plan view) 


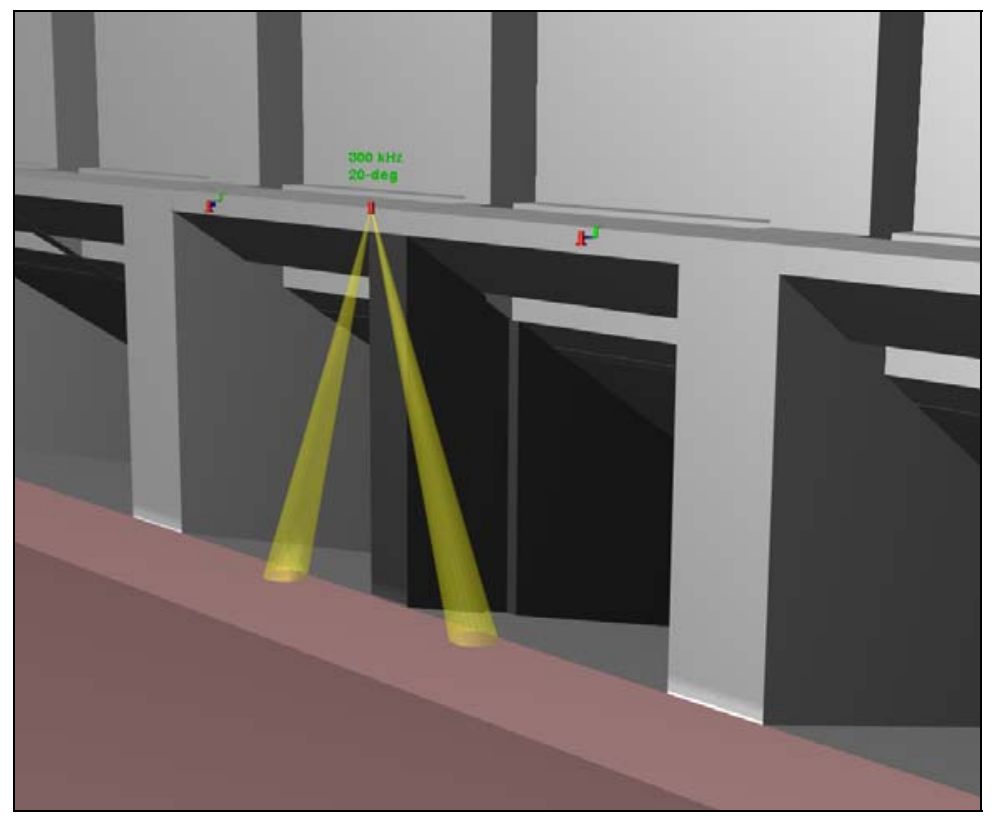

Figure 2.7. Center 300-kHz ADCP Oriented to Look Straight Down. Yellow individual beams were drawn (conservatively) at 3 degrees from the centerline axis to cover the first side lobe peak and to improve visualization (see Section 2.1. RDI $-3 \mathrm{~dB}$ reported beam width is less than 1 degree).

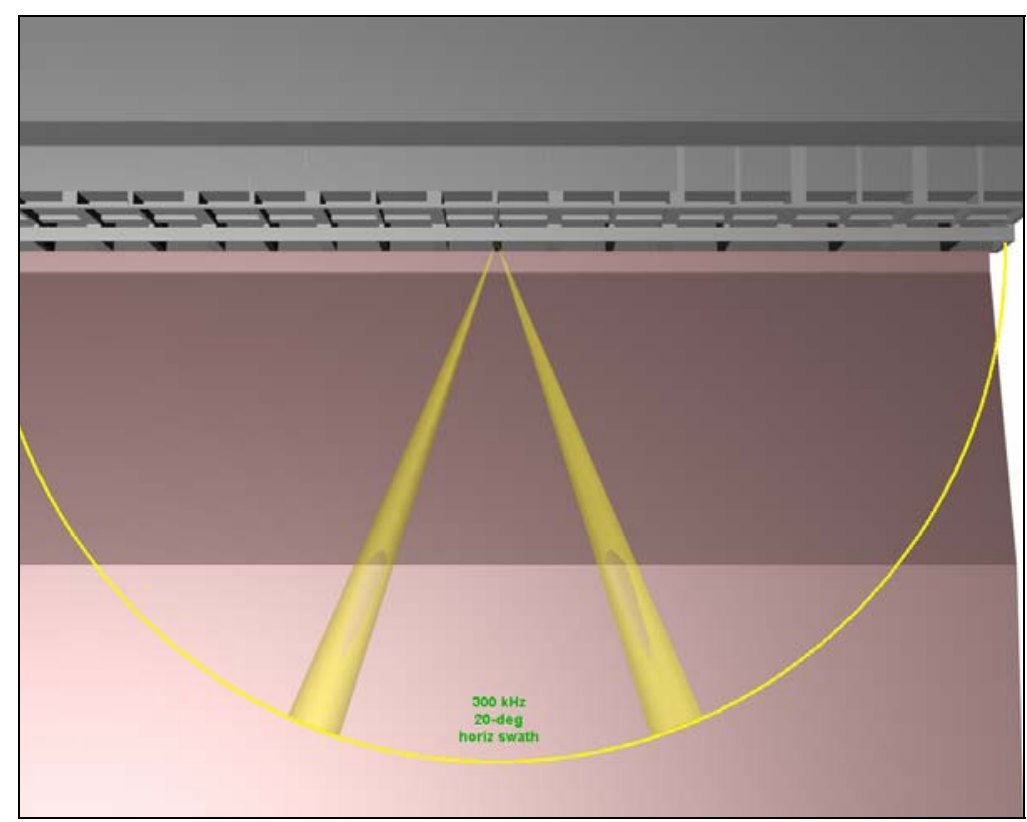

Figure 2.8. Side-to-Side Coverage Swath of the Center 300-kHz ADCP Beams. Swath extends from approximately Unit 12 to Unit 20. Yellow individual beams were drawn (conservatively) at 3 degrees. 


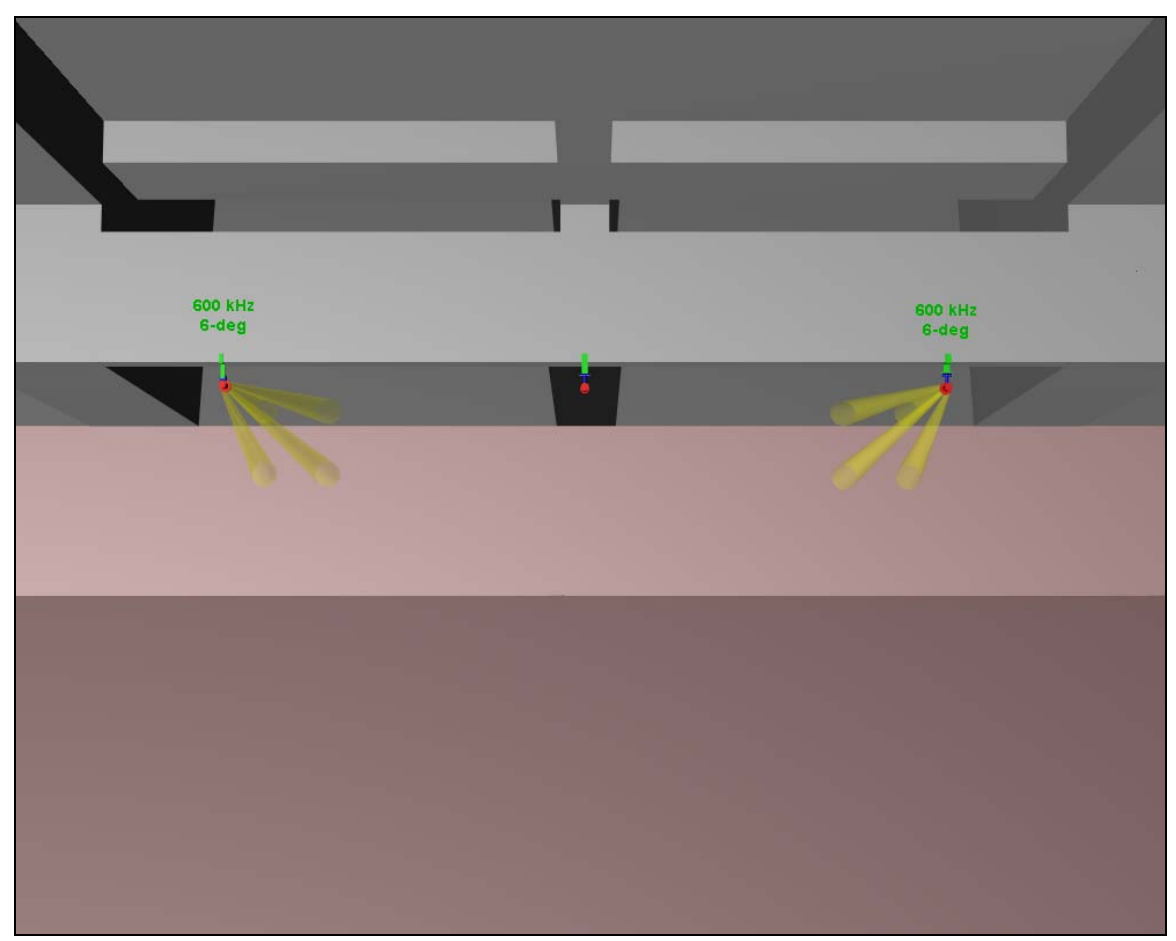

Figure 2.9 Left and Right 600-kHz ADCPs Looking Straight Down. Yellow individual beams were drawn (conservatively) at 3 degrees.

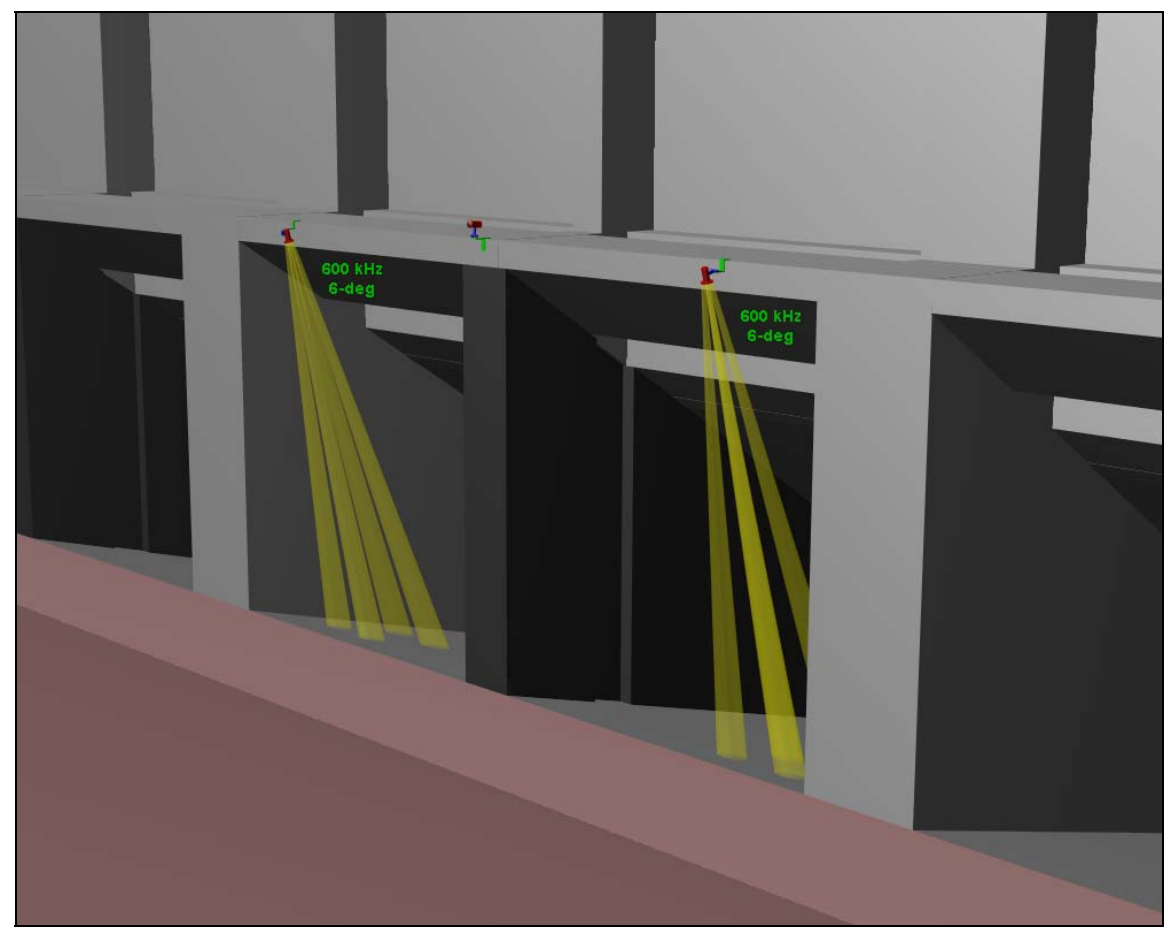

Figure 2.10. Left and Right 600-kHz ADCPs Oriented to Look into the Draft Tubes. Yellow individual beams were drawn (conservatively) at 3 degrees. 


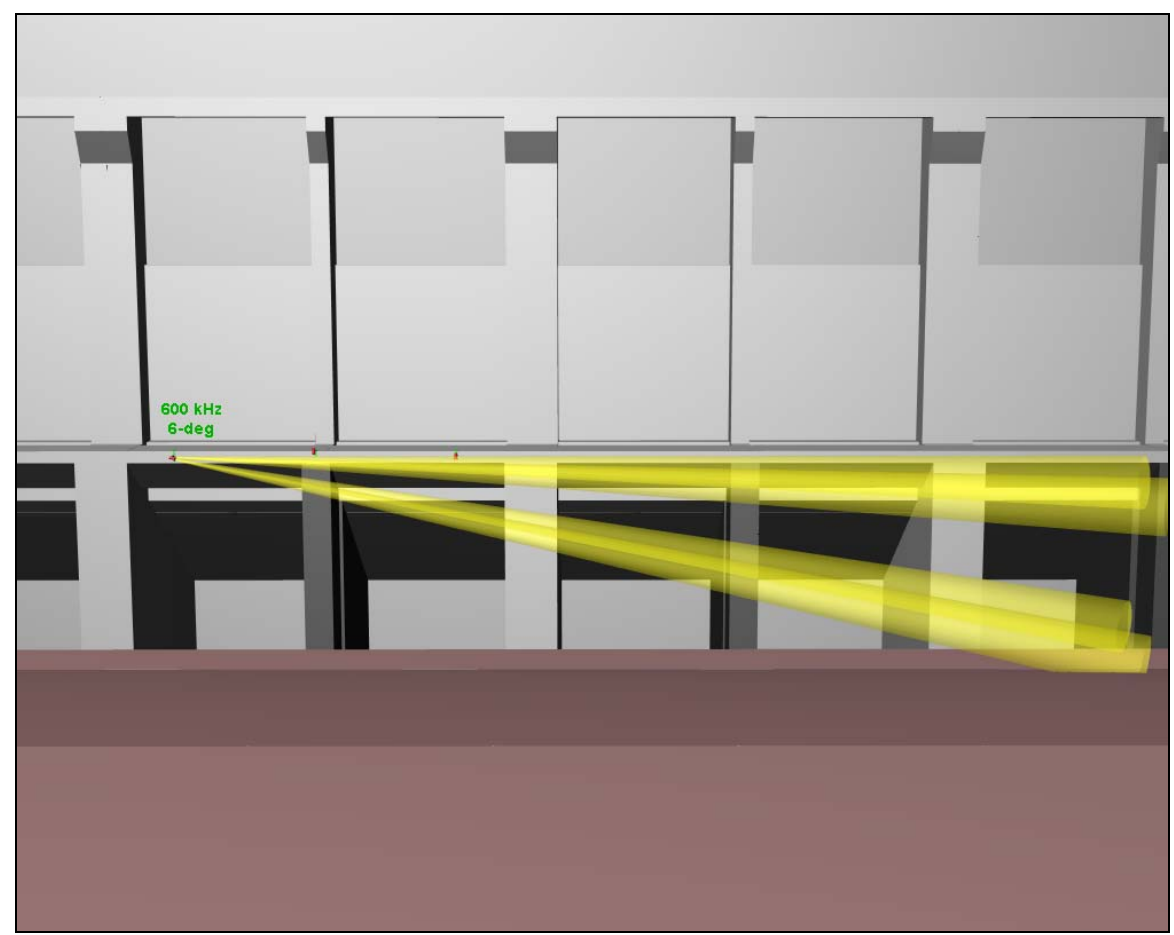

Figure 2.11. 600-kHz ADCP Oriented to Look Sideways. Beam swaths extend across Unit 16, Unit 15, and part of Unit 14. Yellow individual beams were drawn (conservatively) at 3 degrees.

Table 2.1. Along-Beam (radial) Velocity Uncertainties for Powerhouse-Mounted ADCPs. Source: RDI (2005)

All values are for Mode 1.

\begin{tabular}{|c|c|c|c|c|c|}
\hline frequency $(\mathrm{kHz})$ & beam angle & bin size $(\mathrm{m})$ & $\begin{array}{c}\text { ambiguity } \\
\text { velocity }(\mathrm{cm} / \mathrm{s})\end{array}$ & $\begin{array}{c}\text { along-beam (1D) } \\
\text { uncertainty }(\mathrm{cm} / \mathrm{s})\end{array}$ & $\begin{array}{c}\text { single-ping } \\
\text { 3D uncertainty }(\mathrm{cm} / \mathrm{s})\end{array}$ \\
\hline 300 & 20 & 50 & 300 & 13.6 & $\mathrm{n} / \mathrm{a}$ \\
300 & 20 & 50 & 400 & 13.7 & $\mathrm{n} / \mathrm{a}$ \\
300 & 20 & 100 & 300 & 6.8 & $\mathrm{n} / \mathrm{a}$ \\
300 & 20 & 100 & 400 & 6.9 & $\mathrm{n} / \mathrm{a}$ \\
\hline 600 & 6 & 50 & 300 & 9.7 & 65.5 \\
600 & 6 & 50 & 400 & 9.7 & 65.7 \\
\hline
\end{tabular}

Sampling at $1 \mathrm{~Hz}$, the ensemble uncertainty would drop to just under $8 \mathrm{~cm} / \mathrm{s}$ for a 1 -minute average, which was the minimum sample collection period used during the project. Most collection periods were longer than 5 minutes.

\subsubsection{Along-Beam Velocity Data: Sample Volume and Comparison to Physical Model Data}

The along-beam, or 1D, velocity measurement is the most accurate measure of velocity produced by the ADCP. The error uncertainty produced by these along-beam measurements is less than one-seventh the uncertainty of 3D earth transformed velocities for the 6-degree ADCP (see Table 2.1). The alongbeam volume over which the ADCP samples is relatively small compared to the distance between orthogonal beam pairs. The half-power $(-3 \mathrm{~dB})$ width of the 6-degree $600-\mathrm{kHz}$ ADCP $(11.5 \mathrm{~cm}$ transducers) is 0.45 degree off the centerline of the beam's axis (RDI 2003). If the main beam is 
simplified to be a cone emanating from the transducer, any slice through the cone will produce a circle, and the distance between two slices (the bin size) will produce a tapered cylinder (i.e., frustum of a right circular cone). As an example, consider a distance $15 \mathrm{~m}$ (49 ft) from the ADCP head (approximate distance from the ADCP to the bottom of the draft tube). At this distance, the half-power width of the beam is approximately $0.35 \mathrm{~m}\left(15^{*} \tan \left(0.45^{\circ}\right) * 2+0.115 \mathrm{~m}\right.$ transducer size $)$, and at $15.5 \mathrm{~m}$ the width is $0.36 \mathrm{~m}(1.2 \mathrm{ft})$. The volume integrated by the ADCP beam used to compute the along-beam velocity is $\mathrm{V}=\frac{\pi \mathrm{h}}{12}\left(\mathrm{D}_{\mathrm{B}}^{2}+\mathrm{D}_{\mathrm{B}} \mathrm{D}_{\mathrm{T}}+\mathrm{D}_{\mathrm{T}}^{2}\right)$, where $\mathrm{D}_{\mathrm{B}}$ is the diameter at the bottom of the tapered cylinder, $\mathrm{D}_{\mathrm{T}}$ is the diameter at the top, and $\mathrm{h}$ is the bin size. For this example (distance of $15 \mathrm{~m}$; $0.5-\mathrm{m}$ bin size), the integrated beam volume is approximately $0.049 \mathrm{~m}^{3}\left(1.74 \mathrm{ft}^{3}\right)$. For comparison, the integrated beam volume at a distance of $2 \mathrm{~m}$ from the ADCP head is only $0.001 \mathrm{~m}^{3}\left(0.31 \mathrm{ft}^{3}\right)$.

Along-beam, or 1D, ADCP measurements are useful to both physical and numerical modelers when model results are projected onto the beam path using the dot (or scalar) product operation. Figure 2.12 first graphically explains an along-beam velocity measurement. In Figure 2.12, $\mathbf{V}=\mathrm{V}_{\mathrm{x}} \mathbf{i}+\mathrm{V}_{\mathrm{y}} \mathbf{j}+\mathrm{V}_{\mathrm{z}} \mathbf{k}$ is the flow velocity vector with corresponding $\mathrm{X}, \mathrm{Y}$, and $\mathrm{Z}$ scalar velocity components. Vector $\mathbf{n}$ is a unit vector and points in the direction of one of the ADCP beams. The dot product result of $\mathbf{V}$ and $\mathbf{n}$ is the scalar $\mathrm{V}_{\text {bin(a) }}$ and represents the magnitude of flow velocity vector $\mathbf{V}$ in the direction of beam vector $\mathbf{n}$ for bin(a) (i.e., the 1D or along-beam velocity measured by the ADCP). Because the continuous ADCP acoustic beam is decomposed into equal length bins of user programmable length (typically 0.5 or $1.0 \mathrm{~m}$ ), the number of measured bins can vary. In Figure 2.12, only four bins are shown; however, the ADCP can typically measure up to a maximum of 128 discrete bins.

The process for comparing model generated velocity vectors to ADCP values is similar to how the ADCP measures the water velocity. A physical or CFD model value corresponding in space to the same location as one of the bin values (i.e., $\mathrm{V}_{\mathrm{bin}(\mathrm{a})}$ ) is first identified. The modeled velocity vector is then projected onto the ADCP beam vector $\mathbf{n}$. The scalar magnitude result can then be compared directly to the measured $\mathrm{ADCP}$ value $\left(\mathrm{V}_{\text {bin(a) }}\right)$.

As a step-by-step example of how to compare physical or numerical model data to ADCP along-beam data, we compared single-beam ADCP measurements collected in the draft-tube exit of Turbine Unit 16 operating at $16 \mathrm{kcfs}$ to laser Doppler velocimeter (LDV) measurements obtained in the 1:25 scale

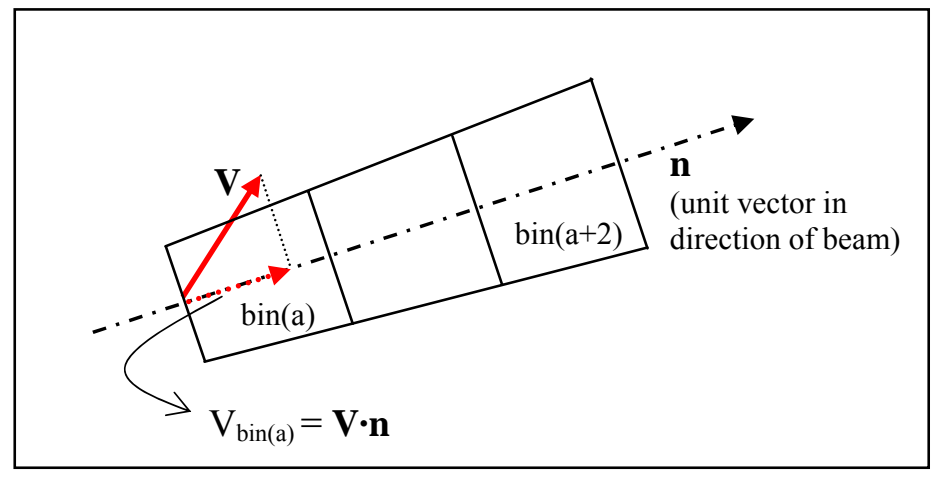

Figure 2.12. Graphical Representation of an ADCP Measured Along-Beam, or 1D, Velocity Magnitude. The 1D scalar magnitude is oriented in the direction of the beam, $n$, and is equal to the dot product operation of $\mathrm{V}$ and $\mathrm{n}$. 
physical model of a Lower Granite Dam turbine unit operating at $17.7 \mathrm{kcfs}$ (Davidson 2004). Although these dams are located on two different rivers, exit geometries of their draft tubes are nearly identical. The purpose of this example, however, is to demonstrate the method for comparing along-beam ADCP data to physical model data, not to evaluate the agreement between the two data sets.

The first step of the comparison begins with identifying places where measurement locations coincide. ADCP results occur at regularly spaced intervals along the beam extending out from the transducers in a straight line. The sample LDV measurements occupy locations in vertical planar cross sections parallel to the draft-tube exit axis. Figure 2.13 shows the relationship between the two data sets. The purple dots indicate the locations of single-beam velocities from two ADCP beams collected at two different times but at similar turbine discharge. The green plane represents cross-section ZG from the physical model data set. The data sets coincide where the beams intersect the plane. In Figure 2.13, red arrows have been placed on the ADCP beam closest to each intersection in the direction of the alongbeam velocity.

The next step is to determine the direction of the ADCP beams relative to the LDV velocity vectors. The ADCP along-beam velocity is directed parallel to the beam, either toward or away from the transducer. The orientation of this scalar measurement is computed from the orientation angles, tilt and elevation, associated with the ADCP rotator. Having this direction information, we can represent the along-beam velocity as a three-dimensional vector by multiplying the measured velocity magnitude (a scalar) by the 3D unit vector parallel to the beam (red arrows in Figure 2.13).

The final step is to project the LDV vectors onto the ADCP vectors so that we can make a direct comparison. This is accomplished by taking the dot product of the physical model velocity vector with the unit vector representing the beam direction (Figure 2.12). The scalar component of the physical model velocity vector can now be compared directly to the along-beam ADCP measurement.

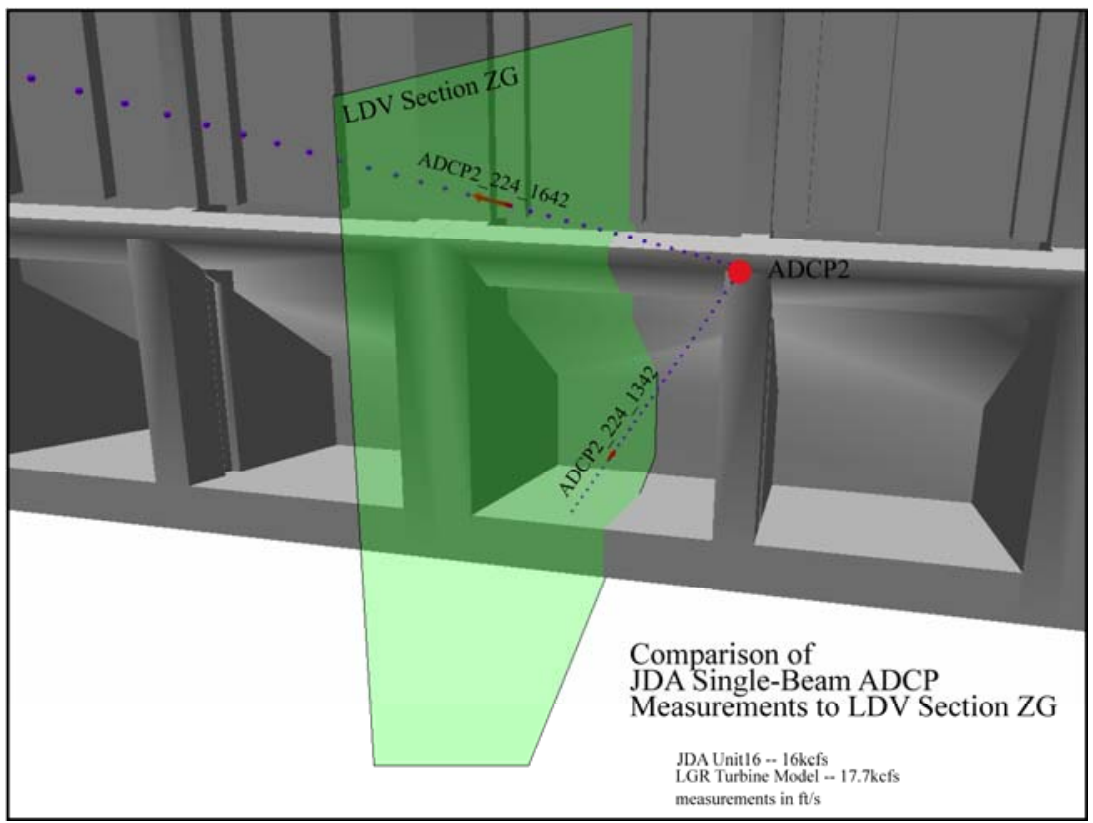

Figure 2.13. Graphical Comparison of Along-Beam ADCP Measurements to a Laser Doppler Velocimeter Plane Measured in Lower Granite Dam Physical Model 


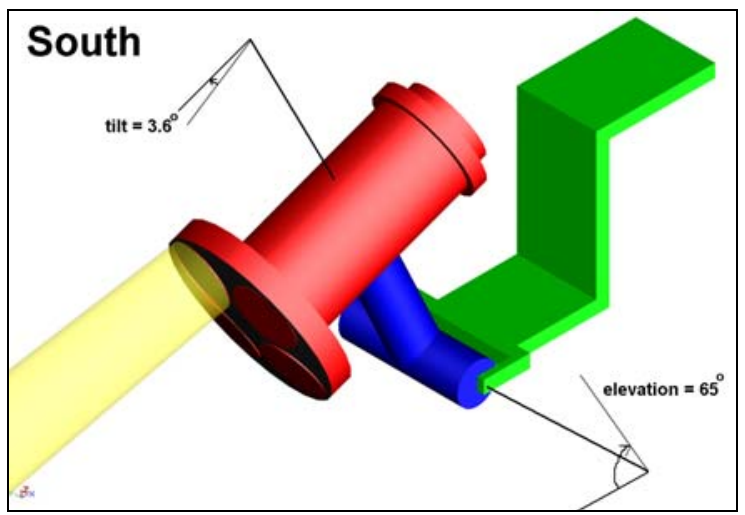

Figure 2.14. ADCP Mounted onto a Dual-Axis Rotator (blue) and Mount (green)

Figure 2.15 illustrates this comparison by showing a side view portraying LDV physical model vectors for cross-section ZG (black arrows) and the ADCP beams (purple dots). The two insets display scaled arrow comparisons at these two locations, with the purple arrow representing the physical model vector in the direction of the ADCP beam in purple and the along-beam ADCP measurement in red. The ADCP beam intersection did not coincide with a reported LDV measurement, the closest value was selected.

The technique just described compares only one directional component of the physical model velocity to the ADCP along-beam measurement. Even if this comparison results in identical values, there is no guarantee that the two measurements represent identical flow conditions at that location. This is due to the inherent limitation of the single-beam data to collect only one component of the velocity field. As Figure 2.16 shows, a specific along-beam velocity component could result from an infinite number of 3D flow velocities. However, if additional comparisons at other locations continue to agree, the likelihood of

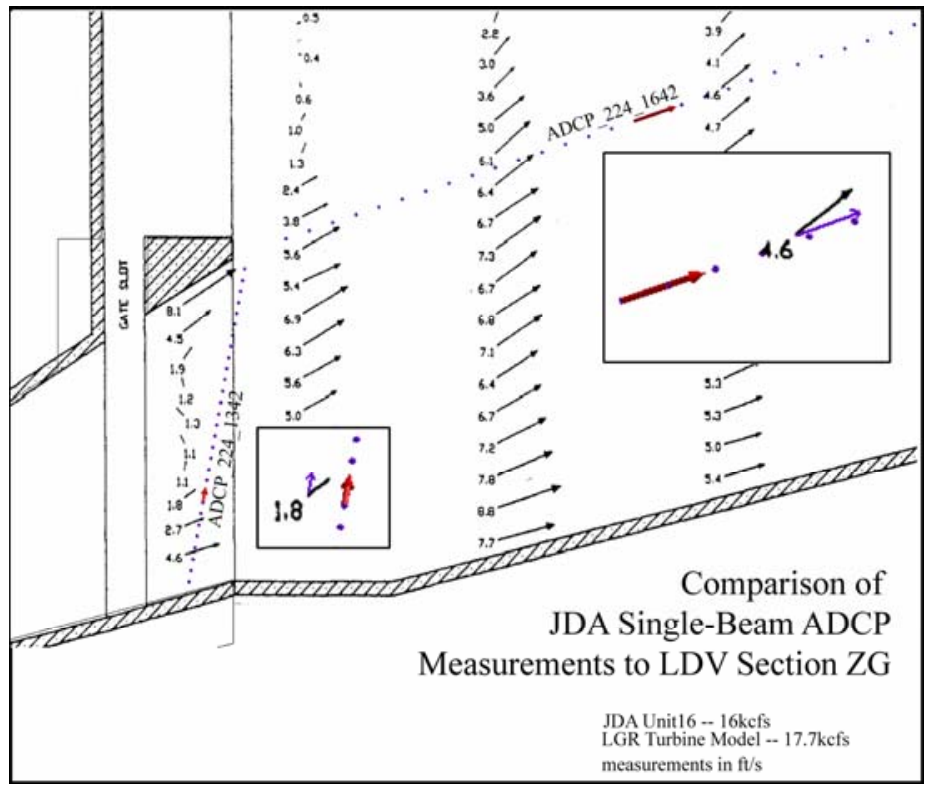

Figure 2.15. Scaled Comparison of Results from an Along-Beam ADCP (red arrows) and Projected LDV Measurement (purple arrows). LDV measurement source: Davidson (2004). 


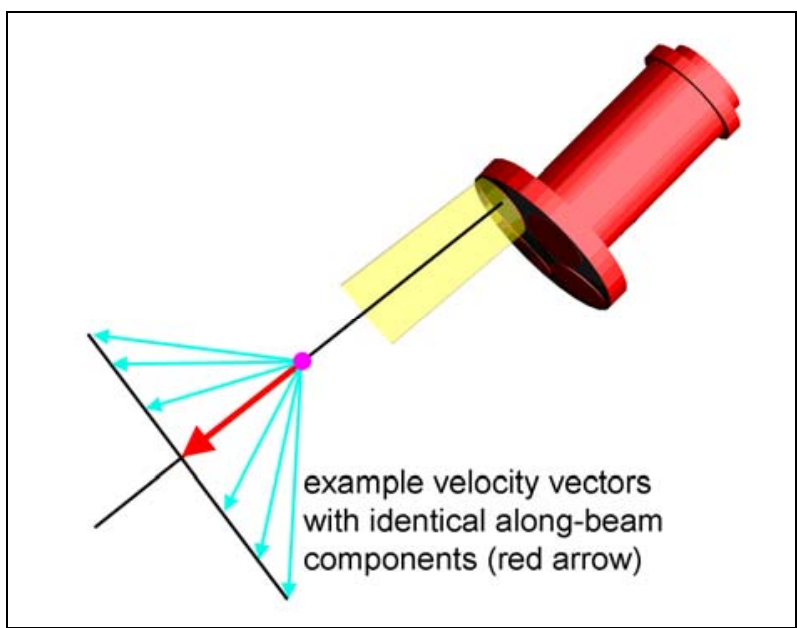

Figure 2.16. Along-Beam Velocity (red) and Some of the Possible 3D Velocity Vectors (light blue lines) That Contain Identical Along-Beam Direction Velocity Components

sampling two different flow fields decreases due to mass conservation, so confidence in model-generated results can be increased using the validation techniques described here.

\subsubsection{Along-Beam Velocity Filters: Root Mean Square Velocity Fluctuations and Homogeneity Index}

Two statistics, or indexes, were developed to help analyze the ADCP data collected at the powerhouse. The first index is a measure of how much temporal velocity variation occurred over the sampling period and was generated for all powerhouse measurements. The second index is a measure of the homogeneity of the flow field between the four beams. This index is relevant only when 3D velocities were computed from data collected using the 6-degree ADCP.

The temporal variation index was computed by first computing the mean velocity in a specific bin over the sampling period. This mean velocity was then subtracted from each individual reading to generate a time series of velocity fluctuations. Fluctuations were then squared, the time-averaged mean value was evaluated, and the square root of this mean was then computed. Mathematically, this index can be written as

$$
\begin{aligned}
& \mathrm{B}_{1}^{\prime}=<\mathrm{B}>-\mathrm{B}_{1} \\
& \mathrm{RMS}=\sqrt{<\left(\mathrm{B}^{\prime}\right)^{2}>}
\end{aligned}
$$

where $\mathrm{B}_{1}$ is the along-beam velocity for one particular beam at time $1,<\mathrm{B}>$ represents the time-averaged mean of $\mathrm{B}, \mathrm{B}^{\prime}{ }_{1}$ is the velocity fluctuation from the mean at time 1 , and RMS is the root-mean-square of the velocity fluctuation. This index is sometimes called a 1D turbulence intensity. However, because of the relatively large bin size $(0.5 \mathrm{~m})$ and the relatively slow sampling rate $(1.33 \mathrm{~Hz})$, this phrase is not used in this report, and the index is instead called an RMS velocity fluctuation.

A sample of along-beam data is shown in Figure 2.17 for data collected by ADCP1 on February 17, 2005, at 14:46 hours. (ADCP1 is the south ADCP, closest to Unit 16; see Figure 2.6.) Data were collected at $20.1 \mathrm{ft}$ from the ADCP, Unit 16 turbine discharge was $15.3 \mathrm{kcfs}$ (varied $0.1 \mathrm{kcfs}$ during sample), and the sample was collected over a period of approximately 10.5 minutes ( 845 samples). The 


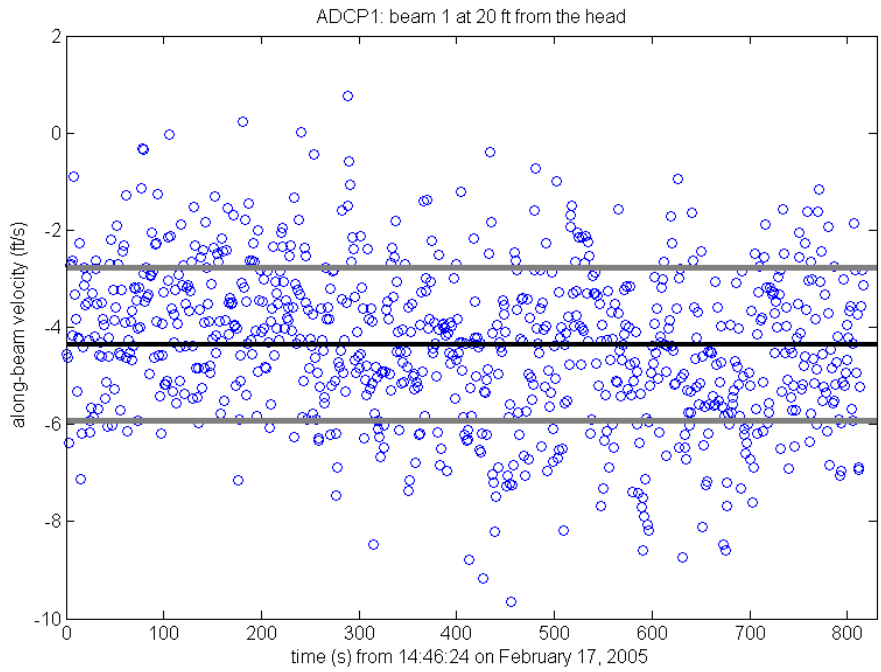

Figure 2.17. Sample Along-Beam Data Collected by ADCP1 (south ADCP, closest to Unit 16). Mean velocity for sample is $-4.3 \mathrm{ft} / \mathrm{s}$ (away from transducer head), and the RMS velocity fluctuations are $\pm 1.6 \mathrm{ft} / \mathrm{s}$ (gray lines above and below the black mean line).

computed RMS fluctuations are $1.6 \mathrm{ft} / \mathrm{s}$, which was typical for measurements taken within proximity to the draft tube exit. Profiles of mean velocities and associated RMS values from all four beams for the sampling period are shown in Figure 2.18. These values are typical of those recorded by the ADCP, and measured RMS velocity fluctuation values generally ranged between 0.5 and $3.0 \mathrm{ft} / \mathrm{s}$ over the sampling period.
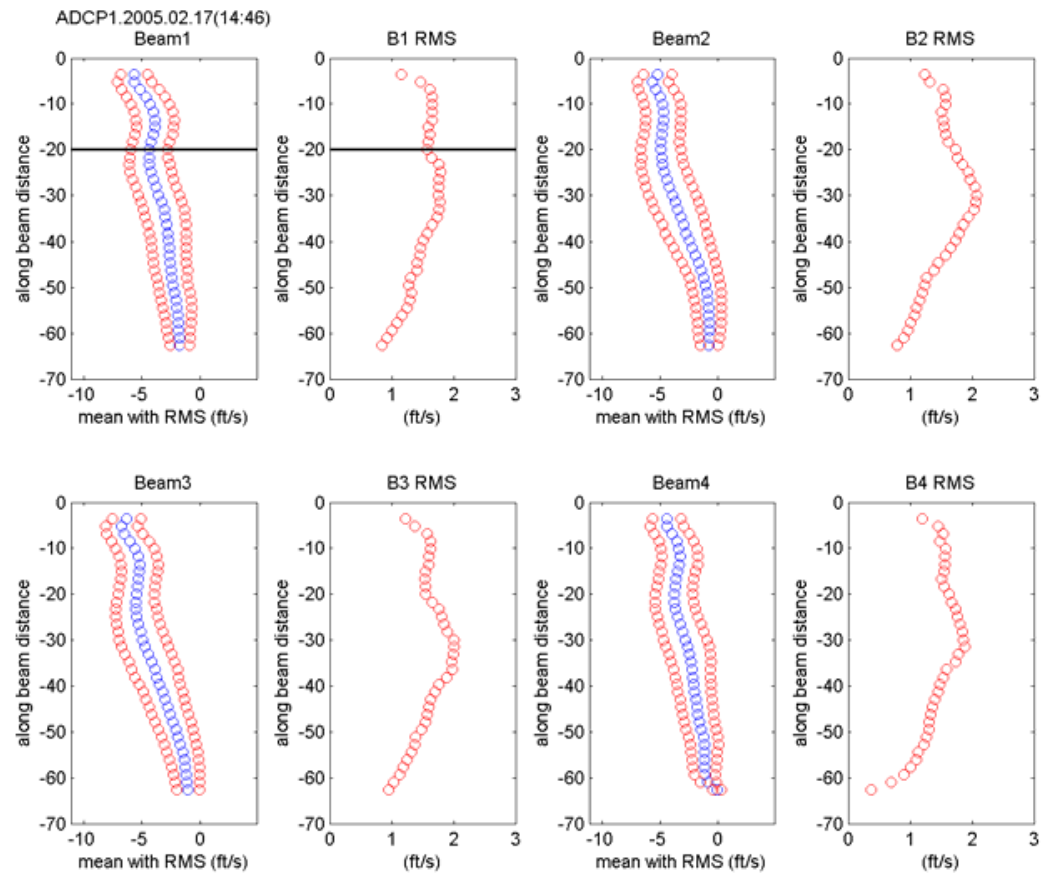

Figure 2.18. Profiles of Mean Velocity (blue circles) and RMS Velocity Fluctuations (red circles)

Collected by ADCP1 on February 17, 2005. The black line drawn across Beam 1 values at $20 \mathrm{ft}$ is for comparison to Figure 2.17. 
The profiles of $\mathrm{ADCP}$ beam data can be used to compute a profile of $3 \mathrm{D}$ velocity vectors if the flow field measured by each beam is relatively similar. For this discussion, a coordinate system has been developed that is oriented with the instrument head pointing downward. The vertical (or W) velocity direction is aligned with the centerline of the ADCP, and the $\mathrm{U}$ and $\mathrm{V}$ velocity directions are the horizontal directions. The equations to compute the $3 \mathrm{D}$ instrument oriented velocity vectors are

$$
\begin{aligned}
& \mathrm{U}=\frac{1}{2 \sin (\theta)}(\mathrm{B} 1-\mathrm{B} 2) \\
& \mathrm{V}=\frac{1}{2 \sin (\theta)}(\mathrm{B} 3-\mathrm{B} 4) \\
& \mathrm{W}=\frac{1}{4 \cos (\theta)}(\mathrm{B} 1+\mathrm{B} 2+\mathrm{B} 3+\mathrm{B} 4)
\end{aligned}
$$

where $\theta$ is ADCP beam angle ( 6 degree). Because only three non-colinear beams are necessary to resolve a $3 \mathrm{D}$ velocity field, data from the fourth $\mathrm{ADCP}$ beam are technically redundant. However, having a redundant beam is useful for computing homogeneity of the flow field, which was exploited here. Because $\cos \left(6^{\circ}\right)$ is 0.994 , the majority of the ADCP beam value is in the vertical direction (instrument coordinate system). A homogeneity index was computed by first calculating the various combinations of three beam vertical velocities:

$$
\begin{array}{ll}
\mathrm{W}_{\mathrm{a}}=\frac{1}{3 \cos (\theta)}(\mathrm{B} 1+\mathrm{B} 2+\mathrm{B} 3) & \mathrm{W}_{\mathrm{b}}=\frac{1}{3 \cos (\theta)}(\mathrm{B} 1+\mathrm{B} 2+\mathrm{B} 4) \\
\mathrm{W}_{\mathrm{c}}=\frac{1}{3 \cos (\theta)}(\mathrm{B} 1+\mathrm{B} 3+\mathrm{B} 4) & \mathrm{W}_{\mathrm{d}}=\frac{1}{3 \cos (\theta)}(\mathrm{B} 2+\mathrm{B} 3+\mathrm{B} 4)
\end{array}
$$

To compute these values, the time-averaged along-beam values were used because the RMS velocity fluctuations already provided an index for looking at temporal variations. These four values were then subtracted from each other and squared:

$$
\begin{array}{lll}
\mathrm{D}_{1}=\left(\mathrm{W}_{\mathrm{a}}-\mathrm{W}_{\mathrm{b}}\right)^{2} & \mathrm{D}_{2}=\left(\mathrm{W}_{\mathrm{a}}-\mathrm{W}_{\mathrm{c}}\right)^{2} & \mathrm{D}_{3}=\left(\mathrm{W}_{\mathrm{a}}-\mathrm{W}_{\mathrm{d}}\right)^{2} \\
\mathrm{D}_{4}=\left(\mathrm{W}_{\mathrm{b}}-\mathrm{W}_{\mathrm{c}}\right)^{2} & \mathrm{D}_{5}=\left(\mathrm{W}_{\mathrm{b}}-\mathrm{W}_{\mathrm{d}}\right)^{2} & \mathrm{D}_{6}=\left(\mathrm{W}_{\mathrm{c}}-\mathrm{W}_{\mathrm{d}}\right)^{2}
\end{array}
$$

Finally, the homogeneity index was computed by computing the square-root-mean of the D values:

$$
\text { Homogeneity Index }=\sqrt{\frac{\mathrm{D}_{1}+\mathrm{D}_{2}+\mathrm{D}_{3}+\mathrm{D}_{4}+\mathrm{D}_{5}+\mathrm{D}_{6}}{6}}
$$

This homogeneity value was then computed for all powerhouse ADCP data. It was found to be highly effective at removing erroneous values from the data set and provides a sliding index that could be adjusted depending upon need (data purity versus some meaningful, although noisy, data).

A sample profile of the homogeneity index values for ADCP1 (the south ADCP closest to Unit 16) on February 17, 2005, at 14:46 hours, is show in Figure 2.19. Index values all were less than $0.5 \mathrm{ft} / \mathrm{s}$ along the profile and a relatively small percentage of the median along-beam value. After all data collected by the powerhouse ADCPs were examined, a homogeneity index value of $0.7 \mathrm{ft} / \mathrm{s}$ was used to screen out data shown in Appendix B. This value was chosen arbitrarily and could be adjusted later depending upon how 
the $3 \mathrm{D}$ velocity was used. If highly precise values are required for model calibration, a smaller value of the homogeneity index may be used to filter the data set. All data regardless of homogeneity index have been preserved and reported, along with corresponding homogeneity index values.

The resulting 3D velocities shown in the right side of Figure 2.19 were then translated and rotated in a real-space coordinate system. Resulting velocity vectors were then plotted, along with line work detailing the powerhouse structure. A sample result is shown in Figure 2.20. The left side of Figure 2.20 is a side view, and water is exiting the draft tube from the left. The ADCP is generally oriented downward and is looking into the tailrace. The right side of Figure 2.20 is a plan view, which allows one to see that ADCP1 was also rotated slightly toward Unit 15 . The velocity vectors have been colored by velocity magnitude. Similar figures for all 3D velocity vectors can be viewed in Appendix B.

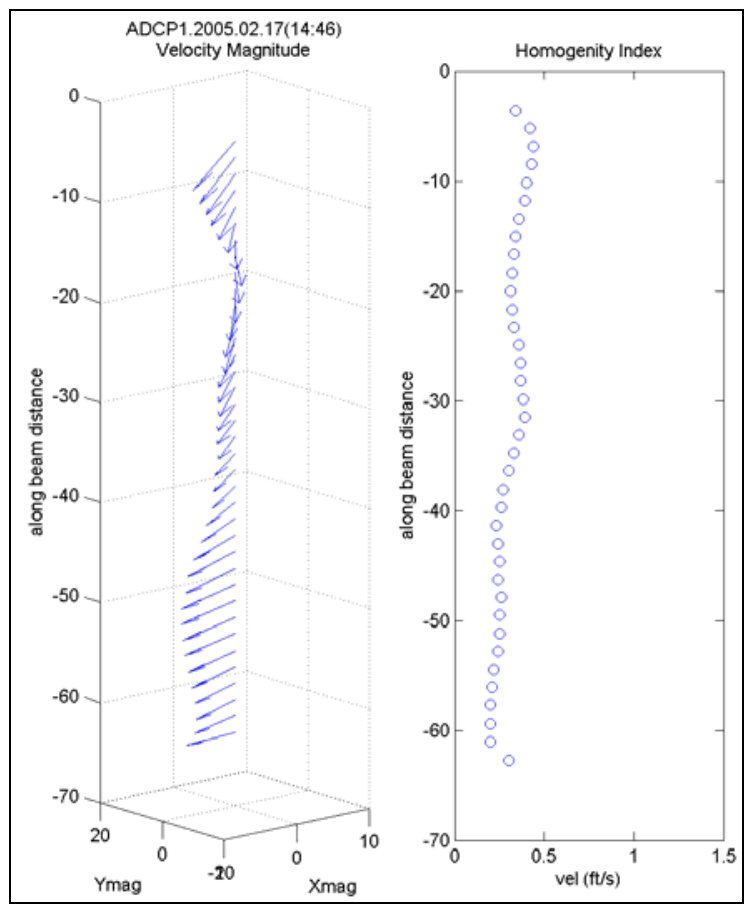

Figure 2.19. Profiles of 3D Water Velocity (left) and Homogeneity Index (right) for Data Collected by ADCP1 on February 17, 2005, at 14:46 hours 


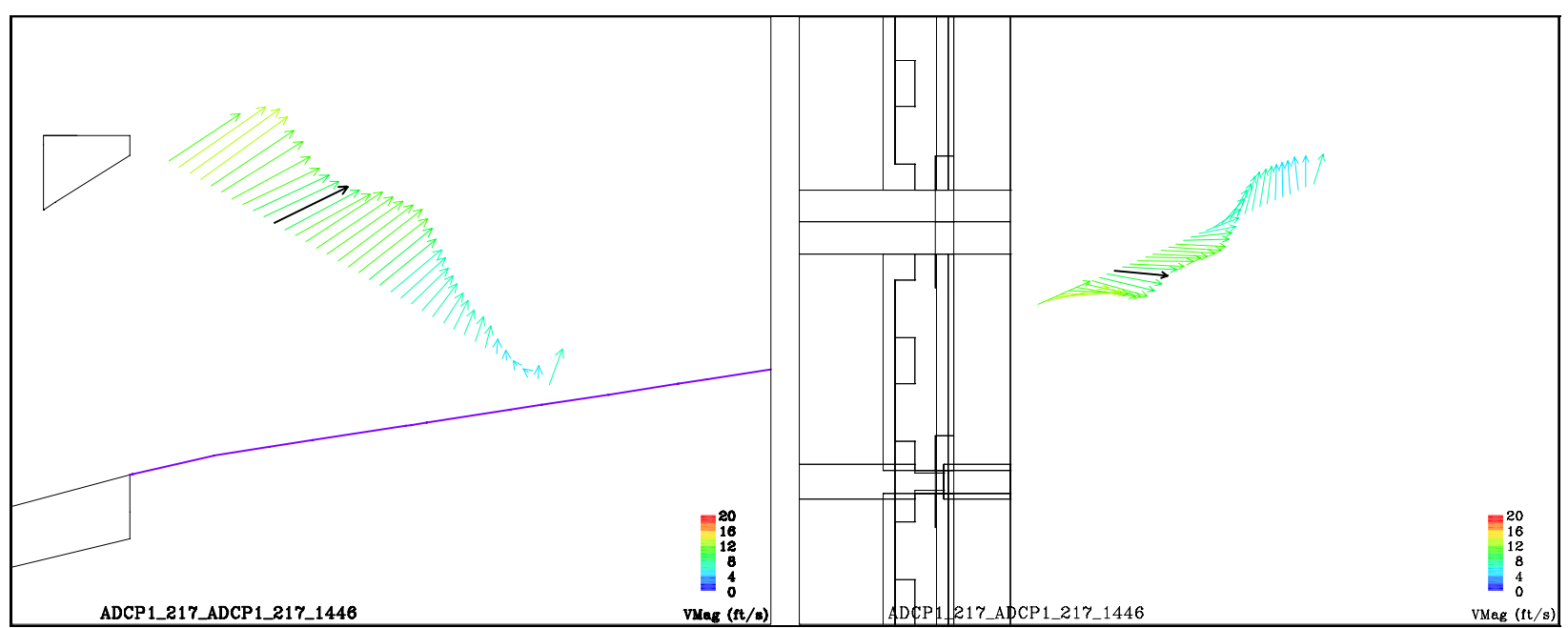

Figure 2.20. Side (left) and Plan (right) View of 3D Velocity Vectors for Data Collected by ADCP1 on February 17, 2005, for Approximately 10.5 Minutes Starting at 14:46 hours. The velocity vector $20 \mathrm{ft}$ from the transducer has been shaded in black (compare to Figures 2.17 and 2.18). 


\subsection{Acoustic Doppler Current Profiler Results}

This chapter describes results collected by both the mobile and powerhouse-mounted ADCPs. A compact disk (CD)also has been assembled to accompany this report. This CD contains all raw data files collected by the ADCPs and associated external equipment, summary mobile ADCP data values with associated statistics, and a standalone document that defines the coordinate system developed to describe the rotation angles of the powerhouse ADCP beams. ADCP files stored on the CD are labeled by time stamp (year, month, day, hour, minute, second) in order to facilitate sorting and unique identification.

\subsection{Mobile Data Collection}

This section presents results collected during the two days of mobile surveying (February 17 and 18, 2005). To improve readability, all graphics illustrating results from vessel-mounted ADCPs (both point and transect) can be found in Appendix A. Details of John Day Dam operations are documented in Appendix C.

\subsubsection{Day 1: February 17, 2005}

Spillbay gate openings were kept constant during the 6-hr test, which lasted from 10:00 hours until 16:00 hours. Total spillway discharge was approximately 10\% of the total river discharge. Output from GDACS during the sampling period shows that operations remained fairly constant (see Table 3.1). However, Unit 5 was switched on at 15:00 hours and Unit 7 was turned off. Data collected during this potential transition period can be identified in the database of reported velocity values by sorting values by time stamp.

The results of data collected by boat are shown in Appendix A. These maps show the overall tailrace zone; bathymetric contours were added to help put the flow field in context. Tailrace islands are shown in

Table 3.1. GDACS Summary of Project Operations from 10:10 hours Until 16:00 hours on February 17, 2005. Forebay and tailwater elevations are in feet MSL. Turbine unit (T) and spillway bay (S) discharges are in kcfs, and units/ bays not displayed were off.

\begin{tabular}{|c|c|c|c|}
\hline & average & $\max$ & notes \\
\hline forebay & 264.3 & 264.5 & 264.2 \\
\hline tailwater & 160.2 & 160.6 & 160.0 \\
\hline T03 & 15.2 & 16.9 & 14.4 \\
\hline T04 & 14.9 & 16.2 & 14.6 \\
\hline T05 & 2.5 & 17.1 & 0.0 (on at $15: 00$ ) \\
\hline T06 & 15.2 & 16.9 & 15.0 \\
\hline T07 & 12.6 & 15.7 & 0.0 (off at $15: 00$ ) \\
\hline T08 & 15.2 & 16.7 & 14.5 \\
\hline T09 & 15.2 & 16.9 & 15.1 \\
\hline T11 & 15.5 & 16.9 & 14.4 \\
\hline T14 & 15.0 & 16.6 & 14.3 \\
\hline T16 & 15.2 & 17.4 & 14.1 \\
\hline S02 & 4.9 & 5.0 & 4.9 \\
\hline S03 & 4.9 & 5.0 & 4.8 \\
\hline S04 & 3.1 & 3.1 & 3.1 \\
\hline s05 & 2.2 & 2.2 & 2.1 \\
\hline
\end{tabular}


white, and their shapes are approximately correct for the tailwater elevation during the sampling period. Three ADCP discharge measurements were collected during the period, and measured values are within $4 \%$ of the period average river discharge.

A close-up view of transecting data near the John Day Dam is shown on page A.3. Spillway bays and powerhouse units that were operational during the sampling are highlighted in blue. All transecting arrows represent depth-averaged magnitudes and directions.

Point data measurements are shown on page A.4. Although the ADCP was configured to collect 0.5 -m depth bins, only the bin closest to the labeled arrow depth (e.g., red $=10 \mathrm{ft}$, green $=20 \mathrm{ft}$ ) is shown for clarity. Arrows are placed on the figure so that higher-magnitude arrows are below lower-magnitude arrows and no arrows are completely covered. Point labels shown on page A.5 are provided to facilitate identification of tabular results shown in Appendix B.

\subsubsection{Day 2: February 18, 2005}

As on the previous day, spillbay gate openings were kept constant during the 6-hr test, which lasted from approximately 10:30 hours until 16:00 hours. Total spillway discharge was increased from the previous day to approximately $20 \%$ of the total river discharge. GDACS output (see Table 3.2 ) from the sampling period show that operations remained fairly constant.

Mobile transecting data are shown in Appendix A on pages A.6 and A.7 (close-up). Mobile ADCP discharge data are within $4 \%$ of the average dam discharge during the period.

The percentage of flow on the north versus south side of the island (i.e., flow split) changed between the two study days. On the lower spillway discharge Day 1 , the flow split was $42 \%$ north versus $58 \%$ south. On the higher spillway discharge Day 2 , the flow split was approximately equal. It should be noted, however, that total river discharge was $20 \%$ less on the day of higher spillway discharge (123 versus $152 \mathrm{kcfs}$ ).

Table 3.2. GDACS Summary of Project Operations from 10:20 hours Until 16:10 hours on February 18, 2005. Forebay and tailwater elevations are in feet MSL. Turbine unit (T) and spillway bay $(\mathrm{S})$ discharges are in $\mathrm{kcfs}$, and units/ bays not displayed were off.

\begin{tabular}{|c|c|c|c|}
\hline \multirow{3}{*}{$\begin{array}{r}\text { forebay } \\
\text { tailwater }\end{array}$} & average & $\max$ & $\min$ \\
\hline & 264.3 & 264.6 & 264.1 \\
\hline & 159.6 & 160.1 & 159.2 \\
\hline T03 & 14.0 & 14.5 & 13.6 \\
\hline T05 & 13.9 & 14.4 & 13.5 \\
\hline T07 & 14.0 & 14.6 & 12.9 \\
\hline T09 & 13.6 & 13.7 & 13.5 \\
\hline T11 & 13.6 & 13.8 & 13.5 \\
\hline T14 & 14.0 & 14.6 & 13.8 \\
\hline T16 & 14.2 & 14.6 & 14.1 \\
\hline S02 & 4.6 & 4.7 & 4.6 \\
\hline S03 & 4.6 & 4.7 & 4.6 \\
\hline S04 & 4.6 & 4.6 & 4.5 \\
\hline S05 & 3.2 & 3.2 & $\overline{3.1}$ \\
\hline S06 & 3.3 & 3.4 & 3.3 \\
\hline S07 & 3.4 & 3.5 & 3.4 \\
\hline S08 & 1.7 & 1.8 & 1.7 \\
\hline
\end{tabular}


Point data measurements are shown on page A.8. Point labels shown on page A.9 are provided to facilitate identification of tabular results shown in Appendix B. Raw WinRiver and processed mobile data were delivered via CD to the Portland District, USACE.

\subsection{Powerhouse-Mounted Data Collection}

Along-beam ADCP data were collected inside and downstream of the Unit 16 draft tube exits during the mobile ADCP data collection period (February 17 and 18) plus on three successive days (February 22, $23,24)$ during which Unit 16 was operated at low, medium, and high discharge. Because the ADCP units collected data at a rate of $1.33 \mathrm{~Hz}$ (i.e., profile collected every $0.75 \mathrm{sec}$ ), the quantity of data collected during these five days is large. Processing and reporting of these data has been organized by research question and is neither chronological nor inclusive of all data that were collected. These data have been organized in this way to best answer several questions posed by the Portland District, USACE, and to show the feasibility of using ADCPs to directly measure hydraulic phenomena in this zone.

Although three ADCPs were deployed by divers on February 15, only two of the units collected meaningful data. Communication with the north 6-degree ADCP (closest to Unit 17) was lost soon after Unit 16 was started. When divers attempted to retrieve the ADCP, the dual-axis rotator (RJ rotator, see Figure 2.4) was discovered to have come apart, and the ADCP and rotator were not retrieved. The south 6-degree ADCP produced useful data on February 17 and 18. However, this rotator failed over the weekend, and useful data could not be collected by this ADCP the following week. The center 20-degree ADCP and rotator worked flawlessly during the entire two-week study. Because the center and south rotators were identical, it is hypothesized that the center ADCP was partially shielded from hydraulic forces because it was mounted above the Unit 16 dividing wall. After reviewing the GDACS data, it was noted that sudden shifts in the south ADCP during February 17 and 18 correspond to times when discharge through Unit 16 was changing. This coincidence may indicate the presence of violent boils that erupt through the draft tube during discharge changes.

\subsubsection{D Velocity Measurements}

Velocity data collected by the 6-degree ADCP covered only a small range of Unit 16 discharge capacity; $15.5 \mathrm{kcfs}$ on February 17 and $14.2 \mathrm{kcfs}$ on February 18. During both days, ADCP1 (south ADCP closest to Unit 15; see Figure 2.6) collected data through a range of angles, stopping at each location for several minutes to collect data. Each of these profiles has been summarized using three views (front, plan, and side), which can be found in Appendix B.

The complete collection of 3D measurements made at Unit 16 when the discharge was $14.2 \mathrm{kcfs}$ is shown in Figure 3.1. The ADCP was swept through a large side-to-side sweep throughout the sampling period, allowing for the computation of discharge (see Section 3.2.2).

Velocity vectors within $\pm 8 \mathrm{ft}$ of the Barrel Exit A were interpolated onto a uniform planar grid. The velocity vectors were then decomposed into $\mathrm{X}, \mathrm{Y}$, and $\mathrm{Z}$ components, representing directions horizontal and pointing out of the draft tube, horizontal and pointing lateral to the powerhouse face, and vertical, respectively. These velocity components were then colored by magnitude and are shown in Figure 3.2.

The flow field out of the draft tube exit is highly non-uniform in all the three directions across the plane. The maximum X velocity is along the south side of the draft tube barrel, closest to Unit 15 (see 


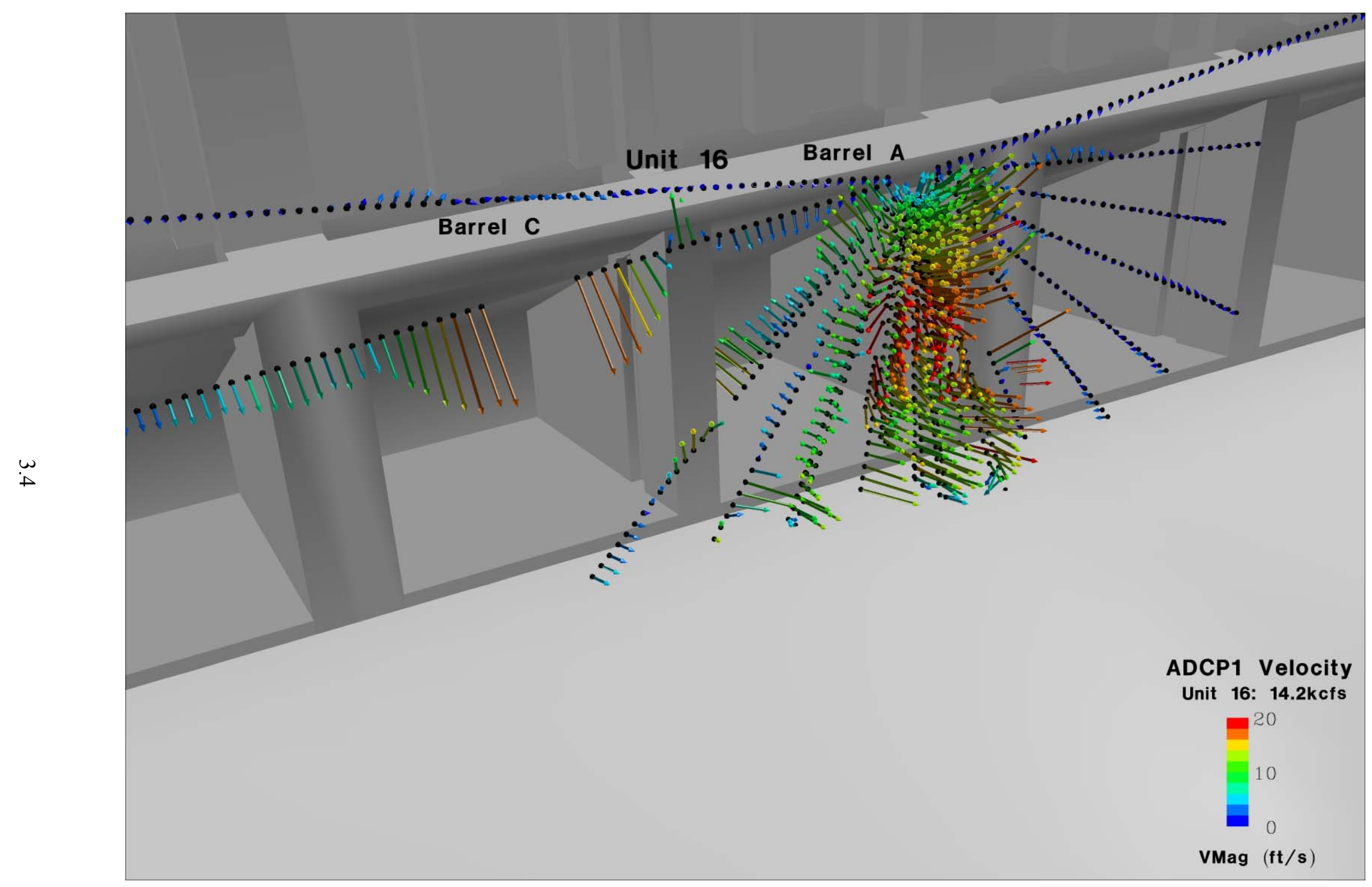

Figure 3.1. Collection of Velocity Vectors Measured by the South 6-Degree ADCP When the Reported Turbine Discharge Was Approximately $14.2 \mathrm{kcfs}$ (February 18, 2005) 


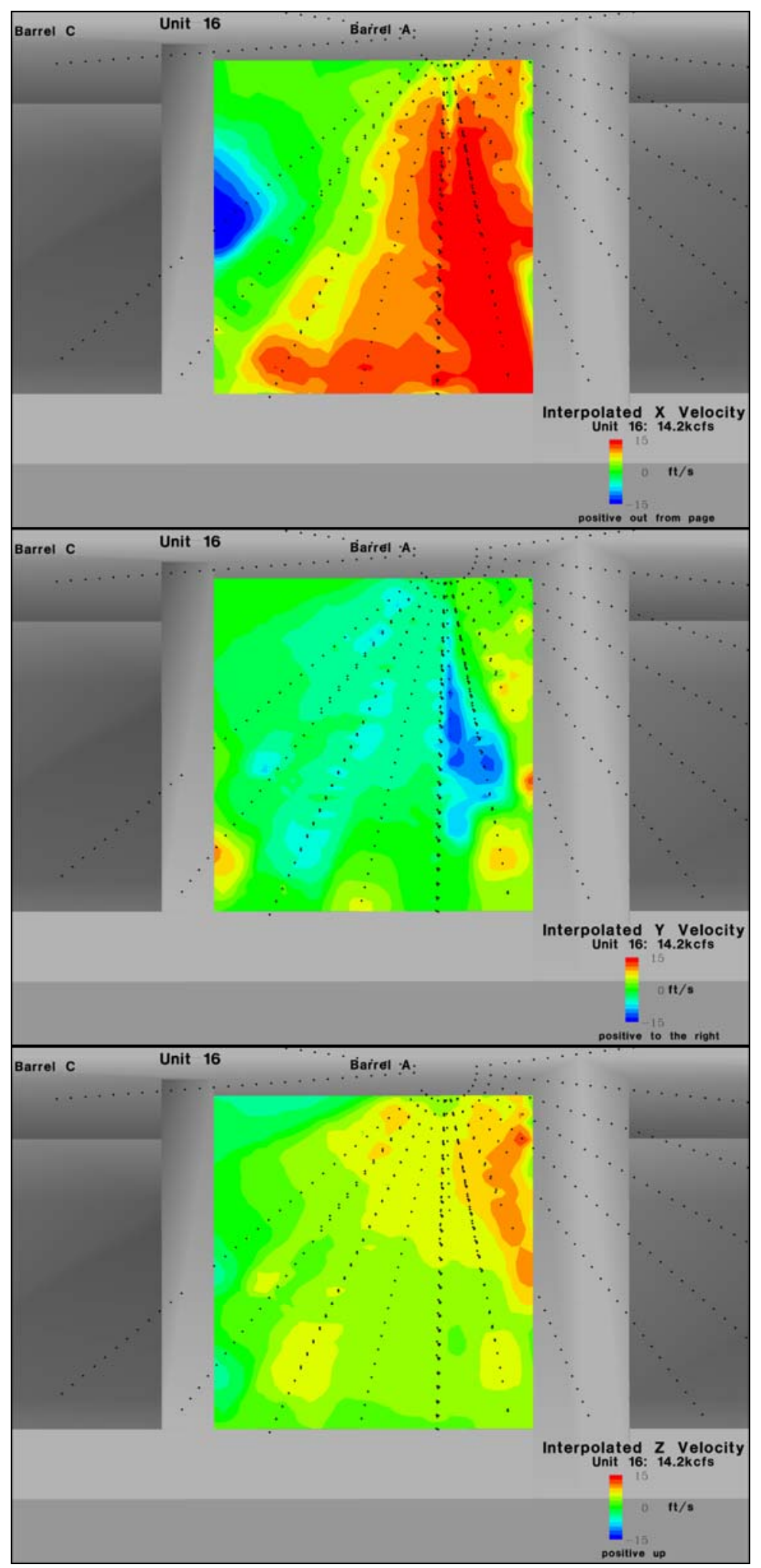

Figure 3.2. Three Cartesian Components of Velocity at the Draft Tube Exit (discharge $=14.2 \mathrm{kcfs})$ 
Figure 3.5). $X$ velocities decrease as one travels to the opposite side of the draft tube, and some negative values were detected. The $\mathrm{Y}$ and $\mathrm{Z}$ velocity component patterns are equally complex across the exit.

The complete collection of 3D measurements made at Unit 16 when the discharge was $15.5 \mathrm{kcfs}$ is shown in Figure 3.3. During the sampling period, the ADCP was articulated out and back from the tailrace to the draft tube exit. This allowed for computation of velocity decay with distance from the draft tube exit (see Section 3.2.3).

As before, velocity vectors $\pm 8 \mathrm{ft}$ of the Barrel Exit A were interpolated onto a uniform planar grid. Because the sweep did not cover the entire exit, only part of the draft tube was covered. This limited data set does cover the higher-velocity zone, and distinct differences between the $14.2 \mathrm{kcfs}$ and $15.5 \mathrm{kcfs}$ velocity patterns were noted.

\subsubsection{Feasibility of Discharge Measurements}

Because of the narrow beam spread, this project investigated the feasibility of computing discharge using a 6-degree ADCP. Before discharge was computed, the homogeneity of the individual 3D velocity vectors was investigated to determine if this computation was reasonable. After the data were examined, it appears that at most measured locations the homogeneity was within acceptable limits. Velocity vectors with a homogeneity index (see Section 2.3.4) larger than $0.7 \mathrm{ft} / \mathrm{s}$ were removed. The resulting collection of points was then used to compute the discharge.

Discharge was computed by integrating the $\mathrm{U}$ velocity component (X direction, see upper part of Figure 3.2) over the draft tube exit, and the flow field is shown in Figure 3.5. The resulting measured discharge for the barrel was $9.5 \mathrm{kcfs}$. During the discharge period, the GDACS-recorded discharge for Unit 16 was $14.3 \mathrm{kcfs}$. This corresponds to a flow split of discharge between the two barrels of $67 \%$ for Barrel A and 33\% for Barrel C.

This flow split can be compared to the flow split computed using the 1:25 scale model of Lower Granite Dam, which has similar structural geometry. At a discharge of $17.6 \mathrm{kcfs}$, the physical model computed a discharge of 70\% for Barrel A and 30\% for Barrel C (Davidson 2004).

\subsubsection{Decay of Velocity Magnitude with Distance Away from Draft Tube Exit}

One of the objectives for this project was to collect velocity information near the draft tube exit for use in calibrating physical and numerical models of the tailrace. These models must assign boundary condition information at these regions, and improper specification of velocity magnitudes and directions has the potential to impact downstream results.

The narrow beam-spread 6-degree ADCP1 was used to collect velocity information with distance from the draft tube on February 17 and 18. Unfortunately, the ADCP was not swept fully across the entrance and out into the tailrace under the exact same discharge conditions. Between the two days, this zone was covered, but the discharge varied between 14.2 and $15.5 \mathrm{kcfs}$. This can be seen most clearly by comparing Figures 3.2 and 3.4. However, for this section, these differences were ignored in order to put the general circulation pattern in context.

The decay of velocity magnitude with distance from the exit is shown in $3 \mathrm{D}$ perspective in Figures 3.6 and 3.7. The data on lateral plane velocities at the draft tube exit are from February 18 


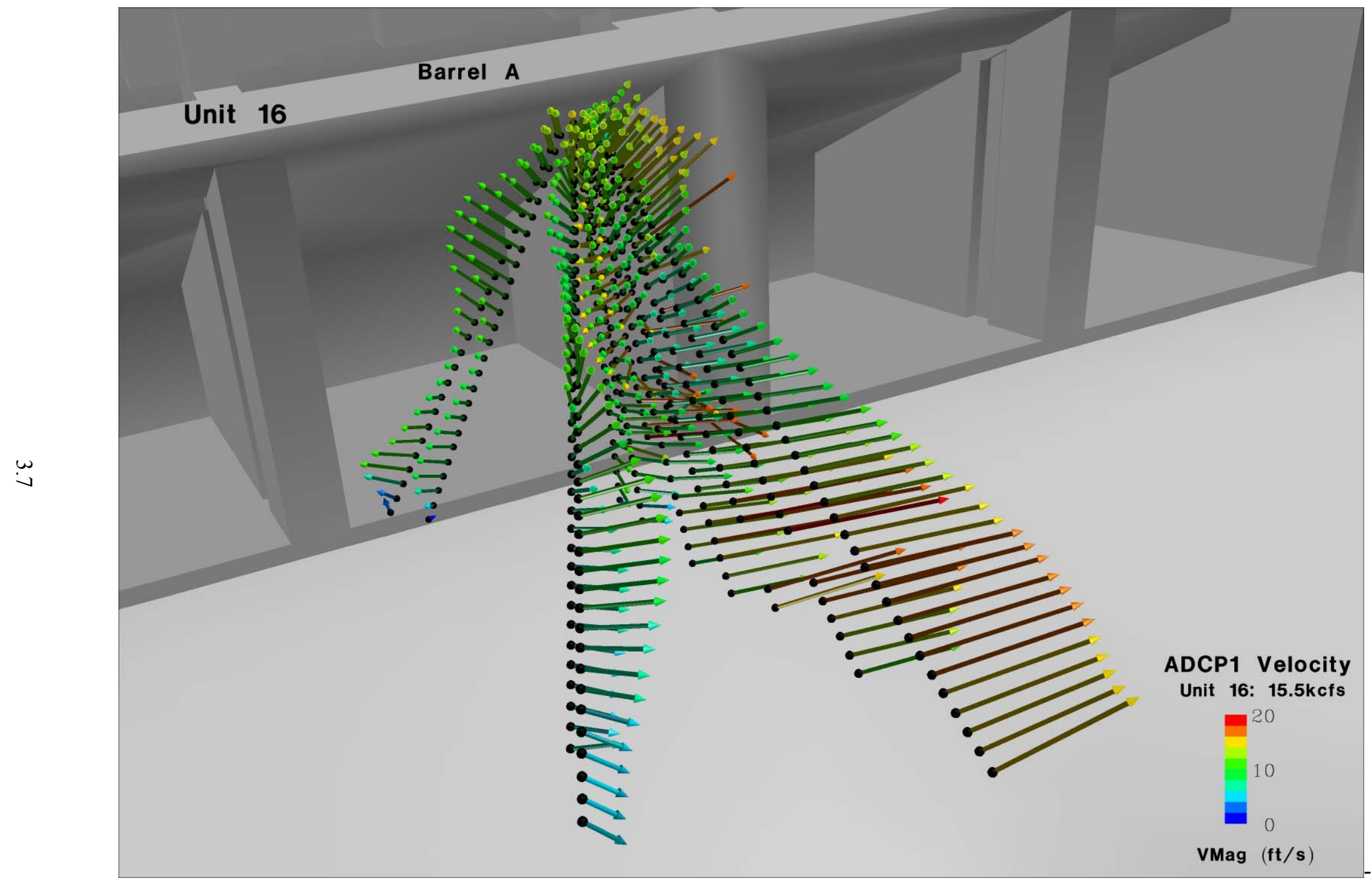

Figure 3.3. Collection of Velocity Vectors Measured by the South 6-Degrees ADCP When the Reported Turbine Discharge Was Approximately 15.5 kcfs (February 17, 2005) 


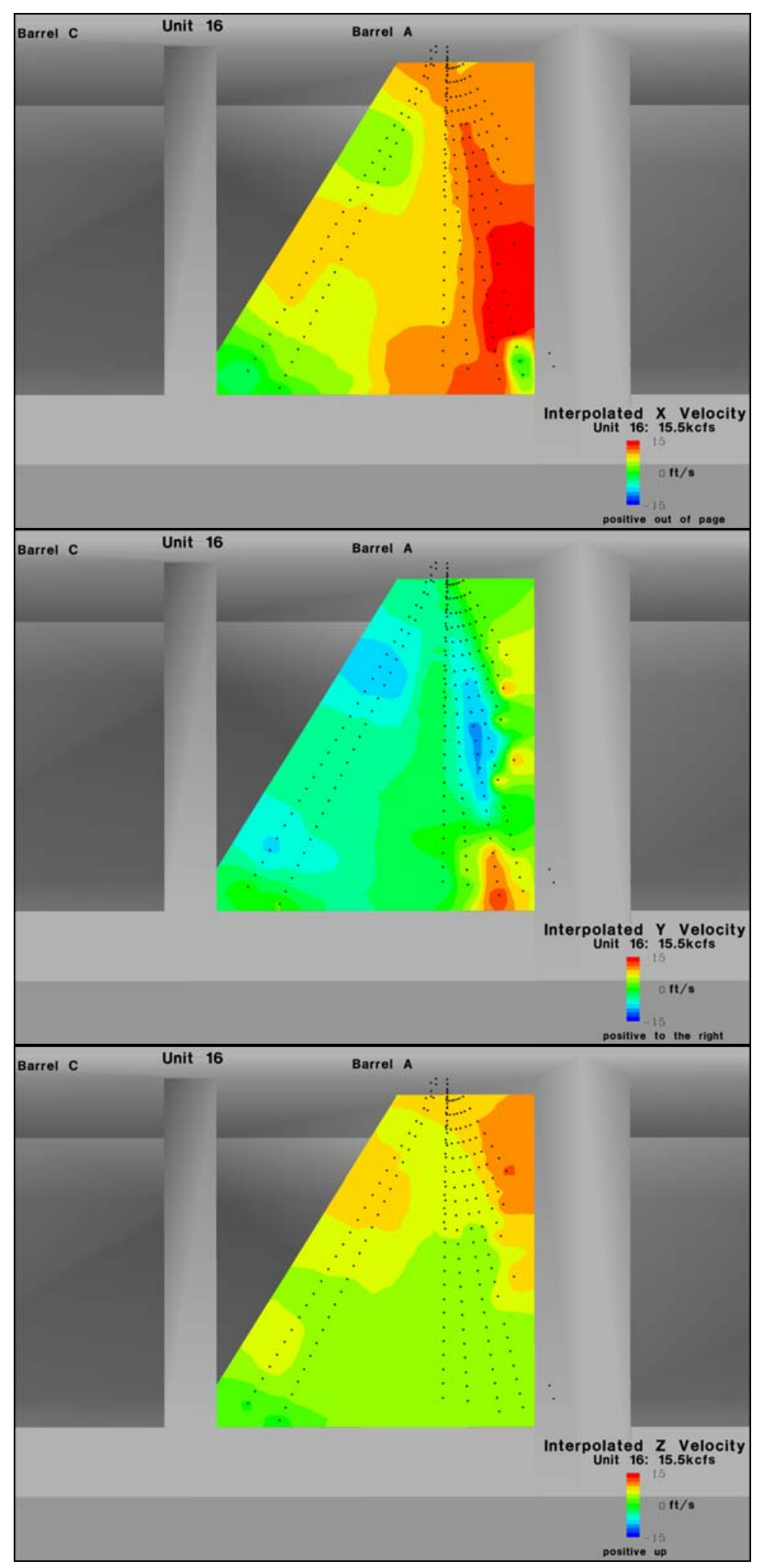

Figure 3.4. Three Cartesian Components of Velocity at the Draft Tube Exit (discharge $=15.5 \mathrm{kcfs}$ ). Contours have been blanked in zones where supporting data were not available. 
Unit 16 at $14.2 \mathrm{kcfs}$, Barrel $A$

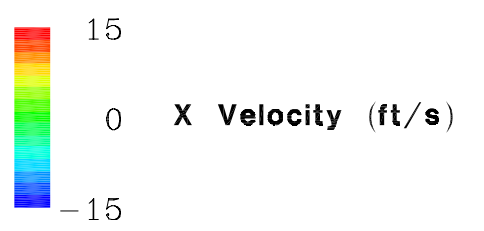

Computed Barrel A Discharge: 9.5kcfs Barrel Split: A - 67\%, C - 33\%

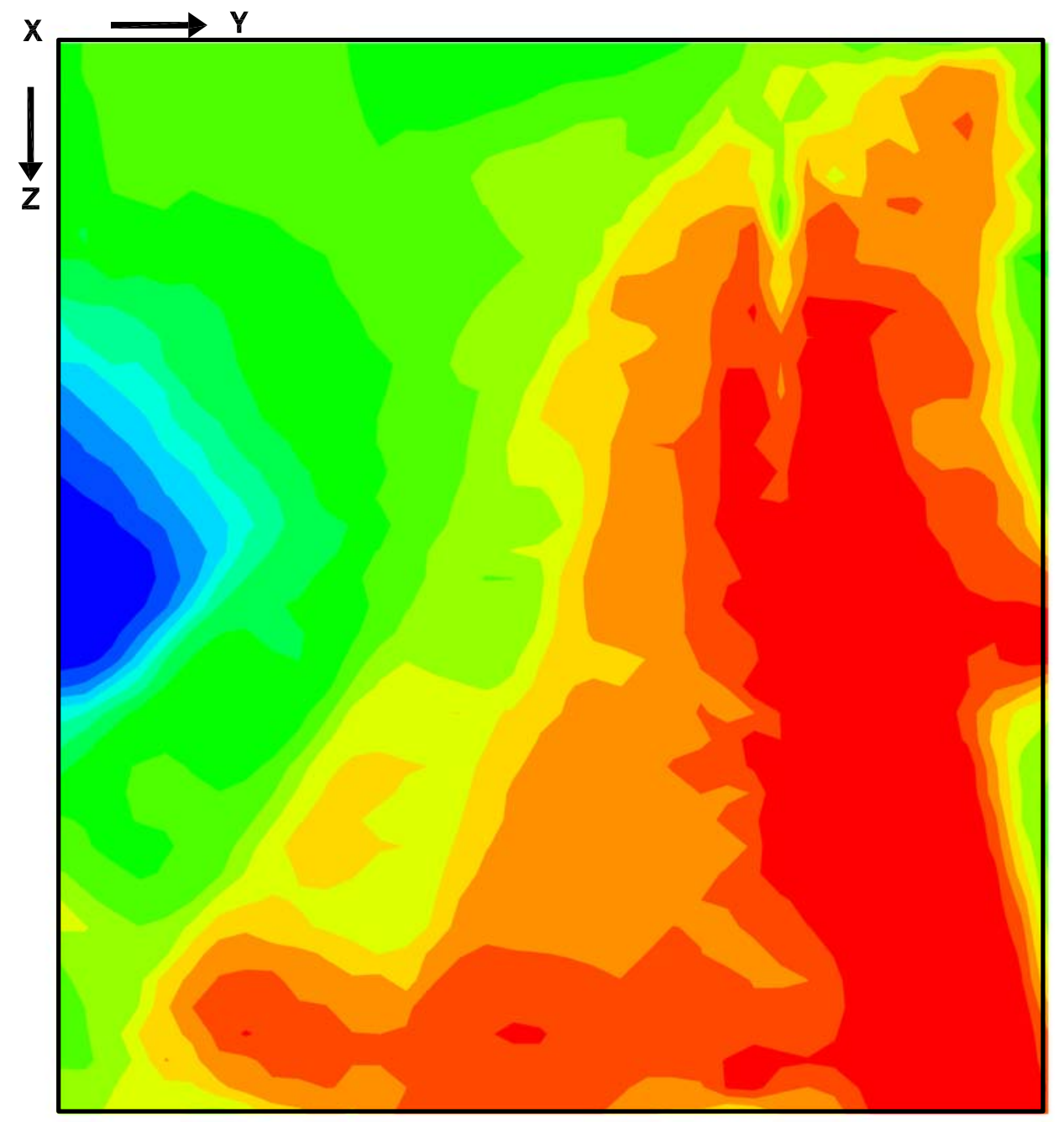

Barrel A exit, looking upstream

Figure 3.5. $\quad$ Measured X Velocity Component and the Resulting Discharge for Unit 16, Barrel A. The density of collected ADCP data used to compute this discharge measurement can be seen by examining the upper graphic (X component) of Figure 3.2. 


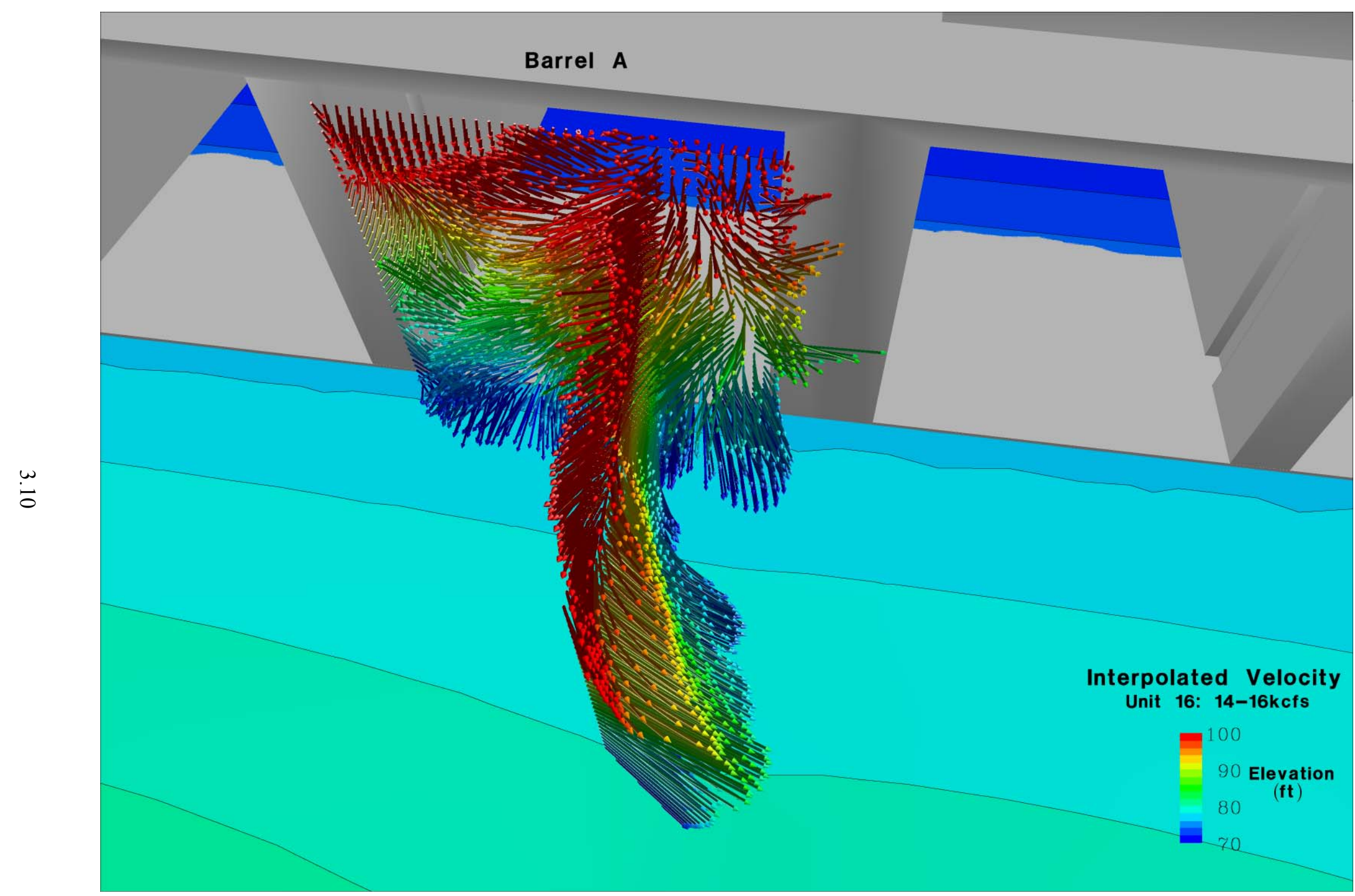

Figure 3.6. $\quad 3 \mathrm{D}$ Velocity Vectors Exiting the Draft Tube. Vectors have been shaded by elevation, but length is proportional to magnitude. 


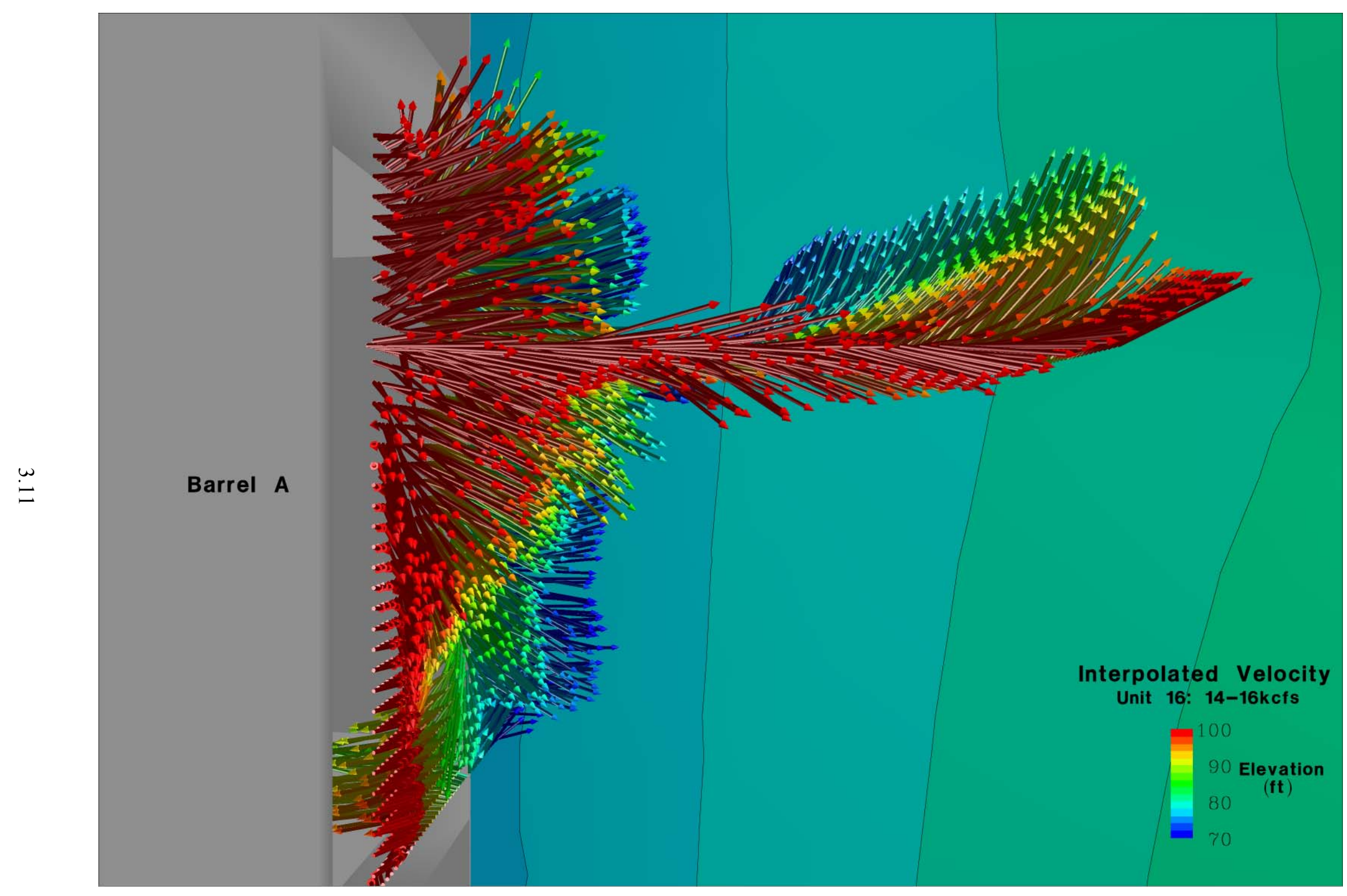

Figure 3.7. 3D Velocity Vectors Exiting the Draft Tube. Vectors have been shaded by elevation, but length is proportional to magnitude. 
(14.2 kcfs), and the data on the longitudinal plane of velocities into the tailrace are from February 17 $(15.5 \mathrm{kcfs})$. The length of each arrow is proportional to velocity magnitude; however, the arrows have been shaded by elevation to help illustrate the depth variation in both magnitude and direction of the exiting jet.

With distance away from the draft tube exit, the velocity vectors in the upper part of the water column turn only slightly as they progress downstream. In the bottom of the water column, water exiting the draft tube quickly encounters the upwardly sloping bathymetry. Velocity vectors appear to turn toward Unit 15 , and as the jet is compressed in height, these vectors also experience little decrease in magnitude between the exit and at distance.

Changes in velocity magnitude can be seen more easily by examining slices of 3D vectors at set elevations shown in Figures 3.8 through 3.11. These slices are at elevations of 75, 85, 90, and $105 \mathrm{ft}$. Bathymetry has been shaded as before by elevation. These slices show the distinctive twist of the jet at the lower elevations; however, the twist decreases in intensity going upward. At elevation $105 \mathrm{ft}$, only a slight turn toward Unit 15 is noted, and most of the velocities are heading directly out and into the tailrace.

\subsubsection{Along-Beam Velocities Near the Draft Tube Exit}

Along-beam measurements represent 1D scalar velocity values in the direction of the beam. The reported values are either positive or negative, indicating flow moving either toward or away from the ADCP head. Some practical uses for along-beam velocities are 1) to compare variations over range a of discharge values to illustrate zones of change; 2) to compare RMS velocity fluctuations and to illustrate

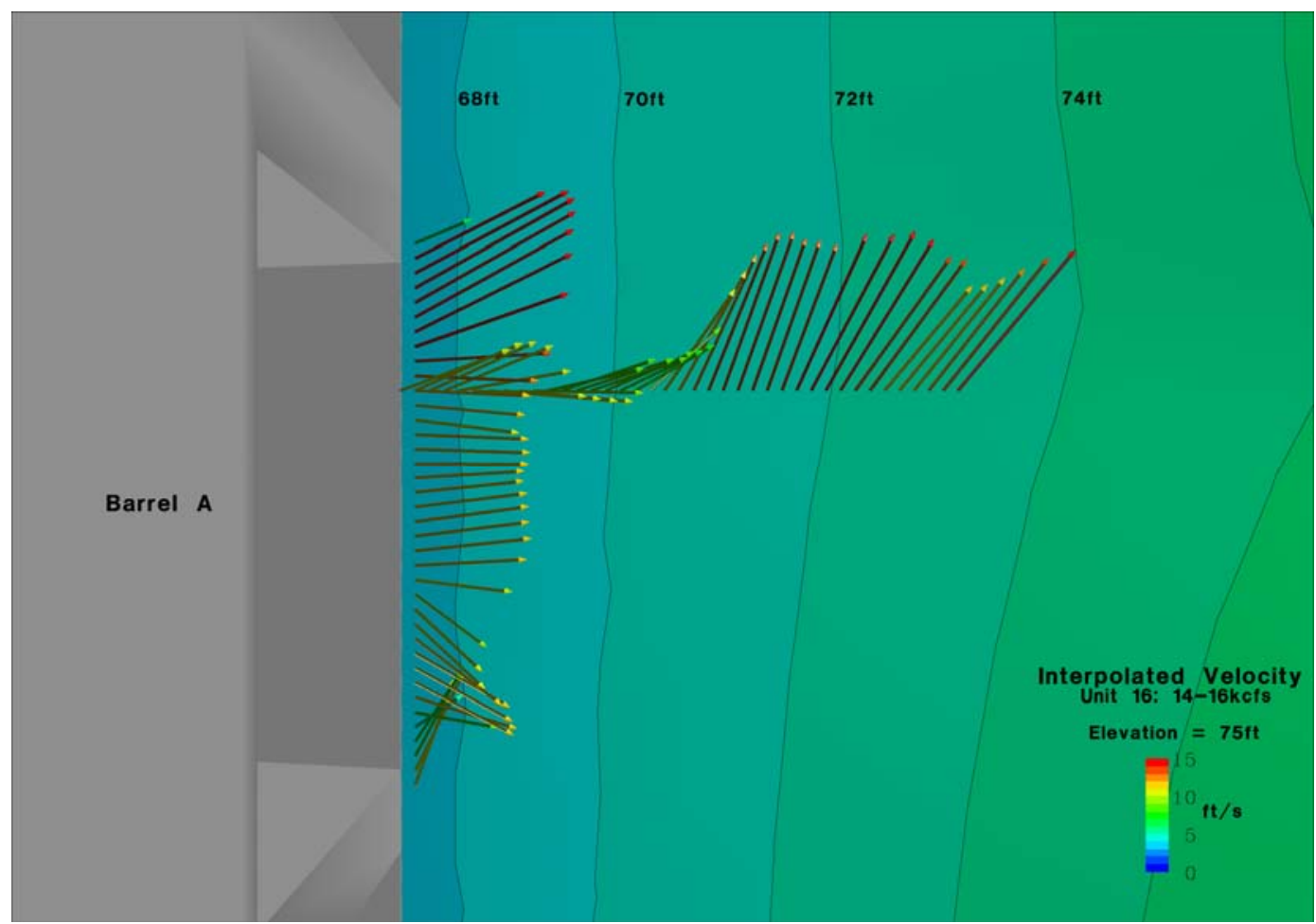

Figure 3.8. Velocity Vectors at Elevation $75 \mathrm{ft}$. Vectors shaded by magnitude. 


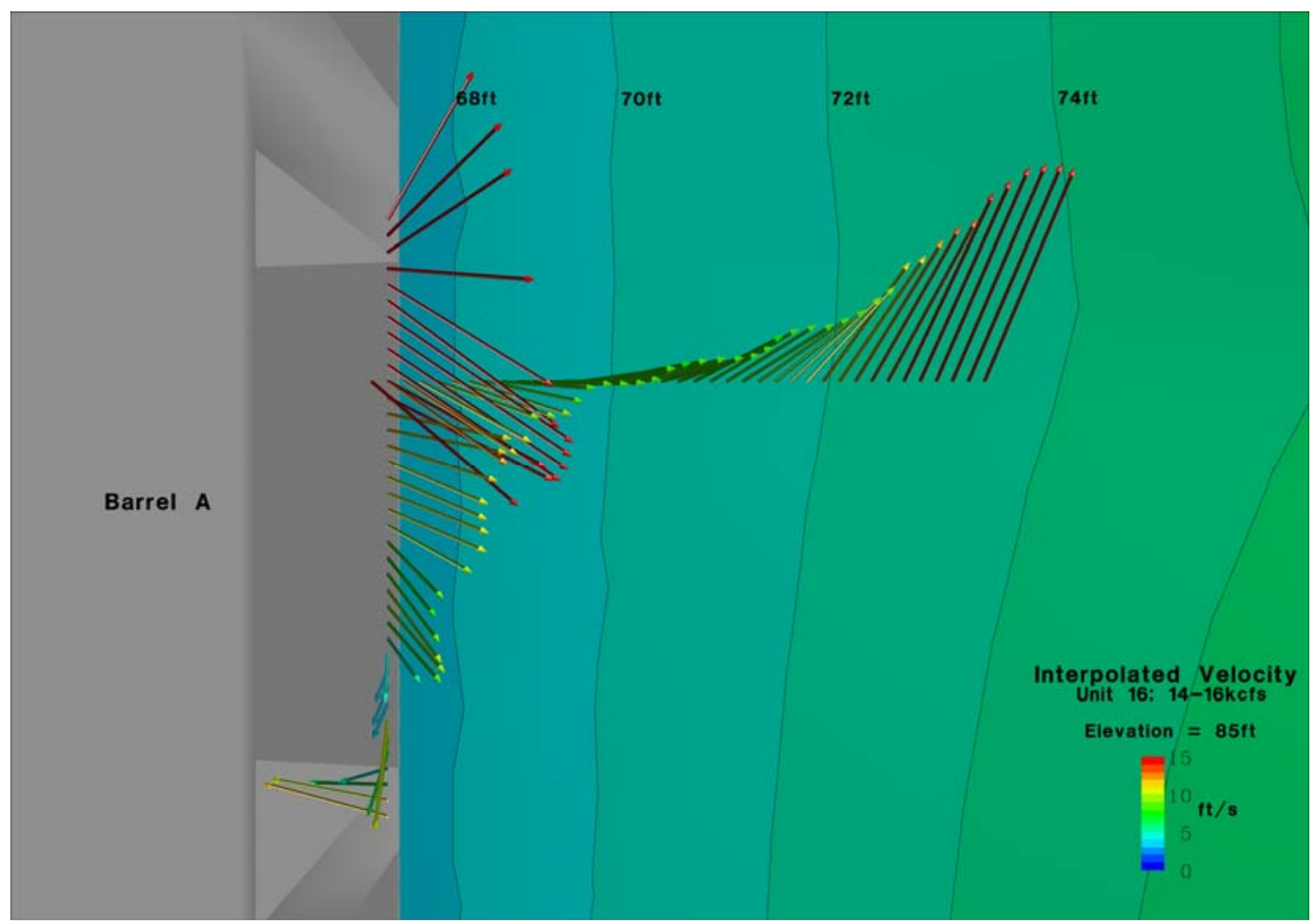

Figure 3.9. Velocity Vectors at Elevation $85 \mathrm{ft}$. Vectors shaded by magnitude.

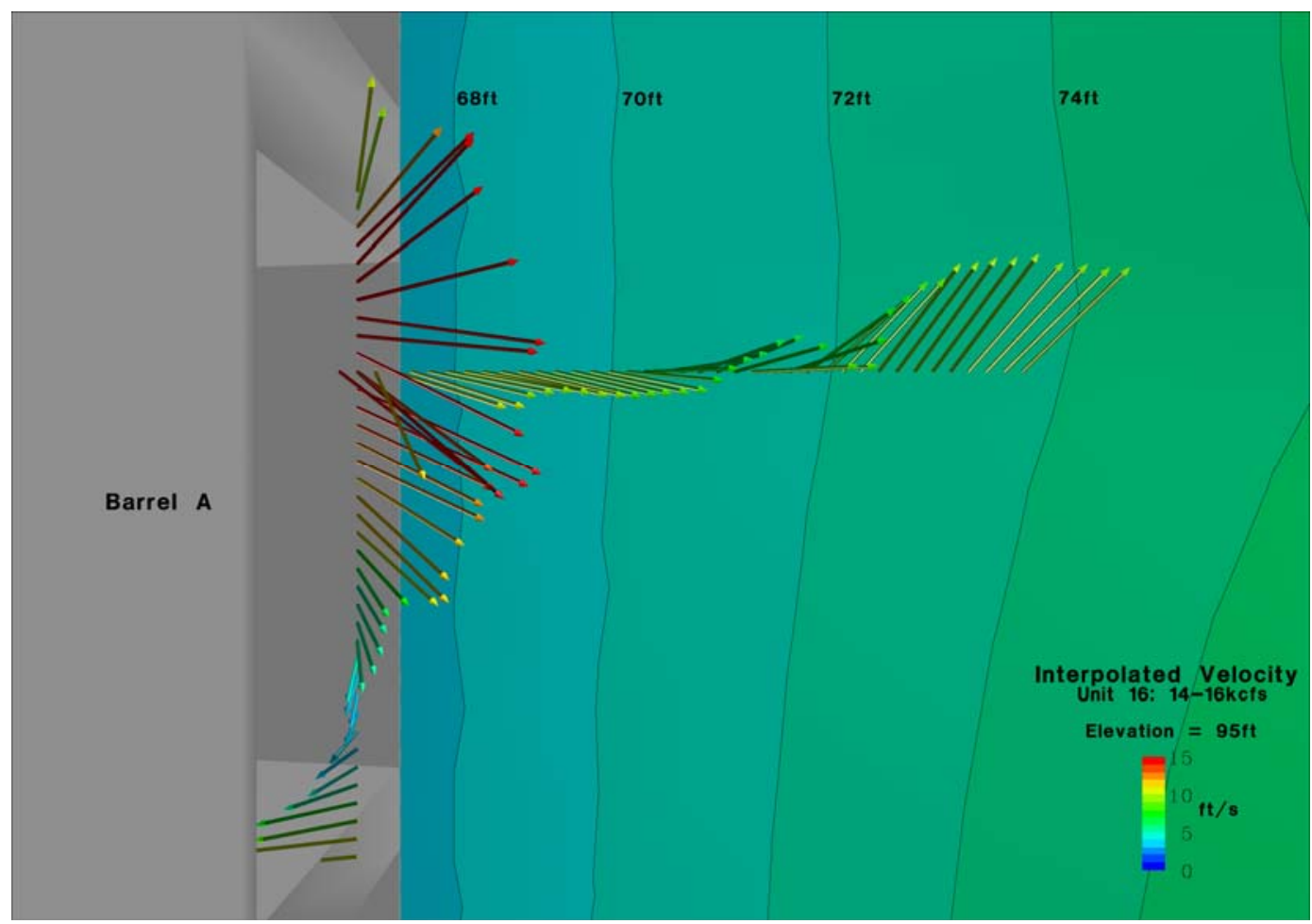

Figure 3.10. Velocity Vectors at Elevation $95 \mathrm{ft}$. Vectors shaded by magnitude. 


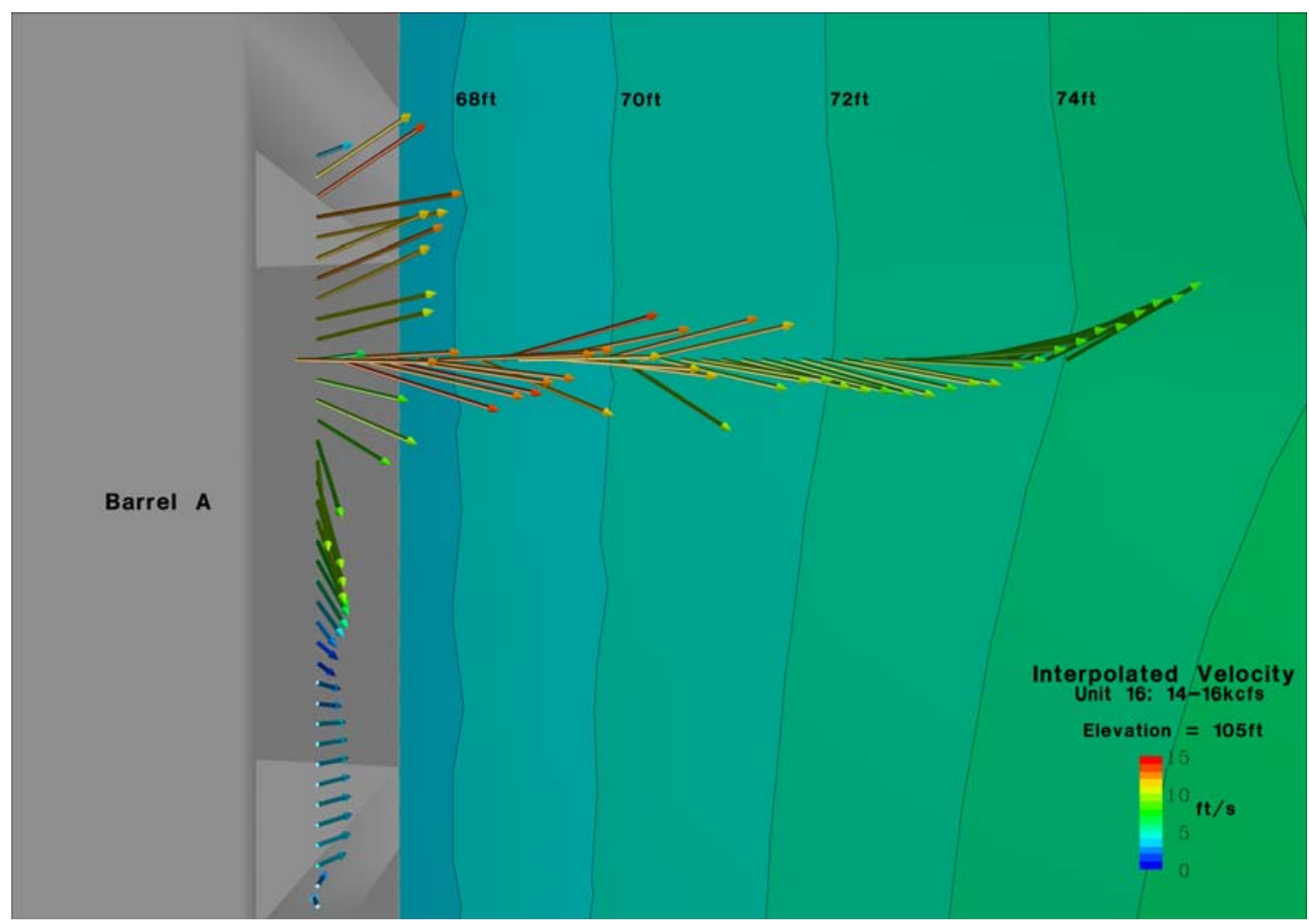

Figure 3.11. Velocity Vectors at Elevation $105 \mathrm{ft}$. Vectors shaded by magnitude.

zones where large changes occur as turbine discharge changes; and 3) to compare similar component values to either numerical or physical model results (see Section 2.3.2).

The results presented in this section compare along-beam velocities using the center 20-degree ADCP. This ADCP was rotated through prescribed sweeps (see Figure 3.12) over three turbine discharges. These sweeps were approximately identical and occurred at Unit 16 turbine discharges of 12, 16 , and $19 \mathrm{kcfs}$.

The along-beam velocities are shown in Figure 3.13. This series of three graphics illustrates the large change in along-beam velocity over the discharge range. The RMS velocity fluctuations, following the procedure described in Section 2.3.4, were also computed for each beam. These RMS velocity fluctuations can be compared by examining Figure 3.14. A large difference in RMS velocity fluctuations was noted for the 12-kcfs discharge in Barrel $\mathrm{C}$ as compared to the other barrels and discharges.

\subsubsection{Along-Beam Velocities Downstream of the Draft Tube Exit}

As in Section 3.2.4 above, this section describes along-beam velocities collected using the center 20-degree ADCP (see Figure 2.7). This section is different because of how the ADCP was articulated during the study (see Figure 3.15). These rotations were conducted so that the ADCP would point slightly upward and into the tailrace.

The along-beam velocity magnitudes are much larger than those reported in Section 3.2.4 because the main flow direction of the discharge jet was aligned with the beam. Along-beam velocities were noted to increase dramatically when discharge was increased from $12 \mathrm{kcfs}$ to $19 \mathrm{kcfs}$. 


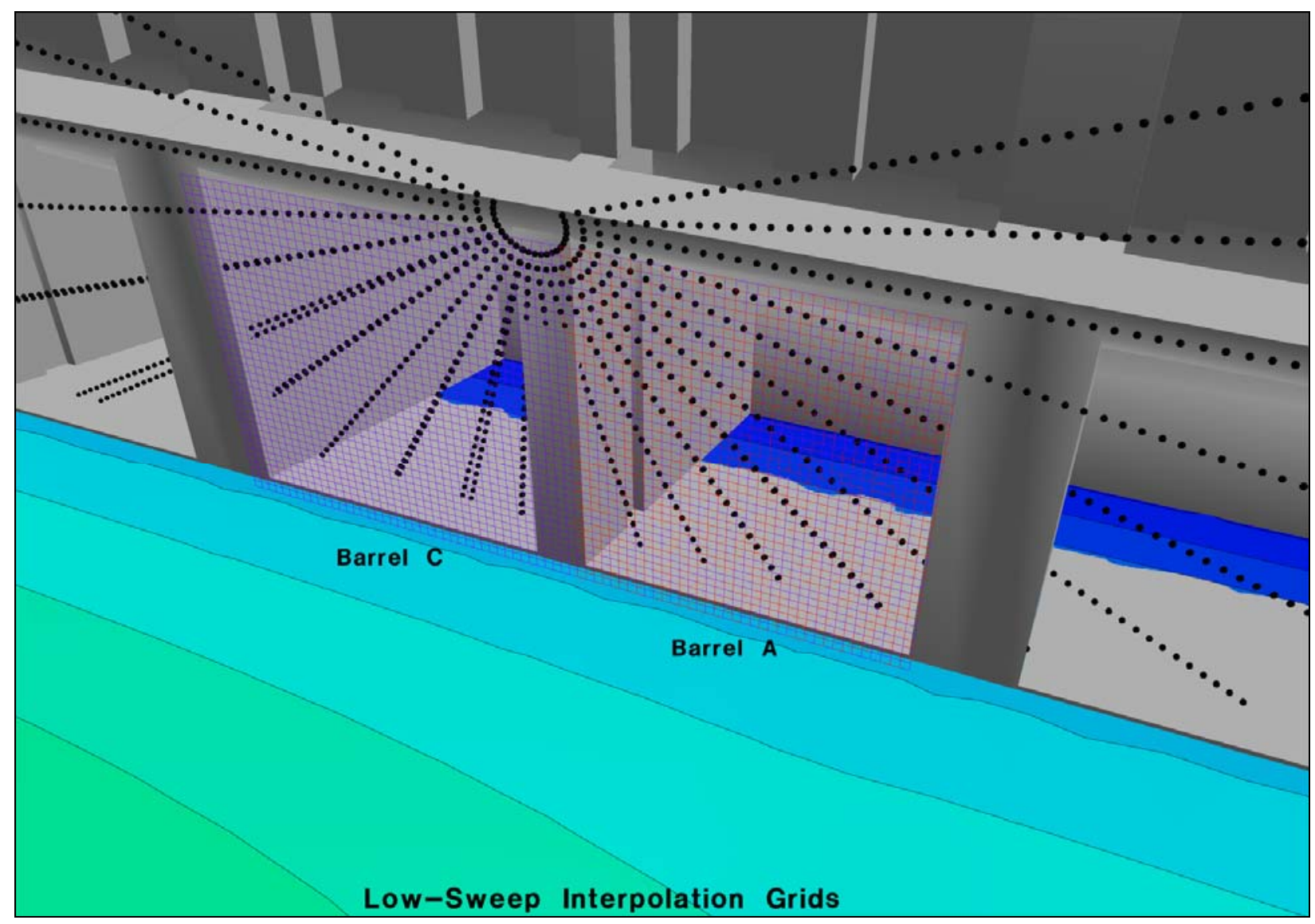

Figure 3.12. Measurement Points (black dots) and the Interpolation Grid Used to the Generate AlongBeam Velocity and RMS Velocity Fluctuation Figures

The RMS velocity fluctuations were generally smaller along this sweep than for the near-exit sweeps reported in Section 3.2.4. Local areas of high RMS velocity fluctuation were noted near the draft tube exit, but these tended to decay with distance away from the exit. 


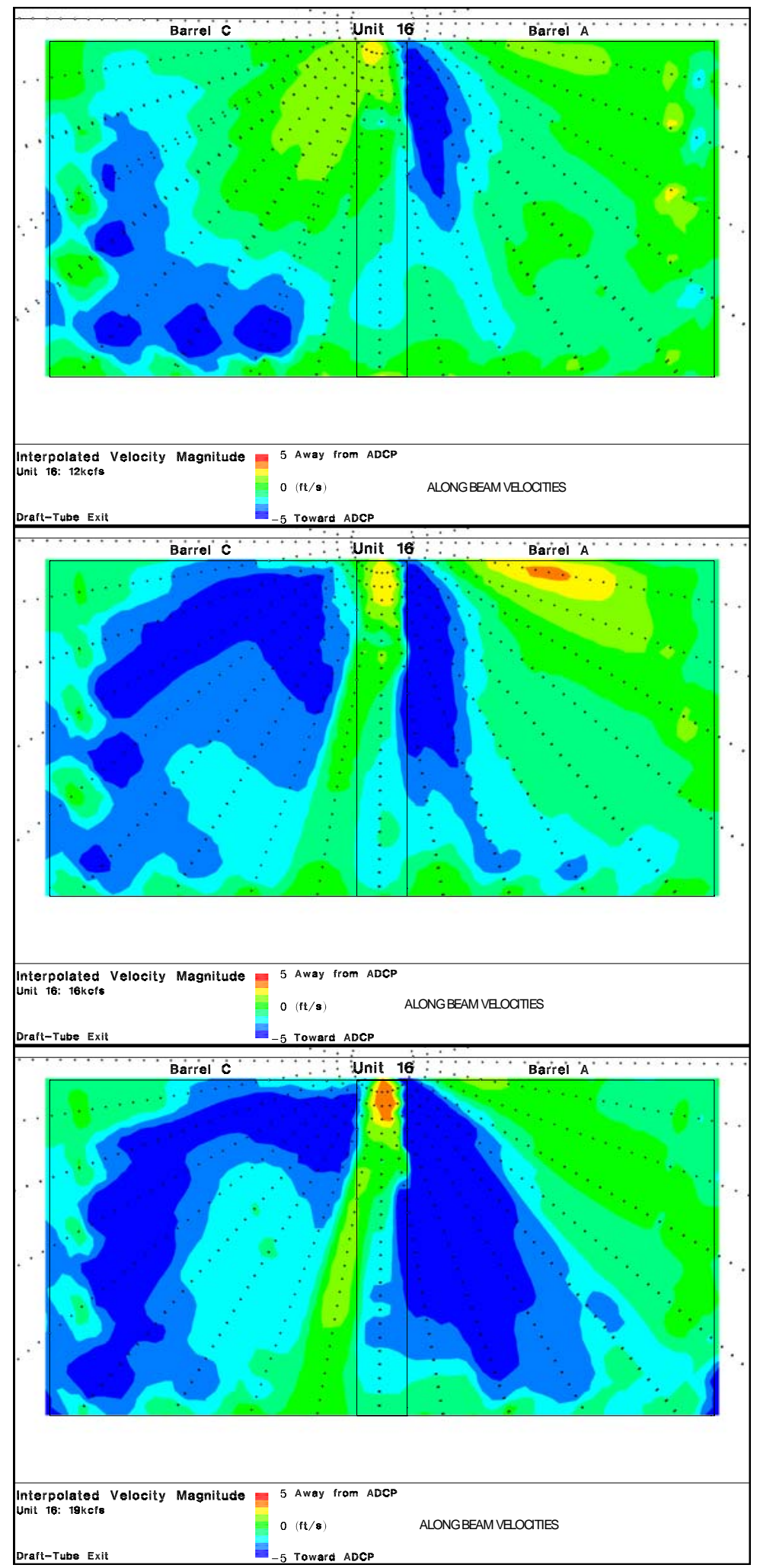

Figure 3.13. Along-Beam Velocity Magnitudes at Low (top), Medium (center), and High Discharge (bottom). Black dots indicate measurement locations. 


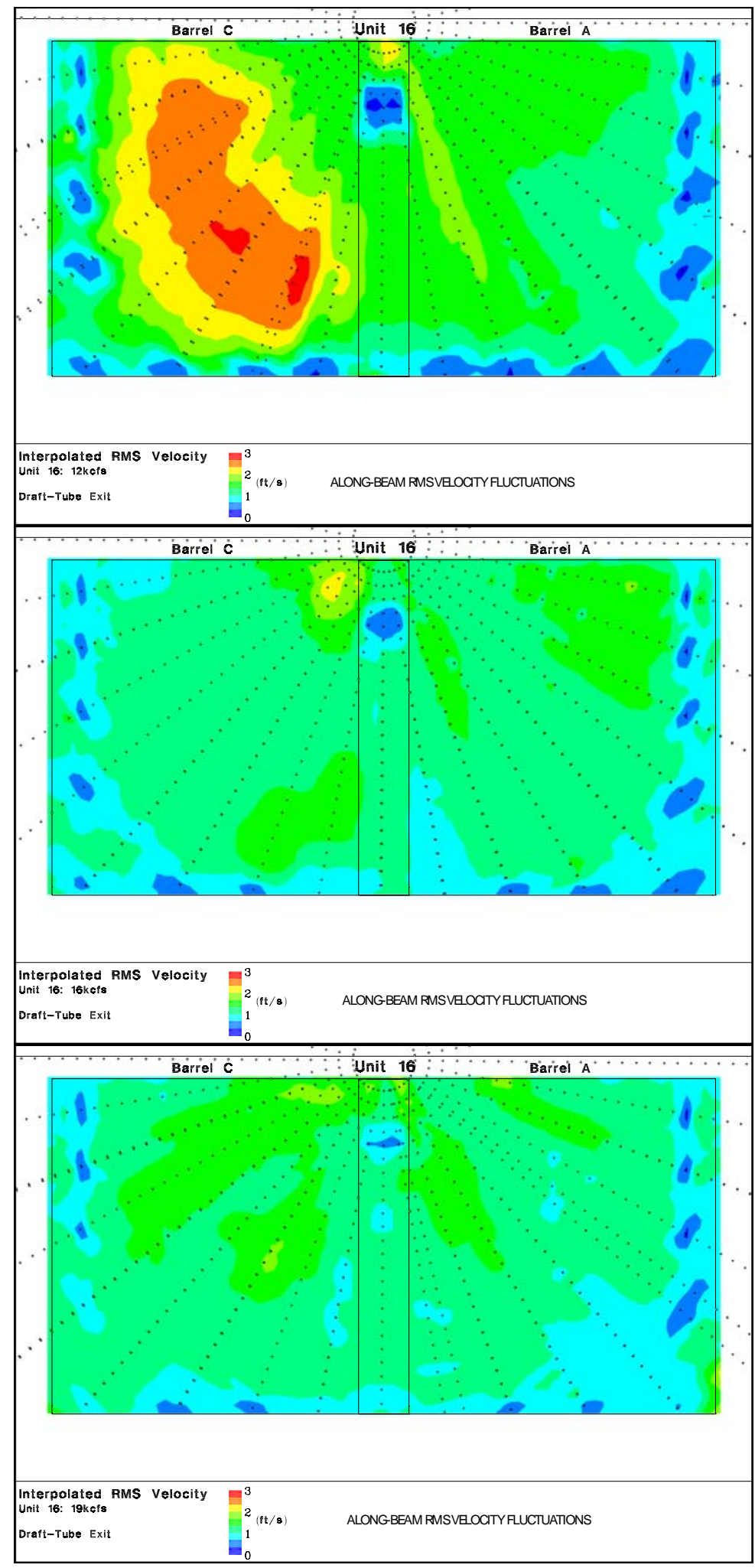

Figure 3.14. Along-Beam RMS Velocity Fluctuations at Low (top), Medium (center), and High Discharge (bottom). Black dots indicate measurement locations. 


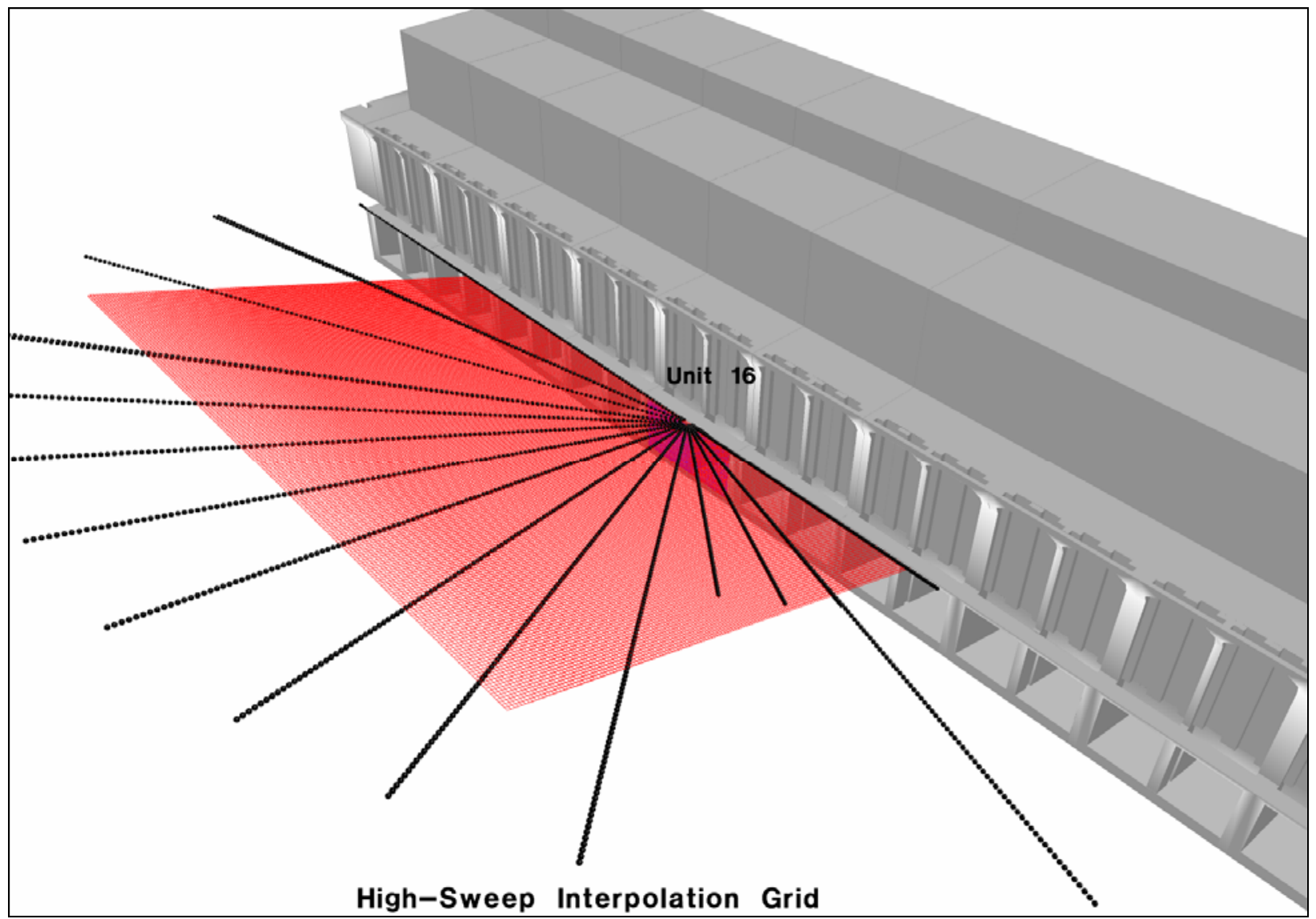

Figure 3.15. Measurement Points (black dots) and the Interpolation Grid Used to Generate Along-Beam Velocity and RMS Velocity Fluctuations Figures 

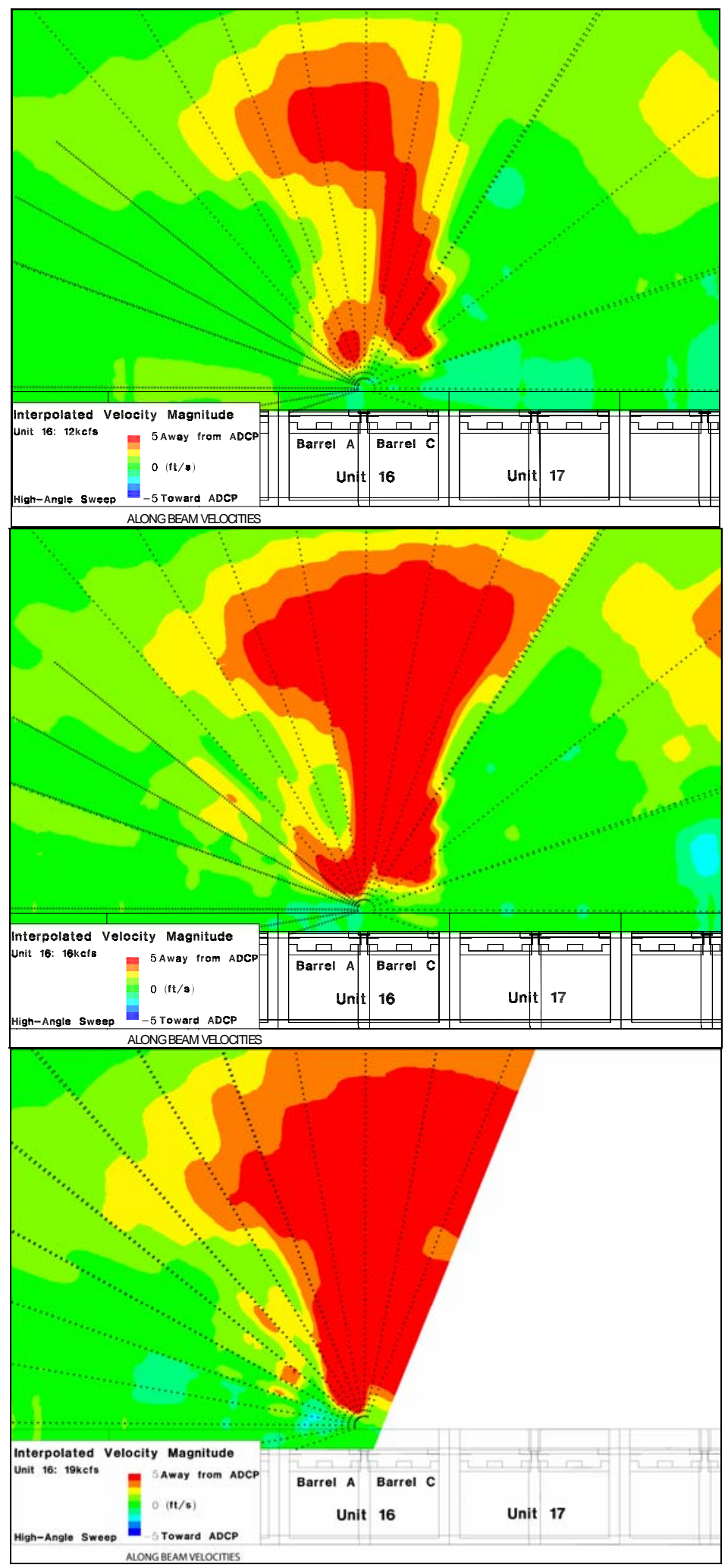

Figure 3.16. Along-Beam Velocity Magnitudes at Low (top), Medium (center), and High Discharge (bottom). Black dots indicate measurement locations. Contours have been blanked in zones where supporting data were not available. 


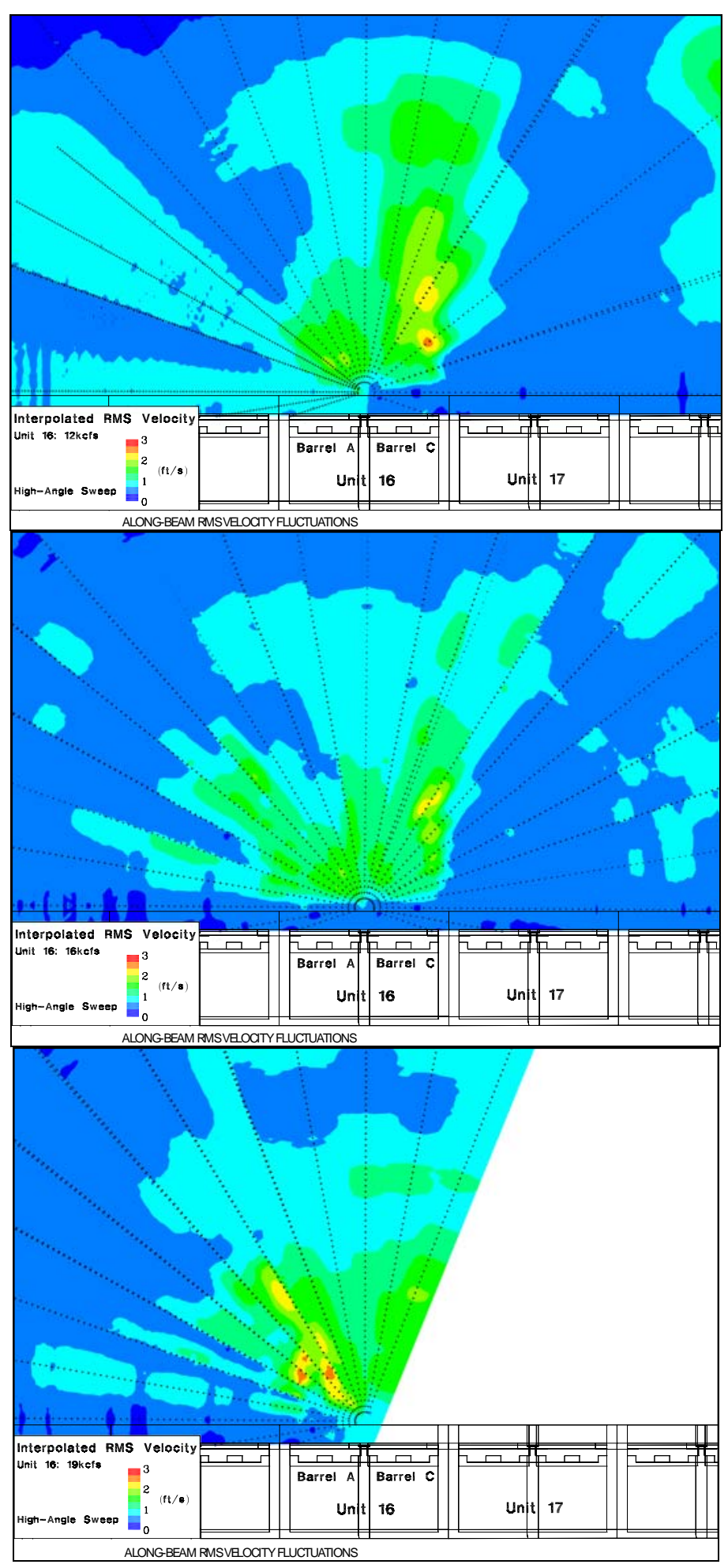

Figure 3.17. Along-Beam RMS Velocity Fluctuations at Low (top), Medium (center), and High Discharge (bottom). Black dots indicate measurement locations. Contours have been blanked in zones where supporting data were not available. 


\subsection{Bathymetry Measurements and Draft Tube Boil Locations}

\subsection{Unit 16 Tailrace Bathymetry}

Bathymetric data were extracted from powerhouse-mounted ADCP data sets. Although not generally used as a fathometer, ADCPs are capable of providing good range-to-target information from the transducer to the bottom along the length of the beam. However, because the beams typically diverge at 20 degrees from the vertical, the distance from the transducer to the bottom is generally not a useful bathymetry measurement unless distance is projected to a true depth and the location is computed taking into account pitch and roll of the ADCP.

During this project, the exact location and orientation of the unit were known at all times, so typical transducer-to-target (either bottom or dam) distances would provide an accurate bathymetric data set. Unfortunately, the best "mode" with which to collect this information would have been the "bottom ping" mode, which is part of normal bottom tracking when collecting discharge measurements. However, the 6-degree ADCP units were custom-designed for mounted deployments, and RD Instruments has not developed bottom tracking capability for these instruments. Therefore, the non-ideal "water ping" mode was used to collect bathymetric data, which results in a decrease of accuracy to approximately one bin size $(0.5 \mathrm{~m})$. Often, the bottom crossed over into two bins, and the bottom could be determined to only the closest $1.0 \mathrm{~m}$. Although not extremely accurate by typical surveying standards, this data set may provide the Portland District, USACE, with some general information regarding bathymetry near Unit 16.

Figure 4.1 displays the collection of ADCP transducer-to-target distances used to generate bathymetry. Both the center $300-\mathrm{kHz}$ and south $600-\mathrm{kHz}$ ADCPs were used. Green lines between the beam intersections with the bottom show the new bathymetric surface generated from these data in outline form. Figures 4.2 and 4.3 display the new bathymetric surface developed by PNNL, which incorporates both ADCP data and fathometrer collected bathymetric data (boat soundings) provided by the Portland District, USACE. Agreement between ADCP measurements and the USACE fathometer data set was quite good in the few locations where the two data sets overlapped.

A scour hole was detected near the draft tube exits between Units 16 and 15 and is clearly visible in Figure 4.3. The extent of this hole appears to be rather limited, however, in terms of distance downstream from the draft tube. To illustrate the extent of the scour hole, several cross sections were extracted. A plan view of location of the cross sections is shown in Figure 4.4, and the corresponding side view is shown in Figure 4.5. The hole is within $40 \mathrm{ft}$ of the draft tube exit and appears to be less than $10 \mathrm{ft}$ below the draft tube invert elevation (minimum elevation was approximately $60 \mathrm{ft}$ ). Extent and depth of this hole should be regarded as preliminary, however, because of the non-ideal sampling mode. 


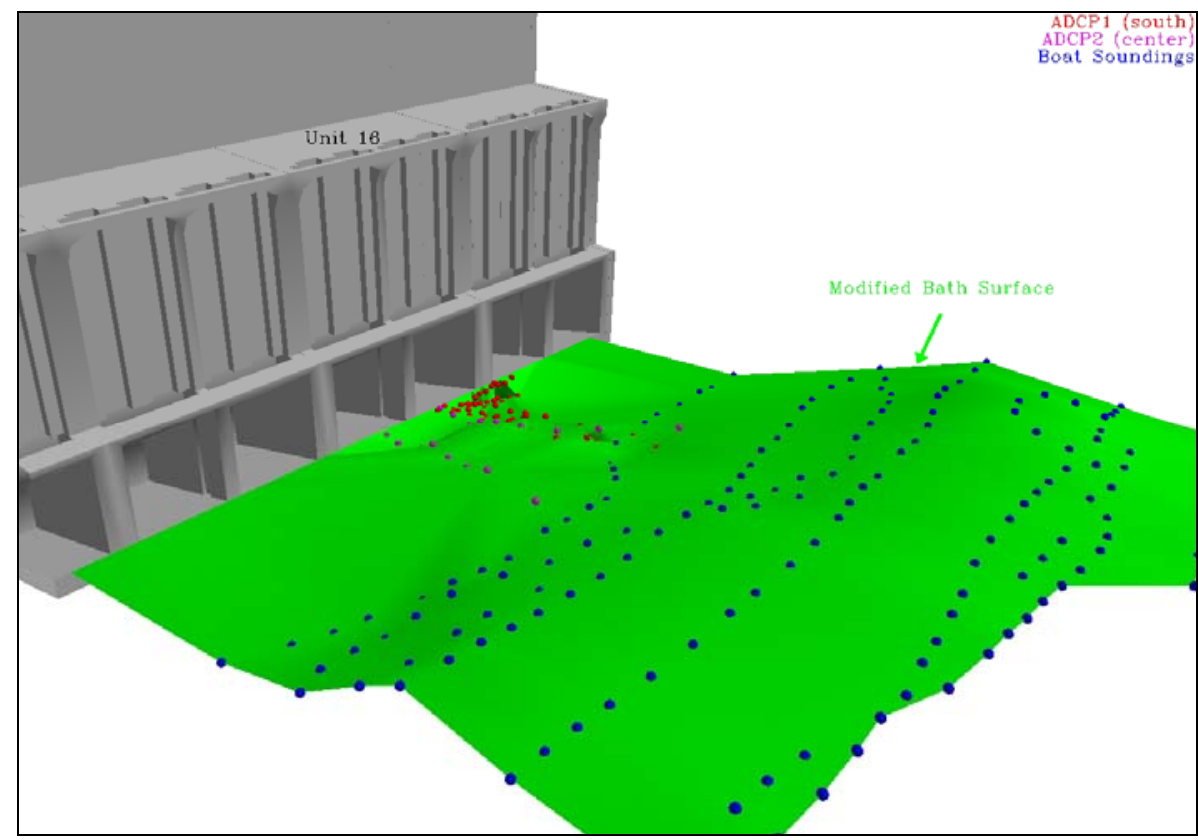

Figure 4.1. Locations of ADCP Bathymetric Measurements (red and pink spheres) versus the Hydrographic Survey Conducted for Portland District, USACE (blue spheres), and Used to Generate the CFD Model Bathymetry (green interpolated surface)

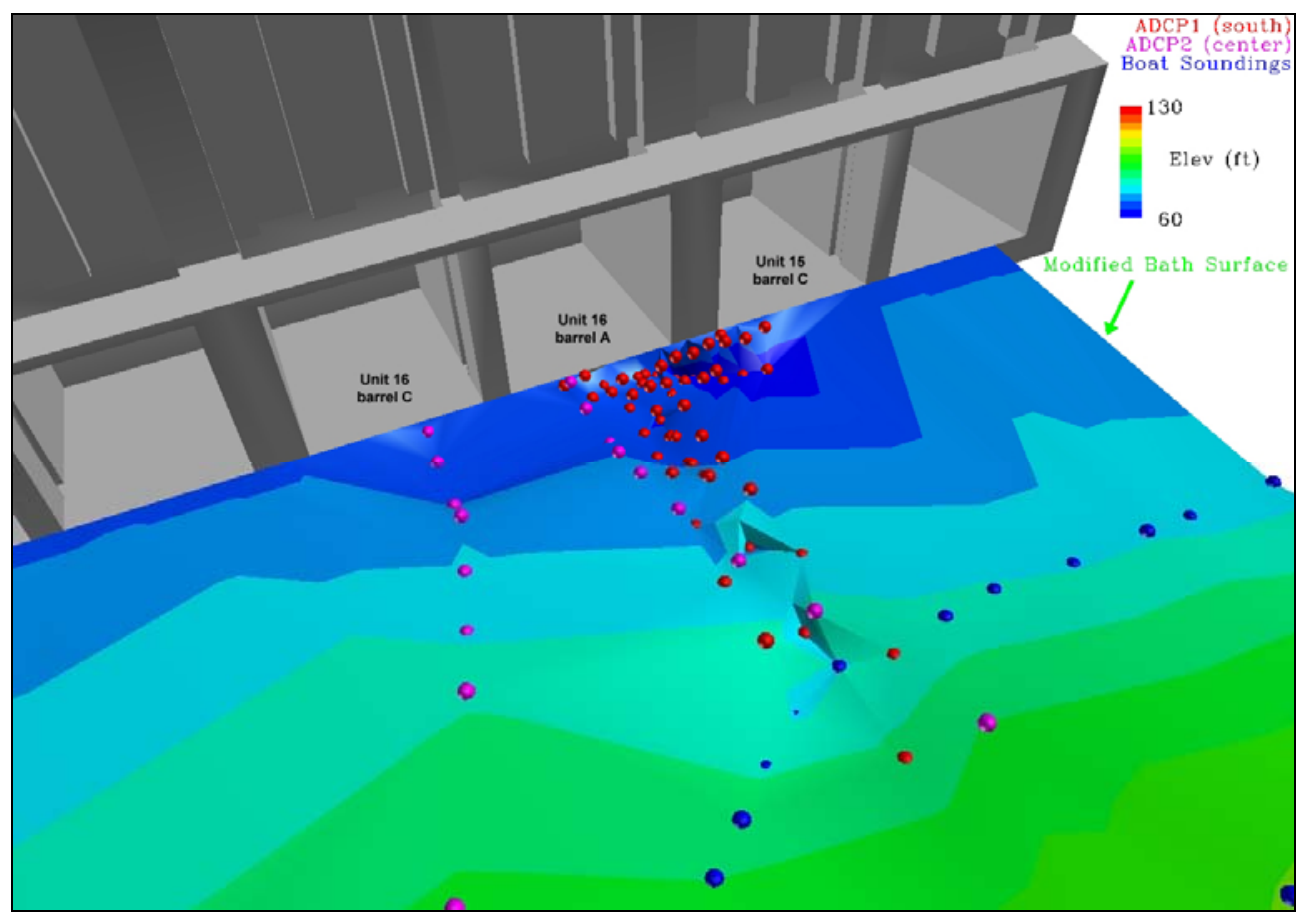

Figure 4.2. Contours of Bathymetry. Note the scour hole observed between Units 15 and 16 . 


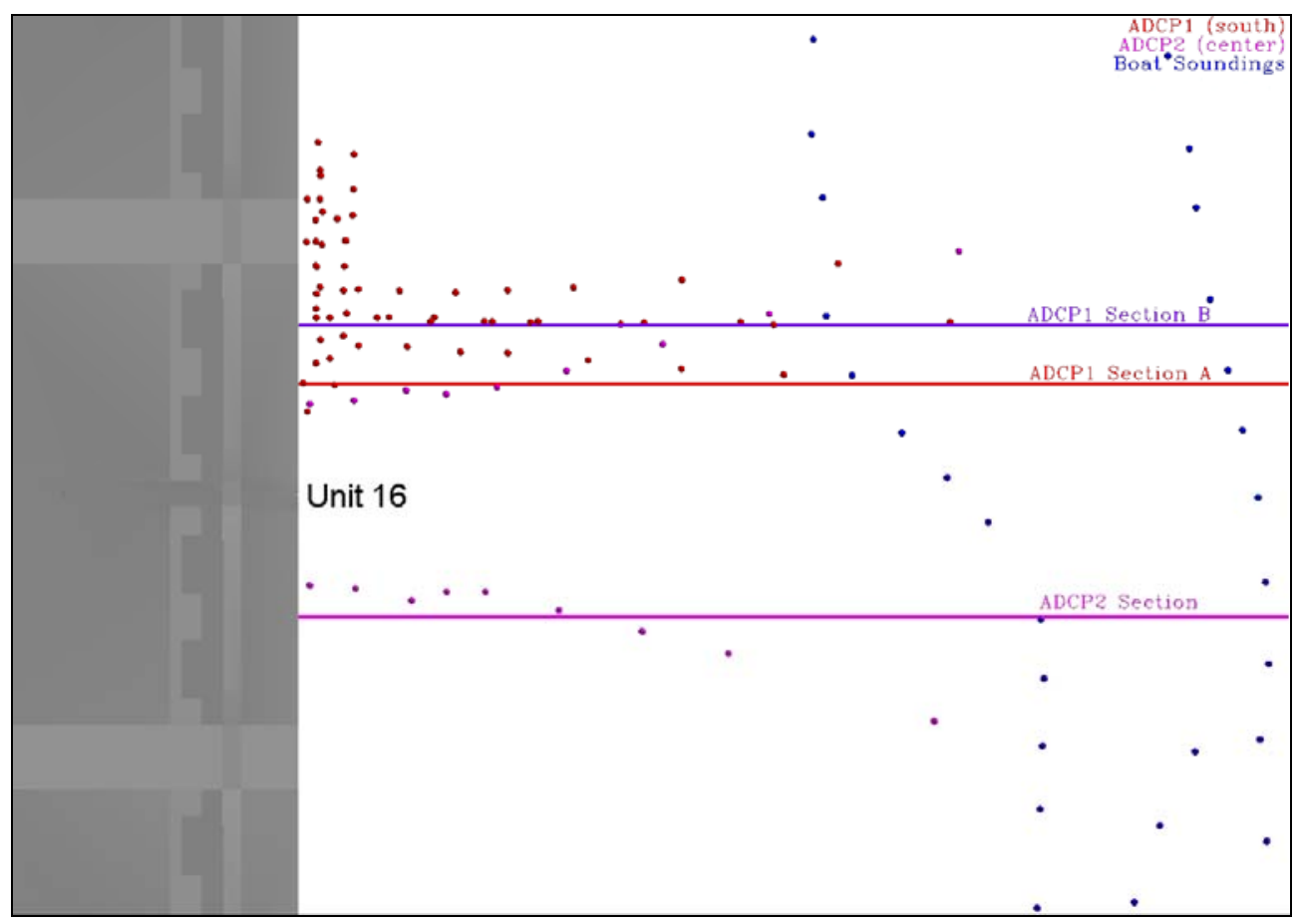

Figure 4.3. Plan View of the Tailrace Downstream of Unit 16 and Showing Cross-Section Lines. Unit 15 is toward the top of the figure.

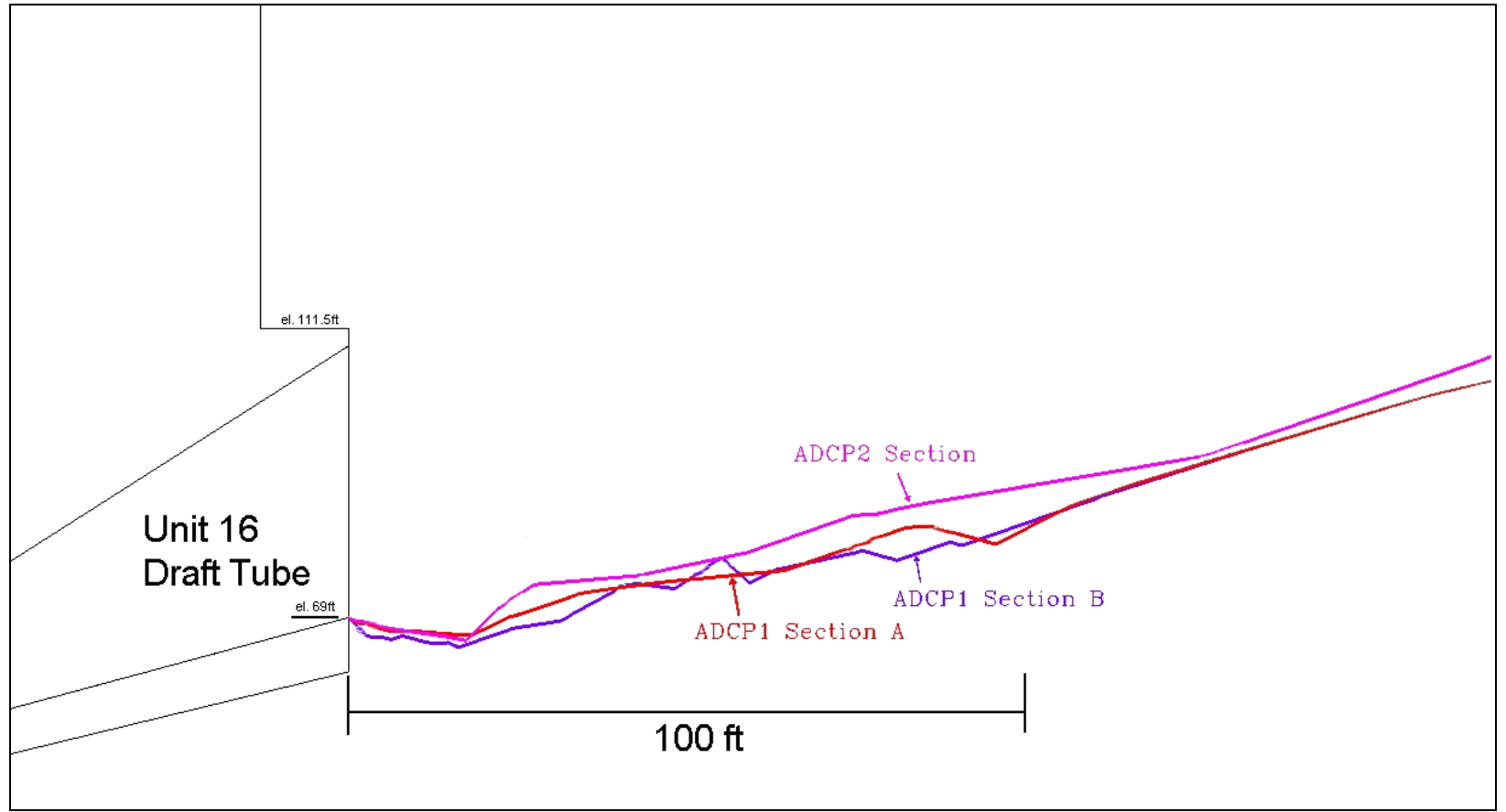

Figure 4.4. Contours of Bathymetry Along the Cross-Section Lines Shown in Figure 4.3. Note the scour hole observed between Units 15 and 16. 


\subsection{Draft Tube Boils}

Surface boils are clearly visible downstream of the operating John Day Dam turbine units. These boils are transient, and violent eruptions were noted to occur at a regular frequency. The locations of these surface phenomena were of interest to the Portland District, USACE, so PNNL researchers documented their locations during the study.

These surface boils are shown in Figure 4.6. Distances from the bridge deck to the surface boils were measured using a hand-held laser range finder. Distances are only approximate but generally ranged between 50 and $75 \mathrm{ft}$.

Farther downstream of the initial surface boils, visible locations of upwelling water were observed. The locations of these upwelling zones were recorded during the mobile reconnaissance portion of this project. These GPS distances were then projected and computed as distances from the bridge deck. The resulting schematic is shown in Figure 4.7.

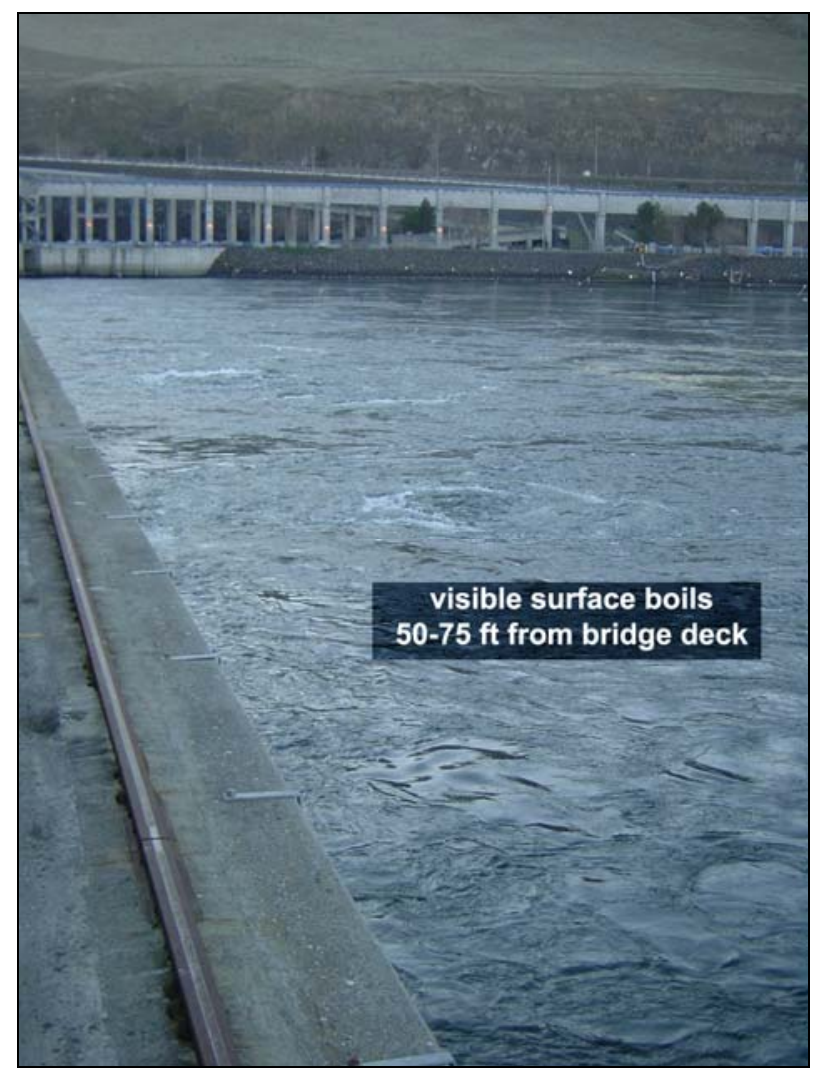

Figure 4.5. Surface Boils Downstream of the Draft Tube Exit 


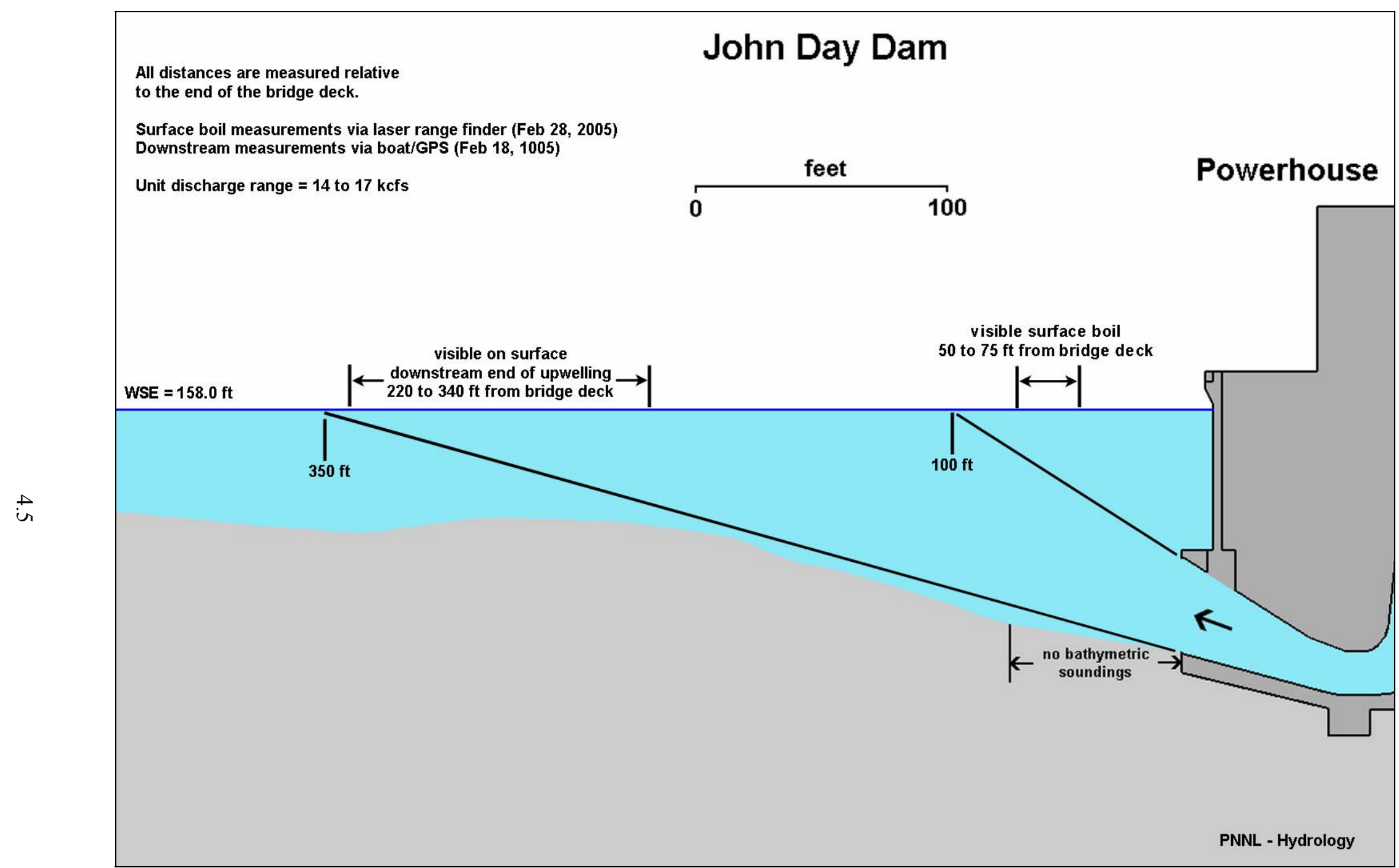

Figure 4.6. Tailrace Schematic Showing Approximate Locations of Visible Surface Boils and Upwelling Zone 


\subsection{Conclusions and Recommendations}

This report presents results of a study designed to collect prototype water velocity data sets that can be used to validate numerical and physical models of the John Day Dam tailrace. This work was funded by the Hydraulic Design Section, Portland District, U.S. Army Corps of Engineers (USACE) and was conducted by a team of researchers from the Pacific Northwest National Laboratory (PNNL).

\subsection{Conclusions}

Collection of 3D water velocities using acoustic Doppler current profilers (ADCPs) in the far-field tailrace zone is fairly routine, and the approach used during this project has been well documented in the technical literature. We conclude from this mobile survey of conditions that the tailrace zone downstream of John Day Dam is hydraulically complex. A large gyre was noted between skeleton bays 17 through 20 and the nonspilling portion of the spillway. Downstream of the spillway, the spillway flow is constrained against the navigation lock guide wall, and large velocities were noted in this region. At a distance of $9,000 \mathrm{ft}$ downstream from the dam, flows had equalized laterally and were generally uniform over the cross section.

Through previous studies at PNNL, the authors have shown that calibration and validation data sets for CFD and physical models can be obtained through the use of 1D (along-beam) velocity measurements collected by an ADCP. In addition, the feasibility of converting the $1 \mathrm{D}$ velocity measurements into meaningful 3D velocity vectors was investigated by PNNL. We conclude from this project that it is technically feasible to measure both 1D and 3D water velocities directly downstream of an operating turbine unit using narrow beam-spread (6-degree) ADCPs. Data products generated during this project include a measurement of turbine discharge per draft tube barrel (i.e., the flow split), directional changes and the general decay of velocity as flow exits the draft tube and enters the tailrace, and an index analogous to $1 \mathrm{D}$ turbulent fluctuations (i.e., RMS velocity fluctuations).

\subsection{Recommendations}

As a result of this research, specific recommendations are outlined below. These actions are suggested for future studies that may involve similar measurements:

1. On/off studies of adjacent turbine units are recommended to better understand how crossflow affects turbine exit conditions. Unit 15 was down for maintenance during the project's sampling period. Rescheduling of the research project until maintenance on Unit 15 was completed was not possible because spillway operations had to occur outside of the fish passage season.

2. Improve turbine blocking so that settings do not change during the ADCP measurements. Even slight changes in turbine settings (e.g., wicket gate opening or blade angle) can affect the flow through the turbine unit. During this study, turbine settings were monitoring periodically by reading the settings directly off the unit. Values were found to change slightly during the periods of prescribed uniform discharge. For example, on February 23, the blade changed on Unit 16 from 13.2 (9:35 a.m./GDACS Q $=19.5 \mathrm{kcfs})$ to 12.5 (4:15 p.m./GDACS Q $=19.1 \mathrm{kcfs})$ and on 
February 24, the blade angle changed between 8.5 (08:55 a.m./GDACS Q $=16.3 \mathrm{kcfs})$ and 8.7 (5:45 p.m./GDACS Q $=16.2 \mathrm{kcfs})$ during the measurement period.

3. Powerhouse ADCPs should be deployed inline with dividing wall/pier centerlines. Although the field of view of the ADCPs may be decreased (i.e., it may be unable to peer as far into the draft tube), hydraulic forces on the ADCPs would be decreased if dividing walls/piers are used to shield the instrument. Turbulent forces encountered by the ADCPs were greater than expected on the left and right 6-degree ADCPs (see Figure 2.6), especially during times when discharge through Unit 16 was changed. The center ADCP was more protected and generally experienced less direct hydraulic forcing, which we hypothesize is due to protection offered by the dividing wall.

4. Continued the use of narrow beam-spread (6-degree) ADCP units in the future because of the added value of $3 \mathrm{D}$ velocity vector data. Before this study was conducted, the meaningfulness of resolved 3D vectors from the $6^{\circ}$ ADCPs was doubted because of flow field heterogeneity and the distance between sample volumes of the four ADCP beams. The homogeneity of the flow was investigated by developing a homogeneity index. Through use of this index and examination of the data to empirically choose a cutoff value, we conclude that in many regions it is appropriate and meaningful to compute 3D velocity vectors and therefore recommend further use of these narrow beam-spread ADCPs.

5. Collaborate with RDI to develop custom ADCPs with an increased sampling rate and the ability for beam disablement via direct commands. For this data collection, the sampling rate was at the maximum capable by the ADCP-1.33 Hz, or one profile collected every $0.75 \mathrm{~s}$. Because sound travels at a speed of approximately $1500 \mathrm{~m} / \mathrm{s}$ and the range of data collection is approximately $100 \mathrm{~m}$, a sample theoretically could be collected every $0.13 \mathrm{~s}$ (time to travel out and return). A seven-fold increase in sampling speed could therefore be realized if processing time between pings were reduced. In addition, previous ADCP data collections in confined spaces have shown that acoustic energy from one ADCP beam that reflects off a concrete structure can affect the other three beams enough to render the profile of data meaningless. For this reason, two of the four beams on the center powerhouse ADCP (20-degree) were disabled before the unit was deployed. It would be convenient if disabling of beams were possible through direct commands and did not require physically unplugging the transducer from the ADCP receiver board, as this action cannot be reversed once the unit is deployed. 


\subsection{References}

Brumley BH, KL Deines, RG Cabrera, and EA Terray. May 1993. "Broadband Acoustic Doppler Current Profiler." US Patent 5,208,785.

Davidson RA. 2004. Lower Granite Project Draft Tube Study. U.S. Army Corps of Engineers, Engineer Research and Development Center, Vicksburg, Mississippi.

Gordon RL. 1989. "Acoustic Measurement of River Discharge.” Journal of Hydraulic EngineeringASCE 115(7):925-936.

Meriam JL and LG Kraige. 1986. Engineering Mechanics: Statics. 2nd ed. John Wiley \& Sons, Inc., New York.

Morlock SE. 1996. Evaluation of Acoustic Doppler Profiler Measurements of River Discharge. WaterResources Investigations Report 95-4218, U.S. Geological Survey, Indianapolis, Indiana.

Muste M, K Yu, T Pratt, and D Abraham. 2004b. "Practical aspects of ADCP data use for quantification of mean river flow characteristics; Part II: fixed-vessel measurements." Flow Measurement and Instrumentation 15(1):17-28.

Muste M, K Yu, and M Spasojevic. 2004a. "Practical Aspects of ADCP data use for quantification of mean river flow characteristics; Part I: moving-vessel measurement." Flow Measurement and Instrumentation 15(1):1-16.

Schott F. 1987. "Medium-range vertical acoustic Doppler current profiling from submerged buoys." Deep Sea Research Part A - Oceanographic Research 33(10):1279-1292.

Simpson MR. 2001. Discharge Measurements Using a Broad-Band Acoustic Doppler Current Profiler. Open File Report 01-1, U.S. Geological Survey, Sacramento, California.

RDI. 1996. "Acoustic Doppler Current Profiler: Principles of Operation.” Teledyne RD Instruments, Inc., San Diego, California.

RDI. 1998a. "ADCP Coordinate Transformation: Formulas and Calculations." Teledyne RD Instruments, Inc., San Diego, California.

RDI. 1998b. “Workhouse Technical Manual.” Teledyne RD Instruments, Inc., San Diego, California.

USACE. 2005. “The Dalles/John Day/Willow Creek - General Information.” U.S. Army Corps of Engineers, Portland District, Portland, Oregon. Available at https://www.nwp.usace.army.mil/op/d/johnday.asp (January 24, 2006). 
Appendix A

Boat-Mounted ADCP Measurements: Graphical Results 


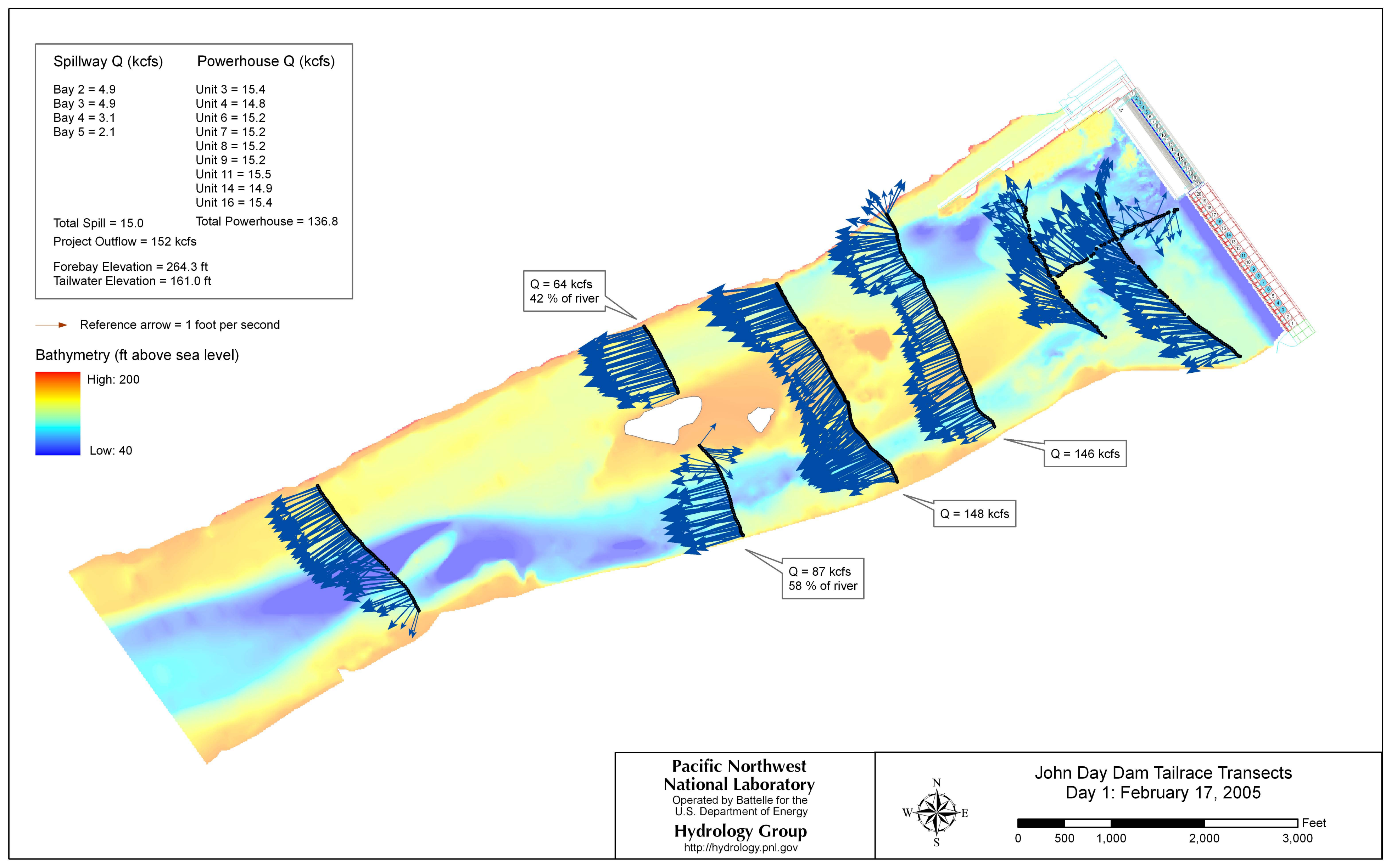




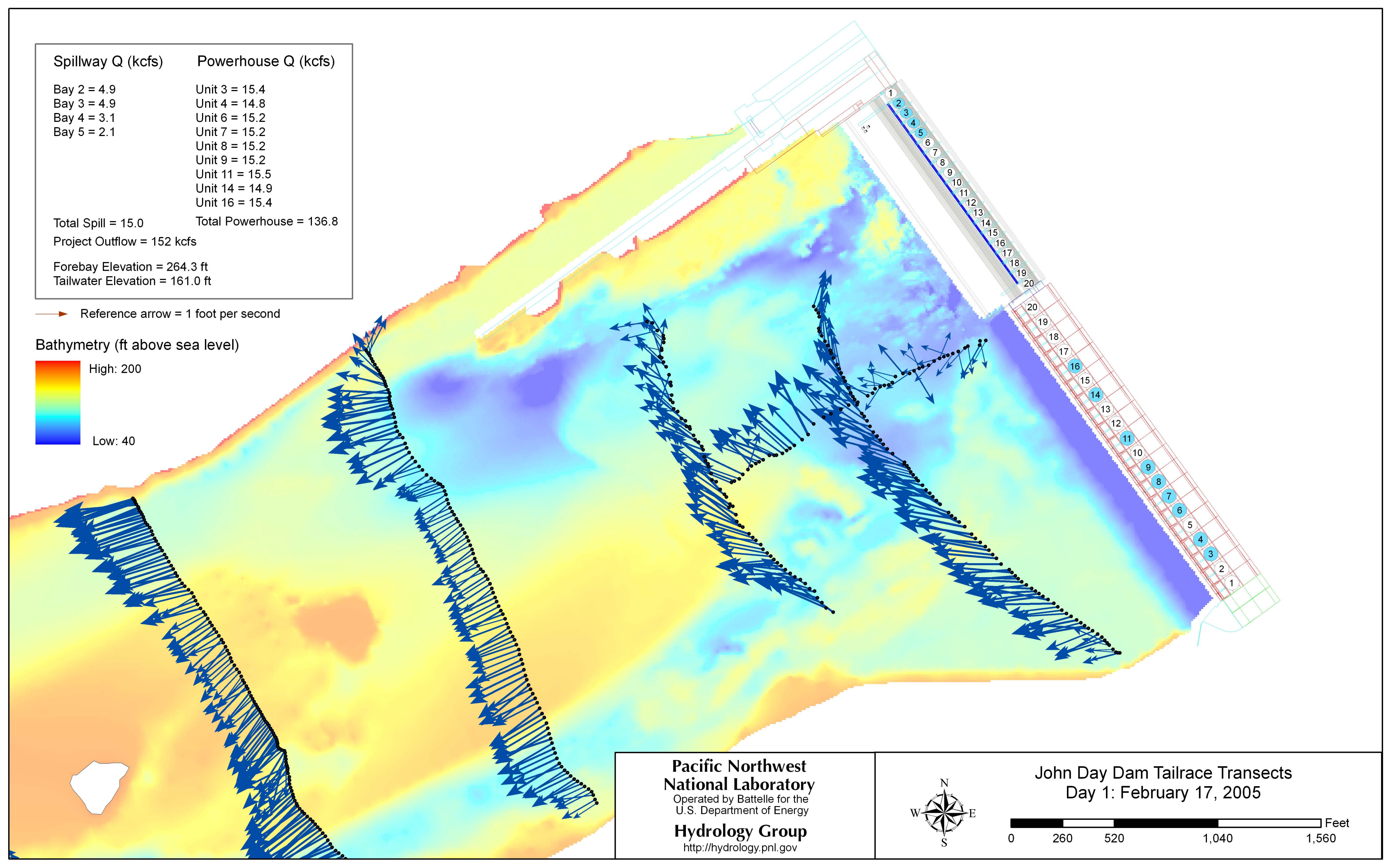




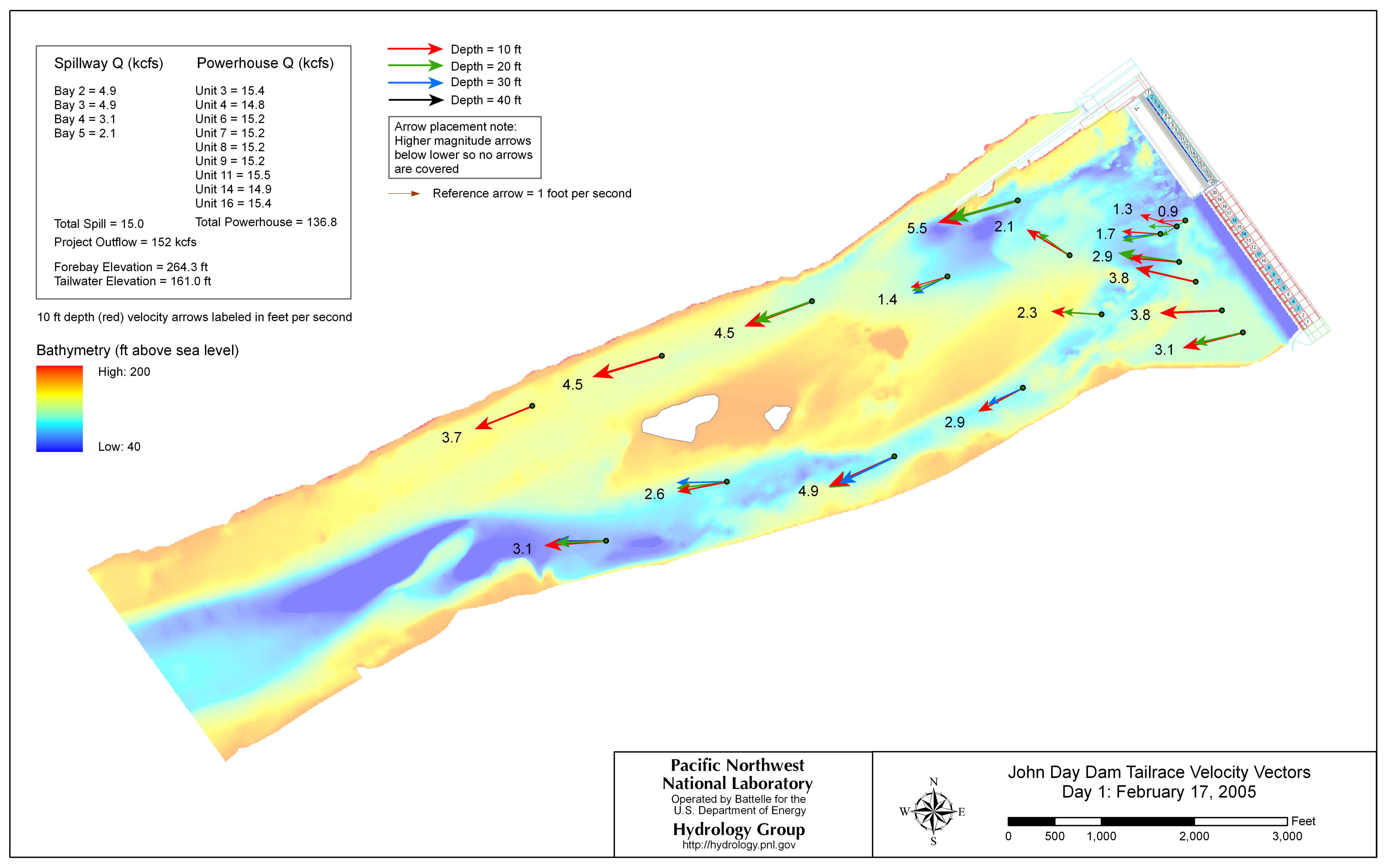




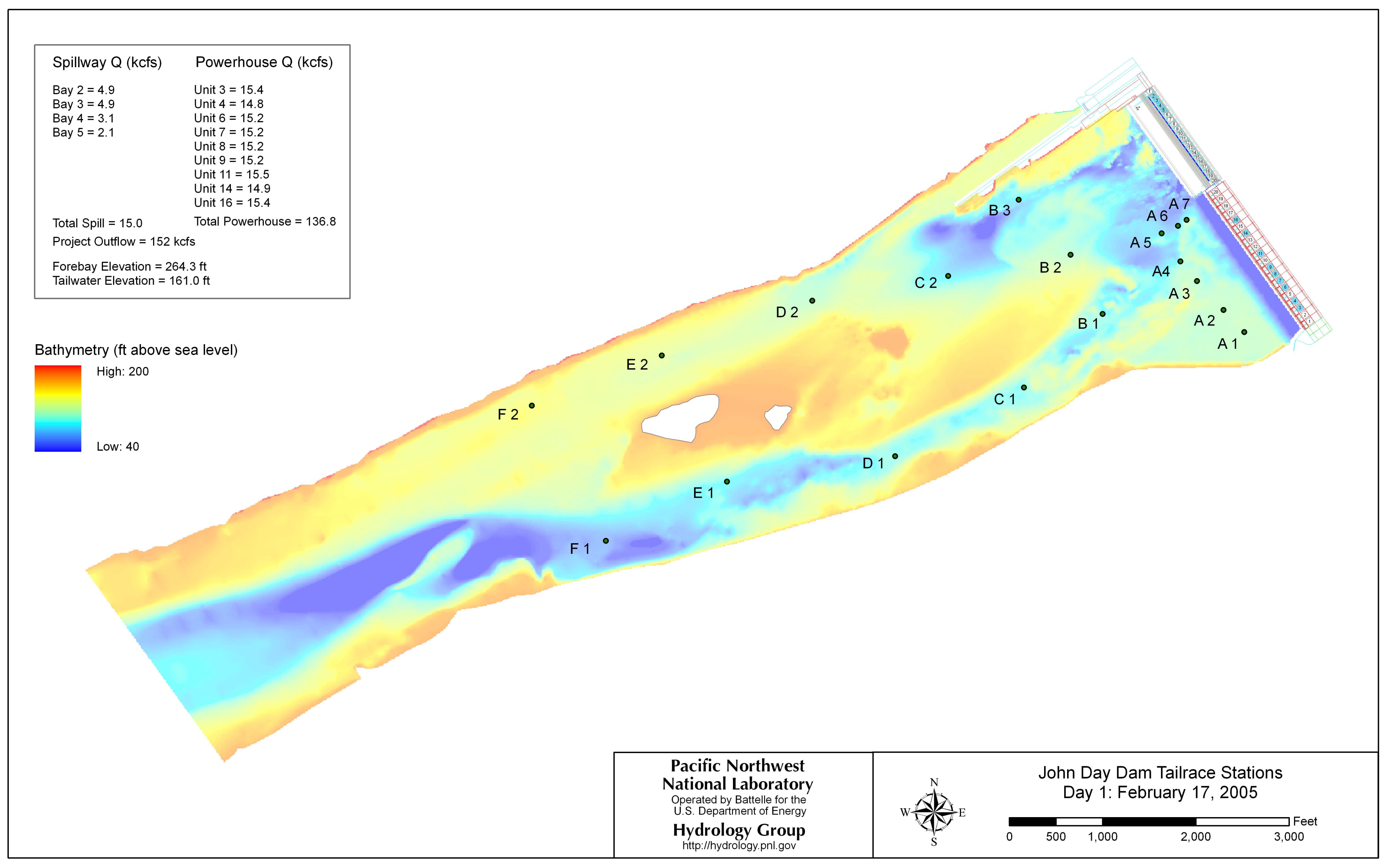




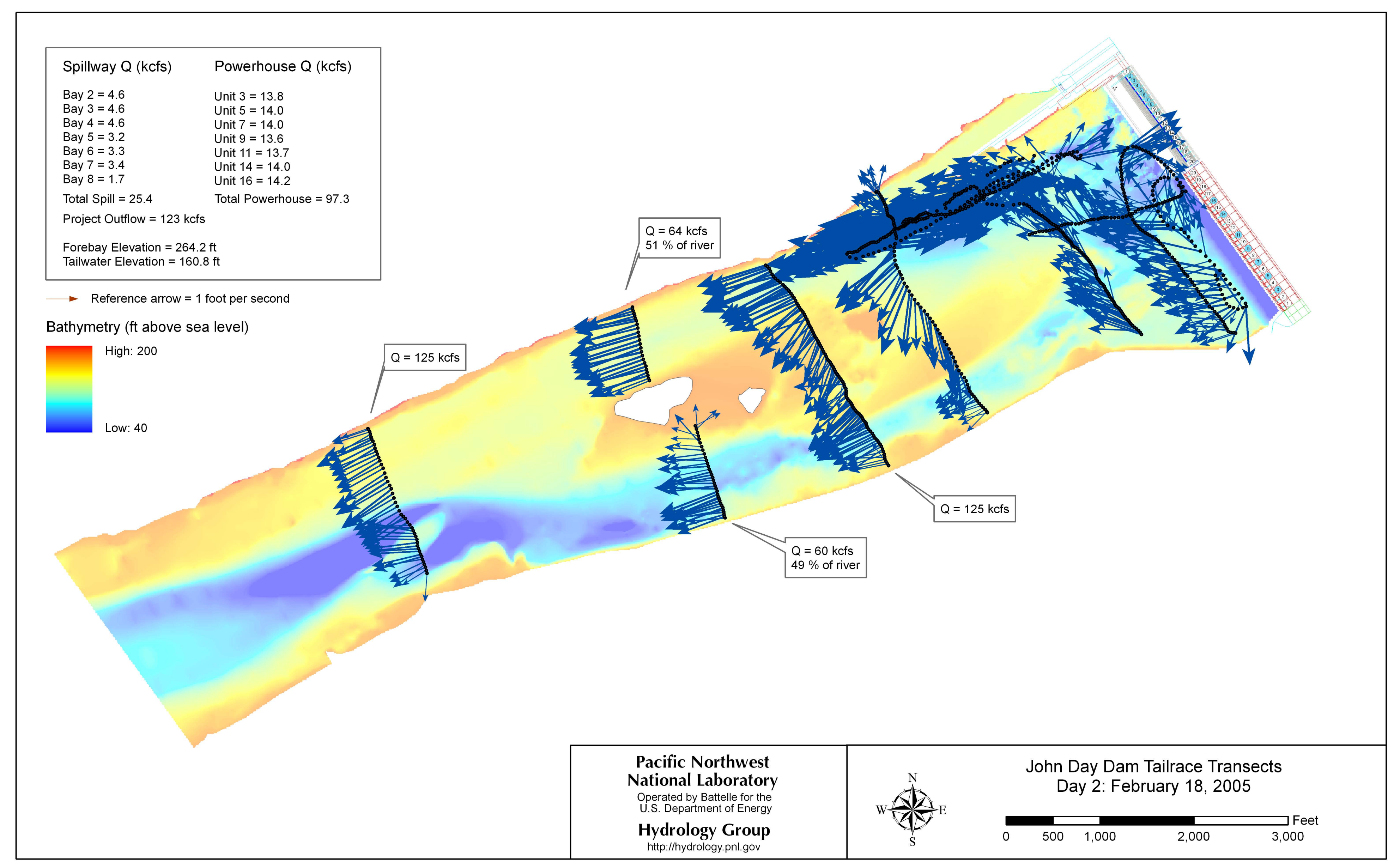




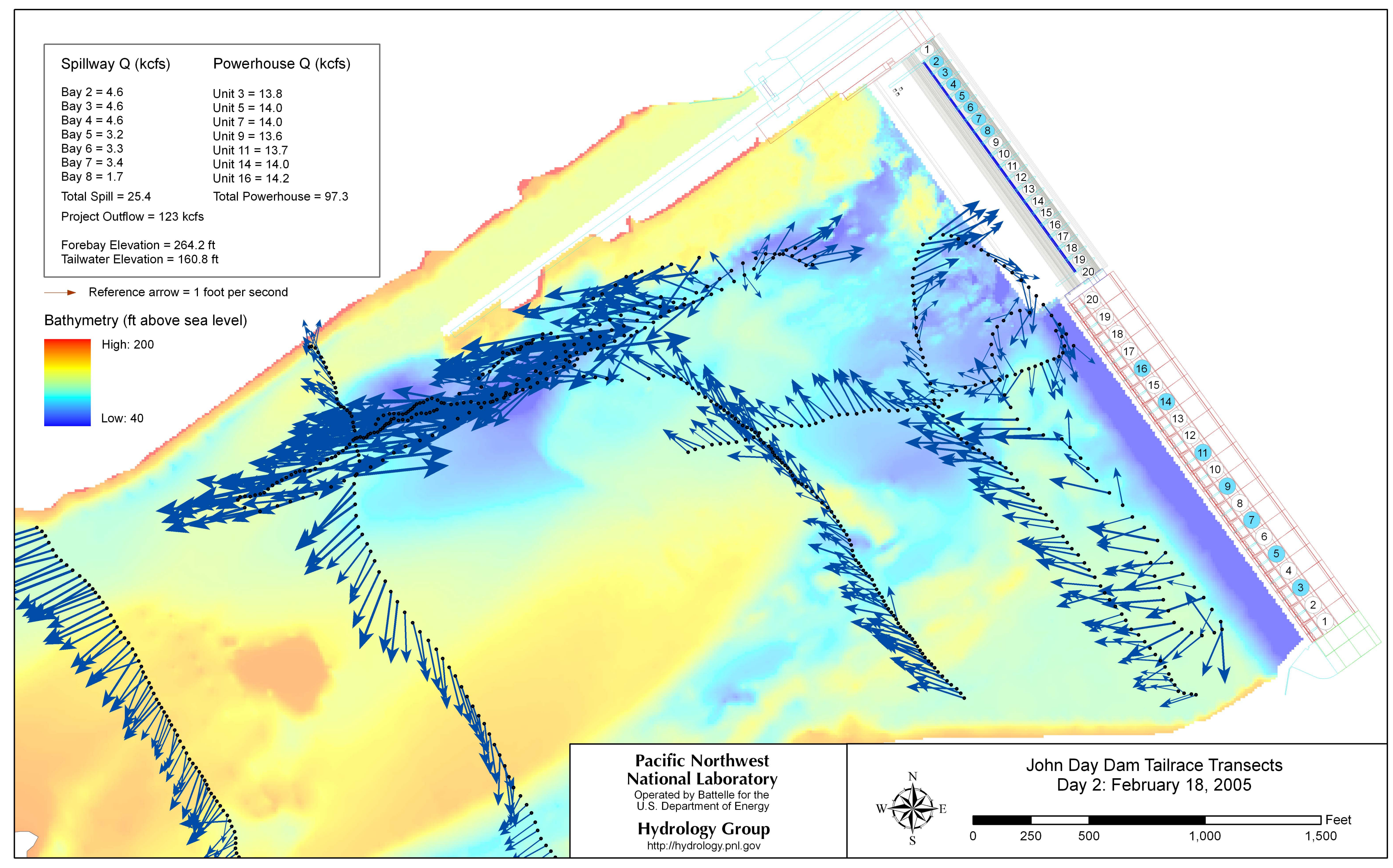




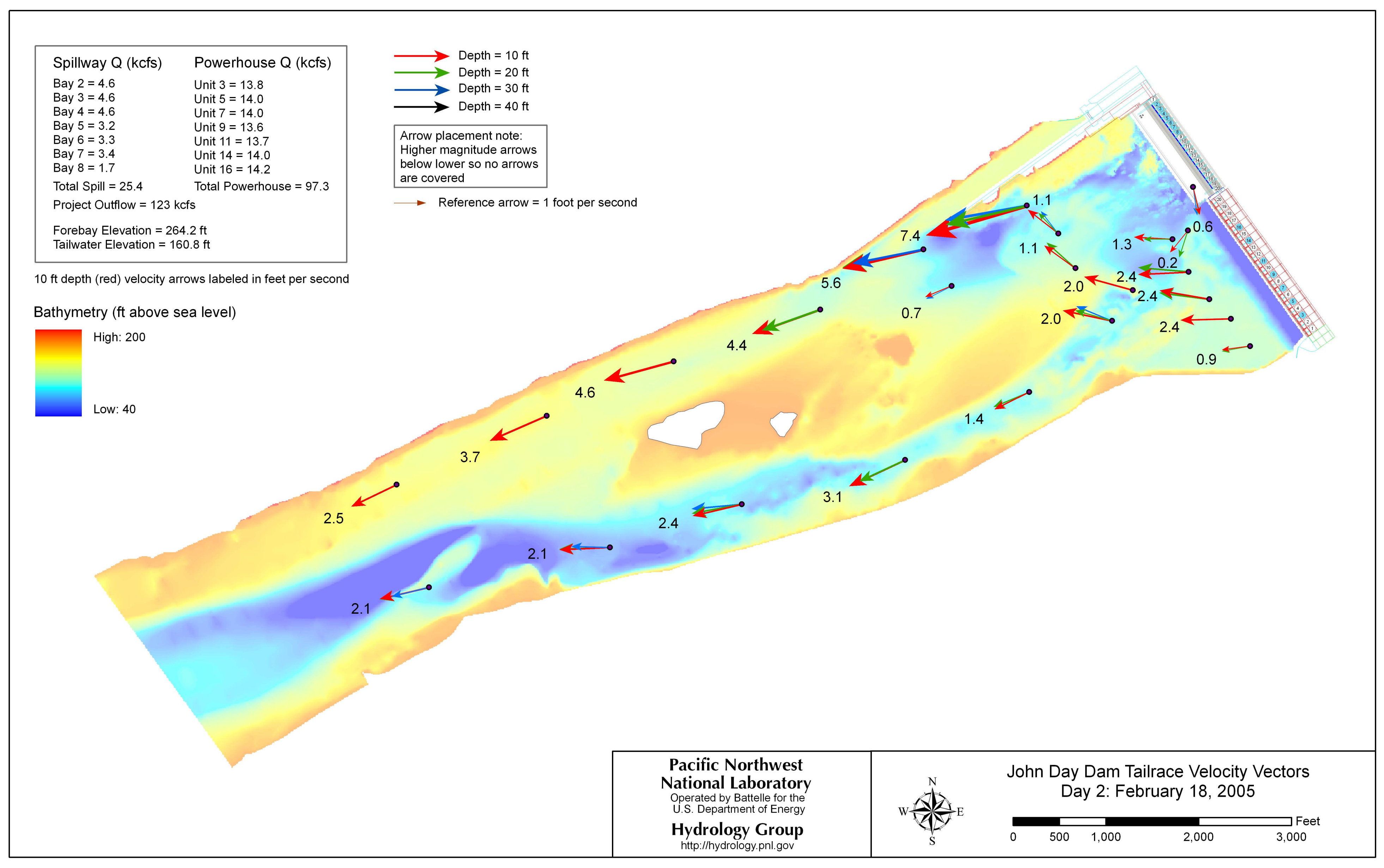




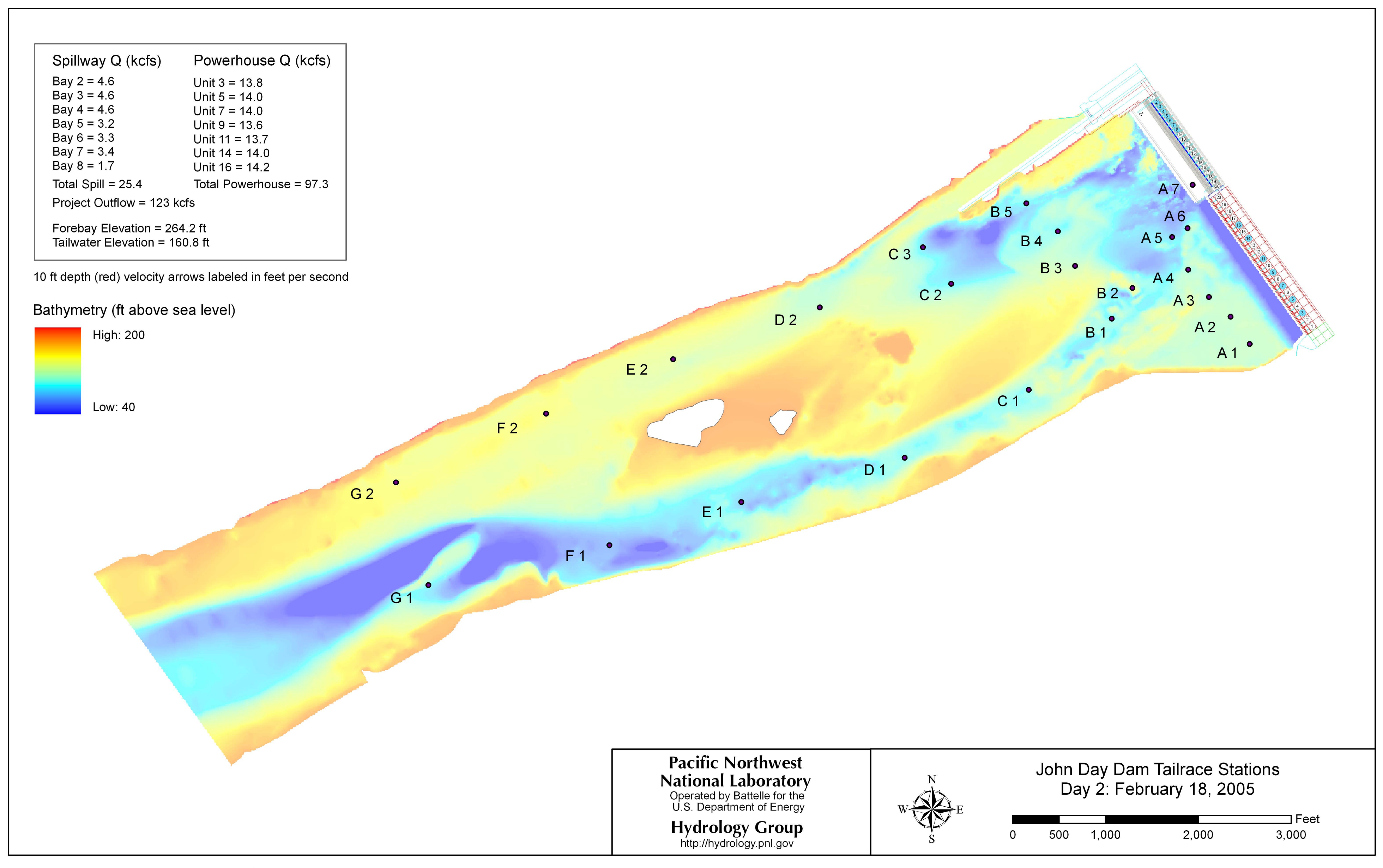


Appendix B

Graphical Views of Measured Three-Dimensional Water Velocity Vectors 


\section{Appendix B}

\section{Graphical Views of Measured Three-Dimensional Water Velocity Vectors}

This appendix presents three views of each 3D velocity measurement observed using the south 6degree ADCP. Presented data were filtered by the homogeneity index value (see Section 2.3.4). An index value of $0.7 \mathrm{ft} / \mathrm{s}$ was used as the maximum cutoff value.

A compact disk (CD) has also been assembled to accompany this report. This CD contains all raw data files and processed data collected by this ADCP. In addition, this CD also includes a standalone document that defines the coordinate system developed to describe the rotation angles of the powerhouse ADCP beams.

In this appendix, each 3D velocity measurement is shown from three viewing angles. Going from the top to the bottom of each page, these views are: front view, plan view, and side view. The figures have been organized by collection time (file name), which can be viewed in the bottom left of each figure. Also in the figure caption are: Unit 16 discharge, length of measurement (minutes) and number of readings are shown. The file-naming convention is as follows: ADCP1_MDD_HHMM, where M is the month, DD is the date, $\mathrm{HH}$ is the hour, and MM is the minute. Therefore, the file ADCP1_217_1038 is a file collected by south ADCP1 on February 17, 2005 at 10:38 a.m.

Each velocity vector has been colored by velocity magnitude. In addition, a purple sphere has been placed in the figure where the ADCP head was located. 

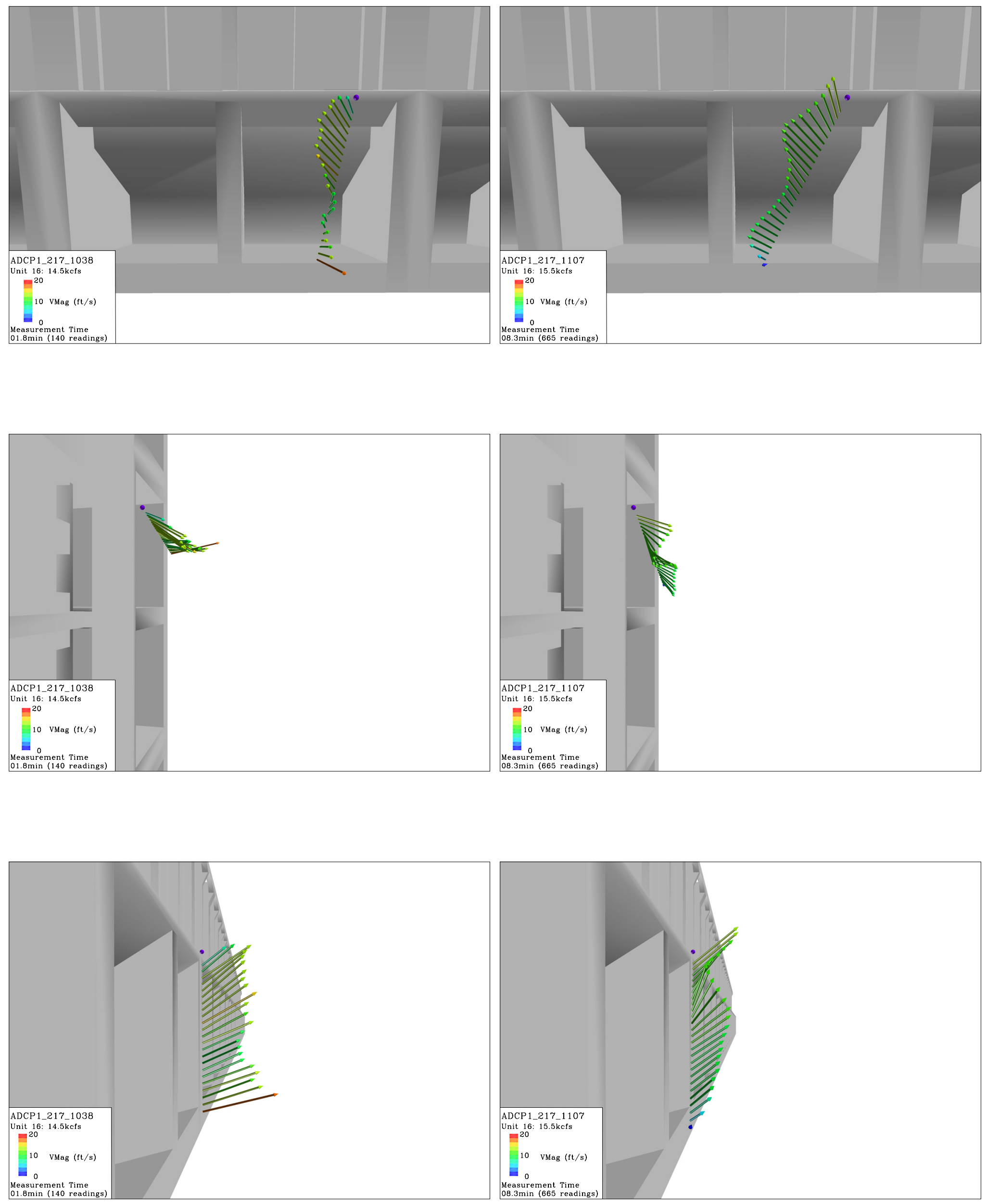

B. 2 

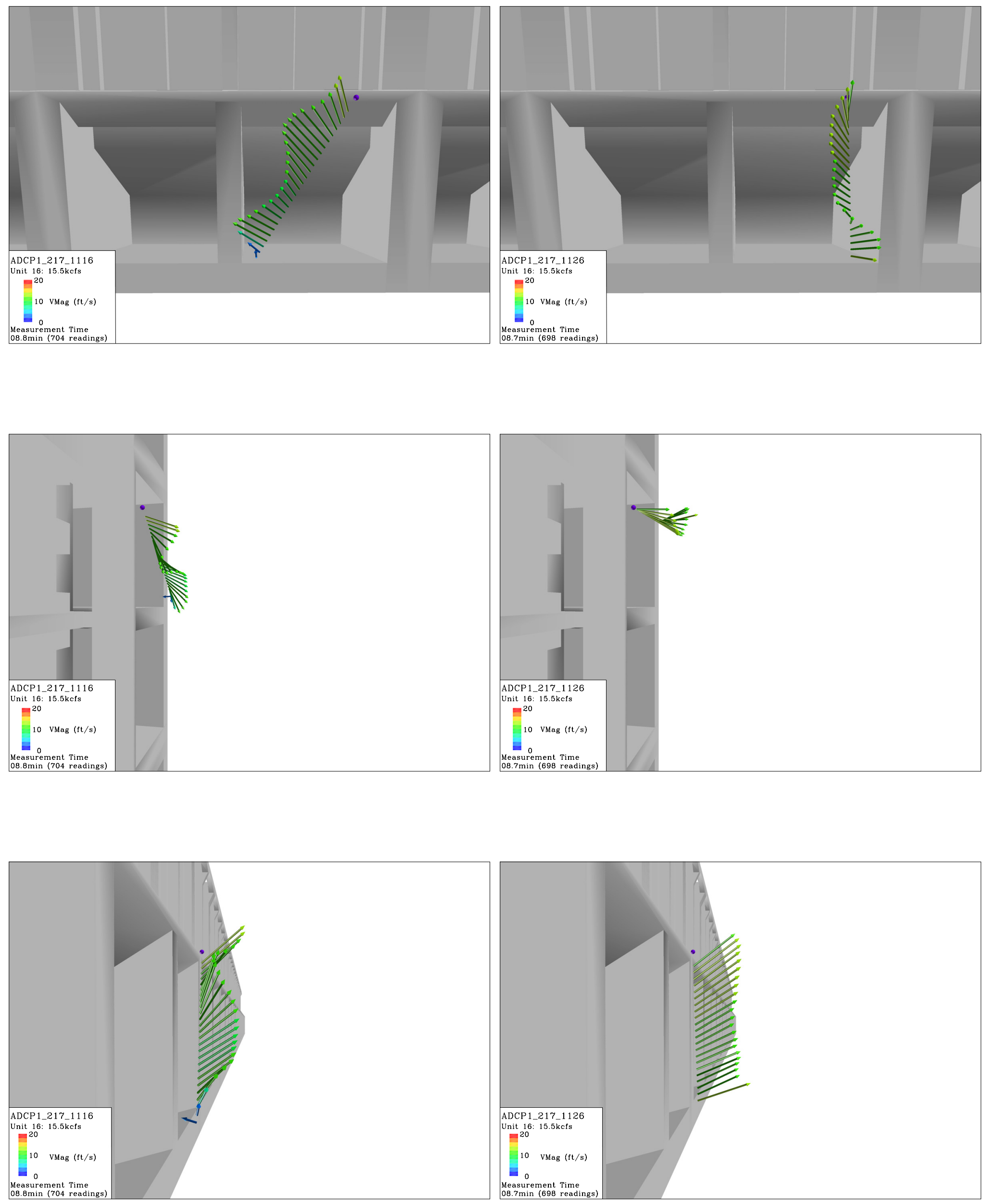

B. 3 

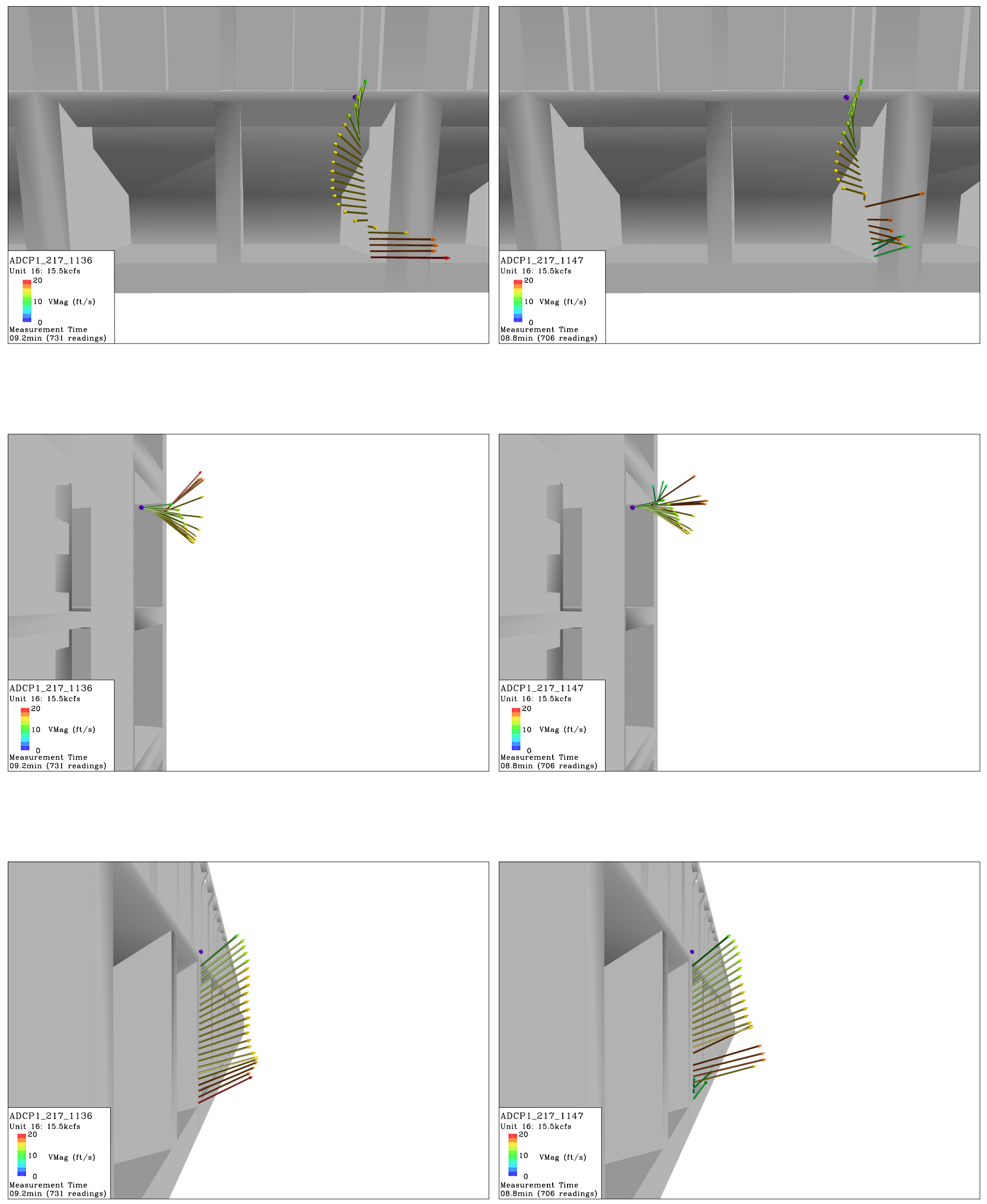

B. 4 

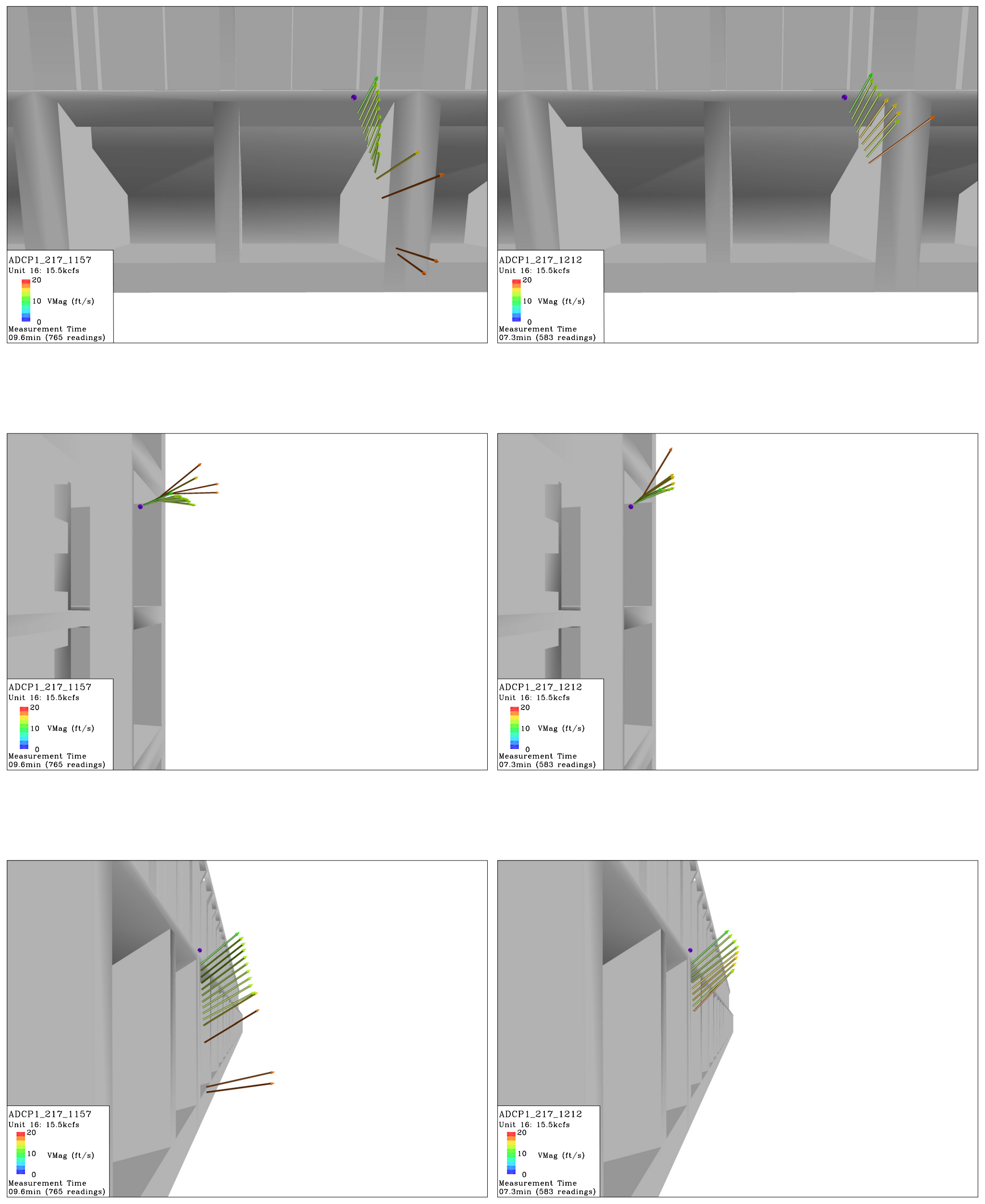

B. 5 

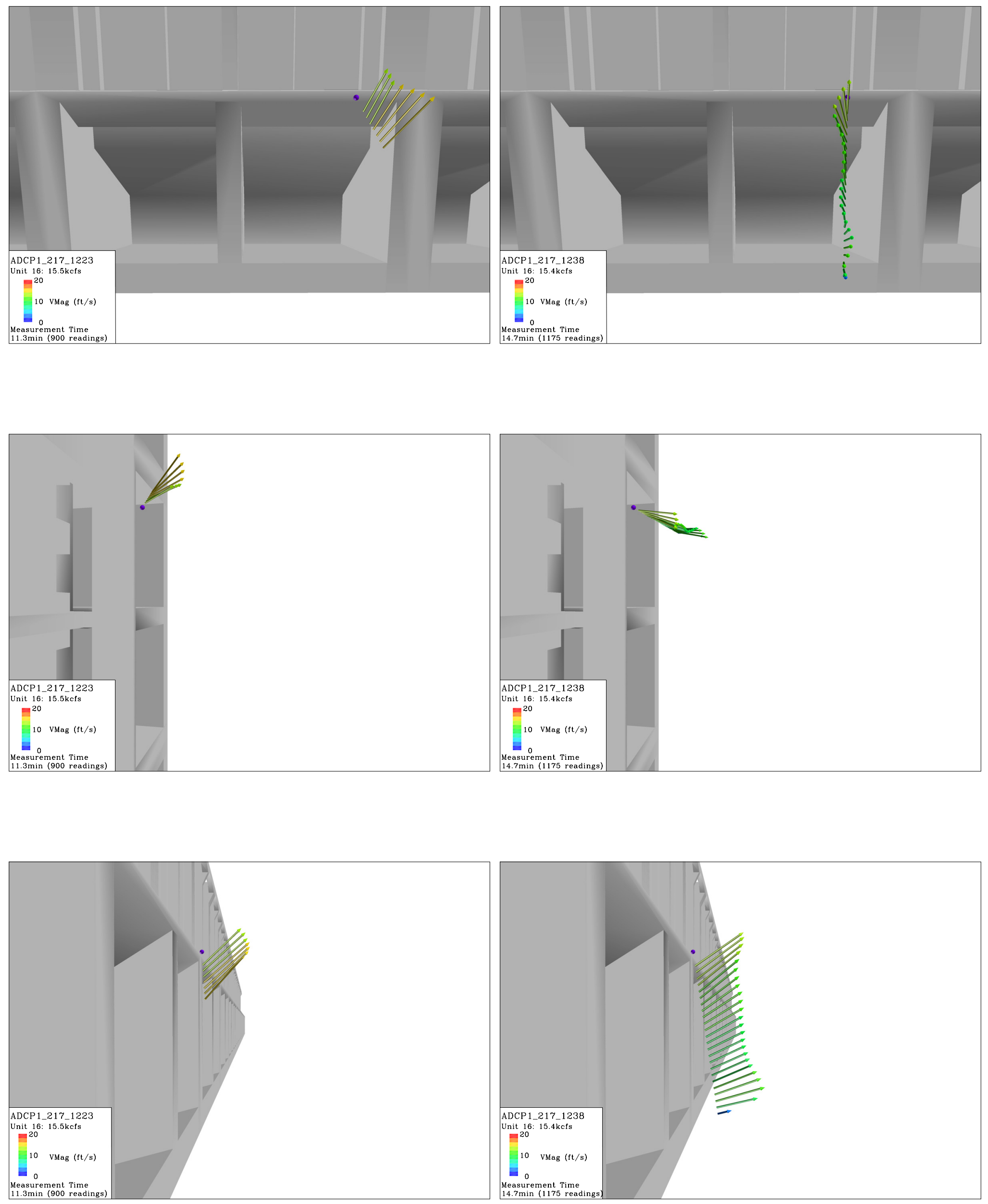

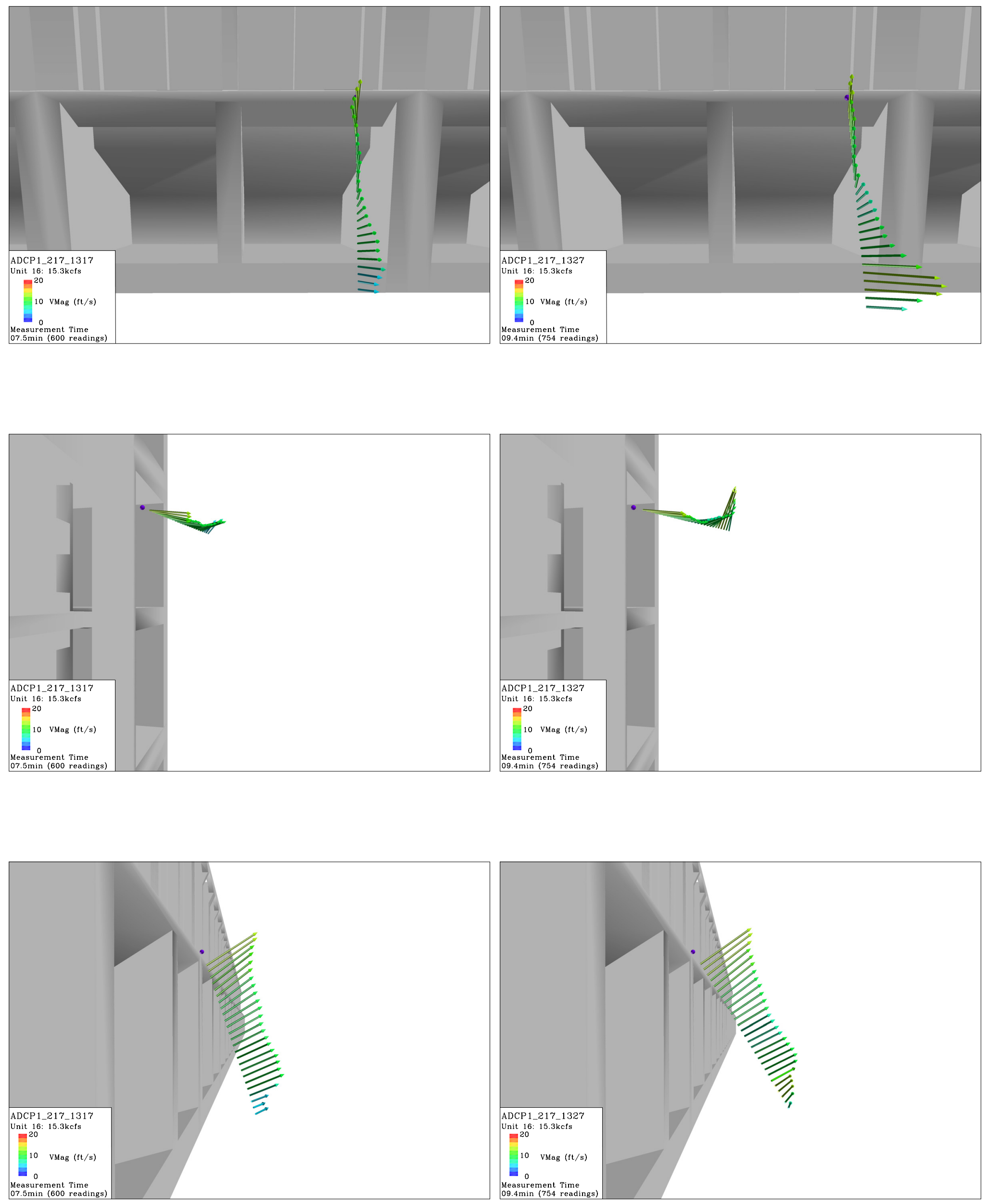

B. 7 

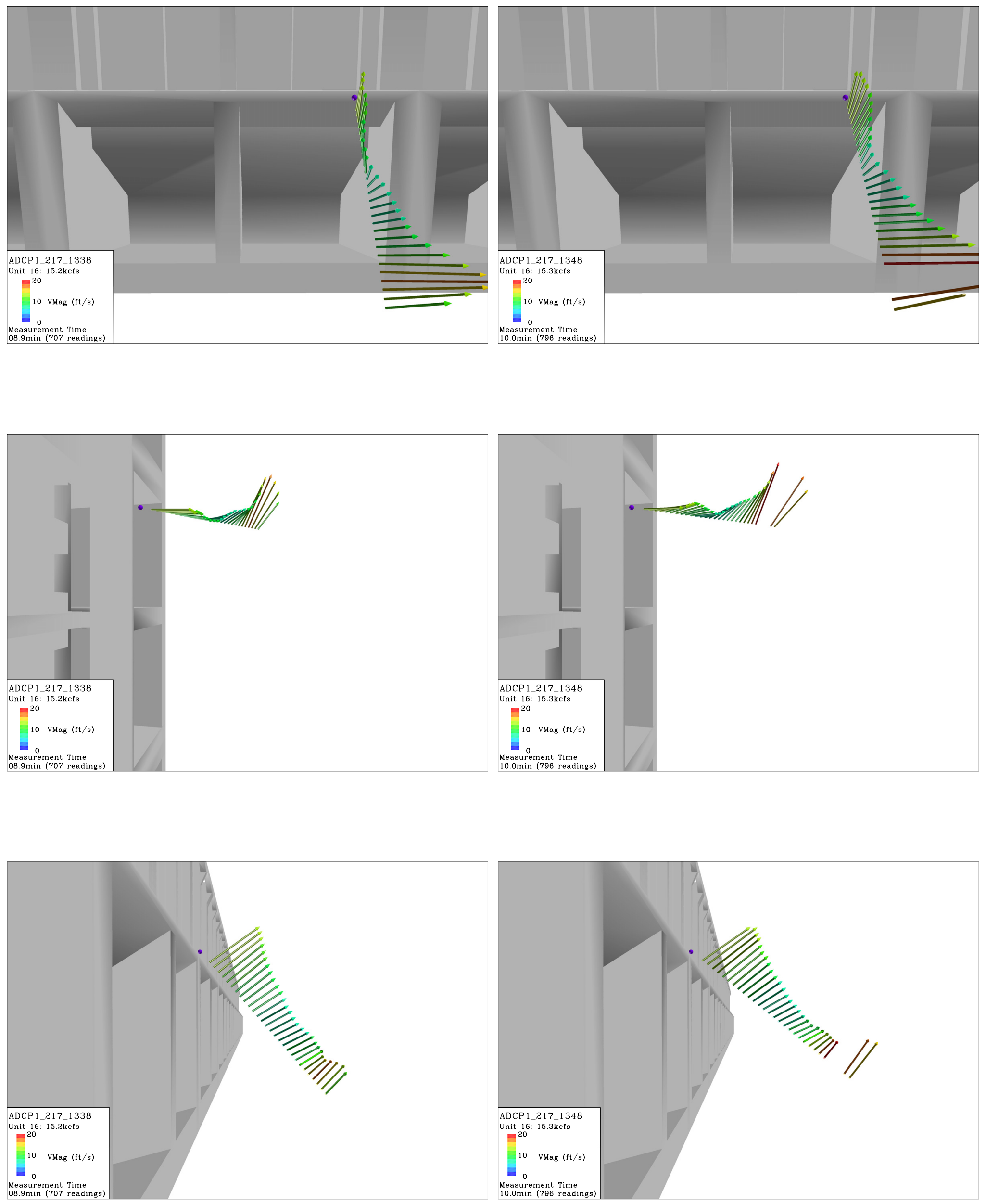

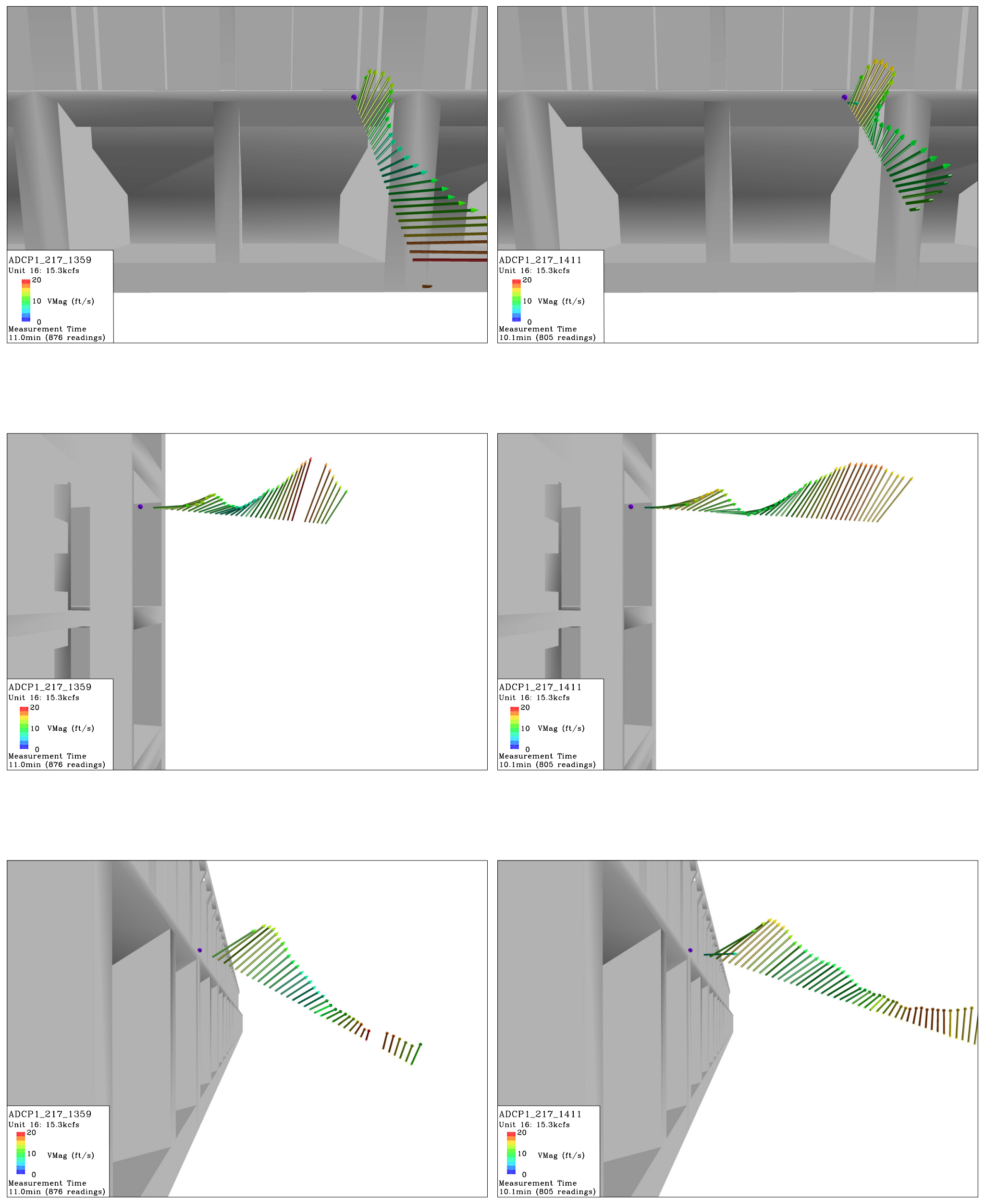

B.9 

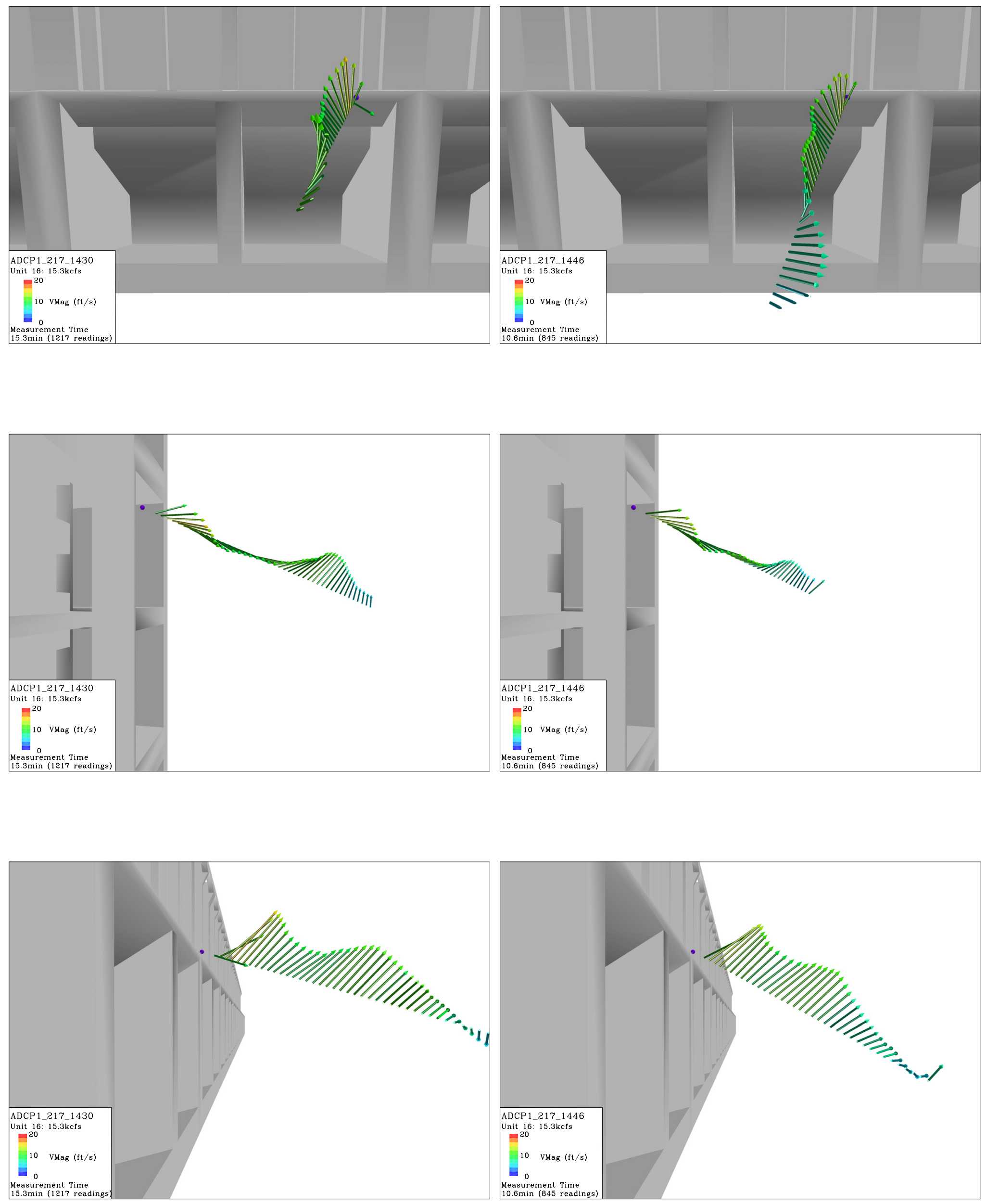

B. 10 

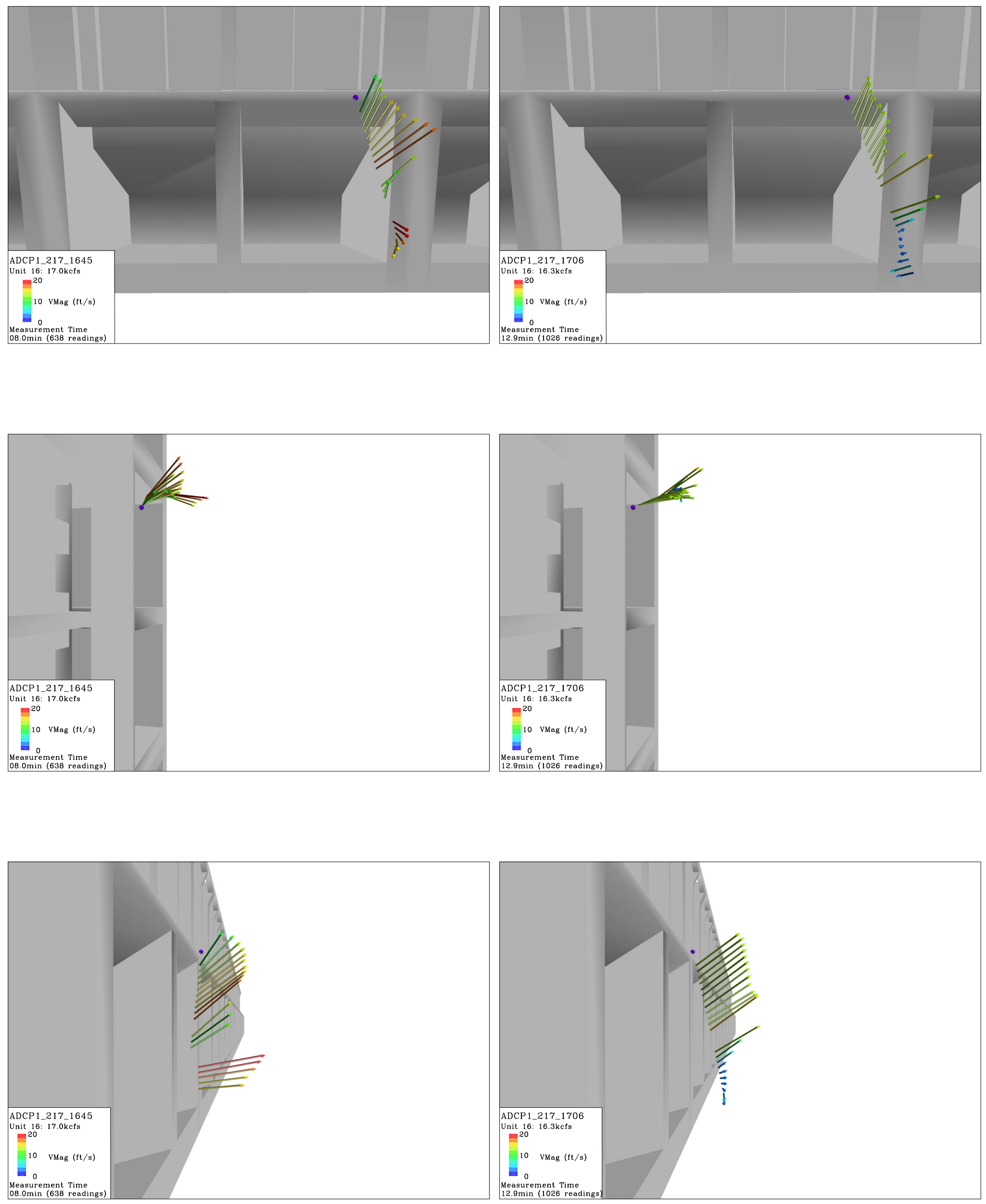

B. 11 

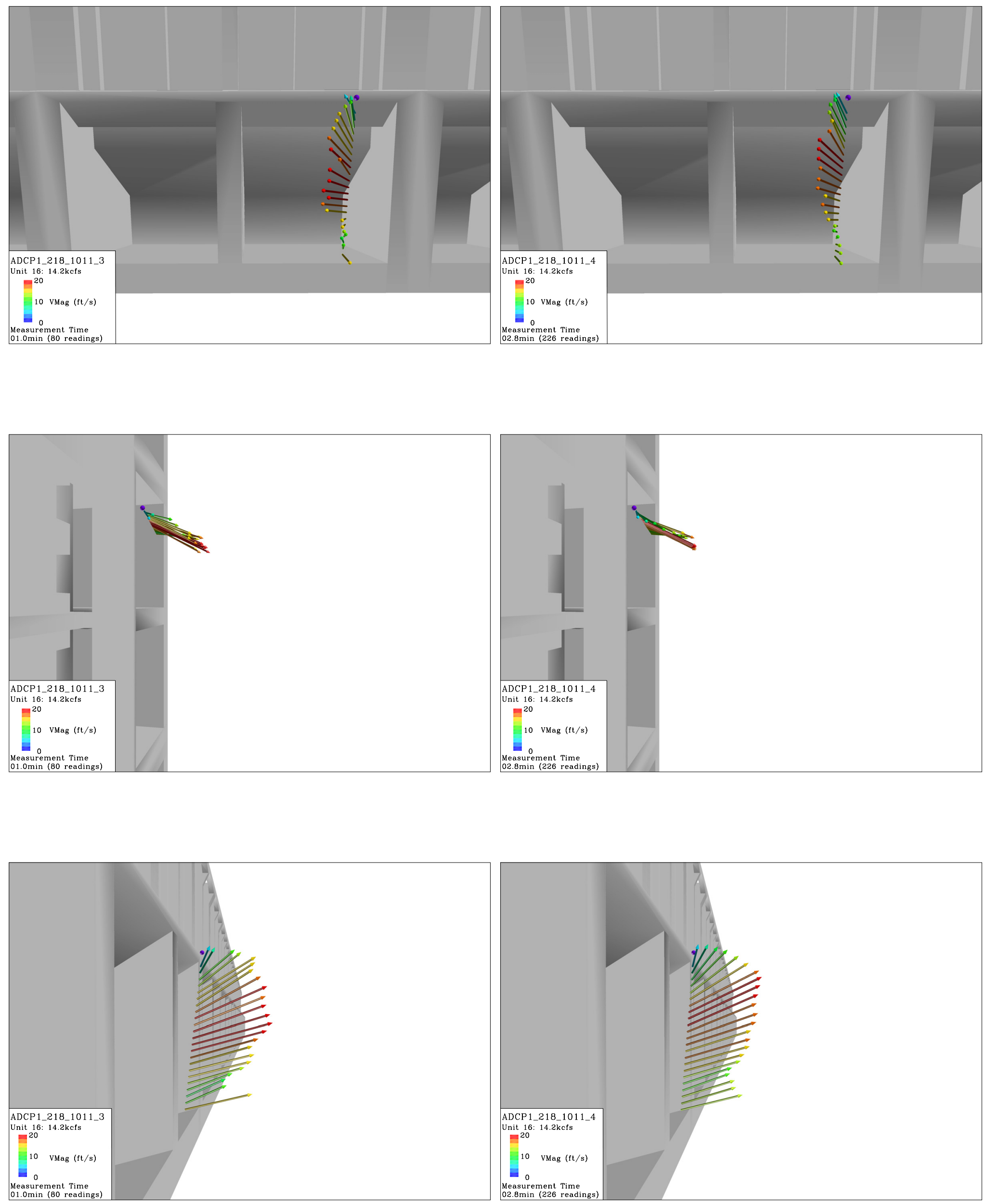

B. 12 

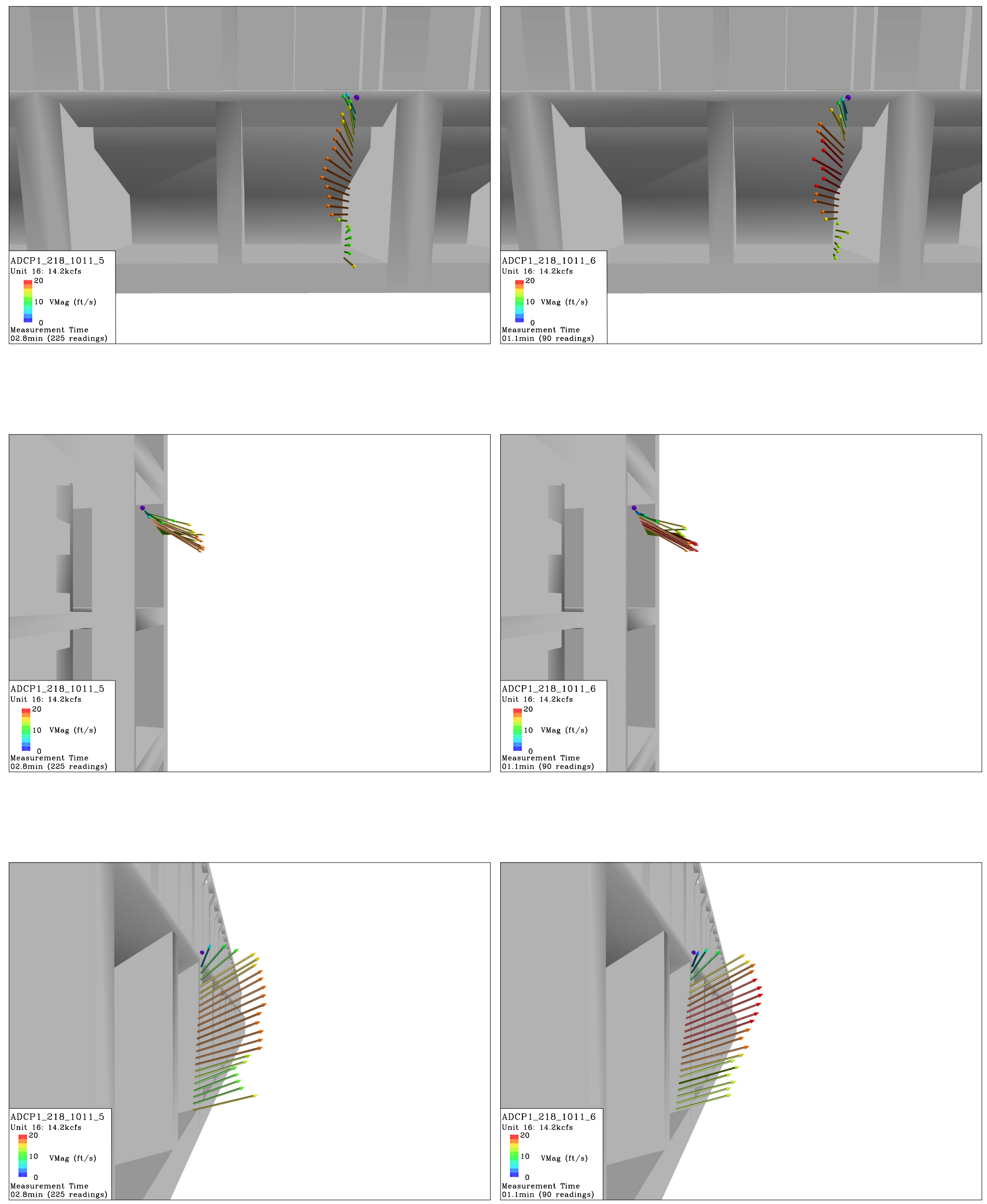

B.13 

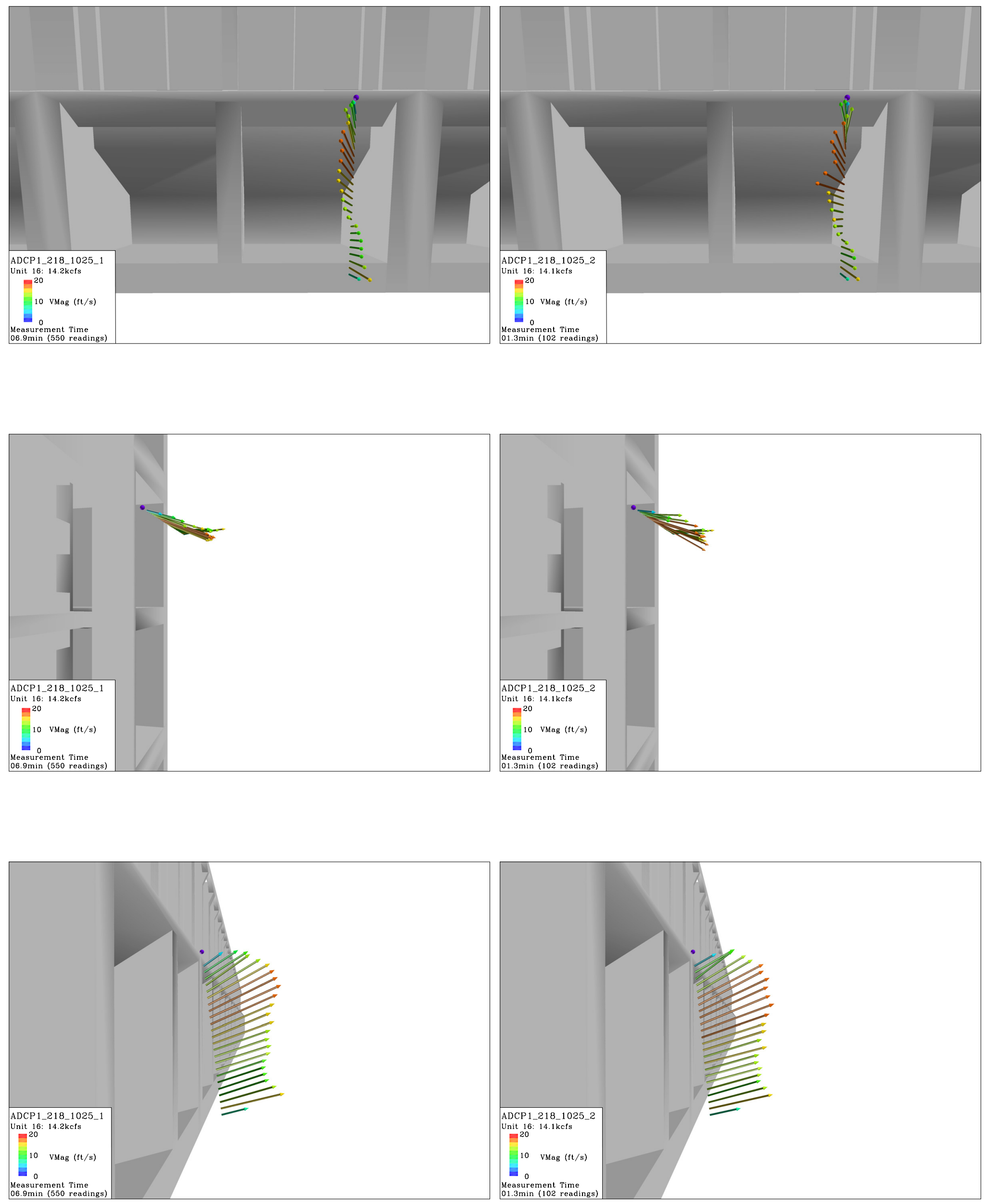

B.14 

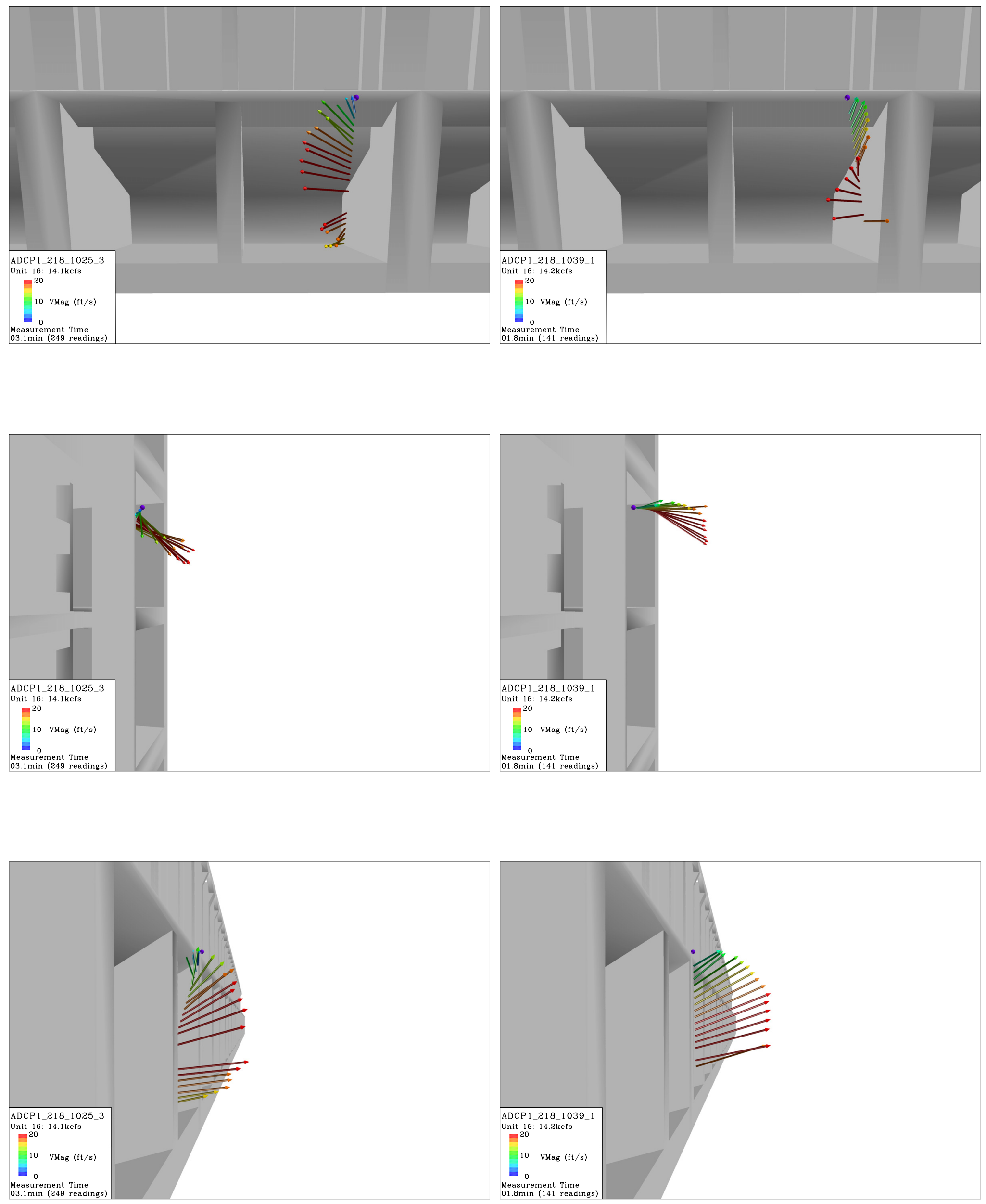

B.15 

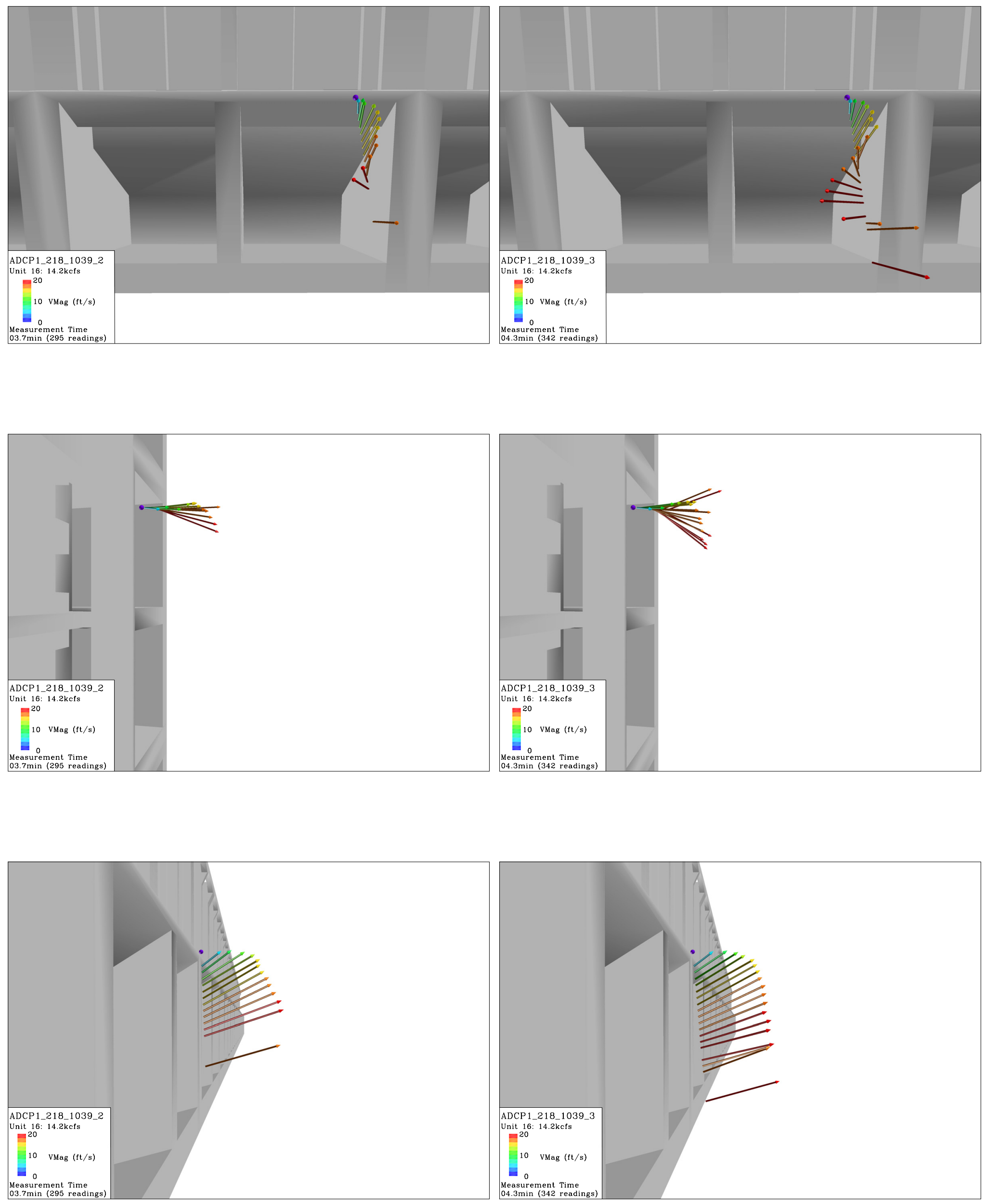

B. 16 

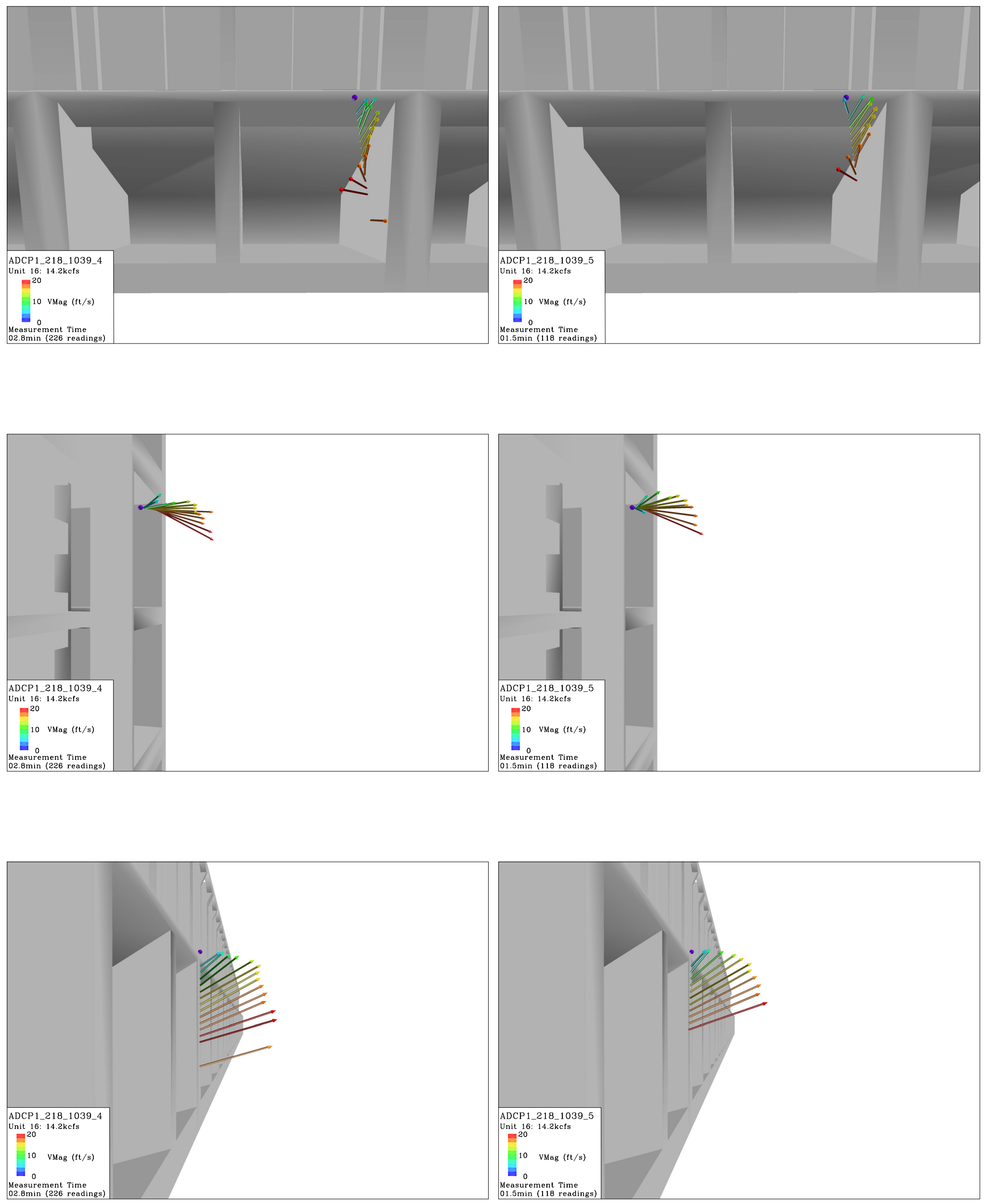

B. 17 

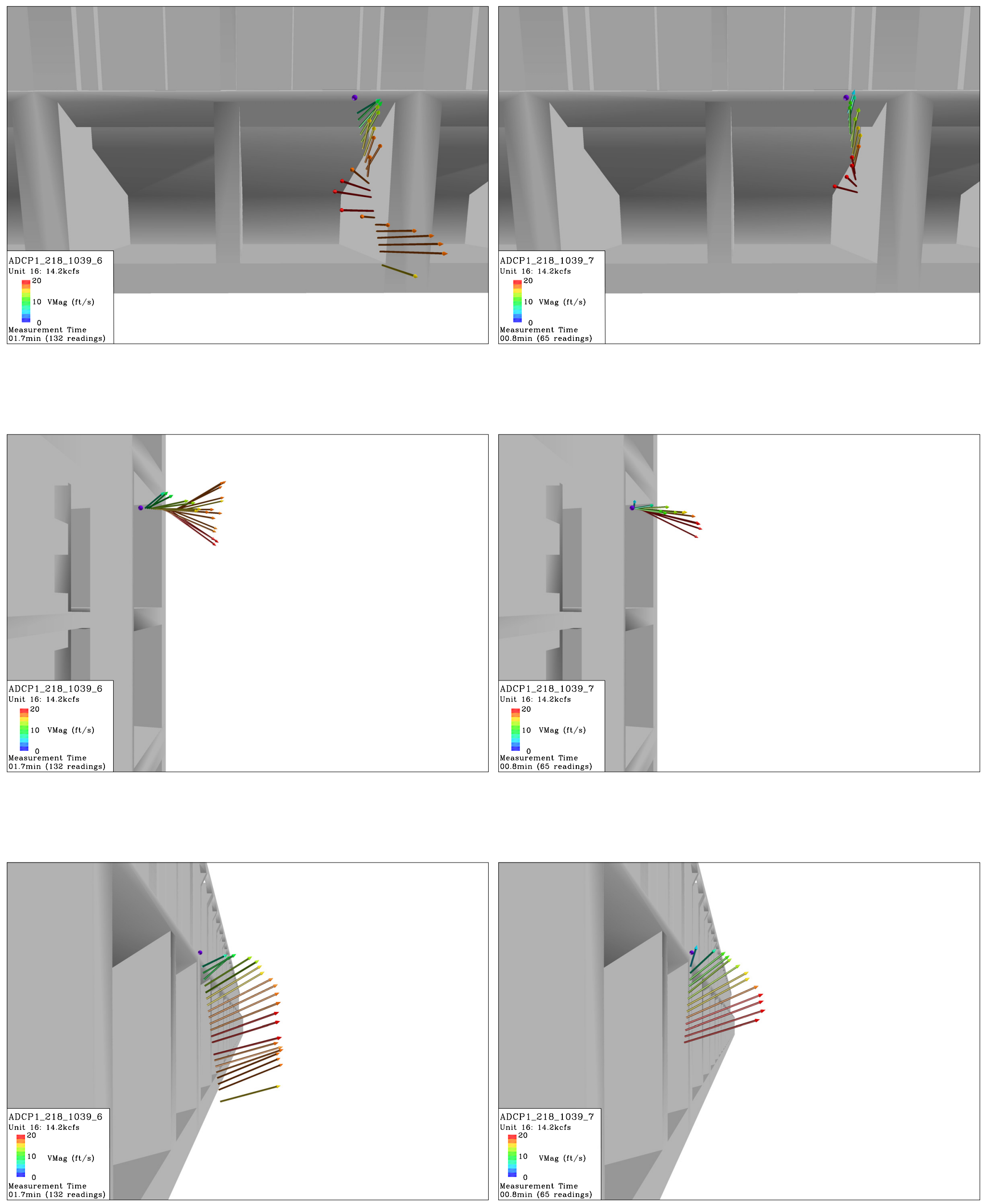

B.18 

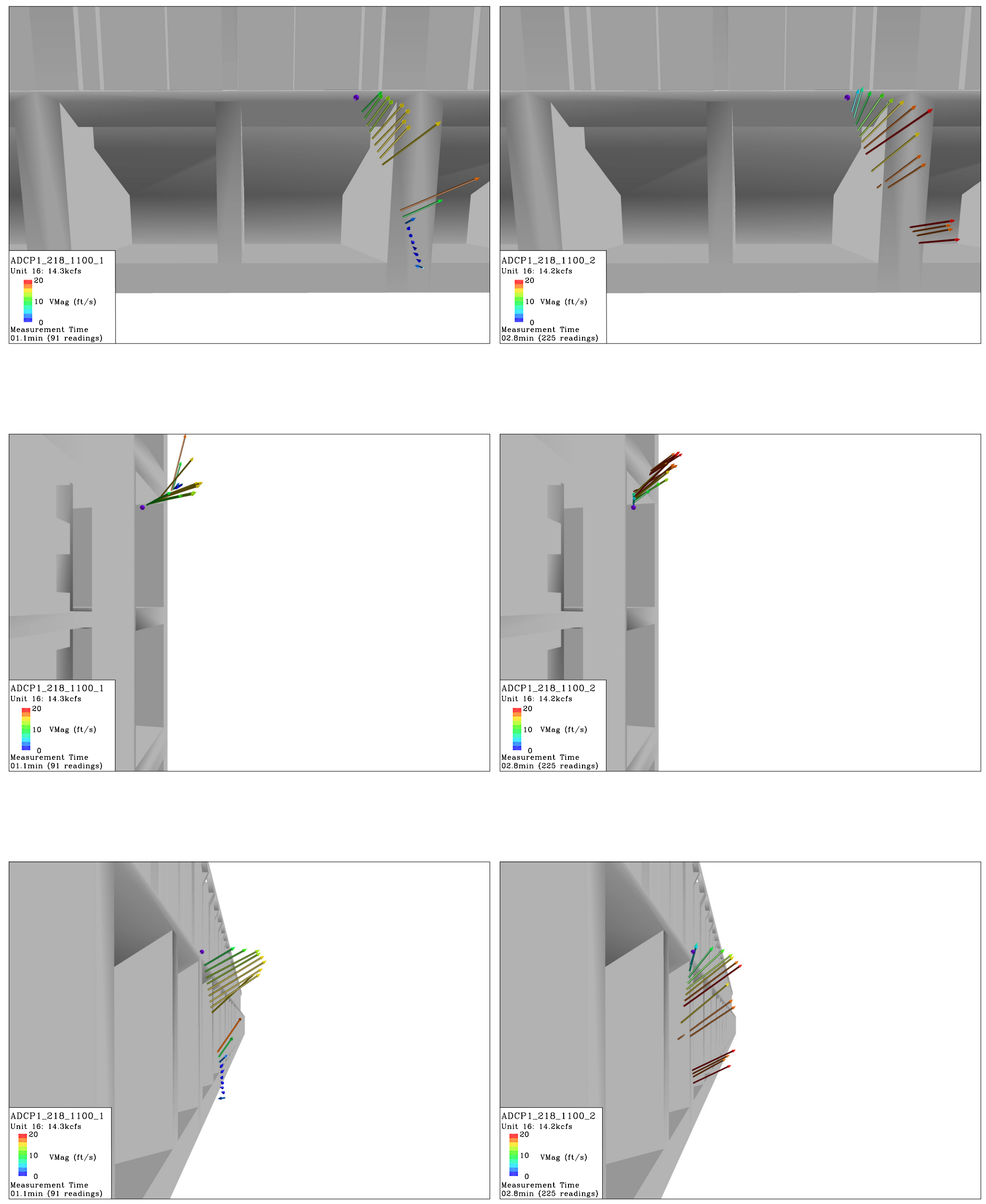

B.19 

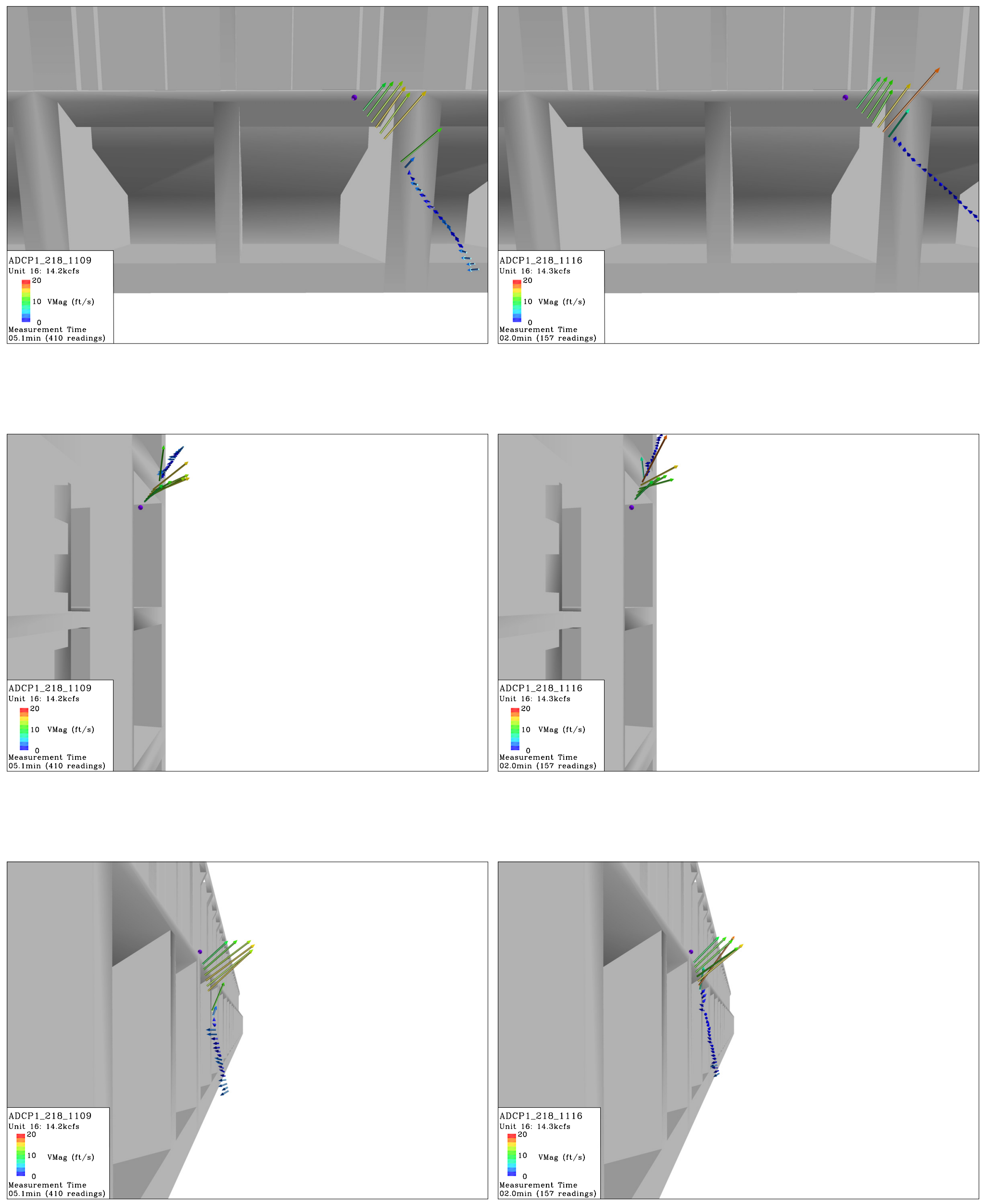

B. 20 

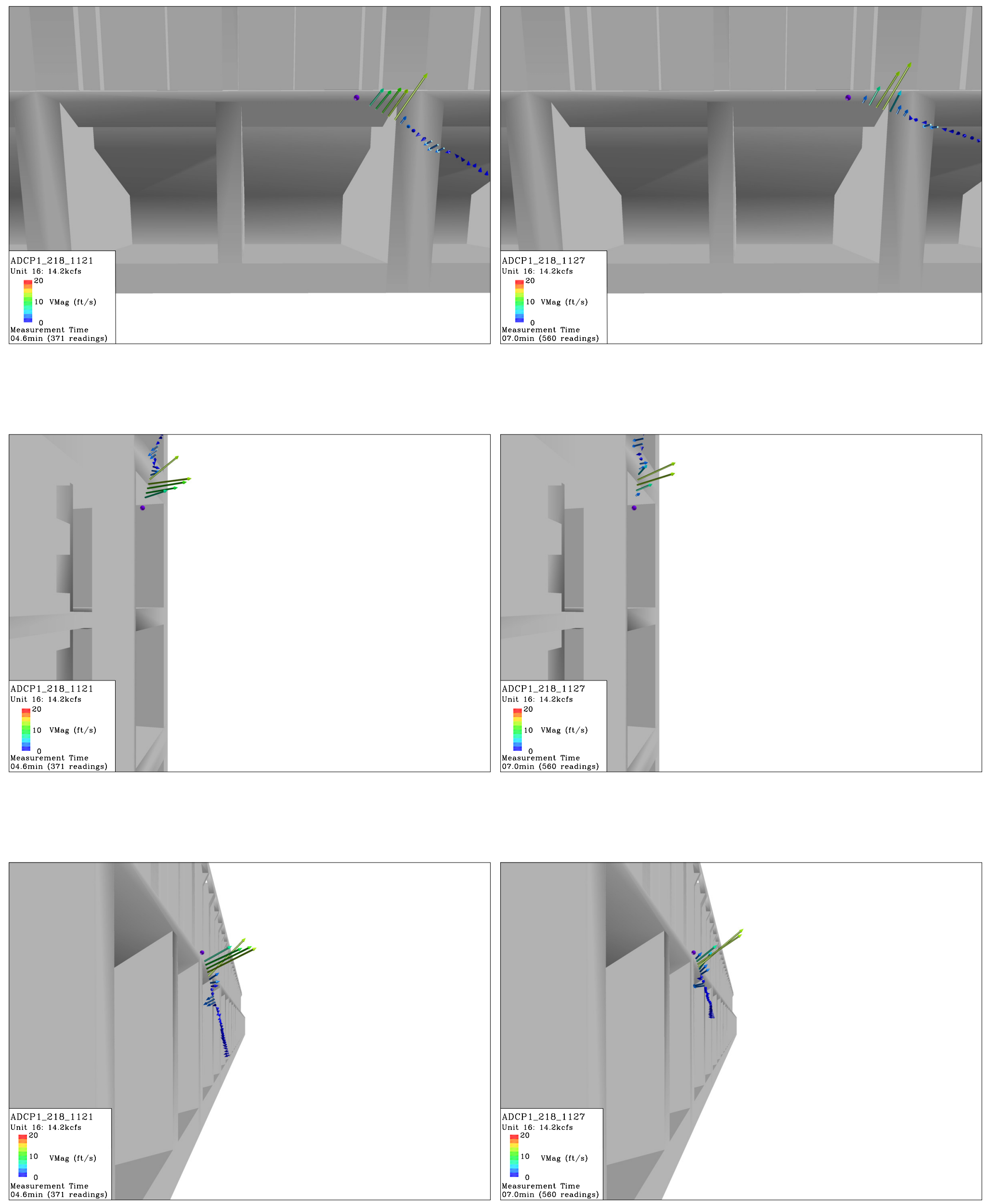

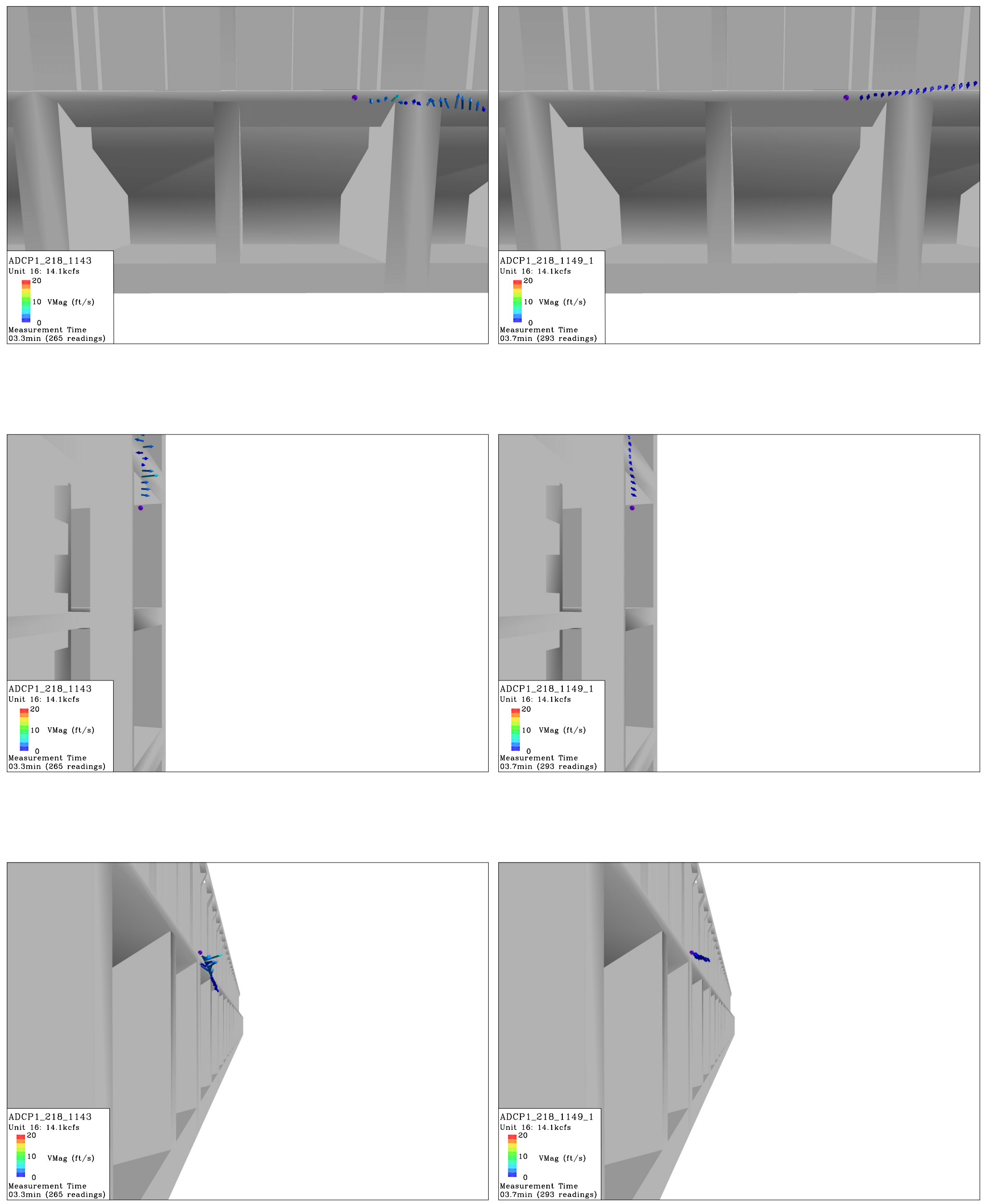

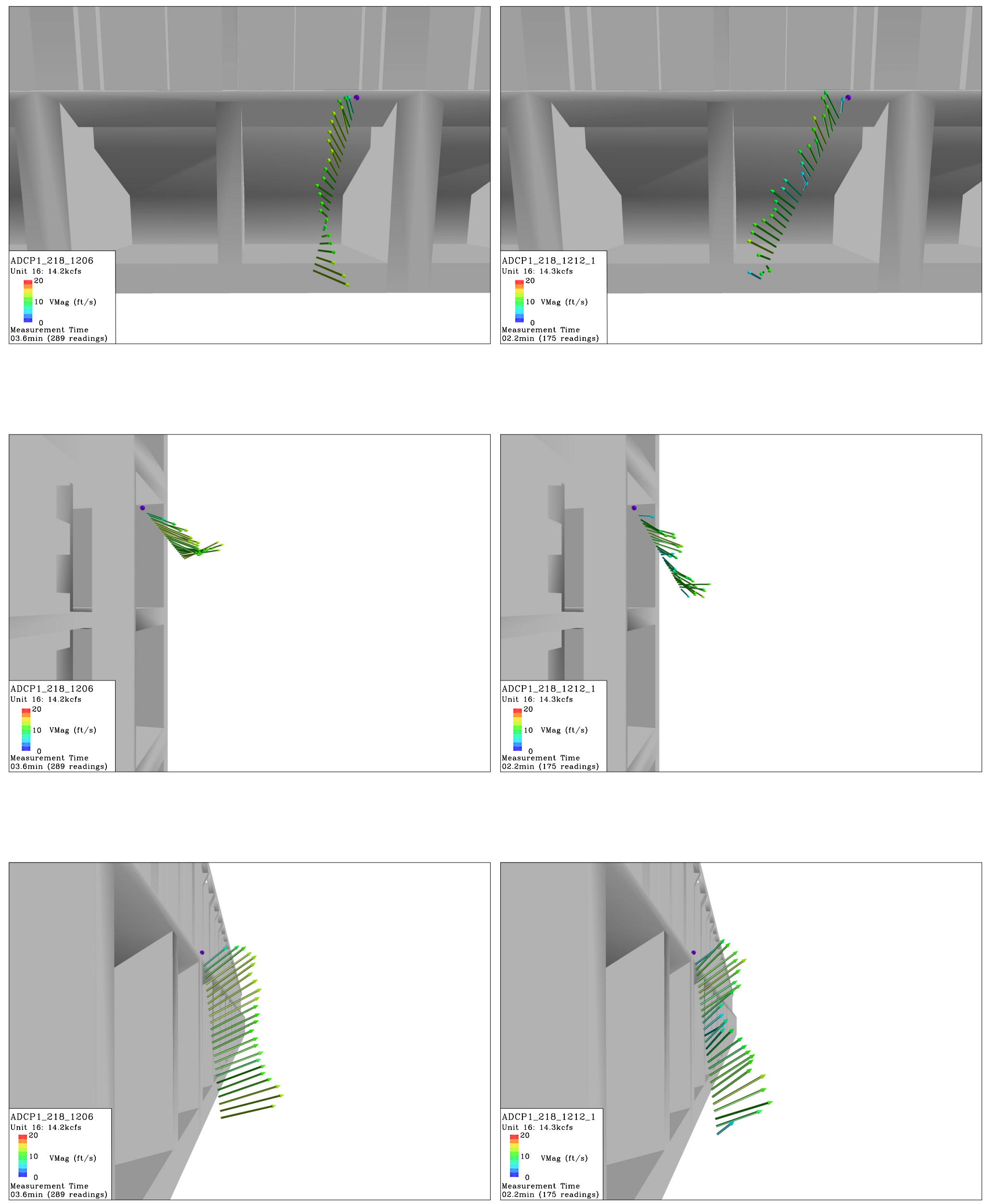

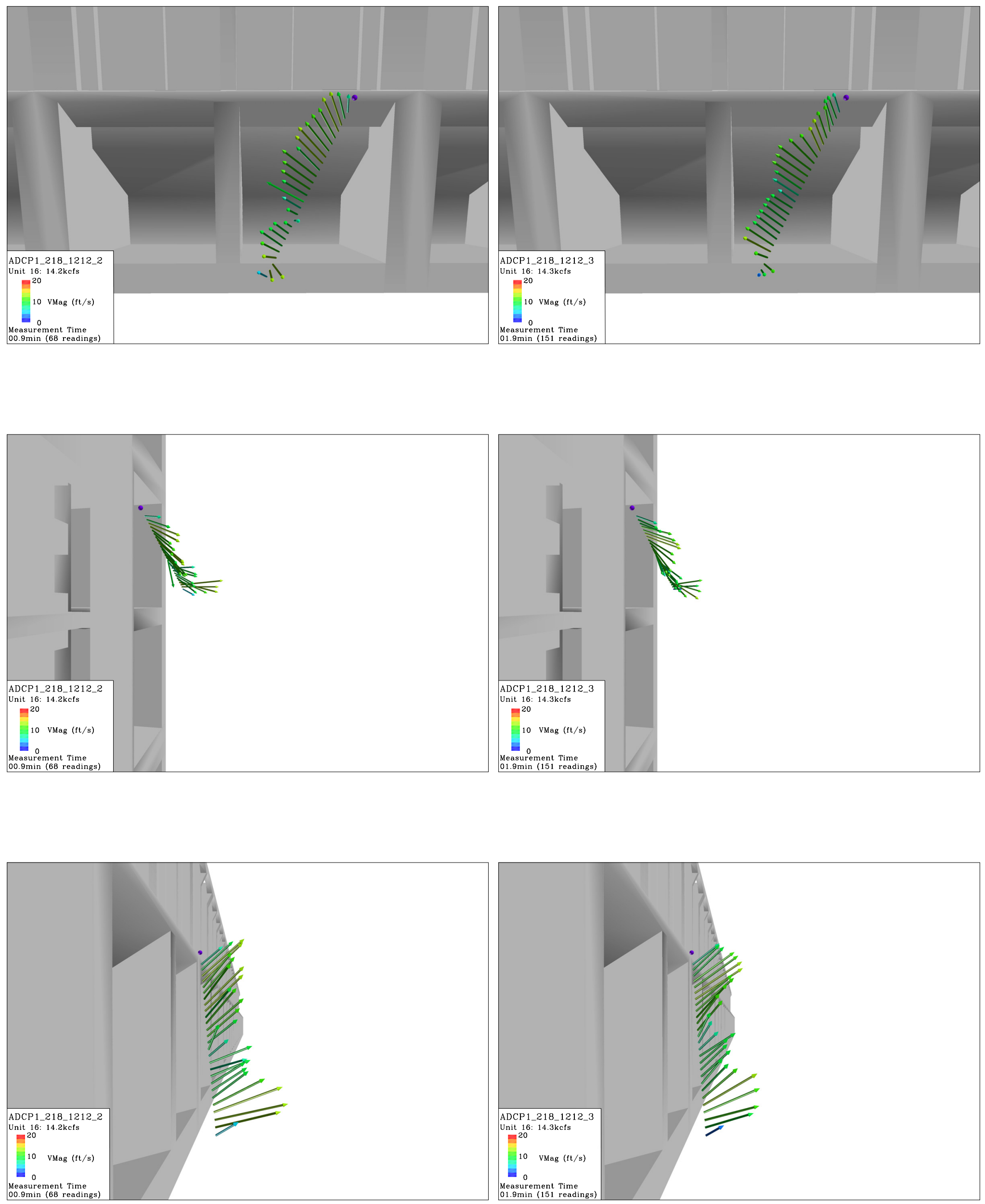

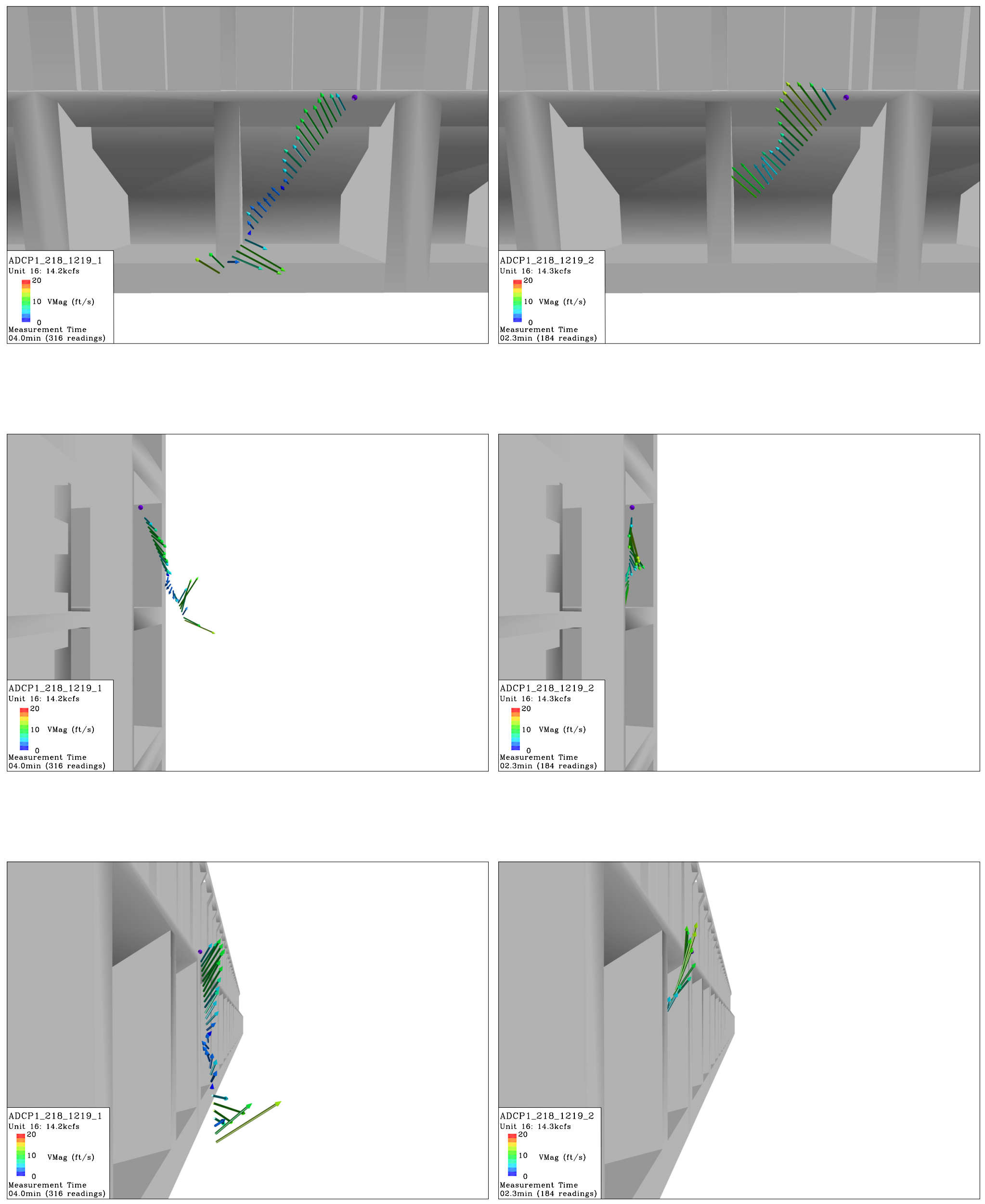

B. 25 

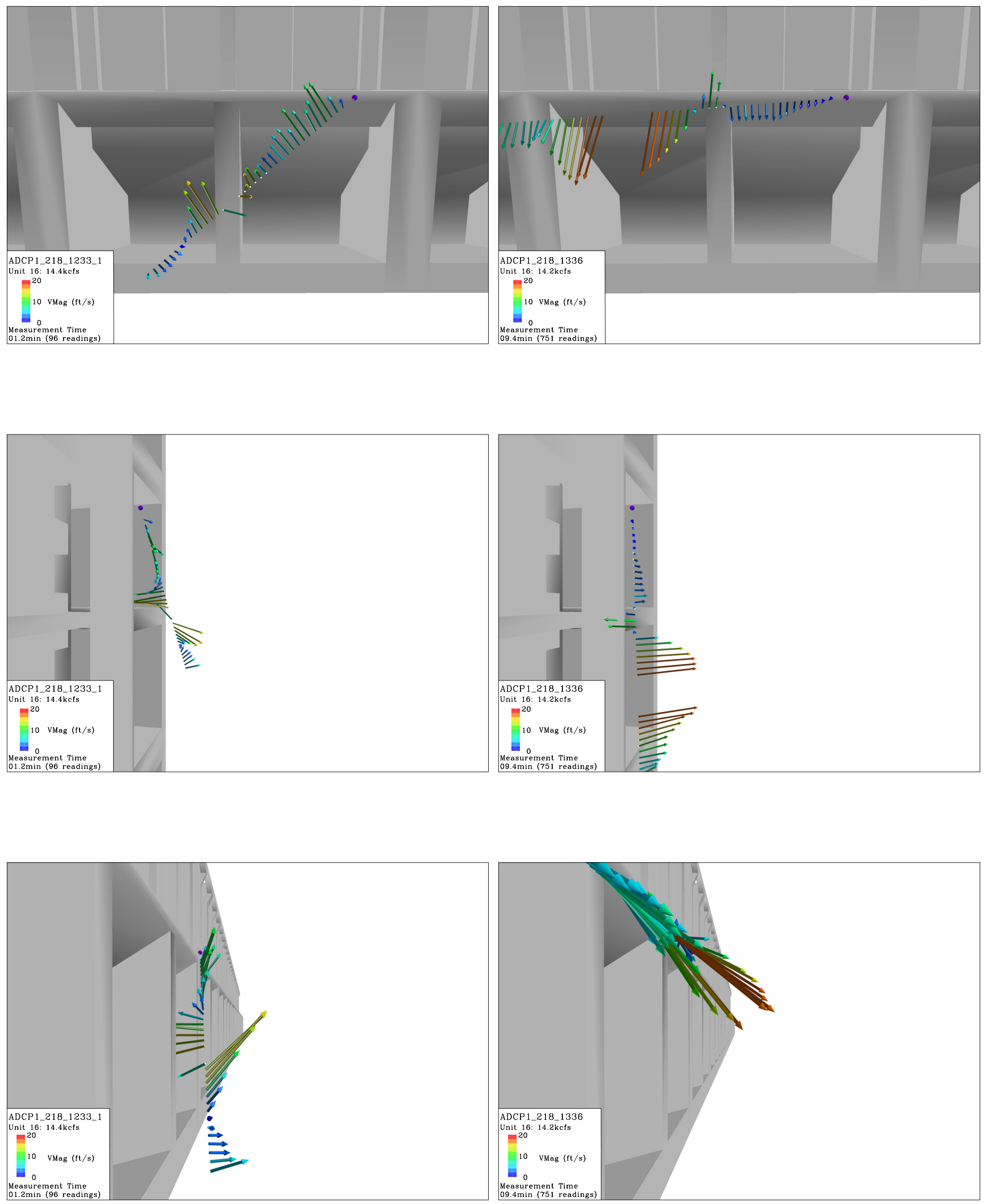

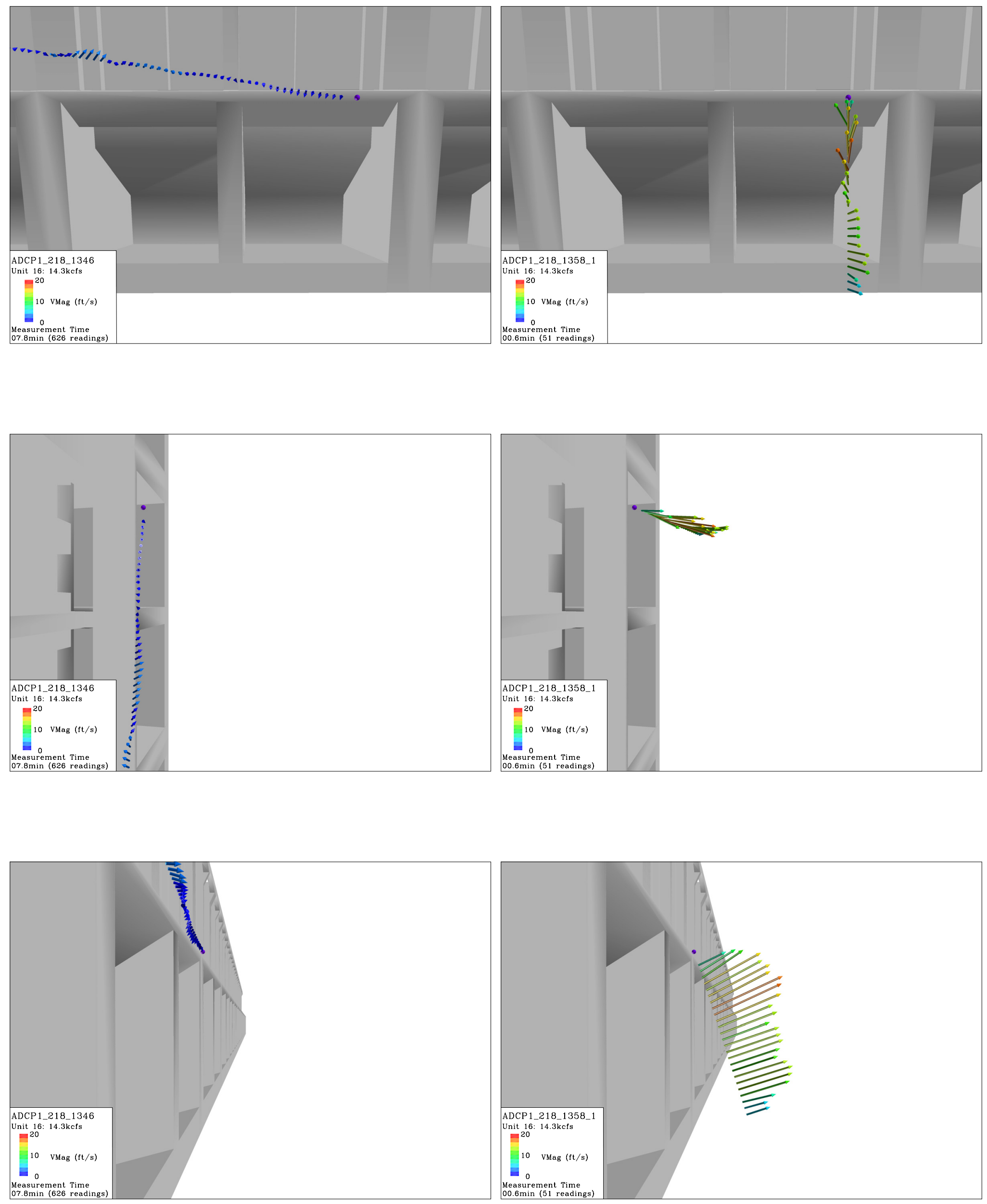

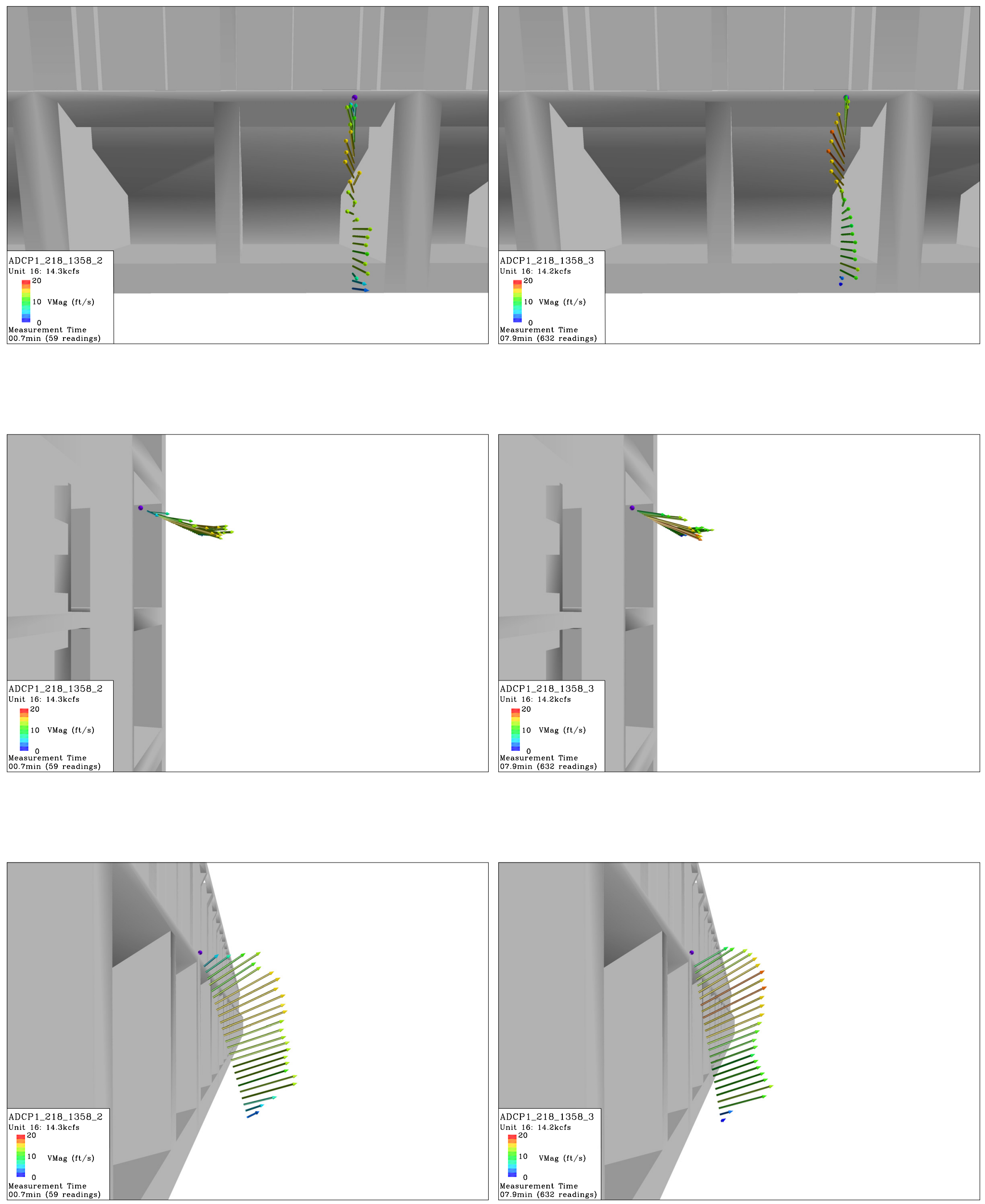

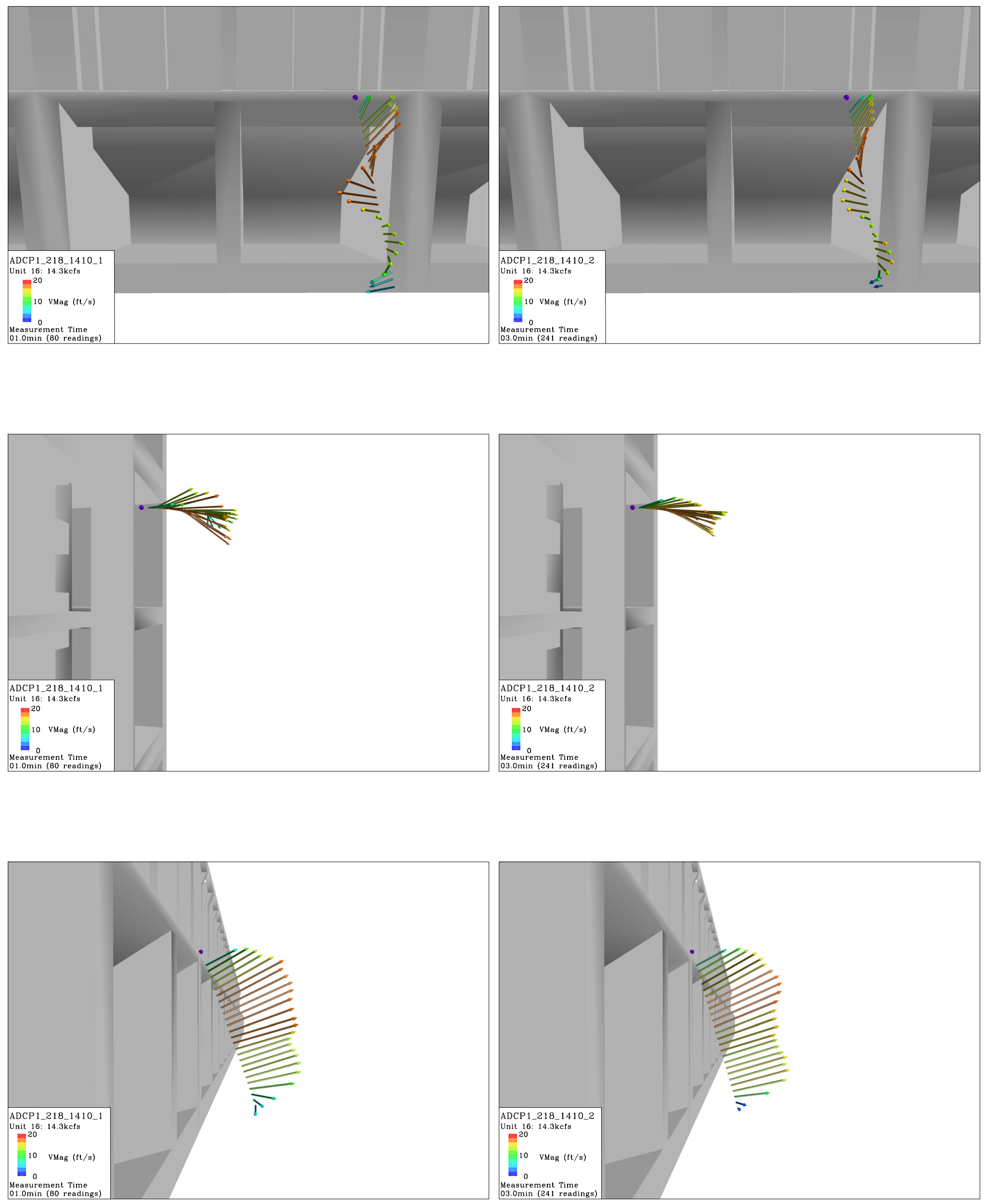

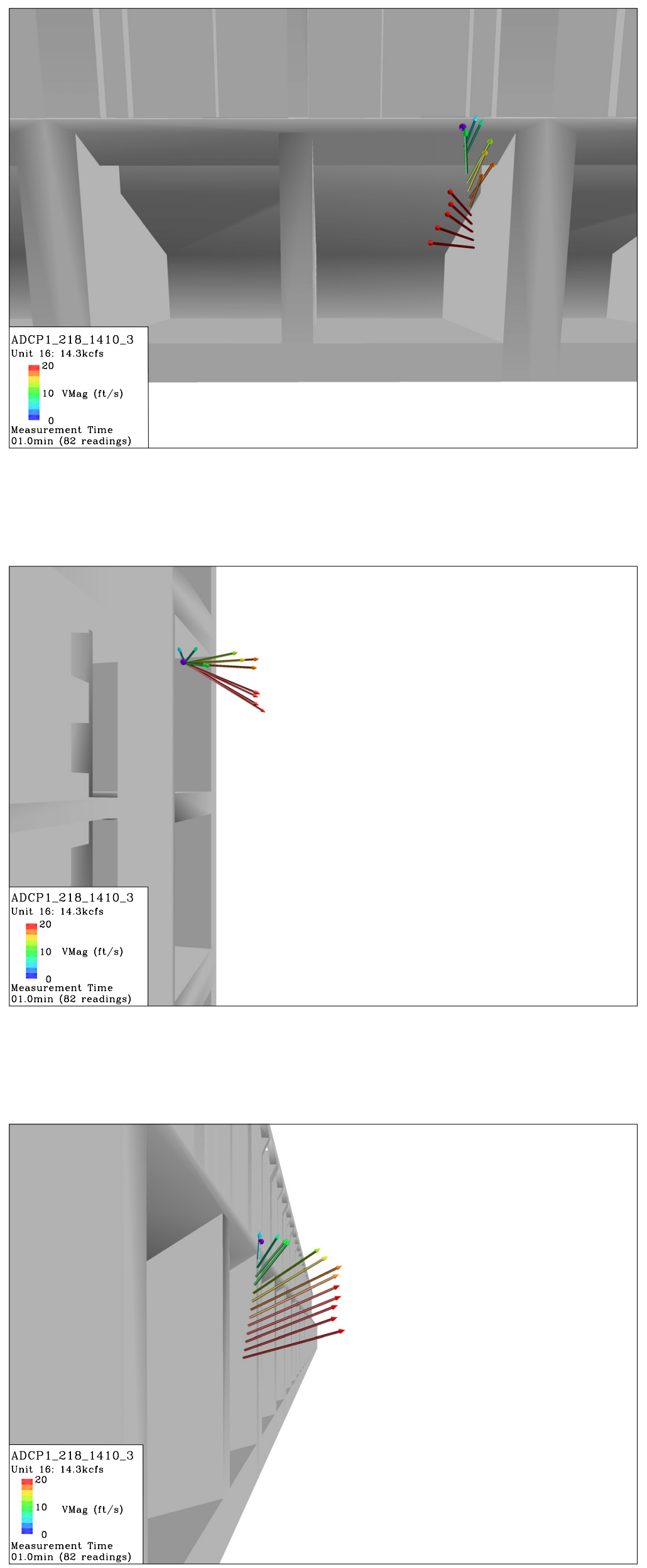

B. 30 
Appendix C

John Day Dam Operations 


\section{Appendix C}

\section{John Day Dam Operations}

Project operations were automatically collected via the Generic Data Acquisition and Control System (GDACS) during the study period (February 17, 28, 22, 23, and 24, 2005). These data are reported in this Appendix. However since Spillbays 11 through 20 were off during the entire period, their values are not presented.

Units for column values are in the English system of units. Forebay, tailwater, and head units are in feet. Columns T01 through T16 present discharge through the turbines in units of kcfs. Columns S1 through S10 present discharge passing through the spillbays, which were off except during the two 6-hr periods on February 17 and 18, 2005. 


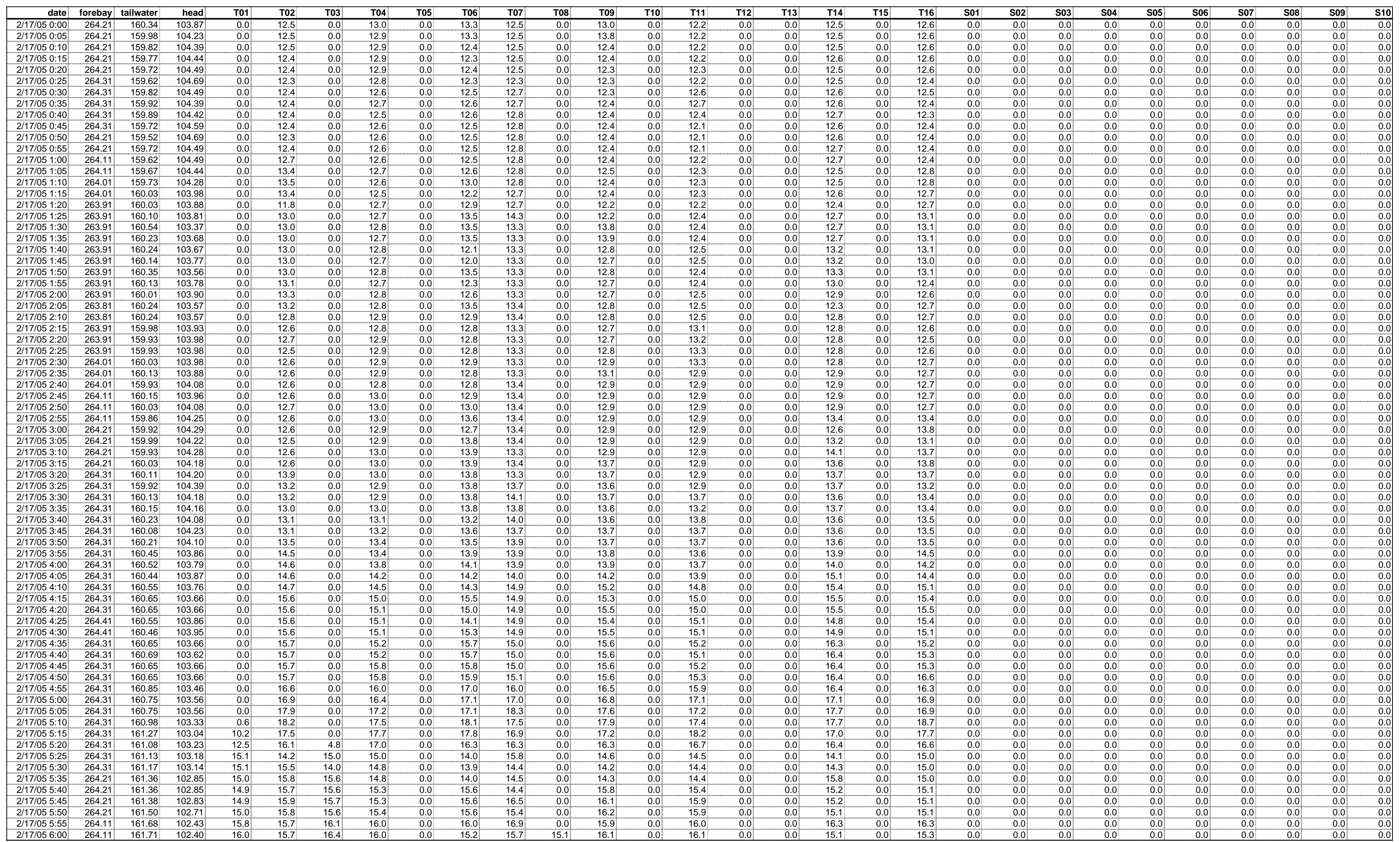




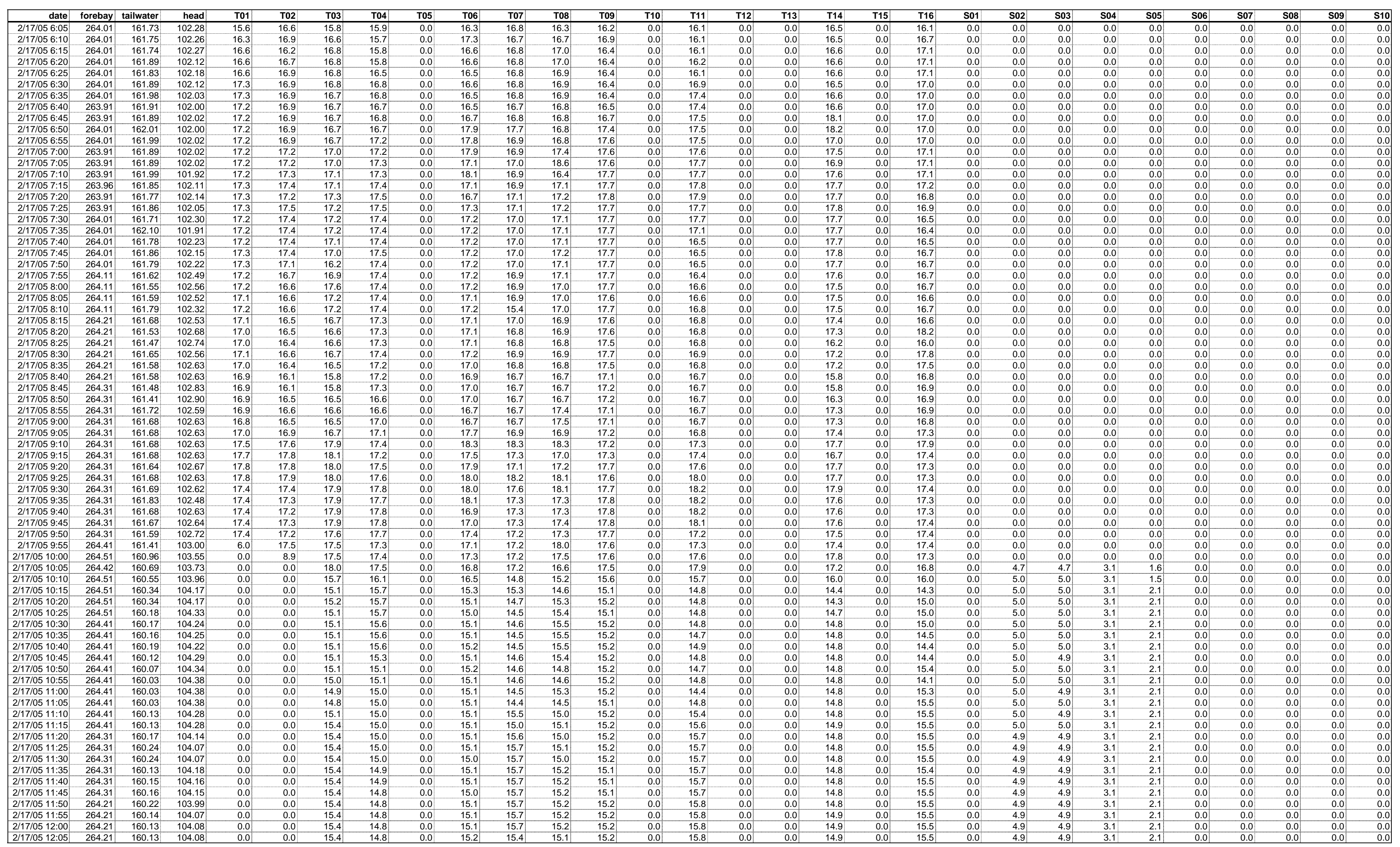




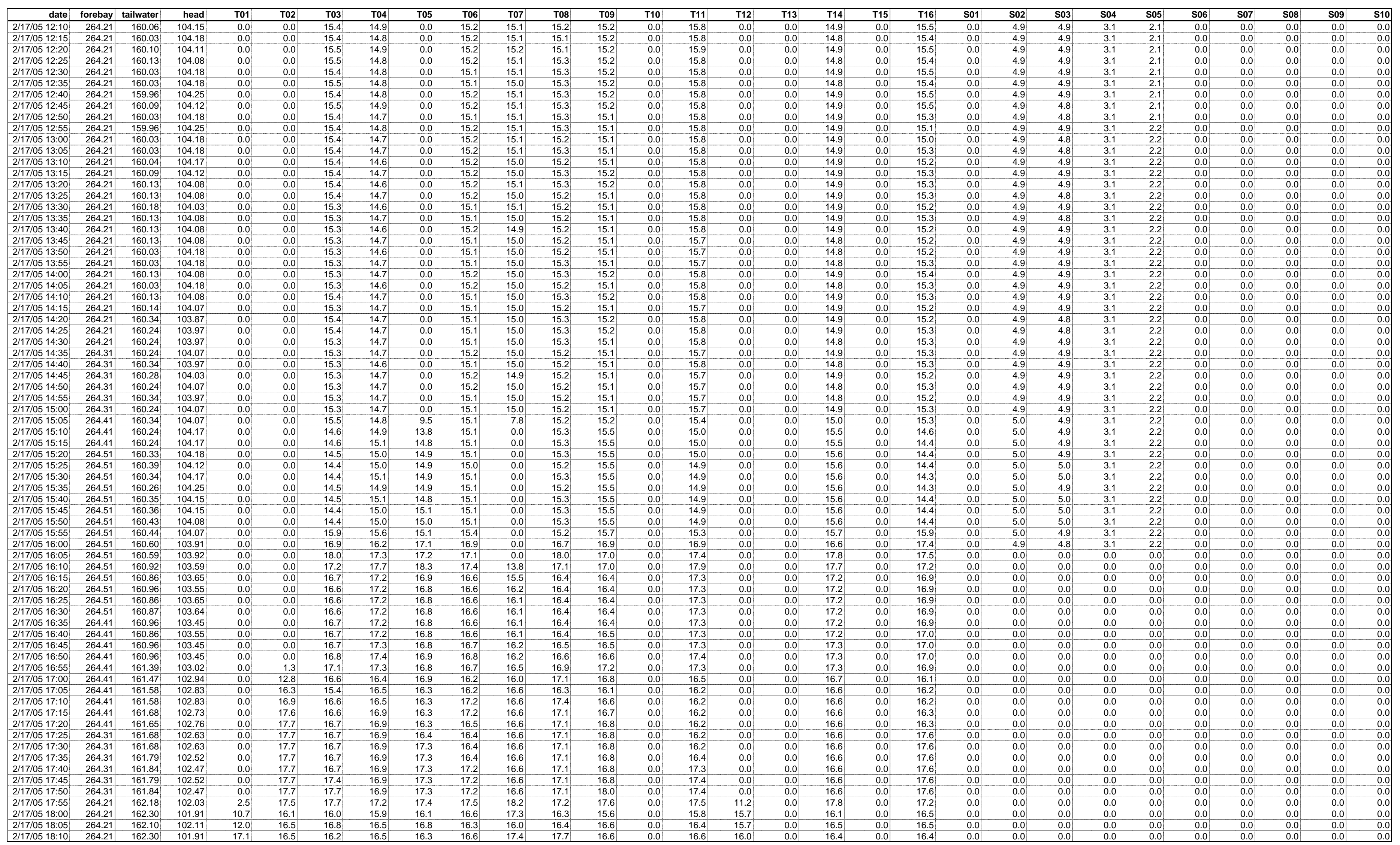




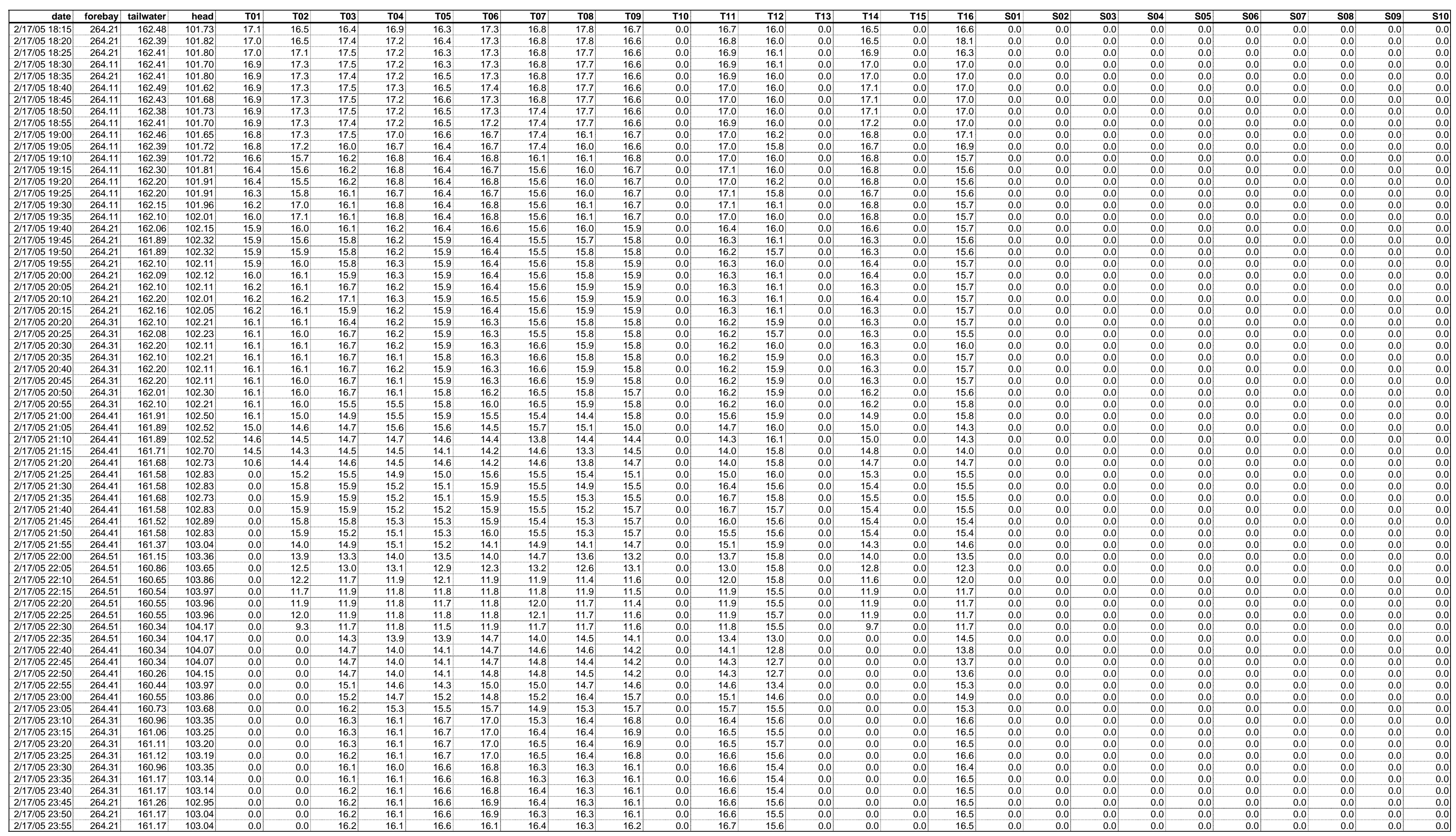




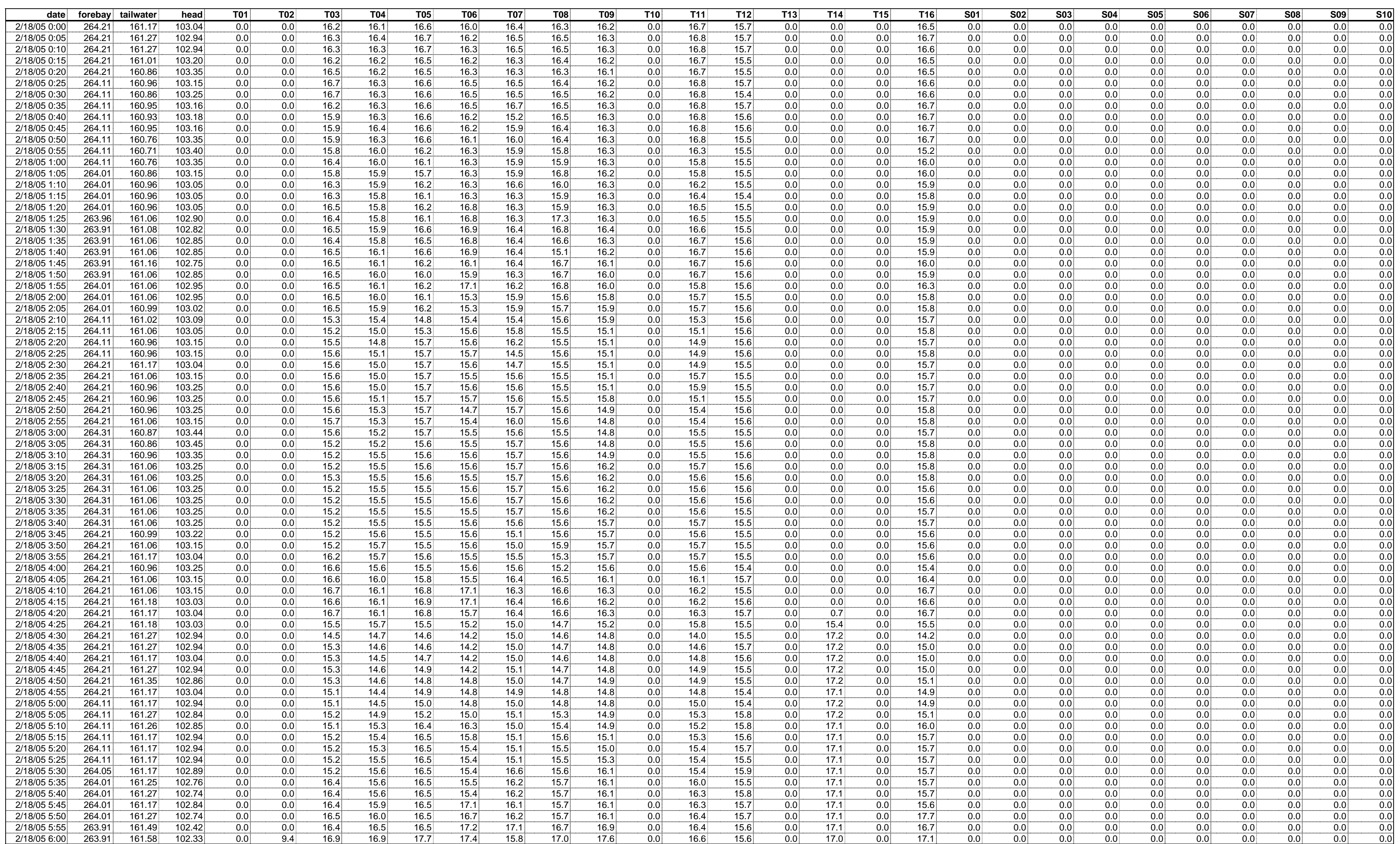




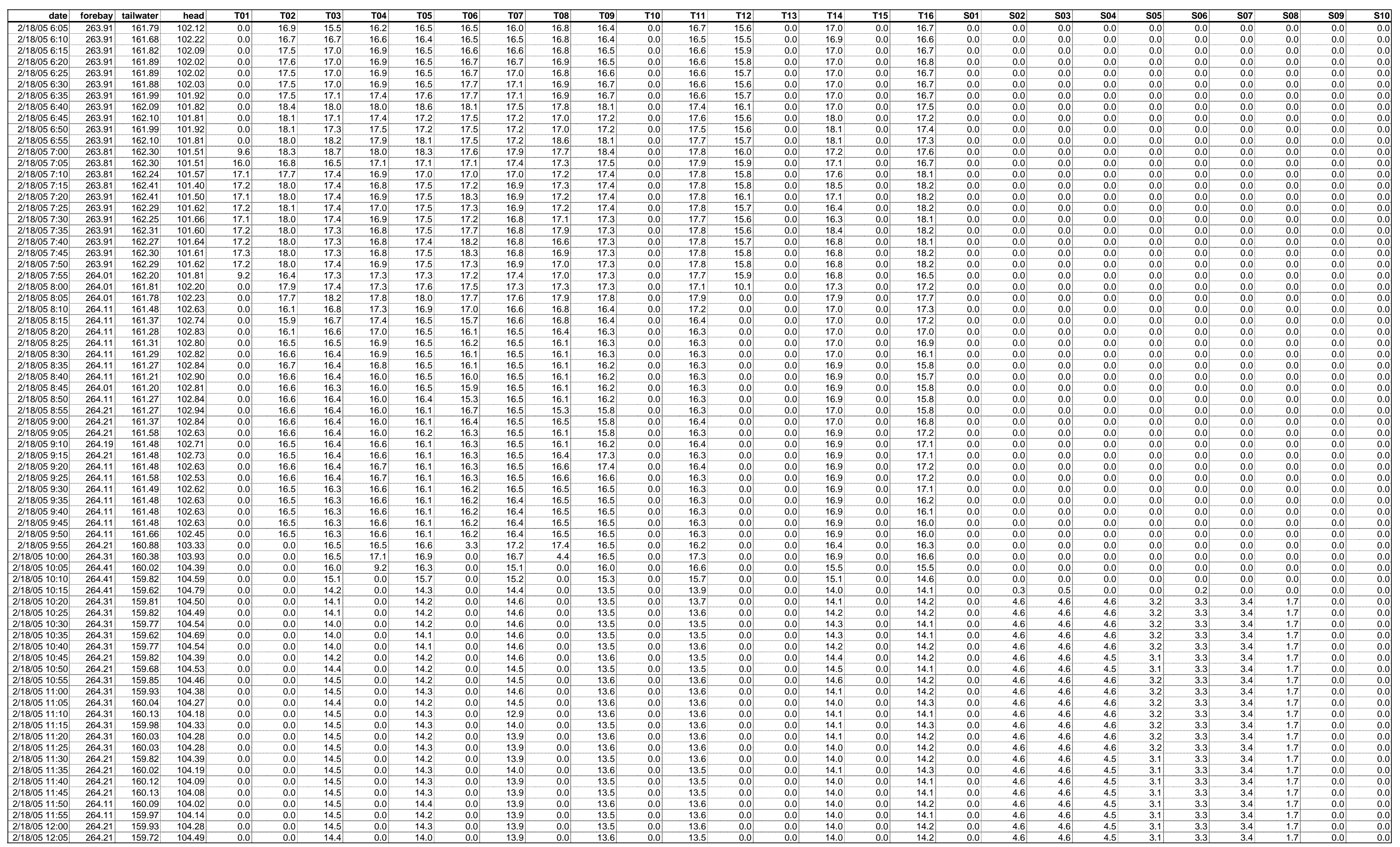




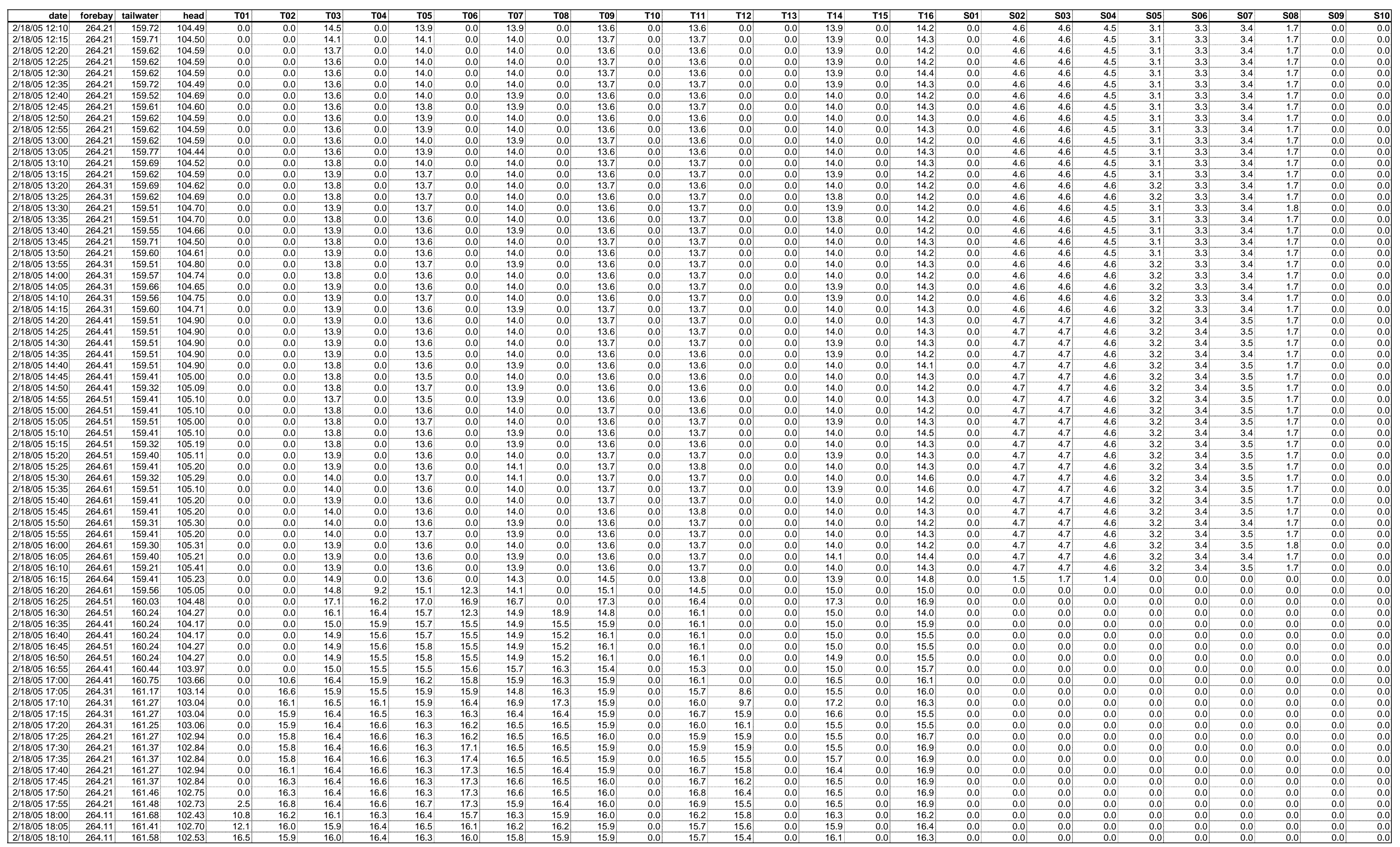




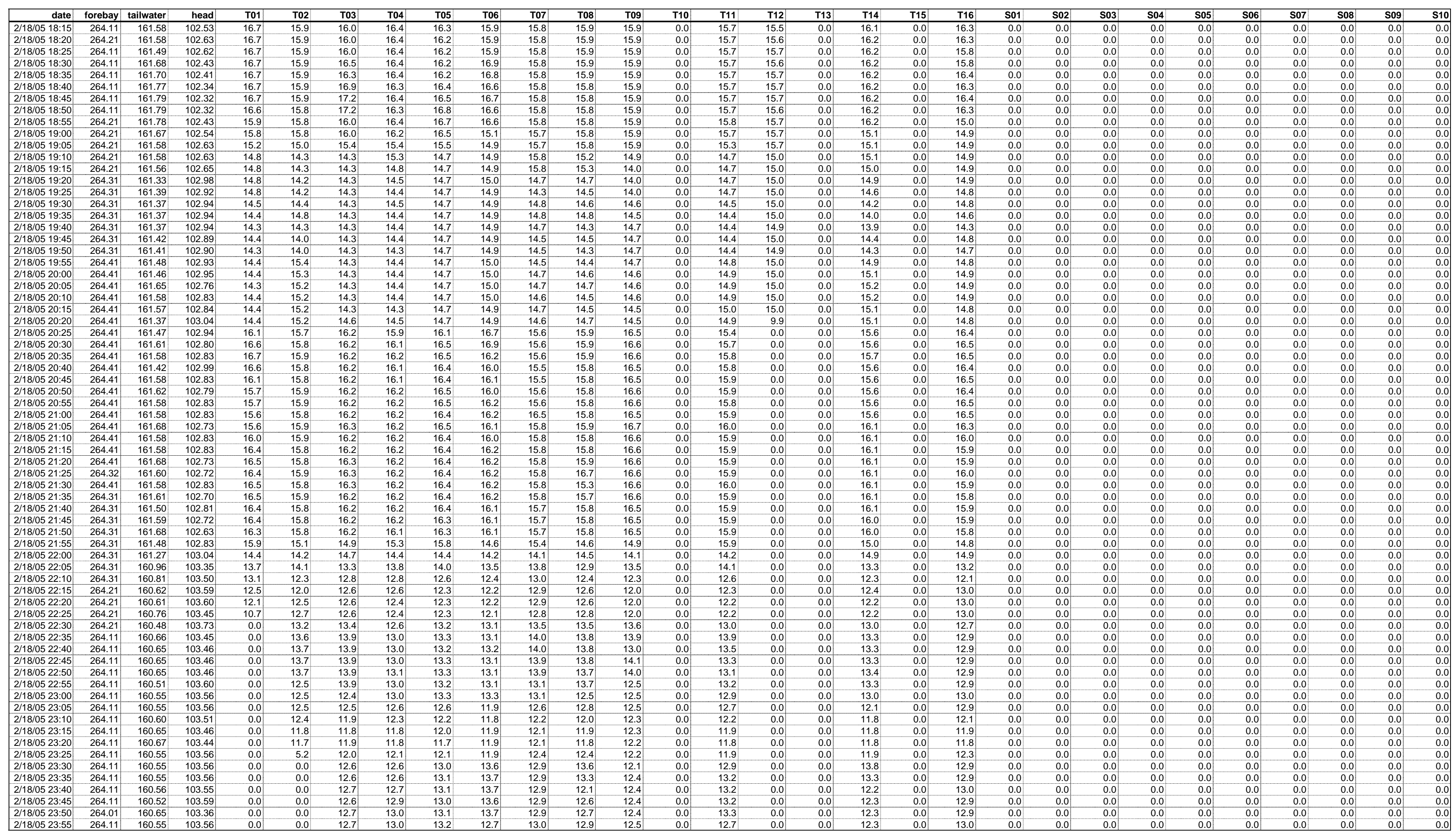




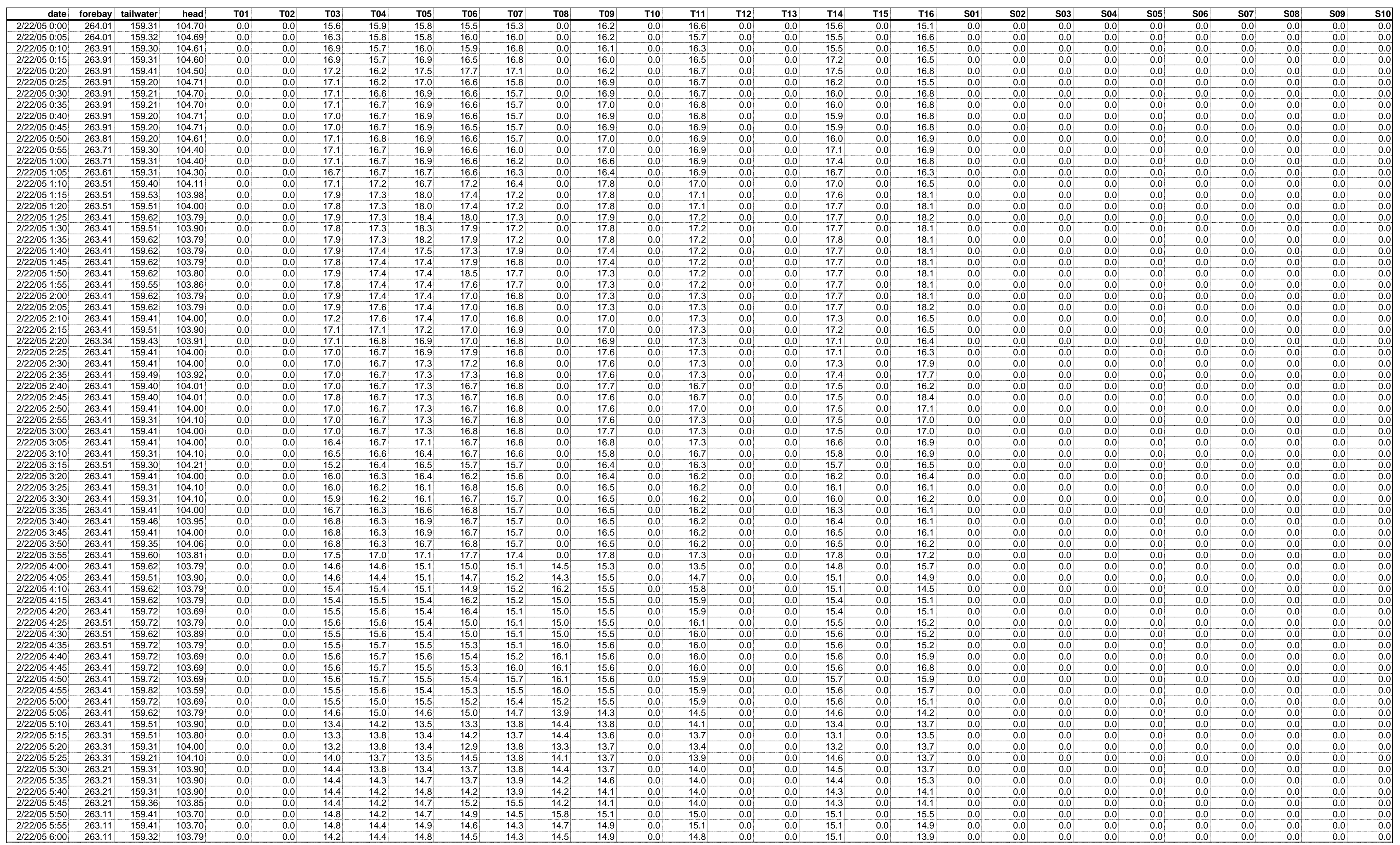




\begin{tabular}{|c|c|c|c|c|c|c|c|c|c|c|c|c|c|c|c|c|c|c|c|c|c|c|c|c|c|c|c|c|c|}
\hline & forebay & tailwater & ead & $\overline{T 01}$ & T02 & T03 & T04 & T05 & T06 & T07 & $\begin{array}{ll}\text { T08 } \\
\end{array}$ & T09 & T10 & \begin{tabular}{l|l|l} 
T11 \\
\end{tabular} & T12 & T13 & T14 & T15 & $\mathrm{T} 16$ & & S02 & 503 & S04 & & 506 & S07 & 508 & 509 & S10 \\
\hline $1056: 05$ & & & 103.77 & 0.0 & 0.0 & 14.4 & 14.4 & 14.7 & & 14.4 & 14.5 & 13.7 & 0.0 & & & 0.0 & 14.6 & 0.0 & & 0.0 & 0.0 & 0.0 & 0.0 & $\frac{0.0}{0.0}$ & $\frac{0.0}{0.0}$ & $\frac{0}{0.0}$ & $\frac{0.0}{0.0}$ & 0.0 & \begin{tabular}{|c|}
510 \\
0.0
\end{tabular} \\
\hline $056: 10$ & 263.01 & 159.46 & 103.55 & 0.0 & 0.0 & 15.4 & 14.5 & 14.8 & 15.2 & 15.0 & 15.2 & 15.3 & 0.0 & 14.8 & 0.0 & 0.0 & 15.2 & 0.0 & 15.4 & 0.0 & 0.0 & 0.0 & 0.0 & 0.0 & 0.0 & 0.0 & 0.0 & 0.0 & 0.0 \\
\hline $\begin{array}{l}6: 15 \\
66 \cdot 20\end{array}$ & $\begin{array}{r}263.01 \\
226.01\end{array}$ & 15044 & $\begin{array}{l}103.52 \\
103.57\end{array}$ & $\begin{array}{l}0.0 \\
0.0\end{array}$ & 0.0 & $\begin{array}{l}15.3 \\
14.6\end{array}$ & $\begin{array}{l}14.5 \\
14.5 \\
\end{array}$ & $\begin{array}{l}14.6 \\
148\end{array}$ & $\begin{array}{l}15.2 \\
15.1\end{array}$ & $\begin{array}{l}15.0 \\
149\end{array}$ & $\begin{array}{l}14.8 \\
14.6\end{array}$ & $\begin{array}{l}14.7 \\
1149\end{array}$ & $\begin{array}{l}0.0 \\
0.0\end{array}$ & $\begin{array}{l}14.4 \\
150\end{array}$ & 0.0 & 0.0 & $\begin{array}{l}14.4 \\
15 .\end{array}$ & $\begin{array}{l}0.0 \\
0.0\end{array}$ & 14.6 & 0.0 & 0.0 & 0.0 & 0.0 & 0.0 & 0.0 & 0.0 & 0.0 & 0.0 & 0.0 \\
\hline & $\begin{array}{r}263.01 \\
2050.01\end{array}$ & $\begin{array}{l}159.44 \\
15041\end{array}$ & & 0.0 & & & & & & & & $\begin{array}{l}14.9 \\
149\end{array}$ & 0.0 & $\begin{array}{ll}15.0 \\
1.01\end{array}$ & 0.0 & 0.0 & 15.0 & 0.0 & $\begin{array}{l}15.0 \\
15.0\end{array}$ & 0.0 & 0.0 & 0.0 & 0.0 & 0.0 & 0.0 & 0.0 & 0.0 & 0.0 & 0.0 \\
\hline $\begin{array}{l}56: 25 \\
56.30\end{array}$ & $\begin{array}{l}262.91 \\
202501\end{array}$ & $\begin{array}{l}159.41 \\
15.51\end{array}$ & $\begin{array}{l}103.50 \\
10340\end{array}$ & 0.0 & 0.0 & $\begin{array}{l}14.6 \\
1.5\end{array}$ & $\begin{array}{l}14.8 \\
148\end{array}$ & $\begin{array}{l}14.8 \\
153\end{array}$ & $\begin{array}{l}15.0 \\
150\end{array}$ & $\begin{array}{l}15.6 \\
145\end{array}$ & $\begin{array}{l}15.2 \\
15.5\end{array}$ & $\begin{array}{l}14.9 \\
11.9\end{array}$ & $\begin{array}{l}0.0 \\
0.0\end{array}$ & $\begin{array}{l}15.1 \\
150\end{array}$ & $\begin{array}{l}0.0 \\
0.0\end{array}$ & $\begin{array}{l}0.0 \\
0.0\end{array}$ & $\begin{array}{l}15.1 \\
15.1\end{array}$ & $\begin{array}{l}0.0 \\
0.0\end{array}$ & $\begin{array}{l}15.0 \\
14.9\end{array}$ & 0.0 & $\begin{array}{l}0.0 \\
0.0\end{array}$ & $\begin{array}{l}0.0 \\
0.0\end{array}$ & $\begin{array}{l}0.0 \\
0.0\end{array}$ & $\begin{array}{l}0.0 \\
0.0\end{array}$ & 0.0 & $\begin{array}{l}0.0 \\
0.0\end{array}$ & $\begin{array}{l}0.0 \\
0.0\end{array}$ & 0.0 & 0.0 \\
\hline $\begin{array}{l}212121056-30 \\
2121056: 35\end{array}$ & & $\begin{array}{l}1599.51 \\
159.51 \\
\end{array}$ & $\begin{array}{l}103.40 \\
103.40\end{array}$ & $\begin{array}{l}0.0 \\
0.0\end{array}$ & $\begin{array}{l}0.0 \\
0.0\end{array}$ & $\begin{array}{l}\frac{15.5}{15.8} \\
\end{array}$ & $\begin{array}{l}14.8 \\
15.3\end{array}$ & $\begin{array}{l}15.3 \\
15.6\end{array}$ & $\begin{array}{l}\frac{15.0}{15.1} \\
\end{array}$ & $\begin{array}{l}14.5 \\
15.6\end{array}$ & $\begin{array}{l}\frac{15.5}{14.7} \\
\end{array}$ & $\begin{array}{l}14.9 \\
15.0\end{array}$ & $\begin{array}{l}0.0 \\
0.0\end{array}$ & $\begin{array}{l}\frac{15.0}{15.3} \\
1.3\end{array}$ & $\begin{array}{l}0.0 \\
0.0\end{array}$ & $\begin{array}{l}0.0 \\
0.0\end{array}$ & $\begin{array}{l}15.1 \\
15.2 \\
\end{array}$ & $\begin{array}{l}.0 \\
0.0\end{array}$ & $\begin{array}{l}14.9 \\
15.5 \\
\end{array}$ & $\begin{array}{l}0.0 \\
0.0 \\
\end{array}$ & $\begin{array}{l}.0 .0 \\
0.0\end{array}$ & $\begin{array}{l}0.0 \\
0.0\end{array}$ & $\begin{array}{l}0.0 \\
0.0\end{array}$ & $\begin{array}{l}0.0 \\
0.0 \\
\end{array}$ & $\begin{array}{l}0.0 \\
0.0\end{array}$ & & $\begin{array}{l}0.0 \\
0.0 \\
\end{array}$ & $\begin{array}{l}0.0 \\
0.0 \\
\end{array}$ & $\begin{array}{l}0.0 \\
0.0 \\
\end{array}$ \\
\hline |22105 6:40 & 262.91 & 159.45 & 103.46 & 0.0 & 0.0 & 14.7 & 15.0 & 15.0 & 14.7 & 14.9 & 15.8 & 15.0 & 0.0 & 14.6 & 0.0 & 0.0 & $\begin{array}{ll}15.2 \\
\end{array}$ & 0.0 & 15.0 & 0.0 & 0.0 & 0.0 & 0.0 & 0.0 & 0.0 & 0.0 & 0.0 & 0.0 & $\begin{array}{l}0.0 \\
0.0\end{array}$ \\
\hline 2/22105 6:45 & 262.91 & 159.31 & 103.60 & 0.0 & 0.0 & 13.8 & $14.6 \mathrm{C}$ & 14.5 & 14.6 & 15.1 & 13.9 & 14.9 & 0.0 & 14.7. & 0.0 & 0.0 & 14.0 & 0.0 & 14.5 & 0.0 & 0.0 & 0.0 & 0.0 & 0.0 & 0.0 & 0.0 & 0.0 & 0.0 & 0.0 \\
\hline $\begin{array}{l}2 / 2210106: 50 \\
2050\end{array}$ & 262.91 & $\begin{array}{l}1559.31 \\
05030\end{array}$ & $\begin{array}{l}103.60 \\
0.61\end{array}$ & & 0.0 & 13.8 & 14.6 & 14.5 & 14.7 & 14.5 & 15.0 & 15.0 & 0.0 & 14.7 & 0.0 & 0.0 & 13.9 & 0.0 & 14.2 & 0.0 & 0.0 & 0.0 & 0.0 & 0.0 & 0.0 & 0.0 & 0.0 & 0.0 & 0.0 \\
\hline & $\frac{263.01}{263.11}$ & $\begin{array}{r}159.20 \\
158.98 \\
\end{array}$ & $\begin{array}{l}103.81 \\
104.12\end{array}$ & 0.0 & 0.0 & $\frac{14.1}{120}$ & $\frac{14.5}{124}$ & $\frac{14.2}{122}$ & $\begin{array}{l}13.4 \\
12.5 \\
\end{array}$ & $\begin{array}{l}14.0 \\
132\end{array}$ & $\begin{array}{l}13.6 \\
120\end{array}$ & $\frac{13.4}{12.6}$ & $\begin{array}{l}0.0 \\
0.0\end{array}$ & $\frac{14.3}{124}$ & $\frac{0.0}{0.0}$ & $\begin{array}{l}0.0 \\
0.0\end{array}$ & $\frac{14.0}{12.1}$ & $\begin{array}{l}0.0 \\
0.0\end{array}$ & $\frac{14.1}{12.3}$ & $\begin{array}{l}0.0 \\
0.0\end{array}$ & $\frac{0.0}{0.0}$ & $\begin{array}{l}0.0 \\
0.0\end{array}$ & $\begin{array}{l}0.0 \\
0.0\end{array}$ & $\begin{array}{l}0.0 \\
0.0\end{array}$ & $\frac{0.0}{0.0}$ & $\frac{0.0}{0.0}$ & 0.0 & $\begin{array}{l}0.0 \\
0.0\end{array}$ & $\begin{array}{c}0.0 \\
0.0\end{array}$ \\
\hline $21221057: 05$ & $\frac{203.11}{263.11}$ & $\begin{array}{l}105.90 \\
158.76\end{array}$ & $\frac{104.14}{104.34}$ & 0.0 & 0.0 & $\begin{array}{l}12.0 \\
11.8\end{array}$ & $\begin{array}{l}\frac{1.4}{12.1} \\
1.1\end{array}$ & $\begin{array}{l}\frac{12 .}{11.7} \\
1.7\end{array}$ & $\begin{array}{l}\frac{12.5}{11.7} \\
\end{array}$ & 12.4 & $\begin{array}{l}12.0 \\
11.7\end{array}$ & $\begin{array}{l}11.0 \\
11.7\end{array}$ & 0.0 & $\frac{1.4}{12.1}$ & 0.0 & 0.0 & $\frac{12.1}{11.9}$ & 0.0 & $\begin{array}{l}12.5 \\
11.9\end{array}$ & 0.0 & 0.0 & 0.0 & 0.0 & 0.0 & 0.0 & 0.0 & 0.0 & 0.0 & 0.0 \\
\hline 7:10 & 263.21 & 158.69 & 104.52 & 0.0 & 0.0 & 11.8 & 11.6 & 12.0 & 11.9 & 12.6 & 11.8 & 11.7 & 0.0 & 11.9 & 0.0 & 0.0 & \begin{tabular}{|l|l|}
11.8 \\
\end{tabular} & 0.0 & 11.8 & 0.0 & 0.0 & 0.0 & 0.0 & 0.0 & 0.0 & 0.0 & 0.0 & 0.0 & 0.0 \\
\hline & & & 104.52 & 0.0 & 0.0 & 11.8 & 11.6 & 11.7 & 11.8 & 11.8 & 11.8 & 11.7 & 0.0 & 11.8 & 0.0 & 0.0 & 11.9 & 0.0 & 11.7 & 0.0 & 0.0 & 0.0 & 0.0 & 0.0 & 0.0 & 0.0 & 0.0 & 0.0 & 0.0 \\
\hline $2 / 2221057: 20$ & 263.31 & 158.27 & $\frac{105.04}{10.04}$ & 0.0 & 0.0 & 11.7 & $\frac{11.7}{12 .}$ & $\frac{11.6}{12.5}$ & 5.6 & 0.0 & $\frac{11.7}{12.7}$ & 11.7 & 0.0 & $\begin{array}{lll}11.8 \\
1.7\end{array}$ & 0.0 & 0.0 & $\begin{array}{l}11.9 \\
112 .\end{array}$ & 0.0 & $\frac{11.7}{120}$ & 0.0 & 0.0 & 0.0 & 0.0 & & 0.0 & 0.0 & 0.0 & 0.0 & 0.0 \\
\hline $\begin{array}{l}21221057: 25 \\
201212057\end{array}$ & $\begin{array}{l}263.21 \\
263321\end{array}$ & $\begin{array}{l}1585.17 \\
15282\end{array}$ & $\begin{array}{l}1055.04 \\
10393\end{array}$ & 0.0 & $\begin{array}{l}0.0 \\
00 \\
0.0\end{array}$ & 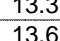 & $\begin{array}{l}12.2 \\
134\end{array}$ & $\begin{array}{l}12.5 \\
137\end{array}$ & $\begin{array}{l}0.0 \\
0.0\end{array}$ & $\begin{array}{l}0.0 \\
0.0\end{array}$ & $\begin{array}{l}13.1 \\
13.5\end{array}$ & $\begin{array}{l}13.6 \\
13.7\end{array}$ & $\begin{array}{l}0.0 \\
0.0\end{array}$ & 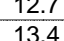 & 0.0 & $\begin{array}{l}.0 .0 \\
0.0\end{array}$ & $\begin{array}{l}12.8 \\
130\end{array}$ & $\begin{array}{l}.0 .0 \\
0.0\end{array}$ & $\begin{array}{l}13.8 \\
134\end{array}$ & $\begin{array}{l}0.0 \\
0.0\end{array}$ & $\begin{array}{l}.0 .0 \\
0.0\end{array}$ & 0 & $\begin{array}{l}0.0 \\
0.0\end{array}$ & $\begin{array}{l}0.0 \\
0.0\end{array}$ & $\begin{array}{l}0.0 \\
0.0\end{array}$ & $\begin{array}{l}0.0 \\
0.0\end{array}$ & $\begin{array}{l}0.0 \\
0.0\end{array}$ & $\begin{array}{l}0.0 \\
0.0\end{array}$ & 0.0 \\
\hline $2 / 221057: 35$ & 2663.21 & $\begin{array}{l}158.27 \\
15\end{array}$ & & 0.0 & 0.0 & 13.5 & 13.5 & 13.5 & 0.0 & 0.0 & 13.1 & 13.7 & 0.0 & 13.4 & 0.0 & 0.0 & 13.0 & 0.0 & 13.4 & 0.0 & 0.0 & 0.0 & 0.0 & 0.0 & 0.0 & 0.0 & 0.0 & 0.0 & 0.0 \\
\hline 205 7:40 & 263.21 & 158.48 & 104.73 & 0.0 & 0.0 & 13.1 & 13.0 & 13.0 & 0.0 & 0.0 & 12.8 & 13.1 & 0.0 & 13.4 & 0.0 & 0.0 & 13.1 & 0.0 & 13.3 & 0.0 & 0.0 & 0.0 & 0.0 & 0.0 & 0.0 & 0.0 & 0.0 & 0.0 & 0.0 \\
\hline & 263.21 & & & 0.0 & 0.0 & 13.1 .1 & 12.9 & 12.9 & 0.0 & 0.0 & 12.7 & 13.0 & 0.0 & 12.4 & 0.0 & 0.0 & 13.1 & 0.0 & 12.9 & 0.0 & 0.0 & 0.0 & 0.0 & 0.0 & 0.0 & 0.0 & 0.0 & 0.0 & 0.0 \\
\hline 7:50 & $\begin{array}{r}263.21 \\
252021\end{array}$ & $\begin{array}{l}159.03 \\
15010\end{array}$ & $\begin{array}{l}104.18 \\
101111\end{array}$ & 0.0 & 0.0 & 13.1 & $\frac{12.8}{120}$ & $\frac{12.9}{122}$ & 0.0 & 0.0 & 12.8 & $\begin{array}{l}13.0 \\
130\end{array}$ & 0.0 & 12.4 & 0.0 & 0.0 & $\begin{array}{l}13.0 \\
130\end{array}$ & 0.0 & 12.6 & 0.0 & 0.0 & 0.0 & 0.0 & 0.0 & 0.0 & 0.0 & 0.0 & 0.0 & $0.0]$ \\
\hline$\frac{2 / 22 / 1057: 55}{2122058}$ & $\begin{array}{l}2636.21 \\
263.21\end{array}$ & $\begin{array}{l}155.10 \\
158.89 \\
\end{array}$ & $\begin{array}{l}104.11 \\
104.32\end{array}$ & 0.0 & $\frac{0.0}{0.0}$ & $\frac{13.2}{132}$ & $\frac{12.8}{130}$ & $\begin{array}{l}13.2 \\
13.5\end{array}$ & $\begin{array}{l}0.0 \\
0.0\end{array}$ & 0.0 & $\frac{13.1}{12.5}$ & $\begin{array}{l}13.0 \\
130\end{array}$ & $\begin{array}{l}0.0 \\
0.0\end{array}$ & $\frac{13.0}{132}$ & $\frac{0.0}{0.0}$ & $\frac{0.0}{0.0}$ & $\frac{13.0}{131}$ & 0.0 & $\frac{12.6}{11.9}$ & $\begin{array}{l}0.0 \\
0.0\end{array}$ & $\frac{0.0}{0.0}$ & $\frac{0.0}{0.0}$ & $\frac{0.0}{0.0}$ & $\begin{array}{l}0.0 \\
0.0\end{array}$ & 0.0 & $\frac{0.0}{0.0}$ & 0.0 & $\begin{array}{l}0.0 \\
0.0\end{array}$ & 0.00 \\
\hline $2 / 221058: 05$ & 263.21 & 158.89 & 104.32 & 0.0 & 0.0 & 13.7 & 13.1 & 13.4 & 0.0 & 0.0 & 13.8 & $\begin{array}{l}13.0 \\
13.0\end{array}$ & 0.0 & $\begin{array}{l}13.6 \\
13.7\end{array}$ & 0.0 & 0.0 & $\begin{array}{l}13.1 \\
13.4\end{array}$ & 0.0 & 11.9 & 0.0 & 0.0 & $\begin{array}{l}0.0 \\
0.0\end{array}$ & 0.0 & 0.0 & 0.0 & 0.0 & 0.0 & 0.0 & 0.0 \\
\hline 2/22105 8:10 & 263.21 & 159.10 & 104.11 & 0.0 & 0.0 & 13.9 & 13.2 & 13.7 & 0.0 & 0.0 & 13.8 & 13.5 & 0.0 & 13.9 & 0.0 & 0.0 & 13.4 & 0.0 & 11.9 & 0.0 & 0.0 & 0.0 & 0.0 & 0.0 & 0.0 & 0.0 & 0.0 & 0.0 & 0.0 \\
\hline $2 / 221058: 15$ & 263.21 & 159.31 & & 0.0 & 0.0 & 13.9 & 13.4 & 13.8 & 0.0 & 0.0 & 13.8 & 13.5 & 0.0 & 14.0 & 0.0 & 0.0 & 13.7. & 0.0 & 11.9 & 0.0 & 0.0 & 0.0 & 0.0 & 0.0 & 0.0 & 0.0 & 0.0 & 0.0 & 0.0 \\
\hline $\begin{array}{l}2 / 221058: 20 \\
221212058.25\end{array}$ & $\begin{array}{l}263.31 \\
263331\end{array}$ & $\begin{array}{l}159.31 \\
159.31 \\
\end{array}$ & $\begin{array}{l}104.00 \\
104.00\end{array}$ & $\begin{array}{l}0.0 \\
0.0\end{array}$ & $\begin{array}{l}0.0 \\
0.0\end{array}$ & $\begin{array}{l}13.9 \\
13.9\end{array}$ & $\begin{array}{l}13.4 \\
13.2\end{array}$ & $\begin{array}{l}13.8 \\
127 \\
\end{array}$ & $\begin{array}{l}0.0 \\
0.0\end{array}$ & $\begin{array}{l}0.0 \\
0.0\end{array}$ & $\begin{array}{r}13.7 \\
136\end{array}$ & $\begin{array}{l}13.4 \\
13.5\end{array}$ & $\begin{array}{l}0.0 \\
0.0\end{array}$ & $\begin{array}{l}13.3 \\
126\end{array}$ & 0.0 & 0.0 & $\begin{array}{l}12.5 \\
123\end{array}$ & $\begin{array}{l}0.0 \\
0.0\end{array}$ & 12.0 & 0.0 & $\begin{array}{l}0.0 \\
0.0\end{array}$ & $\begin{array}{l}0.0 \\
0.0\end{array}$ & $\begin{array}{l}0.0 \\
0.0\end{array}$ & $\begin{array}{l}0.0 \\
0.0\end{array}$ & $\begin{array}{l}0.0 \\
0.0\end{array}$ & 0.0 & 0.0 & 0.0 & 0.0 \\
\hline $212121058: 30$ & & & & 0.0 & 0.0 & 10.5 & 13.2 & $\begin{array}{l}12.1 \\
126\end{array}$ & 0.0 & 0.0 & 12.8 & 10.5 & 0.0 & $\frac{12.6}{126}$ & 0.0 & 0.0 & $\begin{array}{l}12.3 \\
12.3 \\
\end{array}$ & 0.0 & 11.9 & $\begin{array}{l}0.0 \\
0.0\end{array}$ & 0.0 & 0.0 & 0.0 & 0.0 & 0.0 & 0.0 & 0.0 & 0.0 & 0.0 \\
\hline $2 / 221058: 35$ & 263.21 & 159.25 & 103.96 & 0.0 & 0.0 & $\begin{array}{l}\frac{12.5}{13.5} \\
1.5\end{array}$ & $\begin{array}{l}13.6 \\
13.0\end{array}$ & $\begin{array}{l}12.0 \\
12.8\end{array}$ & 0.0 & 0.0 & 13.9 & 13.5 & 0.0 & 12.7 & 0.0 & 0.0 & 12.5 & 0.0 & 12.0 & 0.0 & 0.0 & 0.0 & 0.0 & 0.0 & 0.0 & 0.0 & 0.0 & 0.0 & 0.0 \\
\hline $2 / 221 / 1$ & 263.21 & 159.25 & & 0.0 & 0.0 & 14.2 & 13.4 & 13.7 & 0.0 & 0.0 & 13.7 & 13.6 & 0.0 & 13.6 & 0.0 & 0.0 & 14.0 & 0.0 & 12.0 & 0.0 & 0.0 & 0.0 & 0.0 & 0.0 & 0.0 & 0.0 & 0.0 & 0.0 & 0.0 \\
\hline 2/221/205 8:45 & 263.21 & 159.31 & 103.90 & 0.0 & 0.0 & 14.2. & 13.6 & 13.8 & 0.0 & 0.0 & 13.7 & 13.7 & 0.0 & 13.7 & 0.0 & 0.0 & 14.1. & 0.0 & 12.0 & 0.0 & 0.0 & 0.0 & 0.0 & 0.0 & 0.0 & 0.0 & 0.0 & 0.0 & 0.0 \\
\hline $\begin{array}{l}2121210585: 50 \\
212105855\end{array}$ & $\begin{array}{l}2636.21 \\
263.31\end{array}$ & $\frac{155.41}{159.62}$ & $\begin{array}{l}103.80 \\
10369\end{array}$ & 0.0 & $\frac{0.0}{0.0}$ & $\frac{12.6}{143}$ & $\begin{array}{l}13.6 \\
137\end{array}$ & $\frac{13.1}{138}$ & $\begin{array}{l}0.0 \\
0.0\end{array}$ & 0.0 & $\begin{array}{l}13.6 \\
13.7\end{array}$ & $\frac{13.7}{13.7}$ & $\begin{array}{l}0.0 \\
0.0\end{array}$ & $\begin{array}{l}13.7 \\
137 \\
\end{array}$ & $\begin{array}{l}0.0 \\
0.0\end{array}$ & $\frac{0.0}{0.0}$ & $\frac{12.2}{138}$ & $\frac{0.0}{0.0}$ & $\frac{11.9}{11.9}$ & $\begin{array}{l}0.0 \\
0.0\end{array}$ & $\begin{array}{l}0.0 \\
0.0\end{array}$ & $\begin{array}{l}0.0 \\
0.0\end{array}$ & $\begin{array}{l}0.0 \\
0.0\end{array}$ & $\begin{array}{l}0.0 \\
0.0\end{array}$ & $\begin{array}{l}0.0 \\
0.0\end{array}$ & $\begin{array}{l}0.0 \\
0.0\end{array}$ & $\begin{array}{l}0.0 \\
0.0\end{array}$ & $\begin{array}{l}0.0 \\
0.0\end{array}$ & 0.00 \\
\hline 212 & .1 & 15 & & 0.0 & - 0 & $\begin{array}{l}14.3 \\
13.1\end{array}$ & $\begin{array}{l}13.1 \\
13.7\end{array}$ & 138 & $\begin{array}{l}0.0 \\
0.0\end{array}$ & 0.0 & 13.7. & 13.7 & $\begin{array}{l}0.0 \\
0.0\end{array}$ & $\begin{array}{l}131 \\
137\end{array}$ & 0.0 & 0.0 & $\begin{array}{l}13.8 \\
140\end{array}$ & 0.0 & $\frac{11.99}{11.9}$ & $\begin{array}{l}0.0 \\
0.0\end{array}$ & 0.0 & 0.0 & 0.0 & 0.0 & 0.0 & 0.0 & 0.0 & 0.0 & 0.0 \\
\hline $2 / 221059: 05$ & 263.31 & 159.41 & 103.90 & 0.0 & 0.0 & 14.5 & 13.8 & 14.0 & 0.0 & 0.0 & 13.7 & 13.8 & 0.0 & 13.8 & 0.0 & 0.0 & 14.1 & 0.0 & 12.0 & 0.0 & 0.0 & 0.0 & 0.0 & 0.0 & 0.0 & 0.0 & 0.0 & 0.0 & 0.0 \\
\hline 2/22105 9:10 & $\begin{array}{r}263.41 \\
262.11\end{array}$ & $\begin{array}{l}159.41 \\
1521 \\
21\end{array}$ & 104.00 & 0.0 & 0.0 & $\begin{array}{l}14.0 \\
1.0\end{array}$ & $\begin{array}{l}13.7 \\
130\end{array}$ & $\begin{array}{l}13.9 \\
120\end{array}$ & 0.0 & 0.0 & 14.2 & $\begin{array}{l}13.8 \\
137\end{array}$ & 0.0 & 13.8 & 0.0 & 0.0 & 14.2 & 0.0 & 12.0 & 0.0 & 0.0 & 0.0 & 0.0 & 0.0 & 0.0 & 0.0 & 0.0 & 0.0 & 0.0 \\
\hline $\begin{array}{l}59: 15 \\
5 \\
5\end{array}$ & & & & $\begin{array}{l}0.0 \\
0.0\end{array}$ & $\begin{array}{l}0.0 \\
0.0\end{array}$ & $\begin{array}{l}14.0 \\
136 \\
13 .\end{array}$ & $\begin{array}{l}13.9 \\
139\end{array}$ & 13.9 & $\begin{array}{l}0.0 \\
0.0\end{array}$ & $\begin{array}{l}0.0 \\
0.0\end{array}$ & 14.2 & $\begin{array}{l}13.7 \\
132\end{array}$ & 0.0 & 14.42 & 0.0 & $\begin{array}{l}0.0 \\
0.0\end{array}$ & (14.2. & 0 & 12.0 & 0.0 & $\begin{array}{l}0.0 \\
0.0\end{array}$ & 0.0 & 0.0 & 0.0 & 0.0 & 0.0 & 0.0 & & $\begin{array}{ll}0.00 \\
0.0\end{array}$ \\
\hline & $\begin{array}{l}253.44 \\
2651\end{array}$ & 154 & & 0.0 & 0.0 & 13.6 & 13.9 & 13.9 & 0. & 0.0 & 14.2 & 13.8 & 0 & 14.2 & & 0.0 & 14.1 & 0.0 & 11.9 & 0 & 0.0 & 0.0 & 0.0 & 0 & 0.0 & 0.0 & 0.0 & 0.0 & $0.0]$ \\
\hline $2 / 221059: 30$ & 2063.51 & $\begin{array}{l}155.91 \\
159.16\end{array}$ & $\begin{array}{l}104.20 \\
104.35\end{array}$ & $\begin{array}{l}0.0 \\
0.0\end{array}$ & 0.0 & $\begin{array}{l}\frac{14.3}{13.1} \\
13\end{array}$ & $\begin{array}{l}13.4 \\
13.4 \\
\end{array}$ & $\begin{array}{l}13.9 \\
13.9 \\
\end{array}$ & 0.0 & 0.0 & 12.7 & $\begin{array}{l}13.8 \\
138\end{array}$ & $\begin{array}{l}0.0 \\
0.0\end{array}$ & $\begin{array}{l}14.2 \\
141\end{array}$ & 0.0 & 0.0 & $\begin{array}{l}13.1 \\
13.9\end{array}$ & 0.0 & $\frac{12.00}{11.9}$ & 0.00 & $\begin{array}{l}0.0 \\
0.0\end{array}$ & $\begin{array}{l}0.0 \\
0.0\end{array}$ & 0 & 0.0 & 0.0 & 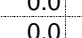 & 0 & 0 & $\begin{array}{l}0.0 \\
0.0 \\
0.0\end{array}$ \\
\hline $2 / 21 / 1059: 35$ & 263.51 & 15 & 10 & 0.0 & 0.0 & 13.8 & 13.3 & 13.4 & 0.0 & 0.0 & 13.2 & 13.8 & 0.0 & 14.1 & 0 & 0.0 & $\begin{array}{ll}14.1 \\
\end{array}$ & 0.0 & 12.0 & 0.0 & 0.0 & 0.0 & 0.0 & 0.0 & 0.0 & 0.0 & 0.0 & 0.0 & 0.0 \\
\hline $\begin{array}{l}59: 40 \\
5 \text { 59:45 }\end{array}$ & $\begin{array}{r}263.51 \\
2361\end{array}$ & $\begin{array}{l}159.10 \\
1500\end{array}$ & 104.41 & 0.0 & 0.0 & 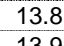 & 13.4 & 12.8 & 0.0 & 0.0 & $\begin{array}{l}13.3 \\
12.3\end{array}$ & $\begin{array}{l}13.8 \\
125\end{array}$ & 0.0 & $\begin{array}{l}14.1 \\
126\end{array}$ & 0.0 & 0.0 & 13.3 & 0.0 & 12.0 & 0.0 & 0.0 & 0.0 & 0.0 & 0.0 & 0.0 & 0.0 & 0.0 & 0.0 & 0.0 \\
\hline $5 \frac{5: 45}{50.50}$ & & & & & & 13.9 & $\begin{array}{ll}13.0 \\
13.0\end{array}$ & 12.8 & & & 13.3 & 13.5 & & 13.6 & 0.0 & 0.0 & 12.99 & & 12 & 0.0 & & & & 0.0 & & & & 0.0 & $0.0]$ \\
\hline & $\begin{array}{l}2536.01 \\
26.61\end{array}$ & $\begin{array}{l}159 \\
159\end{array}$ & & . & 0 & $\begin{array}{l}12.6 \\
130\end{array}$ & $\begin{array}{l}13.1 \\
123\end{array}$ & $\begin{array}{l}\frac{12.8}{12.5} \\
\end{array}$ & 0. & 0.0 & 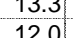 & $\begin{array}{l}13.4 \\
11.6\end{array}$ & 0.0 & $\begin{array}{ll}12.3 \\
123\end{array}$ & 0.0 & $\begin{array}{l}0.0 \\
0.0\end{array}$ & $\begin{array}{l}12.8 \\
129\end{array}$ & 0.0 & 11.99 & 0.0 & 0.0 & 0.0 & 0.0 & 0.0 & 0.0 & 然. & 0 & 0.0 & 0.0 \\
\hline & 263.51 & 155 & 10 & 0.0 & 0.0 & 13.2 & 12.3 & $\begin{array}{l}1.2 .5 \\
12.5\end{array}$ & 0.0 & 0.0 & 12.7 & 13.2 & 0.0 & 13.2 & 0.0 & $\begin{array}{l}.0 \\
0.0\end{array}$ & $\begin{array}{l}12.9 \\
12.9\end{array}$ & 0.0 & 11.9 & 0.0 & 0.0 & 0.0 & 0.0 & 0.0 & 0.0 & 0.0 & 0.0 & 0.0 & 0.0 \\
\hline $2 / 2210510.012$ & 263.51 & 159.41 & 10 & 0.0 & 0.0 & 13.1 & 13.0 & 13.7 & 0.0 & 0.0 & 13.7 & 13.1 & 0.0 & 13.4 & 0.0 & 0.0 & 13.0 & 0.0 & 11.9 & 0.0 & 0.0 & 0.0 & 0.0 & 0.0 & 0.0 & 0.0 & 0.0 & 0.0 & 0.0 \\
\hline & $\begin{array}{r}263.58 \\
23651\end{array}$ & $\begin{array}{r}159.41 \\
150.11\end{array}$ & & 0.0 & 0.0 & $\begin{array}{l}13.7 \\
138\end{array}$ & $\begin{array}{l}13.1 \\
131\end{array}$ & $\begin{array}{l}13.3 \\
132\end{array}$ & 0.0 & 0.0 & 13.8 & $\begin{array}{l}13.4 \\
1.0\end{array}$ & 0.0 & 13.5 & 0.0 & 0.0 & 14.0 & 0.0 & 12.0 & 0.0 & 0.0 & 0.0 & 0.0 & 0.0 & 0.0 & 0.0 & 0.0 & 0.0 & 0.0 \\
\hline & $\begin{array}{l}2536.61 \\
26.61\end{array}$ & $\begin{array}{l}15954.41 \\
15951\end{array}$ & & & 0.0 & $\frac{13.8}{134}$ & $\frac{13.1}{131}$ & & & & 13.8 & $\begin{array}{l}14.0 \\
10.7\end{array}$ & & 1 & 0.0 & 0.0 & $\begin{array}{ll}14.0 \\
140\end{array}$ & & 11. & 0.6 & & 0 & 0.0 & 0.0 & 0.0 & 0.0 & 0.0 & & 0.0 \\
\hline$\frac{212103010.25}{212205}$ & $\begin{array}{l}20350.01 \\
2361\end{array}$ & $\begin{array}{l}159.51 \\
15.51\end{array}$ & & 0.0 & : & 13.4 & 1.1 & 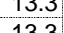 & 0.6 & 0.0 & 13.9 & 10.1 & 0.0 & 13.4 & & 0.0 & 14.0 & 0.0 & 11.9 & 0.6 & 0.0 & & 0.0 & 0.0 & 0.0 & 0.0 & 0.0 & 0.0 & 0.0 \\
\hline & 263.61 & 15 & 10 & 0.0 & 0 & 13.6 & $\begin{array}{l}1.1 \\
12.7 \\
\end{array}$ & 13.3 & 0. & 0.0 & 12.4 & 12.8 & 0.0 & 13.5 & & 0.0 & $\mid 12.7$ & 0.0 & 12.0 & 0.6 & 0.0 & 0.0 & 0 & 0 & 0.0 & 0.0 & 0.0 & 0.0 & 然. \\
\hline 35 & 263.51 & 15 & 10 & 0.0 & 0.0 & 12.5 & 12.6 & 13.3 & 0.6 & 0.0 & 12.1 & & 0.0 & 13.4 & 0. & 0.0 & 12.8 & 0.0 & 11.9 & 0.0 & 0.0 & 0.0 & 0 & 0.0 & 0.0 & 0.0 & 0.0 & 0.0 & 0.0 \\
\hline & 263.511 & & & & & & 12 & 13 & $0 . c$ & & 12.19 & $\frac{12}{12}$ & 0.0 & & & 0.0 & 12.7 & & & 0.0 & 0.0 & & & & 0.0 & 0 & 0.0 & 0.0 & 0 \\
\hline : & $\begin{array}{l}2536.51 \\
2651\end{array}$ & $\begin{array}{l}159 \\
150\end{array}$ & & 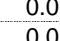 & 0. & 12 & $\begin{array}{l}12.6 \\
127\end{array}$ & 13 & 0 & 0.0 & $\begin{array}{ll}12.8 \\
129\end{array}$ & 12 & 0 & $\begin{array}{l}12.3 \\
123\end{array}$ & & 0.0 & $\begin{array}{ll}12.6 \\
126\end{array}$ & 0 & 12. & 0 & 0.0 & 0.0 & 0.0 & 0.0 & 0.0 & 然 & 0.0 & 0.0 & 0.0 \\
\hline & $\begin{array}{l}2050.51 \\
25.11\end{array}$ & 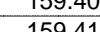 & & 0.0 & 0 & $\frac{11}{13}$ & 12 & 12.1 & 0 & 0.0 & 14 & 12 & 0 & $\begin{array}{l}12.5 \\
122\end{array}$ & & 0.0 & 12.0 & 0 & 114 & 0 & 0.0 & & & & & 0.0 & 0 & & 0.0 \\
\hline $2 / 2$ & 263.51 & 159 & 10 & 0.0 & 0.0 & 12 & 12.7 & 13.0 & 0 & 0.0 & 12 & 12. & 0 & 12 & 0.0 & 0.0 & 12.6 & 0.0 & 11. & 0. & 0.0 & 0.0 & 0.0 & 0.0 & 0.0 & 0.0 & 0.0 & 0.0 & 0.0 \\
\hline & & & & 0.0 & 0.6 & 13.3 & 12 & 13 & 0. & 0.0 & 12 & 12 & 0 & 1 & & 0.0 & 12.7. & 0.0 & 11 & 0.6 & 0.0 & 0.0 & 0.0 & & 0. & 0.0 & & & 0.0 \\
\hline & & & & & & & & & & & & & & & & & & & & & & & & & & & & & 0.0 \\
\hline & 263.41 & 15 & & o & 0 & 13 & $\begin{array}{l}12.8 \\
1.27\end{array}$ & 13. & 0 & 0.0 & $\begin{array}{l}12.9 \\
120\end{array}$ & $\begin{array}{l}12 . \\
12\end{array}$ & 0 & & 0 & 0.0 & $\begin{array}{ll}12.7 \\
1.7\end{array}$ & 0.0 & 11.9 & 0. & 0.0 & $\begin{array}{l}0.0 \\
0\end{array}$ & 0.0 & 0 & 0.0 & o 0.0 & 0.0 & 0.0 & 0.0 \\
\hline & $\begin{array}{l}2533.41 \\
23641\end{array}$ & & & 0.0 & 0. & 13 & 12 & $\begin{array}{l}1.3 \\
13\end{array}$ & 0. & 0.0 & $\frac{1}{12}$ & 12 & 0 & 12 & & 0.0 & 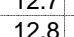 & 0 & & & 0.0 & 0.0 & & & 0.0 & . & 0 & 0.0 & 0.00 \\
\hline$\frac{2122}{2 / 22}$ & $\begin{array}{l}2050.41 \\
263.41\end{array}$ & $\begin{array}{l}155.41 \\
159.41\end{array}$ & 104.00 & 0.0 & 0. & 13 & 12.7 & 13.0 & 0. & 0.0 & 12 & 12.6 & 0.0 & 12.3 & 0.0 & 0.0 & $\begin{array}{l}12.0 \\
12.7\end{array}$ & 0.0 & 1 & 0 & 0.0 & 0.0 & .0 & 0.0 & 0.0 & 0.0 & 0.0 & 0.0 & 0.0 \\
\hline & 263.41 & & & 0.0 & 0 & 12 & 11.3 & 12.6 & 0 & 0.0 & 12 & 12.6 & 0.0 & & & 0 & 12.0 & & 1 & & 0.0 & 0.0 & & 0.0 & 0.0 & .0 & 0 & 0.0 & 0 \\
\hline$: 40$ & 1 & 15 & & & 0.0 & & 0.0 & 13 & 0.0 & 0.0 & 13 & 14.0 & 0 & & & 0.6 & 14.0 & & $\begin{array}{l}9 \\
\end{array}$ & & & & & 0 & 0.0 & 0.0 & & 0.0 & 0.0 \\
\hline $\begin{array}{ll}1: 45 \\
: 150\end{array}$ & 263.41 & 159.47 & 100 & 0.0 & 0 & 1 & 0.0 & 14. & 0 & 0.0 & 13.7 & 14 & 0 & & 0. & 0. & 12 & 0.0 & & & 0.0 & & & 0.0 & 0.0 & & & 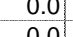 & .0| \\
\hline 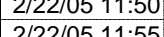 & $\begin{array}{l}2533.41 \\
26.41\end{array}$ & 15 & & 0. & 0.0 & 14 & 然 & 14 & 0 & 0.0 & 14.4 & $\begin{array}{l}14.2 \\
144\end{array}$ & 0 & $\begin{array}{l}14.8 \\
1.7\end{array}$ & & 0.0 & 12 & 0.0 & 12.00 & - & 0.6 & 0.0 & & 0.0 & 0.0 & 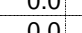 & 0 & 0.0 & 0.0 \\
\hline $2: 00$ & $\frac{105.41}{263.41}$ & 159.18 & 104.23 & 0.0 & 0.0 & 14 & 0.0 & 14.4 & 0. & 0.0 & $\begin{array}{l}14.0 \\
14.7\end{array}$ & $\begin{array}{l}14.0 \\
14.3\end{array}$ & 0.0 & 14.5 & 0.0 & 0.0 & 14.8 & 0.0 & & .0 & 0.0 & 0.0 & 0.0 & .0 & 0.0 & 0.0 & 0.0 & 0.0 & - \\
\hline 512:05 & 263.41 & 155 & 104.21 & 0.0 & 0.0 & 1 & 0.0 & 14.3 & 0. & & 14 & 14.4 & 0.0 & 14.3 & 0. & 0.0 & 14.4 & 0.0 & 11.9 & .0 & 0.0 & 0.0 & 0.0 & 0.0 & 0.0 & 0.0 & 0.0 & 0.0 & \\
\hline
\end{tabular}




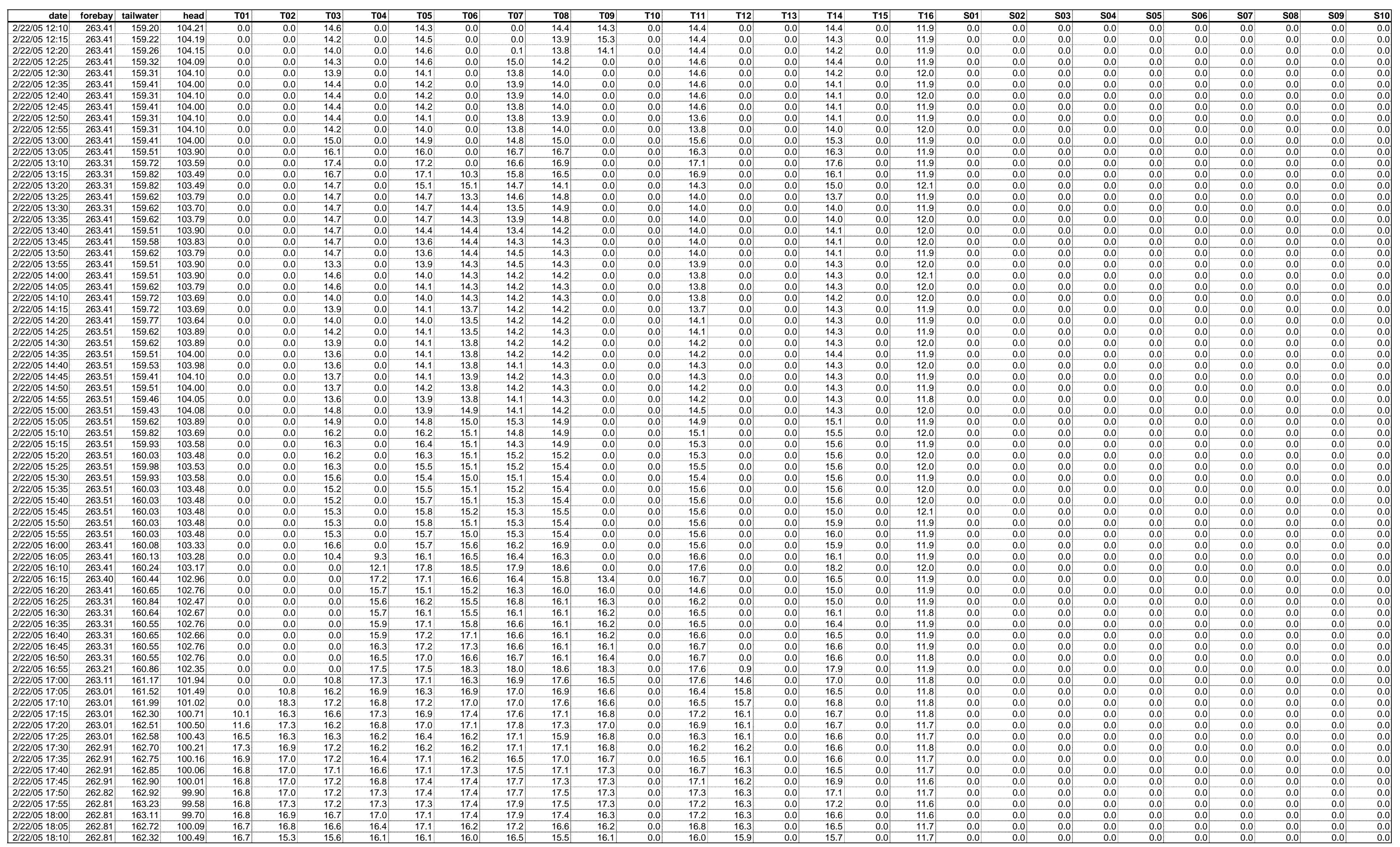




\begin{tabular}{|c|c|c|c|c|c|c|c|c|c|c|c|c|c|c|c|c|c|c|c|c|c|c|c|c|c|c|c|c|c|}
\hline date & fore & & head & T01 & T02 & T03 & T04 & T05 & 106 & I0r & T08 & T09 & 110 & $1 \pm$ & T12 & 113 & T14 & 115 & 116 & 300 & 502 & S03 & 504 & S05 & 506 & S07 & 508 & S09 & $\mathbf{S 1 0}$ \\
\hline 18:15 & .91 & 162.30 & 100.61 & 15.6 & 15.2. & 15.7. & 15.6 & 15.6 & 15.8 & 15.8 & 15.3 & 16.2 & 0.0 & 15.2. & 16.0 & 0.0 & 15.7 & 0.0 & 11.7 & 0.0 & 0.0 & 0.0 & 0.0 & 0.0 & 0.0 & 0.0 & 0.0 & 0.0 & 0.0 \\
\hline 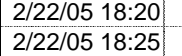 & $\begin{array}{l}262.91 \\
262.91\end{array}$ & $\frac{162.20}{162.10}$ & $\begin{array}{l}10.71 \\
100.81\end{array}$ & $\frac{15.5}{15.5}$ & $\begin{array}{l}15.1 \\
15.2\end{array}$ & 15.0 & $\frac{15.6}{15.6}$ & $\begin{array}{l}15.5 \\
16.0 \\
\end{array}$ & $\frac{15.7}{15.4}$ & 15.9 & $\begin{array}{l}15.3 \\
16.0\end{array}$ & $\frac{16.1}{16.1}$ & $\begin{array}{l}0.0 \\
0.0\end{array}$ & 15.1.9. & $\begin{array}{l}\frac{16.3}{16.0} \\
16\end{array}$ & $\begin{array}{l}0.0 \\
0.0\end{array}$ & $\begin{array}{l}\frac{15.7}{15.7} \\
\end{array}$ & $\begin{array}{l}0.0 \\
0.0\end{array}$ & $\begin{array}{l}11.7 \\
11.8\end{array}$ & $\begin{array}{l}0.0 \\
0.0\end{array}$ & $\begin{array}{l}0.0 \\
0.0\end{array}$ & $\begin{array}{l}0.0 \\
0.0\end{array}$ & $\begin{array}{l}0.0 \\
0.0\end{array}$ & $\begin{array}{l}0.0 \\
0.0\end{array}$ & $\begin{array}{l}0.0 \\
0.0\end{array}$ & $\begin{array}{l}0.0 \\
0.0\end{array}$ & $\begin{array}{l}0.0 \\
0.0\end{array}$ & 0.0 & $\begin{array}{l}0.0 \\
0.0\end{array}$ \\
\hline $20518: 30$ & $\begin{array}{l}202.81 \\
262.81\end{array}$ & 162.25 & 100.56 & $\begin{array}{l}13.5 \\
15.6\end{array}$ & $\frac{13.2}{15.4}$ & 16.5 & $\begin{array}{l}15.6 \\
15.6\end{array}$ & $\begin{array}{l}10.0 \\
16.0\end{array}$ & $\begin{array}{l}1.4 \\
16.9\end{array}$ & 16.2 & $\begin{array}{l}10.0 \\
16.1\end{array}$ & $\begin{array}{l}10.1 \\
16.2\end{array}$ & 0.0 & 16.1 & $\begin{array}{l}10.0 \\
16.7\end{array}$ & 0.0 & $\begin{array}{l}15.1 \\
15.7\end{array}$ & 0.0 & $\begin{array}{ll}11.6 \\
11.7\end{array}$ & 0.0 & 0.0 & 0.0 & 0.0 & 0.0 & 0.0 & 0.0 & 0.0 & 0.0 & 0.0 \\
\hline 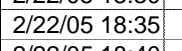 & 262.81 & 162.30 & 100.51 & 15.6 & 15.4 & $\begin{array}{ll}16.4 \\
6.4\end{array}$ & 15.6 & 16.0 & 16.3 & $\begin{array}{l}16.2 \\
6.2 \\
-1\end{array}$ & 16.1 & 16.2 & 0.0 & 16.1 & 16.9 & 0.0 & 15.8 & 0.0 & 11.7 & 0.0 & 0.0 & 0.0 & 0.0 & 0.0 & 0.0 & 0.0 & 0.0 & 0.0 & 0.0 \\
\hline $2 / 22 / 0518: 40$ & 262.91 & 162.30 & 100.61 & 15.5 & 16.7 & 16.4 & 15.7 & 16.0 & 16.3 & 16.2 & 16.0 & 16.2 & 0.0 & 16.0 & 16.5 & 0.0 & 15.7. & 0.0 & 11.7 & 0.0 & 0.0 & 0.0 & 0.0 & 0.0 & 0.0 & 0.0 & 0.0 & 0.0 & \\
\hline$\frac{2 / 2 / 2 / 50518: 45}{2 / 21 / 55}$ & $\frac{262.91}{26291}$ & $\frac{162.22}{162.19}$ & $\begin{array}{l}100.69 \\
100.72\end{array}$ & $\frac{15.5}{15.5}$ & $\frac{16.2}{15.7}$ & $\begin{array}{l}16.3 \\
16.4 \\
16.4\end{array}$ & $\frac{16.2}{16.1}$ & $\frac{16.0}{16.0}$ & $\frac{16.2}{16.2}$ & $\begin{array}{ll}16.1 \\
616.2\end{array}$ & $\frac{16.0}{16.0}$ & $\frac{16.2}{16.2}$ & 0.0 & 16.1. & $\frac{16.6}{16.4}$ & 0.0 & $\frac{15.8}{15.7}$ & $\begin{array}{l}0.0 \\
0.0\end{array}$ & $\frac{11.7}{11.7}$ & 0.0 & 0.0 & 0.0 & 0.0 & 0.0 & 0.0 & 0.0 & 0.0 & 0.0 & $\begin{array}{l}0.0 \\
0.0\end{array}$ \\
\hline \begin{tabular}{|l|l|l|l|l|} 
\\
$2 / 22 / 05$ & $18: 50$ \\
\end{tabular} & $\begin{array}{ll}202.291 \\
262.91\end{array}$ & $\begin{array}{l}\frac{102.19}{162.20} \\
\end{array}$ & $\frac{10 . / 2}{100.71}$ & $\frac{15.5}{15.5}$ & $\frac{15.7}{15.7}$ & $\begin{array}{l}15.4 .4 \\
15.3 \\
\end{array}$ & $\frac{16.1}{16.2}$ & $\begin{array}{ll}1.6 .0 \\
16.0\end{array}$ & $\frac{10.2}{15.0}$ & $\begin{array}{ll}10.2 \\
16.2\end{array}$ & $\frac{10.0}{16.0}$ & $\frac{10.2}{16.2}$ & 0.0 & $\begin{array}{l}10.0 .0 \\
16.0 \\
\end{array}$ & $\frac{10.4}{16.4}$ & 0.0 & $\frac{15.1}{15.8}$ & 0.0 & $\frac{11.1}{11.7}$ & 0.0 & 0.0 & 0.0 & 0.0 & 0.0 & 0.0 & 0.0 & 0.0 & 0.0 & $\begin{array}{l}0.0 \\
0.0\end{array}$ \\
\hline $2 / 22 / 05$ 19:00 & 262.91 & 162.25 & 100.66 & $\begin{array}{l}13.5 \\
15.5\end{array}$ & $\begin{array}{ll}15.3 \\
15.3\end{array}$ & 15.2 & $\begin{array}{l}1.2 .2 \\
16.2\end{array}$ & $\begin{array}{l}15.0 \\
15.9\end{array}$ & $\begin{array}{ll}15.0 \\
15.3\end{array}$ & 10.1 & $\begin{array}{l}10.0 \\
15.7\end{array}$ & $\begin{array}{l}10.4 \\
15.7\end{array}$ & 0.0 & 15.7 & $\begin{array}{l}10.4 \\
16.5\end{array}$ & 0.0 & $\begin{array}{l}1.0 \\
15.5\end{array}$ & 0.0 & $\begin{array}{l}11.1 \\
11.7\end{array}$ & 0.0 & 0.0 & 0.0 & 0.0 & 0.0 & 0.0 & 0.0 & 0.0 & 0.0 & $\begin{array}{l}0.0 \\
0.0\end{array}$ \\
\hline $\begin{array}{l}2 / 2210519: 05 \\
\end{array}$ & 262.91 & 162.19 & 100.72 & 15.1 & 15.0 & $\begin{array}{ll}15.2 \\
5.2 \\
-1\end{array}$ & 15.0 & 15.3 & 15.3 & 15.8 & 14.8 & 15.1 & 0.0 & 15.3. & 16.5 & 0.0 & 15.0 & 0.0 & 11.7 & 0.0 & 0.0 & 0.0 & 0.0 & 0.0 & 0.0 & 0.0 & 0.0 & 0.0 & 0.0 \\
\hline \begin{tabular}{|l|}
$2 / 22 / 0519: 10$ \\
$2 / 2 / 2519 \cdot 15$
\end{tabular} & 262.91 & 162.09 & 100.82 & 14.7 & 14.9 & $\begin{array}{ll}14.7 \\
117.7\end{array}$ & 14.9 & 14.7 & 15.1 & 14.9 & 14.6 & $\begin{array}{ll}14.7 \\
146\end{array}$ & 0.0 & 14.8. & 16.5 & 0.0 & 15.0 & 0.0 & 11.7 & 0.0 & 0.0 & 0.0 & 0.0 & 0.0 & 0.0 & 0.0 & 0.0 & 0.0 & 0.0 \\
\hline \begin{tabular}{|c|}
$2 / 22 / 2 / 519: 15$ \\
$2 / 22 / 5519: 20$
\end{tabular} & 262.91 & 162.17 & & 14.6 & 14.9 & 14.7. & 15.0 & $\begin{array}{l}14.6 \\
1146\end{array}$ & 14.2 & 15.2. & 14.6 & 14.6 & 0.0 & 14.6. & 16.4 & 0.0 & $\frac{15.1}{150}$ & 0.0 & 11.7 & 0.0 & 0.0 & 0.0 & 0.0 & 0.0 & 0.0 & 0.0 & 0.0 & 0.0 & 0.0 \\
\hline$\frac{1240519.20}{2 / 22 / 0519: 25}$ & 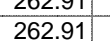 & 年 & 100.18 & $\begin{array}{lll}\frac{14.0}{14.5} & & \end{array}$ & 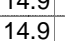 & 14.6 & $\begin{array}{l}13.0 \\
14.9\end{array}$ & $\frac{14.6}{14.4}$ & $\begin{array}{l}1.3 \\
14.3\end{array}$ & 15.2. & $\begin{array}{l}14.5 \\
14.6\end{array}$ & $\begin{array}{l}14.5 \\
14.5\end{array}$ & 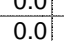 & $\begin{array}{ll}14.6 .6 \\
14.6\end{array}$ & $\begin{array}{l}\frac{16.4}{16.5} \\
\end{array}$ & 0.0 & $\begin{array}{l}\frac{150}{150} \\
15\end{array}$ & 0.0 & $\frac{11.1}{11.7}$ & 0.0 & 0.0 & 0.0 & 0.0 & 0.0 & 0.0 & 0.0 & 0.0 & $\begin{array}{l}0.0 \\
0.0\end{array}$ & $\begin{array}{l}0.0 \\
0.0\end{array}$ \\
\hline 2/22/05 19:30 & 202.91 & $\begin{array}{l}102.04 \\
162.04\end{array}$ & 100.87 & $\begin{array}{l}14.5 \\
14.6\end{array}$ & $\begin{array}{l}\frac{14.5}{14.9} \\
\end{array}$ & $\begin{array}{l}\frac{1.0}{14.6} \\
\end{array}$ & $\begin{array}{l}14.9 \\
14.9\end{array}$ & $\begin{array}{l}14.4 .6 \\
14.6\end{array}$ & $\begin{array}{l}14.5 \\
14.4\end{array}$ & $\begin{array}{l}1.2 .1 \\
15.1\end{array}$ & $\begin{array}{l}14.0 \\
14.5\end{array}$ & $\begin{array}{l}14.5 \\
14.4\end{array}$ & 0.0 & $\begin{array}{l}14.0 \\
14.7 \\
\end{array}$ & $\begin{array}{l}10.5 \\
16.4\end{array}$ & 0.0 & $\begin{array}{ll}15.0 \\
15.0\end{array}$ & 0.0 & $\begin{array}{ll}11.1 \\
11.5\end{array}$ & 0.0 & 0.0 & 0.0 & 0.0 & 0.0 & 0.0 & 0.0 & 0.0 & 0.0 & $\begin{array}{l}0.0 \\
0.0\end{array}$ \\
\hline \begin{tabular}{|l|}
$2 / 22 / 05$ \\
\end{tabular} & 262.91 & 162.09 & 100.82 & 14.3 & 14.7 & 14.7 & 14.3 & 14.6 & 13.8 & 15.0 & 14.3 & 14.5 & 0.0 & 14.4 & 16.4 & 0.0 & 14.7 & 0.0 & 13.7 & 0.0 & 0.0 & 0.0 & 0.0 & 0.0 & 0.0 & 0.0 & 0.0 & 0.0 & 0.0 \\
\hline $\begin{array}{l}0519: 40 \\
10519: 45\end{array}$ & $\begin{array}{l}262.91 \\
26301\end{array}$ & $\begin{array}{l}162.05 \\
16213 \\
\end{array}$ & 100.86 & 14.4 & 14.6 & 14.6 & 14.2 & $\frac{14.5}{14.5}$ & 14.6 & $\begin{array}{ll}15.0 \\
150\end{array}$ & 14.2 & 14.4 & 0.0 & $\frac{14.4}{14.4}$ & 16.4 & 0.0 & $\frac{14.6}{147}$ & 0.0 & 14.2 & 0.0 & 0.0 & 0.0 & 0.0 & 0.0 & 0.0 & 0.0 & 0.0 & 0.0 & 0.0 \\
\hline $\begin{array}{l}2 / 22 / 1 / 5519: 45 \\
2 / 22 / 15 \\
19: 50\end{array}$ & $\begin{array}{l}263.1 \\
262.91 \\
\end{array}$ & $\begin{array}{l}162.13 \\
162.20\end{array}$ & $\begin{array}{l}100.88 \\
100.71\end{array}$ & $\begin{array}{l}\frac{14.4}{14.2} \\
\end{array}$ & & $\begin{array}{l}14.6 \\
14.6\end{array}$ & $\frac{14.2}{14.3}$ & $\begin{array}{l}14.5 \\
14.6 \\
\end{array}$ & $\begin{array}{l}13.7 \\
137\end{array}$ & $\begin{array}{l}15.0 \\
150\end{array}$ & $\begin{array}{ll}14.2 \\
14.3\end{array}$ & $\begin{array}{l}14.4 \\
14.4\end{array}$ & 0.0 & $\begin{array}{l}14.4 \\
14.4\end{array}$ & $\begin{array}{l}16.5 \\
16.4\end{array}$ & 0.0 & $\begin{array}{l}14.7 \\
14 .\end{array}$ & 0.0 & $\begin{array}{l}14.3 \\
146\end{array}$ & 0.0 & 0.0 & 0.0 & 0.0 & 0.0 & 0.0 & 0.0 & 0.0 & 0.0 & $\begin{array}{l}0.0 \\
0.0\end{array}$ \\
\hline $21<\angle T O S 19.50$ & 202.91 & 102.20 & 100.11 & $\begin{array}{l}\frac{14.2}{14.2} \\
\frac{1}{4}\end{array}$ & $\frac{14.5}{14.6}$ & $\frac{14.6}{14.7}$ & $\begin{array}{l}14.3 \\
14.2\end{array}$ & 14.6. & $\begin{array}{l}13.1 \\
14.8\end{array}$ & 15.0 & $\begin{array}{l}\frac{14.3}{15.1} \\
\end{array}$ & $\begin{array}{l}14.4 \\
14.3\end{array}$ & 0.0 & $\begin{array}{ll}14.4 \\
14.3 \\
\end{array}$ & $\begin{array}{l}\frac{16.4}{16.5} \\
\end{array}$ & 0.0 & $\frac{14.6}{14.6}$ & $\begin{array}{l}0.0 \\
0.0\end{array}$ & $\begin{array}{l}14.6 \\
14.6\end{array}$ & $\begin{array}{l}0.0 \\
0.0\end{array}$ & 0.0 & 0.0 & 0.0 & 0.0 & 0.0 & 0.0 & 0.0 & 0.0 & 0.0 \\
\hline $2 / 22 / 0520: 00$ & 263.01 & 162.20 & 31 & $\begin{array}{ll}14.6 \\
14.6\end{array}$ & $\begin{array}{l}\frac{1.0}{14.2} \\
1.2\end{array}$ & $\begin{array}{l}\frac{1}{14.1} \\
14.1\end{array}$ & $\begin{array}{l}14.4 \\
14.3\end{array}$ & $\begin{array}{l}14.4 .3 \\
14.3\end{array}$ & $\begin{array}{l}14.0 \\
14.7\end{array}$ & 15.0 & $\begin{array}{l}13.4 \\
14.4\end{array}$ & $\begin{array}{l}14.5 \\
14.5\end{array}$ & 0.0 & 14.5 & $\begin{array}{l}10.5 \\
16.5\end{array}$ & 0.0 & $\begin{array}{l}14.0 \\
14.6\end{array}$ & 0.0 & $\begin{array}{l}14.0 \\
14.6\end{array}$ & 0.0 & 0.0 & 0.0 & 0.0 & 0.0 & 0.0 & 0.0 & 0.0 & 0.0 & 0.0 \\
\hline 2/22/0520:05 & 263.01 & 162.30 & 100.71 & 14.5 & 14.7. & 14.9 & 14.3 & 14.9 & 14.2 & 15.0 & 13.7. & 14.5 & 0.0 & 14.7. & 16.5 & 0.0 & 14.6 & 0.0 & 14.6 & 0.0 & 0.0 & 0.0 & 0.0 & 0.0 & 0.0 & 0.0 & 0.0 & 0.0 & 0.0 \\
\hline$\frac{2 / 22105}{2 / 22105}$ & $\begin{array}{l}263.01 \\
26301\end{array}$ & $\frac{162.11}{161.98}$ & & $\begin{array}{l}14.4 \\
14.4\end{array}$ & $\begin{array}{l}14.0 \\
140\end{array}$ & $\frac{14.5}{139}$ & 14.3 & $\begin{array}{l}14.9 \\
146\end{array}$ & 14.2 & 15.1 & $\begin{array}{l}15.3 \\
14.3\end{array}$ & $\begin{array}{ll}14.3 \\
143\end{array}$ & 0.0 & $\begin{array}{l}14.8 \\
11.5 \\
-15\end{array}$ & 16.5 & 0.0 & 14.6 & 0.0 & 14.7 & 0.0 & 0.0 & 0.0 & 0.0 & 0.0 & 0.0 & 0.0 & 0.0 & 0.0 & 0.0 \\
\hline $\begin{array}{l}2 / 222105201: 15 \\
2 / 22 / 10520: 20\end{array}$ & $\frac{263.01}{2601}$ & $\begin{array}{l}161.98 \\
16210\end{array}$ & $\begin{array}{l}101.03 \\
100.91\end{array}$ & $\frac{14.4}{145}$ & $\begin{array}{l}14.0 \\
14.3\end{array}$ & $\frac{13.9}{14.0}$ & $\frac{14.2}{140}$ & $\begin{array}{l}14.6 \\
1147\end{array}$ & $\frac{14.2}{14.3}$ & 14.6 & $\frac{14.3}{14.4}$ & $\frac{14.3}{14.4}$ & 0.0 & $\begin{array}{l}14.5 \\
140 \\
10\end{array}$ & $\frac{16.4}{16.5}$ & 0.0 & $\frac{14.6}{14.6}$ & 0.0 & $\begin{array}{ll}14.6 \\
140\end{array}$ & 0.0 & 0.0 & 0.0 & 0.0 & 0.0 & 0.0 & 0.0 & 0.0 & 0.0 & 0.0 \\
\hline 20.20 & & & & $\begin{array}{l}14.5 \\
14.3\end{array}$ & $\frac{14.5}{14.3}$ & $\frac{14.0}{14.5}$ & $\begin{array}{l}14.0 \\
14.0\end{array}$ & $\begin{array}{l}14.7 \\
14.7\end{array}$ & $\begin{array}{l}14.3 \\
14.2\end{array}$ & 14.6 & $\begin{array}{l}14.4 \\
14.5\end{array}$ & $\begin{array}{l}14.4 \\
14.4\end{array}$ & 0.0 & 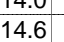 & $\begin{array}{l}10.5 \\
16.6\end{array}$ & . & $\begin{array}{l}1.4 .0 \\
14.6\end{array}$ & 0.0 & $\begin{array}{l}14.0 \\
14.2\end{array}$ & 0.0 & 0.0 & 0.0 & 0.0 & 0.0 & $\begin{array}{l}0.0 \\
0.0\end{array}$ & 0.0 & 0.0 & 0.0 & 0.0 \\
\hline $21 / 2210520: 30$ & 263.07 & 161.84 & 23 & 14.3 & 14.3 & $\begin{array}{l}13.7 \\
13.7 \\
\end{array}$ & $\begin{array}{l}1.4 .0 \\
14.0\end{array}$ & $\begin{array}{l}14.7 \\
14.7 \\
\end{array}$ & $\begin{array}{ll}1.4 .2 \\
14.2\end{array}$ & 14.6 & $\begin{array}{l}14.0 \\
14.4\end{array}$ & 14.3 & 0.0 & 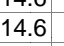 & $\begin{array}{l}10.0 \\
16.2\end{array}$ & 0.0 & $\begin{array}{l}14.0 \\
14.5\end{array}$ & 0.0 & 14.2 .2 & 0.0 & 0.0 & 0.0 & 0.0 & 0.0 & 0.0 & 0.0 & 0.0 & 0.0 & \\
\hline 2/22/05 20:35 & 263.11 & 161.96 & 101.15 & 13.9 & 13.7 & 13.8 & 14.1 & 13.7 & 13.8 & 14.6 & 13.9 & 13.5 & 0.0 & 14.3 & 16.2 & 0.0 & 14.6 & 0.0 & 13.9 & 0.0 & 0.0 & 0.0 & 0.0 & 0.0 & 0.0 & 0.0 & 0.0 & 0.0 & 0.0 \\
\hline 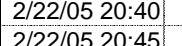 & 263.11 & $\frac{161.80}{161.89}$ & $\begin{array}{l}101.30 \\
101.22\end{array}$ & $\frac{13.9}{137}$ & $\begin{array}{ll}13.6 \\
137\end{array}$ & $\frac{13.7}{13 .}$ & $\begin{array}{l}14.1 \\
14.1\end{array}$ & $\begin{array}{l}13.7 \\
13.5 \\
\end{array}$ & $\frac{13.6}{13.5}$ & $\begin{array}{ll}14.6 \\
11.7\end{array}$ & 14.0 & $\begin{array}{ll}13.4 \\
134\end{array}$ & 0.0 & 13.8 & $\frac{16.4}{16.4}$ & 0.0 & 13.4 13. & 0.0 & $\begin{array}{l}13.9 \\
13.2\end{array}$ & 0.0 & 0.0 & 0.0 & 0.0 & 0.0 & 0.0 & 0.0 & 0.0 & 0.0 & 0.0 \\
\hline 20.45 20.50 & 26. & & $\begin{array}{l}10.122 \\
{ }_{10122}\end{array}$ & 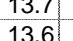 & & $\begin{array}{c}13.8 \\
13.9\end{array}$ & $\begin{array}{l}14.1 \\
14.1\end{array}$ & 13.5 & 年3.5 & $\begin{array}{l}14.1 \\
11.7\end{array}$ & 年14.1 & $\frac{13.4}{13.5}$ & 然. & 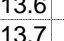 & $\frac{16.4}{163}$ & 0 & 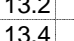 & $\begin{array}{l}0.0 \\
0.0\end{array}$ & 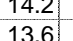 & $\begin{array}{l}0.0 \\
0.0\end{array}$ & 0.0 & 0.0 & $\begin{array}{l}0.0 \\
0.0\end{array}$ & $\begin{array}{l}0.0 \\
0.0\end{array}$ & $\begin{array}{l}0.0 \\
0.0\end{array}$ & 0.0 & & 0.0 & 0.0 \\
\hline $20: 55$ & 263.11 & $\begin{array}{l}161.89 \\
161.79\end{array}$ & $\begin{array}{l}101.22 \\
101.32\end{array}$ & $\begin{array}{l}13.6 \\
13.6\end{array}$ & $\frac{13.5}{13.6}$ & $\frac{13.9}{13.8}$ & $\frac{14.1}{13.8}$ & $\begin{array}{l}13.6 \\
13.5\end{array}$ & $\frac{13.6}{14.2}$ & $\begin{array}{ll}13.7 \\
13.7\end{array}$ & $\begin{array}{l}14.0 \\
14.1\end{array}$ & $\begin{array}{l}13.5 \\
13.4\end{array}$ & 0.0 & 13.6 & $\begin{array}{l}16.3 \\
16.2\end{array}$ & 0.0 & $\begin{array}{l}13.4 \\
13.6\end{array}$ & $\begin{array}{l}0.0 \\
0.0\end{array}$ & $\begin{array}{l}13.6 \\
13.6\end{array}$ & $\begin{array}{l}0.0 \\
0.0\end{array}$ & $\begin{array}{l}0.0 \\
0.0\end{array}$ & $\begin{array}{l}0.0 \\
0.0\end{array}$ & $\begin{array}{l}0.0 \\
0.0\end{array}$ & $\begin{array}{l}0.0 \\
0.0\end{array}$ & 0.0 & 0.0 & $\begin{array}{l}0.0 \\
0.0\end{array}$ & 0.0 & 0.0 \\
\hline 2/22/05 21:00 & 263.11 & 161.67 & 101.44 & 13.7 & 13.6 & $\begin{array}{l}13.6 \\
13.8 \\
\end{array}$ & $\begin{array}{ll}13.0 \\
13.6\end{array}$ & $\begin{array}{ll}13.5 \\
13.5\end{array}$ & $\begin{array}{l}1.4 \\
13.7\end{array}$ & 13.7 & 14.1 & $\begin{array}{l}13.4 \\
13.3 \\
\end{array}$ & 0.0 & 13.6 & 16.2 & 0.0 & $\begin{array}{l}13.0 \\
13.6\end{array}$ & 0.0 & $\begin{array}{l}13.0 \\
13.7 \\
\end{array}$ & 0.0 & 0.0 & 0.0 & 0.0 & 0.0 & 0.0 & 0.0 & 0.0 & 0.0 & 0.0 \\
\hline 21:05 & 263 & & & 13.9 & 13.8 & 13.9 & 13.7 & 13.7 & 14.0 & 13.7 & 14.2 & 14.4 & 0.0 & 14.0 & 16.3 & 0.0 & 13.8 & 0.0 & 13.8 & 0.0 & 0.0 & 0.0 & 0.0 & 0.0 & 0 & 0.0 & 0.0 & 0.0 & 0.0 \\
\hline $21: 10$ & & & & 10.4 & 14.0 & 14.3 & 13.7 & & 14.9 & $\begin{array}{l}14.7 \\
15.7 \\
\end{array}$ & 14.2 & 14 & & 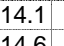 & 3 & & 13.9 & 0. & & 0.0 & 0.0 & 0.0 & 0.0 & 0.0 & & 0.0 & 0.0 & 0 & \\
\hline $\begin{array}{l}21: 15 \\
21: 20 \\
21\end{array}$ & $\begin{array}{l}263.21 \\
263.21 \\
\end{array}$ & $\begin{array}{l}161.68 \\
161.68\end{array}$ & & $\begin{array}{l}0.0 \\
0.0\end{array}$ & $\begin{array}{l}14.5 \\
15.2\end{array}$ & $\begin{array}{l}14.4 \\
15.3\end{array}$ & $\begin{array}{l}\frac{14.7}{15.0} \\
15\end{array}$ & $\begin{array}{l}14.9 \\
11.9\end{array}$ & $\begin{array}{l}\frac{14.7}{15.1} \\
\end{array}$ & $\begin{array}{l}15.2 \\
15.0 \\
-15\end{array}$ & $\begin{array}{l}14.2 \\
15.0\end{array}$ & $\begin{array}{l}14.1 \\
15.0\end{array}$ & $\begin{array}{l}0.0 \\
0.0\end{array}$ & $\begin{array}{ll}14.6 \\
414.9\end{array}$ & $\begin{array}{l}\frac{16.5}{16.2} \\
16 .\end{array}$ & $\begin{array}{l}.0 \\
0\end{array}$ & $\begin{array}{l}14.9 \\
14.9\end{array}$ & $\begin{array}{l}0.0 \\
0.0\end{array}$ & $\begin{array}{l}\frac{14.5}{15 .} \\
15\end{array}$ & $\begin{array}{l}0.0 \\
0.0\end{array}$ & $\begin{array}{l}0.0 \\
0.0\end{array}$ & $\begin{array}{l}0.0 \\
0.0\end{array}$ & $\begin{array}{l}0.0 \\
0.0\end{array}$ & $\begin{array}{l}0.0 \\
0.0\end{array}$ & 0. & 0.0 & $\begin{array}{l}0.0 \\
0.0\end{array}$ & $\begin{array}{l}0.0 \\
0.0\end{array}$ & $\begin{array}{l}0.0 \\
0.0\end{array}$ \\
\hline 25 & & & & 0. & 15.4 & 15.4 & & & 15.0 & 14.8 & 8 & 15.1 & & 15.1. & 2 & & 15 & 0.0 & & & & & 0.0 & 0.0 & & 0.0 & o 0.0 & 0 & \\
\hline 2/22105 21:30 & & & & 0.0 & 15.5 & 15.3 & & 14 & 15.0 & 14.8 & 14.9 & 15. & 0 & 15.0 & 16.1 & 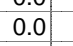 & 14. & 0.0 & 15.2 & 0.0 & 0.0 & 0.0 & 0.0 & 0.0 & 0. & 0.0 & 0.0 & 0.0 & \\
\hline 21:-0 - & & & & & 15.5 & 15.1 & & & 15.0 & 14.9 & 15.1 & 15.2 & & 15.1 & 3 & & 14.7 & 0. & & 0.0 & 0.00 & 0. & 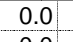 & 0.0 & & 0.0 & 0.0 & 0 & \\
\hline 01.15 & $\begin{array}{l}263.11 \\
26^{2} 311\end{array}$ & & & 0.0 & 13.7 & $\frac{15.1}{14 .}$ & 14.9 & 14 & 15.0 & $\begin{array}{ll}14.9 \\
110\end{array}$ & 15.0 & 14.2 & & $\begin{array}{ll}14.2 \\
11 .\end{array}$ & 16.3 & & 14.6 & 00 & 15.0 & 0 & 0 & 0 & 0.0 & 00 & & 0.0 & 0.0 & 0.0 & 0 \\
\hline $\begin{array}{l}1521.45 \\
521: 50\end{array}$ & 263.11 & $\begin{array}{l}\frac{161.68}{161.48} \\
168\end{array}$ & $\begin{array}{l}101.43 \\
101.63\end{array}$ & 0.0 & $\frac{14.0}{14.4}$ & 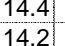 & $\frac{14.5}{14.3}$ & $\frac{14}{14}$ & $\frac{14.6}{14.5}$ & $\begin{array}{l}14.9 \\
14.6 \\
-1\end{array}$ & $\frac{15.0}{15.0}$ & $\frac{14.2}{14.2}$ & 0.0 & 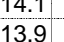 & $\frac{16.1}{16.1}$ & $\frac{0}{0}$ & $\frac{13.9}{14.4}$ & 0.0 & $\frac{15.0}{14.8}$ & $\frac{0.0}{0.0}$ & $\begin{array}{l}0.0 \\
0.0\end{array}$ & $\begin{array}{l}0.0 \\
0.0\end{array}$ & $\frac{0.0}{0.0}$ & 0.0 & & 0 & 0.0 & 0.0 & 0.0 \\
\hline 55 & & & & 0.0 & $\begin{array}{l}1.4 \\
12.9\end{array}$ & $\frac{14.2}{13.3}$ & & $\begin{array}{l}1.4 .4 \\
13.4\end{array}$ & 12.7 & $\begin{array}{l}14.0 \\
13.1\end{array}$ & 12.2 & 12. & & 13.3 & $\frac{10.1}{16.5}$ & 0 & $\begin{array}{ll}1.4 \\
12.4\end{array}$ & $\begin{array}{l}.0 \\
0.0\end{array}$ & 13. & 0. & 0.0 & 0.6 & 0.0 & 0. & & 0.0 & 0.0 & 0.0 & $\begin{array}{l}0.0 \\
0.0\end{array}$ \\
\hline $2 / 22$ & 263.11 & 160 & & 0.0 & 12.4 & 11.8 & 12.3 & 12.1 & 12.0 & $\frac{x 1.8}{11.8}$ & 12.0 & 12.2 & 0.0 & 12.2 & 16.1 & 0.0 & 12. & 0.0 & 11. & 0.0 & 0.0 & $0 . c$ & 0.0 & 0. & & 0.0 & 0.0 & 0.0 & 0 \\
\hline & & & & 0.0 & 0.0 & 12.7 & & 12 & 12.3 & 12.9 & 4 & 12 & & 12.0 & 5.9 & & 12. & 0.0 & 12. & ${ }^{2}$ & 0.0 & 0.0 & 0.0 & 0.0 & & 0.0 & 0.0 & 0.0 & \\
\hline & & & & 0. & 然. & 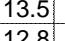 & & 13 & 13. & & & & & 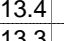 & 0.0 & & 年2 & & & & & 8 & 00 & & & o.. & 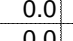 & 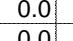 & 0. \\
\hline 竞:2:20 & 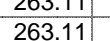 & $\begin{array}{l}166 \\
166\end{array}$ & & $\begin{array}{l}0.0 \\
0.0\end{array}$ & 0.0 & $\begin{array}{l}12.8 \\
12.8\end{array}$ & & & $\begin{array}{l}13.1 \\
12.8\end{array}$ & & & & & 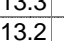 & $\begin{array}{l}0.0 \\
0.0\end{array}$ & & $\frac{1}{12}$ & & & & & 0. & 0.0 & & & $\begin{array}{l}.0 .0 \\
0.0\end{array}$ & 0.0 & 0.0 & \\
\hline $522: 25$ & 263.11 & 16 & & $\begin{array}{l}.0 \\
0.0\end{array}$ & 0.0 & $\frac{1.8}{12.2}$ & $\begin{array}{l}12.8 \\
12.7\end{array}$ & $\begin{array}{ll}12.8 \\
12.7\end{array}$ & $\begin{array}{l}12.8 \\
12.8\end{array}$ & $\begin{array}{l}1.3 .5 \\
13.3\end{array}$ & $\begin{array}{l}12.6 \\
12.6\end{array}$ & $\frac{14}{12}$ & & $\begin{array}{l}13.2 . \\
13.0\end{array}$ & $\begin{array}{l}0.0 \\
0.0\end{array}$ & $\begin{array}{l}0.0 \\
0.0\end{array}$ & $\begin{array}{l}1.2 .9 \\
12.7\end{array}$ & 0. & 12. & 0.0 & 0. & 0. & $\begin{array}{l}0.0 \\
0.0\end{array}$ & b & & 0.0 & $\begin{array}{l}0.0 \\
0.0\end{array}$ & 0.0 & $\begin{array}{l}0.0 \\
0.0\end{array}$ \\
\hline $2 / 2$ & 263 & & & 0. & 0.0 & 12.1 & 12.6 & 12. & 12.6 & 12. & 12.5 & 1 & & 12.3 & 0. & & 12 & 0. & 12.4 & 0. & 0. & 0. & 0.0 & & & 0.0 & 0.0 & 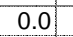 & \\
\hline 年 & & & & . & 0.0 & $\frac{12.0}{1.07}$ & 12.6 & 12.6 & 12.6 & $\frac{12 .}{12}$ & 12.5 & 12 & & $\begin{array}{l}12.3 . \\
120.1\end{array}$ & 0. & & 12. & & 12 & & 0. & $0.6-6>0$ & & & & 0.0 & 0.0 & 0 & 0. \\
\hline 45 & $\begin{array}{r}263.01 \\
26301\end{array}$ & & & 0.0 & 0. & $\begin{array}{l}12.5 \\
120\end{array}$ & & 12 & 12 & & $\begin{array}{l}12.3 \\
124\end{array}$ & & & 12. & 0.8 & & 12 & 0 & & & & 0 & 0 & & & 0.0 & 0.0 & $\begin{array}{l}0 \\
0\end{array}$ & 0.0 \\
\hline CIEZ & $\begin{array}{l}26.301 \\
263.01\end{array}$ & & & 0.0 & 0.0 & $\begin{array}{l}\frac{12.0}{11.9} \\
19\end{array}$ & $\begin{array}{l}12.2 \\
12.1\end{array}$ & $1 \pm>2>$ & 11. & $\frac{11 .}{13 .}$ & & $\begin{array}{l}\frac{12}{12} \\
\frac{1}{1}\end{array}$ & & & 0.6 & & $\frac{12}{12}>20$ & & & & & & & & & 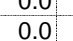 & 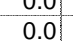 & 0 & 0.4 \\
\hline $2 / 2210522: 55$ & 263 & $15 \div$ & & $\begin{array}{l}0.0 \\
0.0\end{array}$ & 0.0 & $\begin{array}{ll}1.19 \\
11.9\end{array}$ & $\begin{array}{l}1.1 \\
11.9\end{array}$ & $\begin{array}{ll}1.10 \\
11.9\end{array}$ & 2.1 & $\begin{array}{l}13.0 \\
12.0\end{array}$ & $\begin{array}{l}12.0 \\
11.7\end{array}$ & 1 & 0. & 12. & 0.0 & 0.0 & $\frac{12}{11}$ & 0. & $\frac{14}{11}$ & 0. & 0. & 0. & 0.0 & & & 0.0 & 0.0 & 0.0 & 0. \\
\hline $523: 00$ & 26 & & & 0.0 & 0.0 & 13.3 & 12 & 13 & 0.0 & 13 & 0. & & & 12.2 & 0. & 0.0 & 13 & 0. & & & 0. & 0. & & & & 0.0 & 0.0 & b & \\
\hline & & & & 0.0 & 0.0 & 13.4 & 13.3 & & 0. & 13 & . & & & 3. & 0. & & 13 & & & & 0.6 & 0 & R0 & 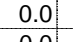 & & 0.0 & 0.0 & 0 & 0. \\
\hline 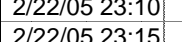 & & & & 0.0 & 0.6 & $\begin{array}{l}13.6 \\
134\end{array}$ & $\begin{array}{l}9.6 \\
00\end{array}$ & & 0 & & 0. & & & 0.6 & 0. & & & & & & & & & & & 0.0 & $\begin{array}{l}0.0 \\
0.0\end{array}$ & 0 & \\
\hline 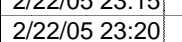 & 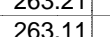 & & & $\begin{array}{l}0.0 \\
0.0\end{array}$ & $\begin{array}{l}0 . \\
0 .\end{array}$ & $\begin{array}{l}1.43 \\
1.42\end{array}$ & $\begin{array}{l}0.0 \\
0.0\end{array}$ & & 0. & 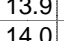 & 0. & & & . & 0. & & $\begin{array}{l}14 \\
14\end{array}$ & & & & & 0 & & & & 0.0 & 0.0 & 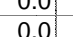 & . \\
\hline$=$ & 263 & $\begin{array}{l}15 \\
15\end{array}$ & & 0.0 & 0. & 1.4. & 0.0 & 13 & 0. & 1.4.1 & 0.0 & 13 & & $0.8 \quad-8$ & 0.0 & 染. 0 & 14 & 0. & 14.3 & $\mathrm{~F}$ & 0. & 0. & 0.0 & 5 & & 0.0 & 0.0 & 0.0 & 0. \\
\hline 23:30 & 26 & 1 & & 0.0 & 0.6 & 14.2 & 0.0 & 1 & 0. & 14 & 0.0 & 13 & & 0. & 0.0 & 0.0 & 14 & $0.6>$ & 14.3 & 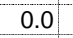 & 0.0 & 0.0 & 5 & 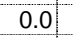 & & 0.0 & 0.0 & 5 & 0 \\
\hline 23:35 & 263 & $\begin{array}{l}159.20 \\
152\end{array}$ & 103 & 0.0 & 0.0 & 14.2 & 0.0 & 13 & 0.0 & 14.1. & 0.0 & $\begin{array}{l}13.6 \\
1.37\end{array}$ & 0. & 0.0 & 0.0 & 0.0 & $\begin{array}{l}14.6 \\
11.6\end{array}$ & 0.0 & $\begin{array}{l}14.1 \\
1.1\end{array}$ & 0.0 & 0.0 & 0.0 & 0.0 & 0.0 & 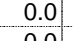 & 0.0 & 0.0 & 0.0 & 0.0 \\
\hline & $\begin{array}{l}263 \\
263\end{array}$ & $\begin{array}{l}159 \\
159\end{array}$ & & & $\begin{array}{l}0.0 \\
0.00\end{array}$ & $\begin{array}{ll}1.42 \\
1.43\end{array}$ & & 13. & & $\frac{14}{14}$ & & & & 0. & & & 13.8 & & & & $\begin{array}{l}0.0 \\
0.00\end{array}$ & 0.0 & & & & 0 & & & \\
\hline & 20001 & $\begin{array}{l}159.20 \\
159\end{array}$ & $\begin{array}{l}103.85 \\
103.81\end{array}$ & $\begin{array}{l}.0 \\
0.0\end{array}$ & 0.0 & $\begin{array}{l}\frac{14.3}{14.2} \\
\end{array}$ & $\begin{array}{l}.0 \\
0.0\end{array}$ & $\begin{array}{l}\frac{13.8}{13.8}\end{array}$ & $\begin{array}{l}0.0 \\
0.0\end{array}$ & $\begin{array}{l}14 . \\
14.1\end{array}$ & $\begin{array}{l}0.0 \\
0.0\end{array}$ & 13 & $\begin{array}{l}0.0 \\
0.0\end{array}$ & 0.0 & $\begin{array}{l}0.0 \\
0.0\end{array}$ & 0.0 & $\begin{array}{l}13.0 \\
136\end{array}$ & 0. & $\begin{array}{l}14.5 \\
143\end{array}$ & $\begin{array}{l}.0 \\
0.0\end{array}$ & 0.0 & 0. & 0.0 & 0 & & 0.0 & 0.0 & bi & 0 \\
\hline 23:55 & 263.01 & 159.20 & 105.38 & $\begin{array}{l}0.0 \\
0.0\end{array}$ & 0.0 & $\begin{array}{l}13.4 \\
13.9\end{array}$ & 0.0 & $\begin{array}{l}13.0 \\
13.7\end{array}$ & 0.0 & $\begin{array}{l}14.1 \\
14.1\end{array}$ & 0.0 & 13.5 & 0.0 & 0.0 & 0.0 & 0.0 & $\begin{array}{l}1.0 .9 \\
10.9\end{array}$ & 0.0 & $\begin{array}{l}14.5 \\
14.2\end{array}$ & 0.0 & 0.0 & 0.0 & 0.0 & 0.0 & 0.0 & 0.0 & 0.0 & 0.0 & 0.0 \\
\hline
\end{tabular}




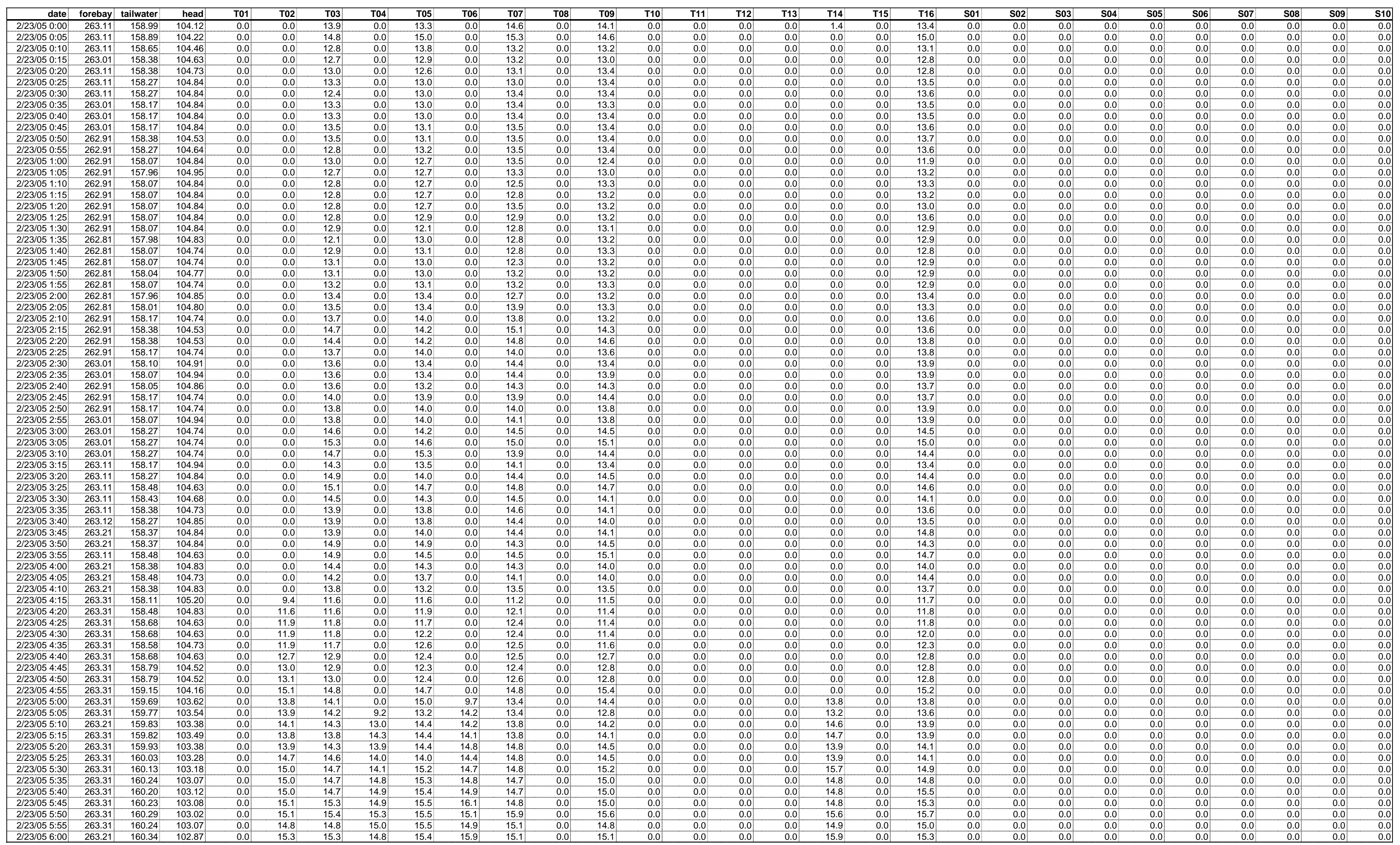




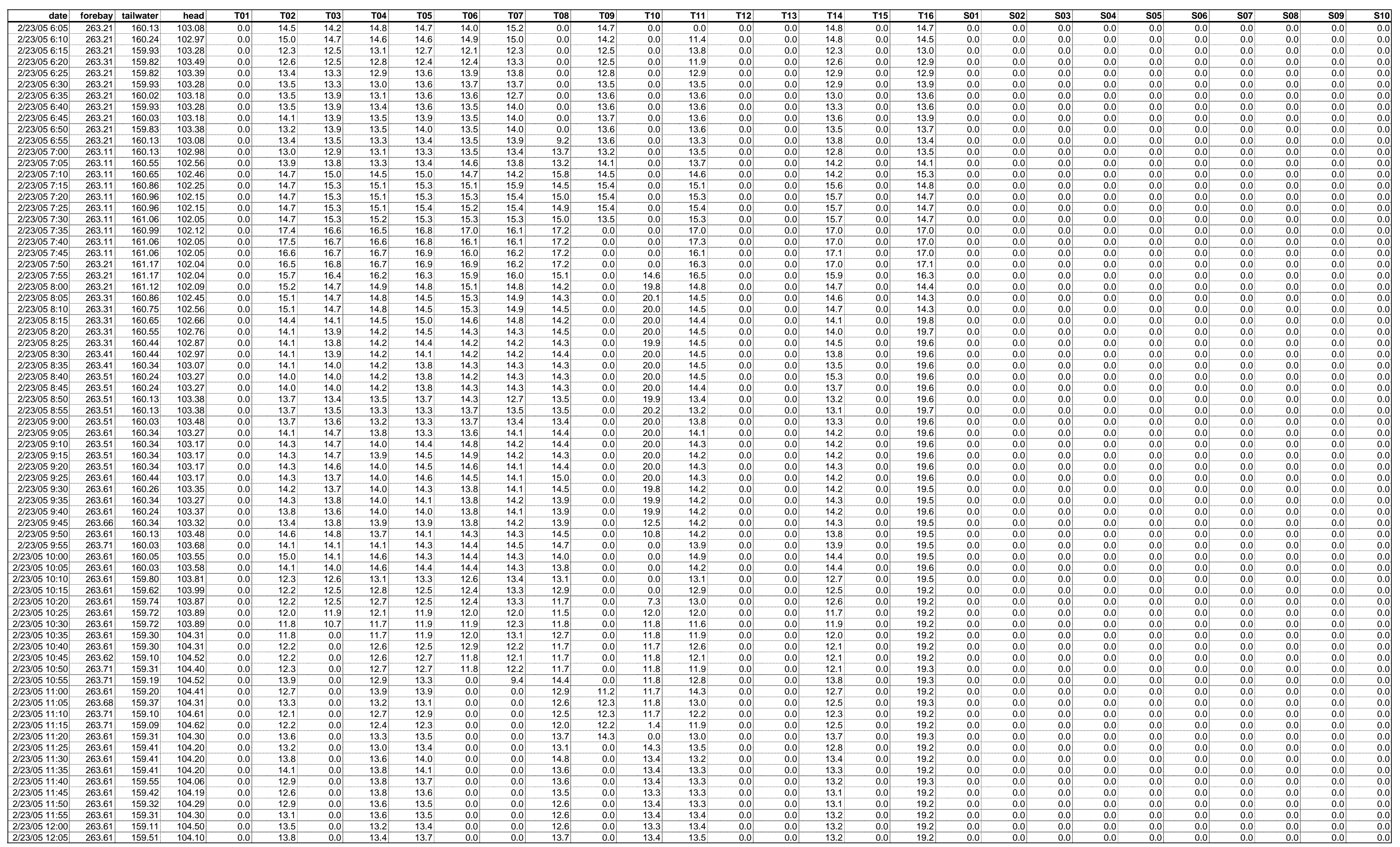




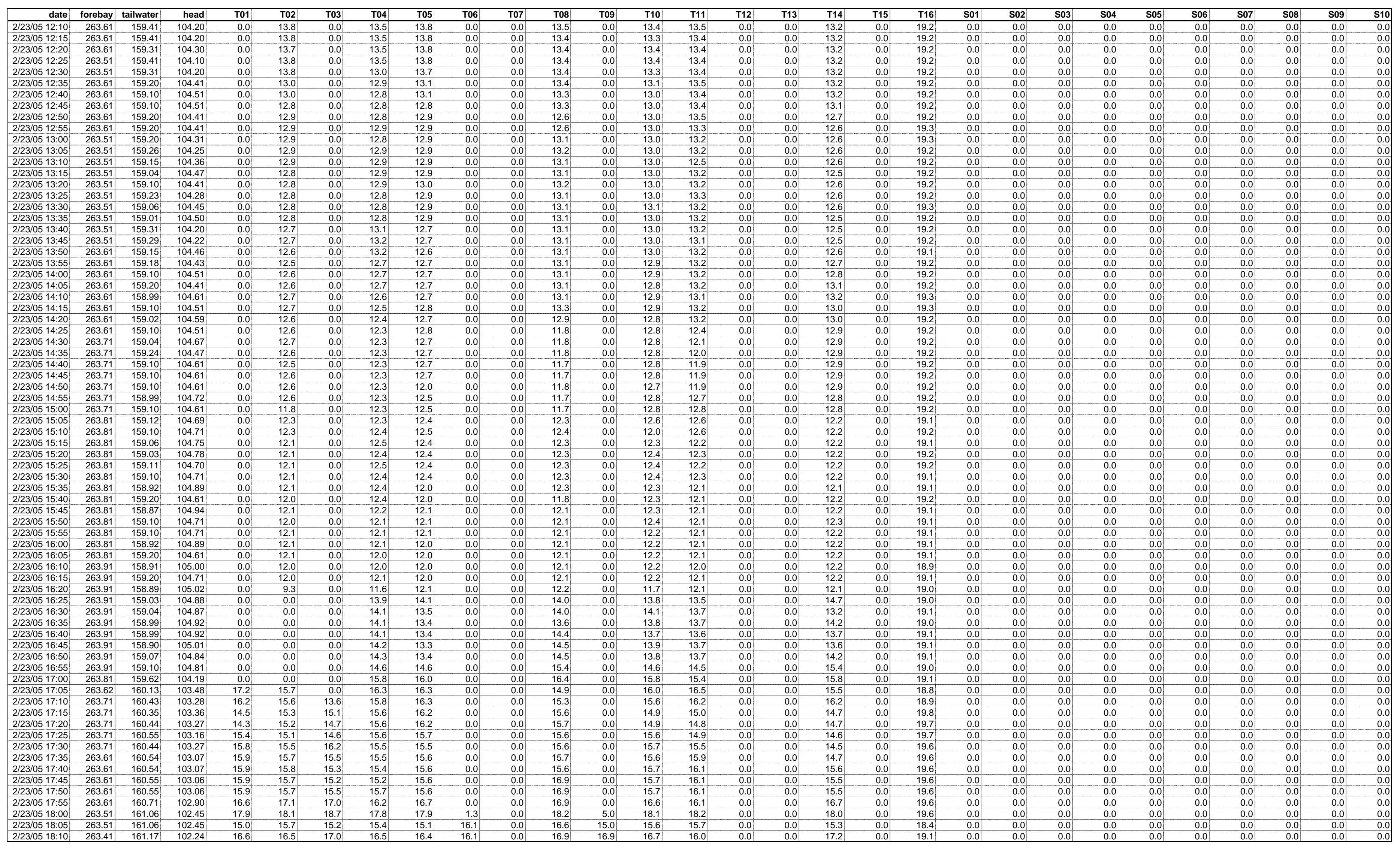




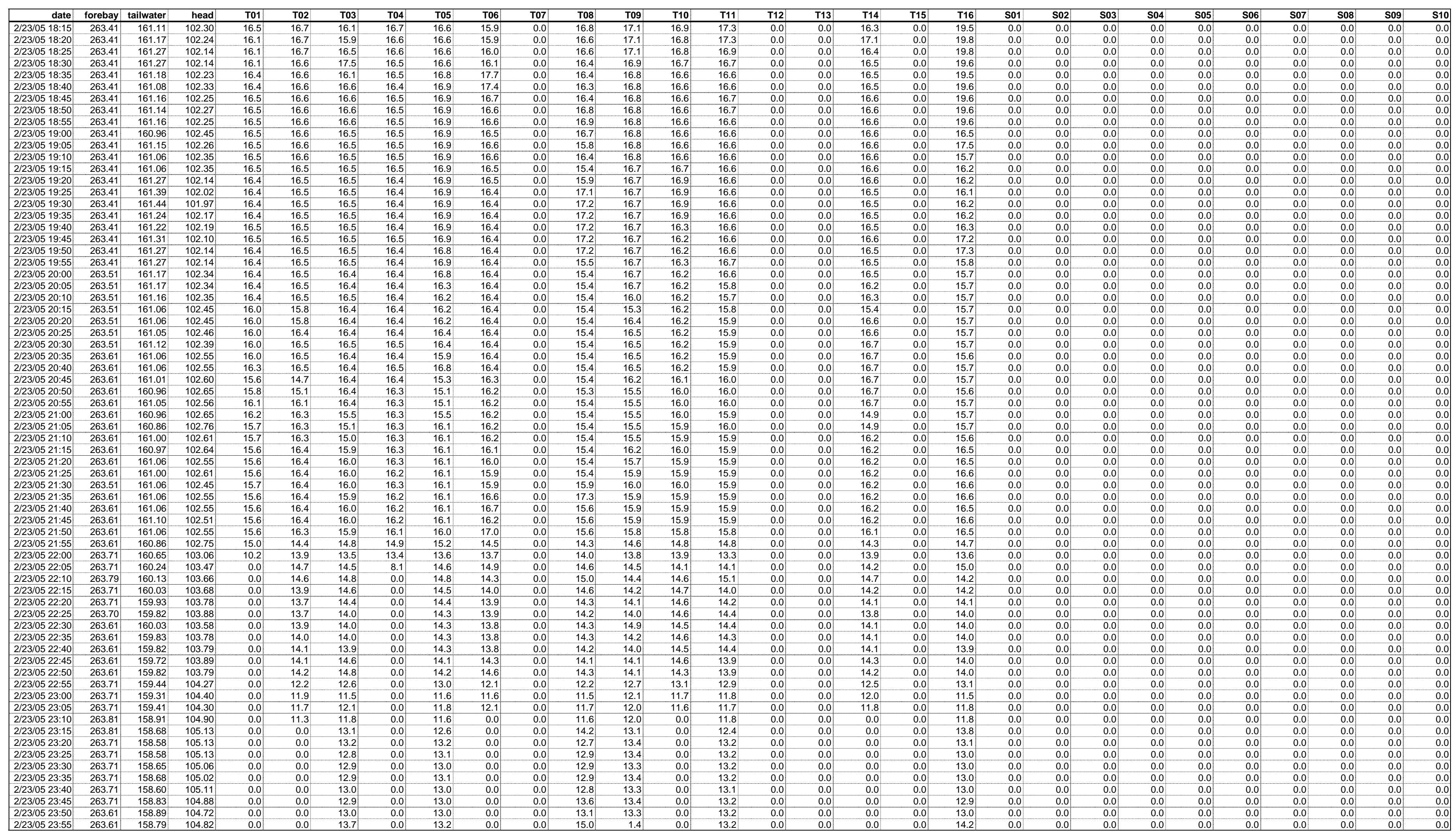




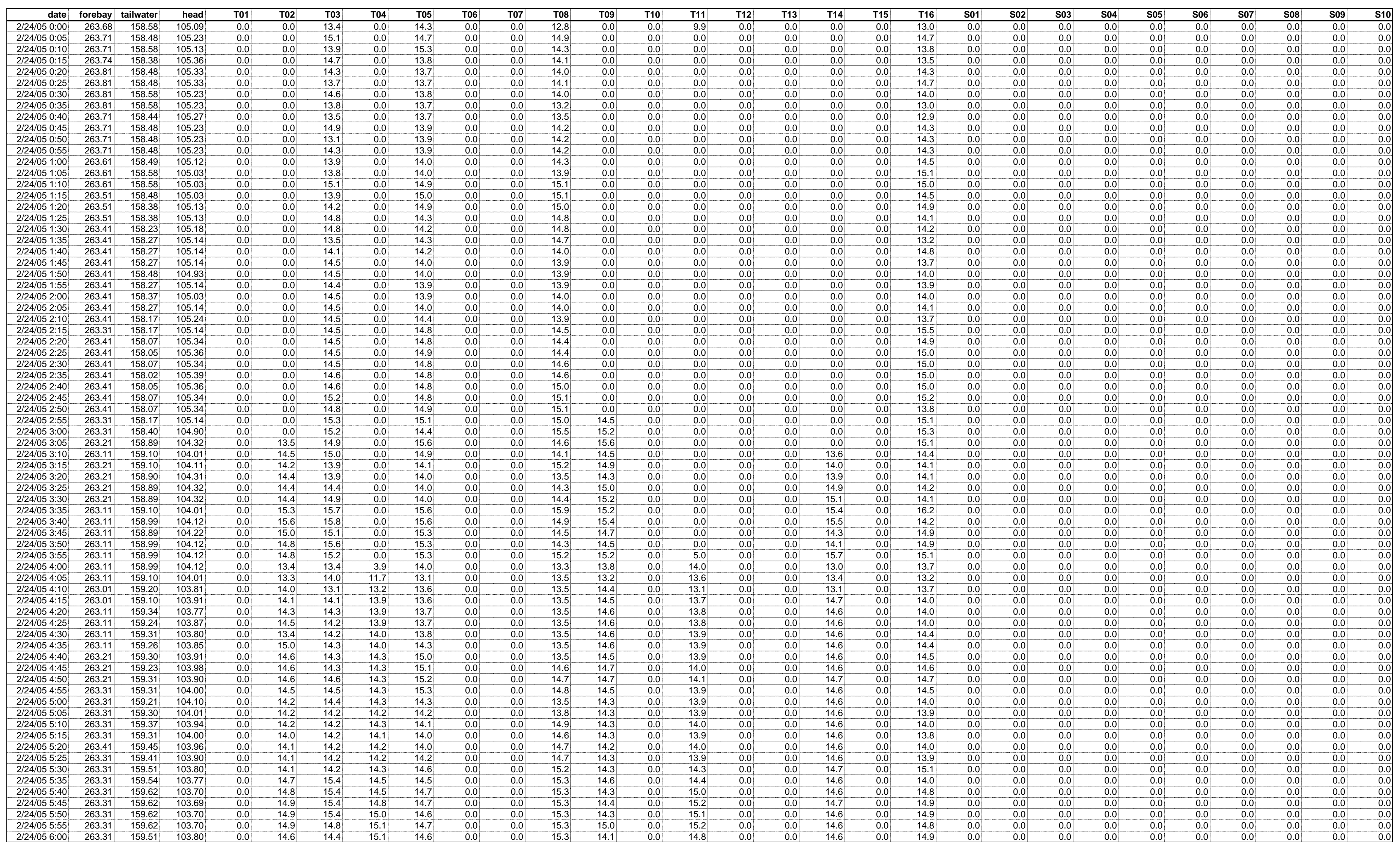




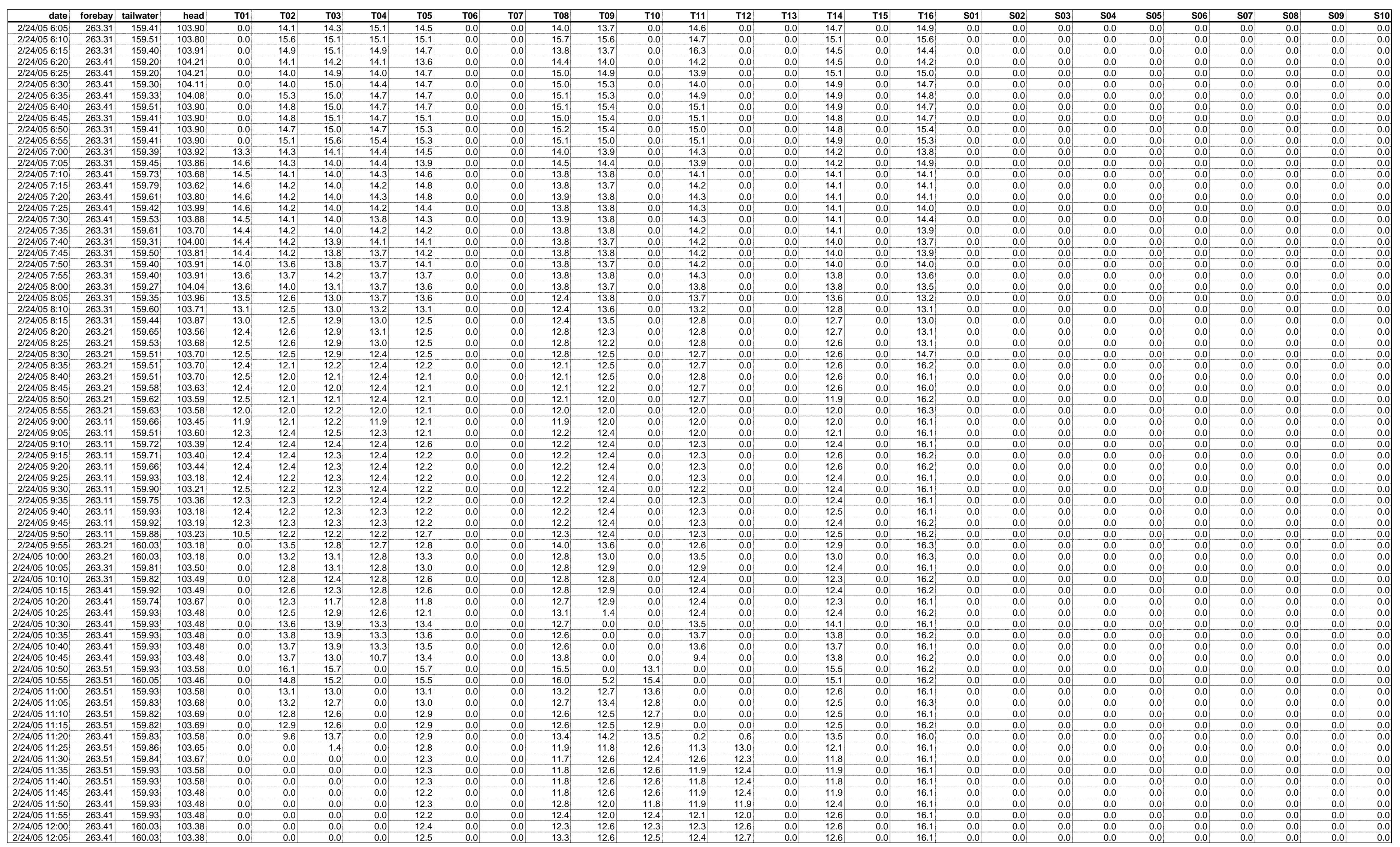




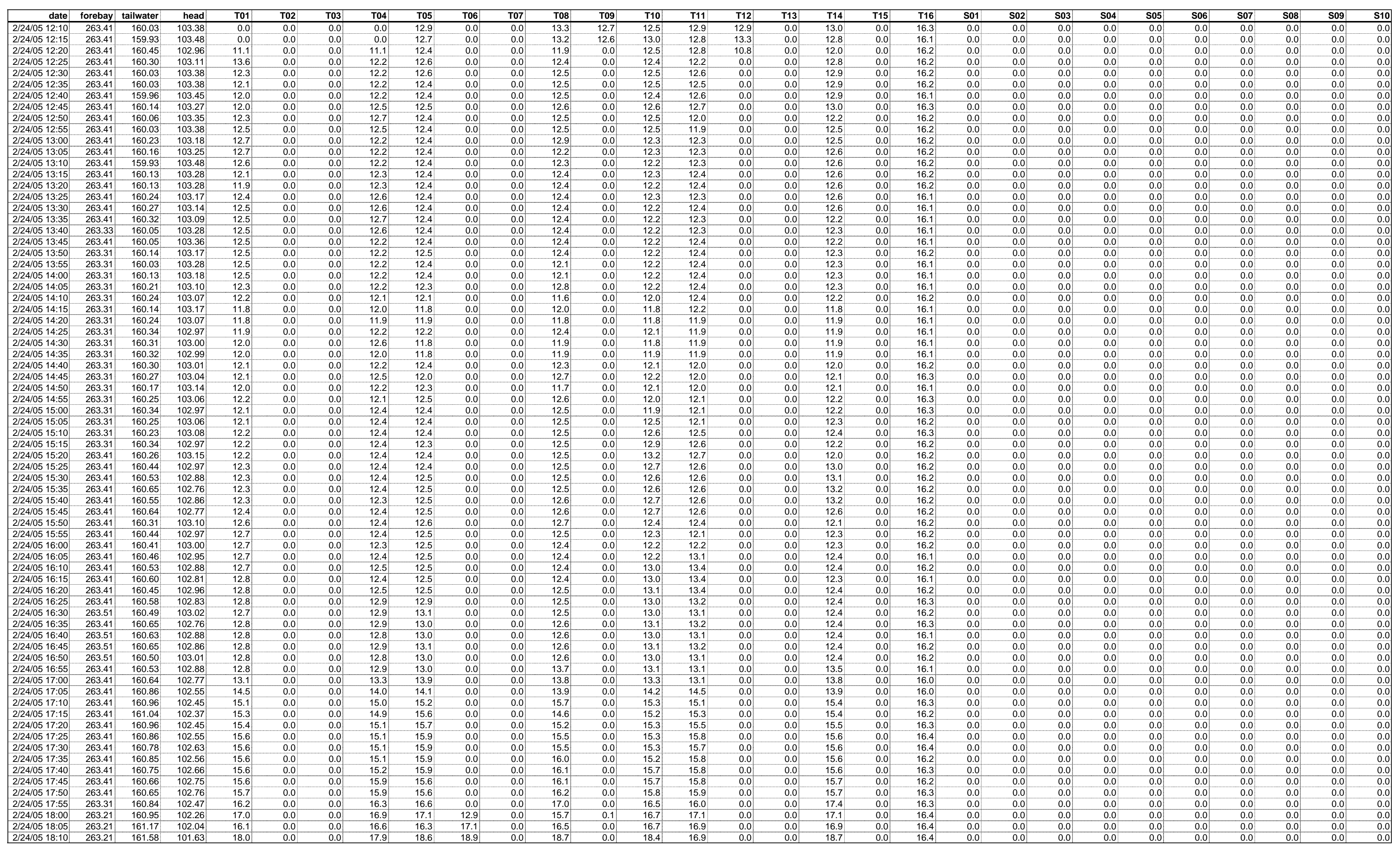




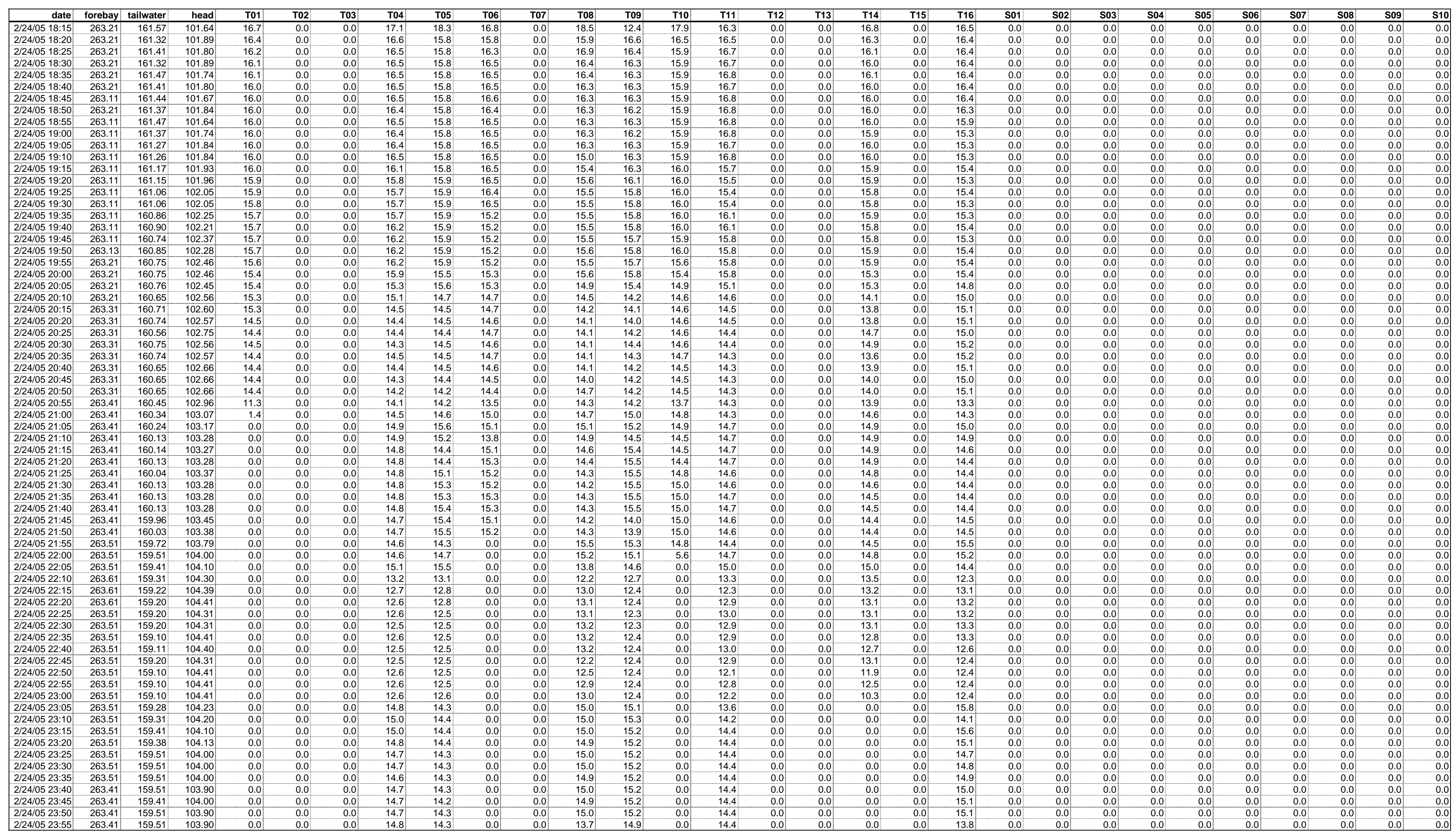

